If you no longer need this publieation write to the Geological Survey in Washington for an official mailing label to use in returning it

UNITED STATES DEPARTMENT OF THE INTERIOR

INDEX TO RIVER SURVEYS MADE BY THE

UNITED STATES GEOLOGICAL SURVEY

AND OTHER AGENCIES

REVISED TO JULY 1, 1947

GEOLOGICAL SURVEY WATER-SUPPLY PAPER 995 

UNITED STATES DEPARTMENT OF THE INTERIOR

J. A. Krug, Secretary GEOLOGICAL SURVEY W. E. Wrather, Director

Water-Supply Paper 995

\title{
INDEX TO RIVER SURVEYS MADE BY THF. UNITED STATES GEOLOGICAL SURVEY AND OTHER AGENCIES
}

\author{
REVISED TO JULY 1, 1947
}

BY

BENJAMIN E. JONES and RANDOLPH O. HELLAND

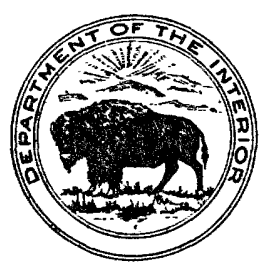

UNITED STATES

GOVERNMENT PRINTING OFFICE

WASHINGTON : 1948

F. $r$ sale by the Superintendent of Documents, U. S. Government Printing Office, Washingtu⿰ 25, D. C. Price 75 cents 



\section{CONTENTS}

Introduction

Alabama_.

Alaska _..

Arizona_ - 2 -

Arkansas.

California

Colorado

Connecticut_ -

Delaware

District of Columbia.

Florida

Georgia $\ldots \ldots$

Hawaii

Idaho

Illinois. 2 - .

Indiana

Iowa. - .

Kansas_.

Kentucky _.

Louisiana...

Maine

Maryland....

Massachusetts_...

Michigan.....

Minnesota..........

Mississippi

Missouri

Montana.

Nebraska.

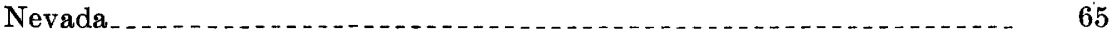

New Hampshire

New Jersey

New Mexico . . .

New York

North Carolina

North Dakota

Ohio

Oklahoma

Oregon

Pennsylvania

Rhode Island. .

South Carolina

South Dakota

Tennessee...... 98 
Texas

Utah.

Vermont

Virginia

Washington

West Virginia

Wisconsin

Wyoming

Index

\section{ILLUSTRATIONS}

Plate 1. Map showing areas covered by topographic surveys made by the

Page Geological Survey prior to July 1, 1947

In pocket 2. Map of the United States showing drainage areas and index numbers

In pocket 


\title{
INDEX TO RIVER SURVEYS MADE BY THE UNITED STATES GEOLOGICAL SURVEY AND OTHER AGENCIES
}

\author{
Revised to July 1, 1947
}

By Benjamin E. Jones and Randolph O. Helland

\section{INTRODUCTION}

The descriptive list of surveys of rivers in the United States issued by the United States Geological Survey in 1926 as Water-Supply Paper 558 comprised surveys by the Geological Survey and other Federal bureaus and by State, semiofficial, and private agencies. Since then many additional river surveys, most of them now available in published sheets, have been completed by the Geological Survey, and four supplemental lists describing them have been issued in mimeographed form. The first supplement was compiled by B. E. Jones in 1934, the second by R. O. Helland and D. M. Paul in 1938, the third by R. O. Helland in 1940, and the fourth by L. L. Young and N. J. Tubbs in 1944. The present compilation adds to the preliminary index the material issued in the supplements and later information concerning revisions and availability of maps.

This compilation substantially completes the record of river surveys by the Geological Survey prior to July 1, 1947, but it is not intended as a complete index of those made by other agencies. Outstanding among such are the Corps of Engineers of the United States Army, the Bureau of Reclamation of the Department of the Interior, and a number of State agencies.

Many States have assembled and published valuable information on streams and lakes within their boundaries; their contour maps were prepared on various scales and in varying detail. Information concerning maps published by a State agency can usually be obtained by applying to the State engineer.

River surveys by the Geological Survey consist essentially of a planetable traverse of the stream, the topography adjacent to the stream channel being depicted by contour lines. Topography is sketched in the field and is based on altitudes and distances obtained by the alidade and stadia rod. Except in earlier river surveys, topography is generally carried to an elevation sufficiently high above the water surface 
to include the area of proposed reservoir sites, possible canal or conduit locations, and other structures relating to water utilization. The standard scales of river surveys are 1:31,680 and 1:24,000 and the contour intervals in general use are 20 feet on land and 5 feet on water. Surveys made by the United States Geological Survey are usually published by this agency, only a very few having been published by other agencies. All of the maps described in this index have been published by the United States Geological Survey unless otherwise stated in the description of the map.

Most of the river surveys of the Geological Survey are now available in printed sheets 22 by 28 inches, currently priced at 10 cents each. Not all are available, however, as the stock of a map may be exhausted at any time, and reprints are not always made. But if the printed sheet is not obtainable, a photostatic reproduction or blueprint can usually be secured, though the cost of reproduction is higher than the cost of the printed sheet. Any of the maps described may be seen at the main office of the Geological Survey, Federal Works Building, Eighteenth and F Streets NW., Washington, D. C., and many of them at branch offices in the States in which the surveys were made.

Many of the rivers and smaller streams which have not been surveyed independently are shown on the standard topographic maps of the Geological Survey in sufficient detail to afford much valuable information. The areas covered prior to July 1, 1947, and the scale employed for each area, are shown on plate 1.

Inquiries regarding availability of maps should be addressed to the Director, United States Geological Survey, Department of the Interior, Washington 25, D. C.

In this compilation the surveys have been arranged by States, and within the States by drainage basins. Tributary streams are indicated by letters. A stream marked " $(a)$ " is tributary to the lastnamed stream not marked with a letter; a stream marked " $(b)$ " is tributary to the last-named stream marked " $(a)$ ", and so on. In the Great Basin, tributaries of Great Salt Lake and of other independent drainage systems are indicated by " $(a) . "$

The index number made up of letters and figures in parentheses refers to the drainage-area subdivisions shown on plate 2. The numbers refer to the major areas that form the great drainage basins of the country, as classified by the Geological Survey in its publications on stream flow and by the Weather Bureau in its meteorologic reports. These basins are as follows:

1. North Atlantic.

2. South Atlantic and eastern Gulf of Mexico.

3. Ohio River.

4. St. Lawrence River.

5. Upper Mississippi River and Hudson Bay.

6. Missouri River. 
7. Lower Mississippi River.

8. Western Gulf of Mexico.

9. Colorado River.

10. Great Basin.

11. Pacific basins in California.

12. North Pacific.

Each major area is divided into intermediate areas conforming to its dominant drainage systems and designated 12A, 12B, etc., the number indicating the major area, the letter referring to a specific intermediate area within it. Intermediate areas are further divided into minor areas, each designated by the number of the major area, the letter of the intermediate area, and a final letter distinguishing it from adjacent minor areas, as 12FA, 12FB. Each drainage division is lettered in order from the upper reaches of the basin to the lower.

The scale of the maps described is given in the form of a ratio; for example, the ratio $1: 31,680$ indicates that a linear foot on the printed map represents 31,680 linear feet of surveyed distance. Other equivalents for the various scales in common use by map-making agencies are given in the table below.

The height to which topography is shown is usually noted; unless otherwise stated, this is the height above the water surface.

Dam sites are listed immediately below the name of the river or lake on which they are located.

Ratios for customary map scales a

\begin{tabular}{|c|c|c|c|c|c|c|}
\hline Scale 1 to- & $\begin{array}{l}\text { Inches per } \\
\text { mile }\end{array}$ & $\begin{array}{l}\text { Inches per } \\
1,000 \text { feet }\end{array}$ & $\begin{array}{l}\text { Miles per } \\
\text { inch }\end{array}$ & $\begin{array}{l}\text { Feet } \text { per } \\
\text { inch }\end{array}$ & $\begin{array}{l}\text { Meters per } \\
\text { inch }\end{array}$ & $\begin{array}{l}\text { Feet per } \\
1 / 50 \text { ineh }\end{array}$ \\
\hline $\begin{array}{r}600 \\
1,200 \\
2,400 \\
2,500 \\
4,800 \\
5,280 \\
610,000 \\
12,000 \\
15,000 \\
615,840 \\
620,000 \\
21,120 \\
c 31,680 \\
45,000 \\
48,000 \\
d 62,500 \\
63,360 \\
90,000 \\
96,000 \\
d 125,000 \\
126,720 \\
192,000 \\
250,000 \\
253,440 \\
380,160 \\
500,000 \\
506,880 \\
1,000,000\end{array}$ & $\begin{array}{c}105.60 \\
52.80 \\
26.40 \\
25.344 \\
13.20 \\
12.000 \\
6.336 \\
5.280 \\
4.224 \\
4.0000 \\
3.168 \\
3.000 \\
2.000 \\
1.408 \\
1.320 \\
1.014 \\
1.000 \\
.7040 \\
.6600 \\
.5069 \\
.5000 \\
.3300 \\
.2534 \\
.2500 \\
.1667 \\
.1267 \\
.1250 \\
.06336\end{array}$ & $\begin{array}{c}20.000 \\
10.000 \\
5.000 \\
4.800 \\
2.500 \\
2.273 \\
1.200 \\
1.000 \\
.800 \\
.758 \\
.600 \\
.5682 \\
.3788 \\
.2667 \\
.2500 \\
.1920 \\
.1894 \\
.1333 \\
.1250 \\
.0960 \\
.0947 \\
.0625 \\
.0480 \\
.0473 \\
.0316 \\
.0240 \\
.02368 \\
.0120\end{array}$ & $\begin{array}{c}0.00947 \\
.01894 \\
.03788 \\
.03946 \\
.07576 \\
.08333 \\
.15783 \\
.18939 \\
.23674 \\
.2500 \\
.31566 \\
.33333 \\
.50000 \\
.71023 \\
.75758 \\
.98643 \\
1.00000 \\
1.4205 \\
1.5152 \\
1.9729 \\
2.0000 \\
3.0303 \\
3.9457 \\
4.000 \\
6.000 \\
7.8914 \\
8.0000 \\
15.783\end{array}$ & $\begin{array}{c}50 \\
.100 \\
200 \\
208.3 \\
400 \\
440 \\
833.3 \\
1,000 . \\
.1,250 \\
1,320 \\
1.667 \\
1,760 \\
2,640 \\
3,750 \\
4,000 \\
5,208.3 \\
5,280 \\
7,500 \\
8,000 \\
10,416.7 \\
10,560 \\
16,000 \\
20,833.3 \\
21,120.0 \\
31,680.0 \\
41,666.7 \\
42,240 \\
83,333.3\end{array}$ & $\begin{array}{r}15.24 \\
30.48 \\
60.96 \\
63.50 \\
121.9 \\
134.1 \\
254.0 \\
304.8 \\
381.0 \\
402.3 \\
508 \\
536.4 \\
804.7 \\
1,143.0 \\
1,219.2 \\
1,587.5 \\
1,609.3 \\
2,286.0 \\
2,438.4 \\
3,175.0 \\
3,218.7 \\
4,876.9 \\
6,350.0 \\
6,437.4 \\
9,656.1 \\
12,700 \\
12,875 \\
25,400\end{array}$ & $\begin{array}{r}1.0 \\
2.0 \\
4.0 \\
4.2 \\
8.0 \\
8.8 \\
16.7 \\
20.0 \\
25.0 \\
26.4 \\
33.3 \\
35.2 \\
52.8 \\
75.0 \\
80.0 \\
104.2 \\
105.6 \\
150.0 \\
160.0 \\
208.3 \\
211.2 \\
320.0 \\
416.7 \\
422.4 \\
633.6 \\
833.3 \\
844.8 \\
1,666.7\end{array}$ \\
\hline
\end{tabular}

- From U. S. Geological Survey Bull. 650, 1916.

1:10,000 and 1:20,000 are basic scales used by the Corps of Engineers, U. S. Army.

- $1: 15,840$ and $1: 31,680$ are basic scales used by the General Land Office. 1:31,680 is also used by the

U. S. Geological Survey on standard topographic maps and river-survey maps.

d 1:62,500 and 1:125,000 are subdivisions of 1:1,000,000 used by the U. S. Geological Survey on topographic maps. 


\section{ALABAMA}

Chattahoochee River. See Georgia.

Coosa Rrves ( upper Mobile River) from Curry's Island to Broken Arrow Creek, 19 miles (2VM). Plan and profile by Corps of Engineers, United States Army. Small tracing shows plan of river. No topography. Profile shows section between Wetumpka and Greensport. Scale, 13 inches $=1$ mile. Elevations in WaterSupply Paper 107.

Coosa River. from Wetumpka to Greensport, 142 miles (2VM, 2VN, 2VO). Profile by Corps of Engineers, United States Army. Shows banks and bed of river, and locks. Scale, 1.3 inches $=1$ mile. Elevations in Water-Supply Paper 107.

Alabama River (continuation of Coosa River) (2V).

(a) Tallapoosa River from Tallapoosa, Ga., to Matilda, Ala., 115 miles in Alabama and 3 miles in Georgia (2VA, 2VC). Plan and profile, 1904. Plan is straight-line projection showing bridges, tributaries, and other features by relative distance along river. Scale, $1: 12,000$; and $1: 24,000$. No topography. Published as supplement to Water-Supply Paper 204. Out of stock.

(a) Tallapoosa River from Griffin Shoals in T. 23 N., R. 24 E., to Milstead in sec. 13, T. 17 N., R. 21 E., 64 miles (2VC, 2 VD). Plan and profile, 1901. Scale, $1: 253,000$. No topography, very little detail. Not published.

(b) Big Sandy Creek from mouth 12 miles upstream to point near Dadeville (2VC). Surveyed by Corps of Engineers, United States Army. Table of elevations published in report, Water powers of Alabama, by Alabama Geological Surves, 1916.

(a) Cahaba River from mouth to Shelby County, 108 miles (2WE, 2WD). Profile by Corps of Engineers, United States Army, 1874. Shows elevation of bed of stream and water surface. Scale, 2.5 inches=1 mile. Elevations in Watersupply Paper 107.

(a) Tombigbee River (2X).

(b) Black Warrior River from Tuscaloosa to Sipsey Fork and Mulberry Fork, 92 miles (XN, 2XO, 2XL). Profile by Corps of Engineers, United States Army, probably before 1900. Scale, 2.5 inches $=1$ mile. Shows river bed and water surface. Elevations in Water-Supply Paper 107.

Mississippi RIVER Basin (3).

(a) Ohio River (3V).

(b) Tennessee River from sec. 23, T. 3 S., R. 11 W., to sec. 11, T. 2 S., R. 15 W. (3VM, 3VN). Surveyed, 1924. Scale, 1:24,000. Contour interval, 5 feet. Topography to 55 feet. 5 sheets, covering parts of topographic maps of Muscle Shoals, Ioka, and Gravelly Springs quadrangles. Not published.

For report by Chief of Engineers, United States Army, on the Tennessee River and tributaries in North Carolina, Tennessee, Alabama, and Kentucky, covering navigation, flood control, power development, and irrigation, see 71st Cong., $2 \mathrm{~d}$ sess., H. Doc. 328.

For areas in Alabama covered by United States Geological Survey standard topographic maps see plate 1 .

\section{ALASKA}

During the last 50 years the Geological Survey, in connection with the investigation of mineral resources, has topographically mapped approximately half of Alaska on reconnaissance standards. For special investigations and urgent needs of the Territory some inch to the mile mapping has been undertaken but such surveys covered only about 5,000 square miles in scattered small areas of interest. With the strategic importance which Alaska assumed during the last decade, map requirements of the War Department were such that military per- 
sonnel have mapped about 12,000. square miles during that time. These surveys, published at scales ranging from $1: 20,000$ to $1: 62,500$, mainly covered the Aleutian Islands and an extensive area in the vicinity of Anchorage and the Matanuska Valley.

A cooperative reconnaissance mapping program was undertaken by the Army Air Forces, in collaboration with the Geological Survey, to meet the urgent requirements of the terrain data for aerenautical pilotage charts. During the period from 1942 to 1945, the Army Air Forces covered all unmapped and much of the poorly mapped areas of Alaska with trimetrogon aerial photography. This data was compiled into maps for 1:1,000,000 scale publication in aeronautical charts by the Geological Survey. Generalized data, such as can be presented on these scales is therefore now available for all of Alaska. Basic compilation records, as well as the vertical and the oblique aerial photographs are available for important needs through appropriate channels of the Geological Survey and Army Air Forces respectively.

A coordinated map series, $1: 250,000$ scale, is now planned. The previous accomplishments of the Geological survey, which are now published on sale editions of varying size and shape, will be republished in the future on sheets of standard size and format and henceforth blank areas will be "filled" with the data prepared for aeronautical charts, or from new surveys as they are accomplished. On most of the reconnaissance topographic surveys 200-foot contours have been shown. The data compiled for publication on $1: 1,000,000$-scale areonautical charts, however, showed only thousand-foot form lines since basic field data for a smaller contour interval was not available. The planimetric delineations in these charts, however, are highly detailed since the basic compilation scale and the scale of the aerial photography were relatively large.

Eklutina Lake (14). Plan, United States Geological Survey and Anchorage Public Utilities, 1947. Scale, 1:12,000. Contour interval, 10 feet. Topography to 80 feet. Also underwater contour 68 feet below surface. Published in 3 sheets, 1 showing dam site and creek, 1948 .

Eklutna Creek from Eklutna Lake downstream 4 miles (14). Plan, United States Geological Survey and Anchorage Public Utilities, 1947. Scale, 1:24,000. Contour interval, 20 feet. Published on 1 sheet of Eklutna Lake map, 1948.

Eklutina Lake dam site at outlet of Eklutna Lake. Plan, United States Geological Survey and Anchorage Public Utilities, 1947. Scale, 1:4,800. Contour interval, 10 feet. Topography to 100 feet. Published on 1 sheet of Eklutna Lake map, 1948.

\section{ARIZONA}

Colorado River from Lees Ferry, Ariz., to mouth of Green River in Utah, 28 miles in Arizona and 188 miles in Utah (9FA, 9FC, 9FE). Plan and profile, 1921. Scale, 1:31,680. Contour interval, 20 feet on land, 5 feet on water. Topography detailed. Section in Arizona shown on 3 sheets ( 2 plan, 1 profile), in set of 22 (16 plan, 6 profile). Published in 1922.

Colorado River from Black Canyon, Arizona-Nevada, to Lees Ferry, 356 miles (9FE, 9HA, 9HC, 9LA, 9LB, 9LC). Plan and profile, United States Geological Survey and United States Bureau of Reclamation, 1903, 1919-20, and 1923. Scale, 1:31,680. Contour interval, 50 feet on land, 5 feet on water. Topography detailed. Published in 1924 in 21 sheets (14 plan, 7 profile) by United States Geological Survey.

LAKE MEAD, including Colorado River from Boulder dam in T. 30 N., R. 23 W., to T. 27 N., R. 10 W., Arizona, and Virgin River from the mouth to T. 14 S., R. 69 Æ., Nevada. Plan by Fairchild Aerial Surveys, Inc., for Soil Conservation Serv- 
ice, 1935. Scale, 1:12,000. Contour interval, 5 and 10 feet. Topography to 750 feet. Limited edition published in $\mathbf{5 2}$ sheets by Soil Conservation Service.

Colorado River from international boundary to Black Canyon, Arizona-Nevada, 352 miles (9LA, 9LB, 9LC). Plan and profile based on surveys in 1902-3 and 1920. Scale, $1: 31,680$. Contour interval, 10 and 50 feet on land, 5 feet on water. Topography detailed. Published in 20 sheets (19 plan, 1 profile). Out of stock.

Colorado RIver. Dam sites on Colorado River, wholly or partly in Arizona. Scale of most of the original maps, 1:4,800. Mileage references, except two Glen Canyon sites, are to distance below Lees Ferry. Published in Water-Supply Paper 556.

Glen Canyon dam site No. 2, at 9.6 miles above Lees Ferry. Contour interval, 100 feet. Topography to 900 feet.

Glen Canyon dam site No. 1, at 4 miles above Lees Ferry. Contour interval, 100 feet. Topography to 900 feet.

Marble Gorge bridge site, at mile 5. Contour interval, 20 feet. Topography to 400 feet.

Marble Gorge power site, alternate dam site No. 1 (Redwall), at mile 29.0. Contour interval, 50 feet. Topography to 300 feet.

Marble Gorge power site, Redwall dam site, at mile 30.0. Contour interval, 10 feet. Topography to 250 feet.

Marble Gorge power site, alternate dam site No. 2 (Redwall), at mile 32.2. Contour interval, 50 feet. Topography to 1,150 feet.

Mineral Canyon dam site, at mile 77.8. Contour interval, 20 feet. Topography to 480 feet.

Clear Creek dam site, at mile 84.4. Contour interval, 50 feet. Topography to 1,000 feet.

Granite Wall dam site, at mile 85.1. Contour interval, 50 feet. Topography to 1,000 feet.

Cremation dam site, at mile 86.3. Contour interval, 20 feet. Topography to 580 feet.

Pipe Creek dam site, at mile 88.9. Contour interval, 10 and 50 feet, Topography to 500 feet.

Ruby Canyon dam site, at mile 103.9. Contour interval, 10 feet. Topography to 250 feet.

Hakatai dam site, at mile 110.7. Contour interval, 10 feet. Topography to 250 feet.

Big Bend dam site, at mile 113.3. Contour interval, 20 feet. Topography to 280 feet.

Specter Chasm dam site, at mile 130.0. Contour interval, 50 feet. Topography to 500 feet.

Havasu dam site, at mile 156.6 Contour interval, 20 feet. Topography to 320 feet.

Prospect dam site, at mile 190.1. Contour interval, 50 feet and $\mathbf{1 0}$ feet. Topography to 220 feet.

Diamond Creek dam sites, at miles 225.5 and 225.9. Contour interval, 50 feet. Topography to 700 feet.

Travertine Canyon dam site, at mile 228.6. Contour interval, 50 feet. Topography to 950 feet.

Bridge Canyon dam site, at mile 236.3. Contour interval, 50 feet. Topography to 800 feet.

Spencer Canyon dam site, at mile 246.2. Contour interval, 50 feet. Topography to 700 feet.

Devils Slide dam site, at mile 255.6. Contour interval, 20 feet. Topography to $\mathbf{5 0 0}$ feet. 
Flour Sack Rapids power site, at mile 266. Cross section at dam site.

Pierces Ferry dam site, at mile 277.3 . Contour interval, 10 feet. Topography to 200 feet.

Grand Wash Canyon dam site, at mile 284.2. Contour interval, 50 feet. Topography to 330 feet.

Hualpai Rapids power site, at mile 301.6. Contour interval, 20 feet. Topography to 300 feet.

Virgin Canyon power site, at mile 304.7. Contour interval, 50 feet. Topography to 400 feet.

Boulder Canyon dam site, at mile 334.0. Contour interval, 10 and 50 feet. Underwater contour interval, 25 feet. Topography to.650 feet.

Callville dam site, at mile 311.8. Contour interval, 50 feet. Topography to 250 feet.

Upper Black Canyon dam site, at mile 354.6. Contour interval, 50 feet, Underwater contour interval, 25 feet. Topography to 600 feet.

Middle Black Canyon dam site, at mile 364.9. Contour interval 50 feet. Topography to 300 feet.

Lower Black Canyon dam site, at mile 373.9. Contour interval, 20 feet. Topography to 300 feet.

Eldorado dam site, at mile 377.1. Contour interval, 10 feet. Topography to 160 feet.

Eagle Rock dam site, at mile 397. Contour interval, 10 feet. Topography to 150 feet.

Bulls Head dam site, at mile 421. Contour interval, 10 feet. Topography to 140 feet.

Mohave Canyon flood-control dam site. Elevation at water surface, 427 feet. Contour interval, 10 feet. Topography to 250 feet.

Parker diversion dam site, at mile 524. Contour interval, 25 feet. Topography to 100 feet.

(a) West Canyon Creek from Utah-Arizona line to 3,900-foot contour, 6 miles (9FE). Plan, 1921. Scale, 1:31,680. Contour interval, 20 feet. Topography to 300 feet. Surveyed from mouth in Utah to 3,900-foot contour in Arizona. Shown on parts of two sheets, Colorado River map.

(a) Navajo Creek from mouth to 3,900-foot contour, 30 miles (9FE). Plan, 1921. Scale, $1: 31,680$. Contour interval, 20 feet. Topography detailed. Shown on parts of two sheets, Colorado River map.

(b) Kaibito Creek from mouth to 3,900-foot contour, 6 miles (9FE). Plan, 1921. Scale, 1:31,680. Contour interval, 20 feet. Topography detailed.

(a) Wahweap Creek from mouth to Arizona-Utah line, 5 miles (9FE). Plan, 1921. Scale, $1: 31,680$. Contour interval, 20 feet. Topography detailed. Surveyed from mouth in Arizona to 3,900-foot contour in Utah. Shown on parts of two sheets, 1921 survey of Colorado River.

(a) Paria River from mouth upstream 7 miles (9FE). Plan, 1923. Scale, 1:31,680. Contour interval, 50 feet. Topography to 150-300 feet. Shown on part of one sheet, 1923 survey of Colorado River.

(a) Little Folorado River from point 10 miles northwest of Tolchico to point in T. 11 N., R. 28 E., about 250 miles (9JE, 9JC, 9JA). Plan, 1931-39. Scale, 1:31,680. Contour interval, 10 and 20 feet on land, 5 feet on water. Dam-site scale, 1:4,800; contour interval, 10 feet. Topography detailed. Published in 16 plan sheets, of which 4 show dam sites, and 2 sheets of dam sites, 1948.

Holbrook dam site, in sec. 14, T. 17 N., R. 21 E. Topography to 100 feet. Woodruffs dam site, in sec. 36 , T. 17 N., R. 21 E. Topography to 90 feet. The Forks dam site, in sec. 19, T. 16 N., R. 22 E. Topography to 100 feet. Greer dam site, in sec. 5, T. 14 N., R. 25 E. Topography to 100 feet. 
Little Colorado dam site, in secs. 20 and 21, T. 14 N., R. 27 E. Topography to 100 feet.

(a) Little Colorado River from mouth to Tolchico dam site, 103 miles (9JE). Plan and prufle, 1926. Scale, 1:31,680. Contour interval, 25 feet on land, 5 feet on water. Topography detailed. Published in five sheets (three plan, two profile), 1927.

Tolchico dam site, near Tolchico. Topography to 130 feet.

(b) Zuni River from mouth to point about 6 miles upstream (9JA). Shown on 1934-39 survey of Little Colorado River.

Lower Zuni dam site, near mouth of Zuni River. Scale, 1: 4,800. Topography to 150 feet.

(b) Rio Puerco from mouth to Pinta, sec. 36, T. 20 N., R. 25 E., about 50 miles (9JB). Shown on 1934-39 survey of Little Colorado River.

(c) Black Creek from mouth sec. 26, T. 22 N., R. 29 E., to mile 20 (9JB). Plan and profile, 1937. Scale, 1:24,000. Contour interval, 10 feet on land, 2 feet on water. Topography detailed. Published two sheets, one plan, one profile.

(b) Leroux Wash from mouth to Wide Ruin Wash, T. 21 N., R. 23 E., about 35 miles (9JC). Shown on 1934-39 survey of Little Colorado River.

Leroux Wash dam site, on Leroux Wash near mouth in sec. 25, T. 18 N., R. 20 E. Scale, 1:4,800. Topography to 125 feet. Shown on 1934-39 survey of Little Colorado River.

(b) Cottonwood Wash from mouth to sec. 23, T. 21 N., R. 20 E., about 35 miles (9JE). Shown on 1934-39 survey of Little Colorado River.

(a) Little Colorado River from mouth upstream 5 miles (9JE). Plan, 1903 and 1923. Scale, $1: 31,680$. Contour interval, 50 feet. Topography to $150-350$ feet. Shown on part of one sheet, 1923 survey of Colorado River.

(a) Bright Angel Creek from mouth upstream 2 miles (9HA). Plan, 1903 and 1923. Scale, 1: 31,680. Contour interval, 50 feet. Topography to 50-500 feet. Shown on part of one sheet, 1923 survey of Colorado River.

(a) Shinumo Creek from mouth upstream 3 miles (9HA). Plan, 1905 and 1923. Seale, 1:31,680. Contour interval, 50 feet. Topography to 50-700 feet. Shown on part of one sheet, 1923 survey of Colorado River.

(a) Tapeats Creek from mouth upstream 3 miles (9HA). Plan, 1921 and 1923. Scale, $1: 31,680$. Contour interval, 50 feet. Topography to 50-800 feet. Shown on part of one sheet, 1923 survey of Colorado River.

(a) Kanab Creek from mouth upstream 2 miles (9HB). Plan, 1905, 1921, and 1923. Scale, 1:31,680. Contour interval, 50 feet. Topography to 50-1,000 feet. Shown on part of one sheet, 1923 survey of Colorado River.

(a) Havasu Creek from mouth to sec. 11, T. 33 N., R. 4 W., 6 miles (9HC). Plan, 1921 and 1923. Scale, $1: 31,680$. Contour interval, 50 feet. Topography to $50-1,200$ feet. Shown on part of one sheet, 1923 survey of Colorado River.

(a) Williams River and tributaries from point 8 miles above mouth, 38 miles (9LD), including parts of Santa Maria and Big Sandy River's. Plan and profile, 1933-34. Scale, 1:31,680. Contour interval, 20 feet on land, 5 feet on water. Topography detailed. Published in nine sheets (four plan, four profile, one dam site), 1936.

(a) Williams River from mouth to 500-foot contour, 9 miles (9LD). Plan and profile based on surveys in 1902-3. Scale, 1:31,680. Contour interval, 10 feet. Topography to 10-100 feet. Shown on 1902-3 and 1920 surveys of Colorado River from international boundary to Black Canyon. Out of stock.

Dam site, at mile 30.1 in sec. 9 , T. 10 N., R. 13 W. Scale, $1: 4,800$. Contour interval, 10 feet on land, 5 feet on water. Topography to 470 feet. 
(b) Big Sandy River from mouth to point about 10 miles upstream (9LD). Shown on two sheets (one plan, one profile), 1933-34 survey of Williams River and tributaries.

(b) Santa Maria River from mouth to Kirkland Creek, 50 miles (9LD). Shown on five sheets (three plan, two profile), 1933-34 survey of Williams River and tributaries.

(c) Kirkland Creek from mouth to Skull Valley Wash, 22 miles (9LD), and dam sites. Dam-site scale, 1:4,800; contour interval, 10 feet. Shown on three sheets (one plan, two profile), 1933-34 survey of Williams River and tributaries.

Dam site, at mile 93.5 in sec. 36 , T. 14 N., R. 7 W. Topography to 230 feet.

Dam site, at mile 95.2 in sec. 6 , T. 13 N., R. 6 W. Topography to 200 feet.

Dam site, at mile 105.1 in sec. 20 , T. 13 N., R. 5 W. Topography to 240 feet.

Dam site, at mile 105.6 in sec. 21 , T. 13 N., R. 5 W. Topography to 80 feet.

(a) Gila River from Florence, Ariz., to point in sec. 20, T. 19 S., R. 20 W., New Mexico (9ME, 9MC, 9MA), connecting with lower end of 1915 survey of Gila River in New Mexico (published in Water-Supply Paper 396), and from upper end of 1915 survey to point 6 miles above confluence with West Fork Gila River, N. Mex.; total length about 270 river miles, of which about 200 are in Arizona and 70 in New Mexico. Surveyed as follows: about $1 / 2$ of total river mileage surveyed by United States Office of Indian Affairs, 1913-15, and 1932; a short section surveyed by United States Geological Survey, 1896 ; the remainder surreyed by United States Geological Survey, 1934-35. Surveys by Geological Survey are at scale $1: 31,680$, contour interval, 20 feet on land, 5 feet on water. Topography detailed. Surveys by United States Office of Indian Affairs are larger scale, reduced to 1:31,680 for publication with United States Geological Survey maps. In preparation.

(a) Gila River from mouth of Salt River to east line of T. 4 S., R. 11 E., about 80 miles (9ME). Plan compiled by Corps of Engineers, United States Army. Scale, 1: 126,720. Contour interval, 10 feet. Topography shown in places. Published in report, San Carlos irrigation project, Arizona, by Sixty-third Cong., $2 d$ sess., in House Document 791.

(a) Gila River from mouth of Agua Fria River in sec. 33, T. 1 N., R. 1 W., to T. 3 S., R. 5 E., about 50 miles (9ME). Plan by United States Bureau of Reclamation, 1903-4. Scale, 1:31,680. Contour interval, 5 and 10 feet to 1,350 feet; 50 feet above 1,350 feet. Topography detailed. Shown on three sheets, 190:-3 survey of Salt River (reclamation project).

(a) Gila River, Ariz. Dam sites. Scale, 1:4,800, except as noted. Contour interval, 10 feet, except as noted. Shown on 1934-35 survey of Gila River. In preparation.

Guthrie dam site, approximately in sec. 29 , T. 6 S., R. 30 E. Topography to 340 feet.

Camelback dam site, approximately in sec. 2, T. 6 S., R. 28 E. Scale, $1: 12,000$. Topography to 210 feet.

Needles Eye dam site, in sec. 27, 34. T. 2 S., R. 17 E. Contour interval, 20 feet. Topography to 350 feet.

Mescal dam site, in sec. 29, T. 3 S., R. 17 E. Topography to 340 feet.

Riverside dam site, in sec. 11, T. 4 S., R. 13 E. Topography to 600 feet.

The Buttes dam site, in sec. 11, T. 4 S., R. $11 \mathrm{E}$. Topography to 300 feet.

(b) San Francisco River in New Mexico and Arizona, from mouth to point near Alma, N. Mex., 77 miles, of which 46 miles is in Arizona (9MB). Plan and 
profile, 1934-35. Scale, 1:31,680. Contour interval, 20 feet on land, 5 feet on water. Topography detailed. Published in four sheets (two plan, two profile), 1939.

(b) Salt River from Roosevelt Reservoir to junction of White and Black Rivers, 93 miles (9NA), including Salt River above Roosevelt Reservoir, Black River to Apache National Forest boundary, White River to mouth of Diamond Creek, East Fork White River to Sevenmile Canyon, and Carrizo dam site. Plan and profile, United States Geological Survey and United States Bureau of Reclamation, 1916-32. Scale, 1:31,680. Contour interval, 20 and 25 feet on land, 5 feet on water. Topography detailed. Published by United States Geological Survey in 10 sheets (five plan, five profile), 1933.

Carrizo dam site, at mile 82.4 above Roosevelt Reservoir and just below mouth of Carrizo Creek (9NA). Plan and cross section, 1932. Scale, $1: 4,800$. Contour interval, 10 feet. Topography to 300 feet.

(b) Salt River from west boundary of San Carlos Indian Reservation to junction of White and Black rivers, 58 miles (9NA). Plan and profile by Office of Indian Affairs, 1913. Scale, 1:24,000. Contour interval, 50 feet. Topography to $150-500$ feet. Three sheets. Not published.

(b) Salt River from sec. 4, T. 3 N., R. 14 E., to San Carlos Indian Reservation, 38 miles (9NA). Plan and profile, 1916. Scale, 1:31,680. Contour interval, 25 feet on land, 5 feet on water. Topography detailed. Not published.

(b) Salt River from mouth to Verde River, 44 miles (9NC). Plan by United States Bureau of Reclamation, 1902-03. Scale, 1:31,680. Contour interval, 5 feet. Topography detailed. Shown on two sheets of topographic map of Salt River reclamation project.

(c) Black River from White River to Milk Creek, White Mountain-Apache Indian Reservation boundary, 92 miles (9NA). Plan and profile by Office of Indian Affairs, 1913. Scale, 1:24,000. Contour interval, 50 feet. Topography to $350-500$ feet. Four sheets. Not published.

(c) Black River from mouth to Graham-Greenlee county line, 95 miles (9NA). Plan and profile, 1931-32. Scale, 1:31,680. Contour interval, 20 feet on land, 5 feet on water. Topography detailed. Shown on four sheets, 1916-32 survey of Salt River and tributaries above Roosevelt Reservoir.

(d) Bonita Creek in Fort Apache Indian Reservation, from mouth upstream 4 miles (9NA). Plan, 1932. Scale, 1:31,680. Contour interval, 20 feet on land, 5 feet on water surface. Topography detailed in lower area, but little shown in upper area. Shown on one sheet of 1916-32 survey of Salt River and tributaries above Roosevelt Reservoir.

(c) White River from mouth to Diamond Creek, 28 miles (9NA). Plan and profile, 1932. Scale, 1:31,680. Contour interval, 20 feet on land, 5 feet on water. Topography detailed. Shown on three sheets of 1916-32 survey of Salt River and tributaries above Roosevelt Reservoir.

(c) White River from Black River to point above Paradise Creek, 58 miles (9NA). Plan and profile by Office of Indian Affairs, 1913. Scale, 1:24,000. Contour interval, 50 feet. Topography to $150-500$ feet. Four sheets. Not published.

(d) North Fork White River from Cottonwood Creek upstream 2 miles (9NA), showing also Black Canyon reservoir site. Plan and profile by Office of Indian Affairs, 1913. Scale, 1:4,800. Contour interval, 10 feet. Topography to 250 feet. One sheet. Not published.

(d) East Fork White River from mouth upstream 16 miles (9NA). Plan and prefile by Office of Indian Affairs, 1913. Scale, 1:24,000. Contour interval, 50 feet. Topography to $\mathbf{1 5 0}$ feet. One sheet. Not published. 
(d) East Fork White River from mouth upstream to sec. 30, T. 5 N., R. 23 E., 21/2 miles (9NA). Plan and profile, 1932. Scale, 1:31,680. Contour interval, 20 feet on land, 5 feet on water. Topography detailed. Shown on two sheets of 1916-32 survey of Salt River and tributaries above Roosevelt Reservoir.

(c) Carrizo Creek from mouth upstream 12 miles (9NA). Plan and profile, 1932. Scale, 1: 31,680. Contour interval, 20 feet. Topography detailed. Shown on one sheet of 1916-32 survey of Salt River and tributaries above Rooseveit Reservoir.

(o) Verde River from sec. 7 , T. 17 N., R. 3 E., to Sycamore Creek in T. 12 N., R. 5 E., 53 miles (9NB). Plan and profile, 1934 and 1936. Scale, 1: 31,680. Contour interval, 20 feet on land, 5 feet on water. Topography to 100-300 feet. Published in three sheets (two plan, one showing Gittings dam site, and one profile), 1939.

(c) Verde River from Tangle Creek to sec. 35, T. 13 N., R. 5 E., 47 miles (9NB). Plan and profile, 1916. Scale, 1:31,680. Contour interval, 25 feet on land, 5 feet on water. Topography to 150-250 feet. Published in three sheets (two plan, one profile), 1917.

(c) Verde River from point 3 miles below Camp Creek to Tangle Creek, 39 miles (9NB). Plan and profile, 1930. Scale, 1:48,000. Contour interval, 20 feet on land, 5 feet on water. Topography detailed. Published in one sheet, 1932.

(c) Verde River from Camp Verde dam sites to mouth. Plan by Salt River Valley Water Users Association. Scale, 1:7,000. Contour interval, 5 feet. Topography detailed. Not published.

Gittings dam site, in sec. $16,17,20,21$, T. 17 N., R. 3 E. Scale, 1:4,800.

Contour interval, 10 feet. Topography to 160 feet. Published 1939.

(d) Beaver Creek from mouth upstream 7 miles (9NB). Shown on 1934-36 survey of Verde River.

For areas in Arizona covered by United State Geological Survey standard topographic maps see plate 1 .

\section{ARKANSAS}

MIssissipp RIVER from source to mouth has been surveyed for navigation and flood control by the Mississippi River Commission at different dates and with varying topographic detail. For copies of maps apply to Mississippi River Commission, St. Louis, Mo.

(a) White River from Richland Creek in sec. 30, T. 17 N., R. 28 W., to MissouriArkansas line in sec. 9, T. 21 N., R. 26 W. (7H). Plan and profile by United States Geological Survey and State of Arkansas, 1909. Scale, 1:24,000. Contour interval, 10 feet on land, 5 feet on water. Topography to 20-350 feet. Published in report, Water Powers of Arkansas, by Arkansas Geological Survey, 1911.

(a) White River from Missouri-Arkansas line in sec. 15, T. 21 N., R. 19 W., to Buffalo, T. 17 N., R. 14 W., 91 miles $(7 \mathrm{H})$. Plan and profile by United States Geological Survey and State of Arkansas, 1909. Scale, 1:24,000. Contour interval, 10 feet on land, 5 feet on water. Topography to 20-180 feet above water surface. Published in Water Powers of Arkansas, by Arkansas Geological Survey, 1911.

(b) Buffalo Fork White River from mouth to sec. 3, T. 15 N., R. 23 W., 130 miles $(7 \mathrm{H})$. Plan and profile by United States Geological Survey and State of Arkansas, 1910. Scale, 1:24,000. Contour interval, 10 feet on land, 5 feet on water. Topography to 20-100 feet. Published in report, Water Powers of Arkansas, by Arkansas Geological Survey, 1911. 
(b) North Fork White River from mouth to sec. 35, T. 20 N., R. 12 W., 18 miles (7H). Plan and profile by United States Geological Survey and State of Arkansas, 1909. Scale, 1:24,000. Contour interval, 10 feet on land, 5 feet on water. Topography to $40-100$ feet. Published in report, Water Powers of Arkansas, by Arkansas Geological Survey, 1911.

(a) Red River (7N).

(b) Ouachita River from point near Hot Springs to T. 1 S., R. 24 W., 57 miles (7P). Plan by Corps of Engineers, United States Army, 1909-10. Scale, 1:63,360. Contour interval, 50 feet. Topography detailed. Map shows section of river through mountains, where dams are possible. Dam site on township line between 1, 2 S., R. 21 W., shown on scale 1:6,400, contour interval 10 feet and topography to 300 feet. Most of course is covered also by map on scale $1: 15,000$, in report published by Sixty-second Congress, second session, in House Document 588 .

For areas in Arkansas covered by United States Geological Survey standard topographic maps see plate 1 .

\section{CALIFORNIA}

Mojave River from sec. 6, T. 7 N., R. 4 W., to sec. 6, T. 2 N., R. 4 W., 35 miles (10NE). Plan by Office of Public Roads, United States Department of Agriculture, and California State Department of Engineering. Scale, 1: $82,200 \quad(0.77$ inch $=1$ mile). Contour interval, 50 feet. Topography shown over wide area for proposed irrigation. Published in report on utilization of Mojave River for irrigation in Victor Valley, California, by California Department of Engineering, in Bulletin 5, 1918.

KERN RIver from point 8 miles above Bakersfield to sec. 9, T. 25 S., R. 33 E., 53 miles (11FC, 11FA, 11FB), and dam sites. Plan and profile, 1934. Scale, 1:31,680. Contour interval, 20 feet on land, 5 feet on water. Topography detailed. Published in seven sheets (three plan, two profile, two dam sites) 1937.

Bakersfield dam site at mile 0.0 in sec. 35,36 , T. 28 S., R. 28 E. Scale, 1:4,800. Contour interval, 10 feet. Topography to 230 feet.

Democrat Springs dam site at mile 21.5 in sec. 6, T. 28 S., R. 31 E. Seale, $1: 2,400$. Contour interval, 10 feet. Topography to 460 feet.

Isabella (main) dam site at mile 41 in sec. 36 , T. 26 S., R. 32 E. Scale $1: 2,400$. Contour interval, 10 feet. Topography to 300 feet above water surface, or to 2,700 feet above sea level.

Isabella (auxiliary) dam site, about mile 42.2 in sec. 30, T. 26 S., R. $33 \mathrm{E}$., Scale, 1: 4,800. Contour interval, 5 feet. Topography to 2,700 feet above sea level.

(a) South Fork Kern River from mouth to sec. 7, T. 26 S., R. 35 E., 13 miles (11FB). Shown on two sheets (one plan, one profile) 1934 survey of Kern River.

Carson Lake (10C).

(a) Carson River and tributaries, Nevada and California, from sec. 4, T. 15 N., R. 21 E., Nevada, upstream including West Fork to sec. 6, T. 10 N., R. 19 E., California, and East Fork and tributaries to sec. 28, T. 8 N., R. 21 E., California (10CB, 10CA). Plan and profile by United States Geological Survey in cooperation with United States Bureau of Reclamation, 1934-36. Scale, 1: $\mathbf{3 1 , 6 8 0 .}$ Contour interval, 20 feet on land, 5 feet on water. Topography detailed. Largescale surveys of 13 dam sites. Published in 10 sheets $(5$ plan, 3 profile, and 2 dam sites), 1944. 
(b) West Fork Carson River from California-Nevada boundary to sec. 6, T. 10 N., R. 19 E., 17 miles (10CA). Shown on 1934-36 survey of Carson River and tributaries.

Hope Valley dam site, at mile 25.0 in sec. 25, T. 11 N., R. 18 E. Surveyed

by United States Bureau of Reclamation, 1903. Scale, 1:2,400. Contour interval 5 feet. Topography to 130 feet.

(b) East Fork Carson River from Nevada-California boundary to sec. 28, T. 8 N., R. 21 E., 32 miles (10CA), and dam sites. Dam-site scale 1:4,800, contour interval, 10 feet. Shown on 1934-36 survey of Carson River and tributaries.

Dixon dam site, at mile 68.4 in sec. 28, T. 9 N., R. 21 E. Topography to 150 feet.

Silver King dam site, at mile 71.9 in sec. 2 , T. 8 N., R. 21 E. Topography to 170 feet.

Silver Queen dam site, at mile 74.9 in sec. 11, T. 8 N., R. 21 E. Topography to 120 feet.

Mount Bullion dam site, at mile 61.7 in sec. 36, T. 10 N., R. 20 E. Topography to 250 feet.

Soda Springs dam site, at mile 77.2 in sec. 22 , T. 8 N., R. 21 E. Topography to 110 feet.

Markleeville dam site, at mile 55.4 in sec. 11, T. 10 N., R. 20 E. Topography to 230 feet.

(c) Wolf Creek from mouth upstream 3 miles (10CA). Shown on 1934-36 survey of Carson River and tributaries.

Wolf Creek dam site, at mile 1.1 in sec, 29, T. 9 N., R. 21 E. Scale, $1: 4,800$. Contour interval, 10 feet. Topography to 200 feet.

(c) Pleasant Valley Creek from mouth upstream 5 miles (10CA). Shown on 1934-36 survey of Carson River and tributaries.

Upper Pleasant Valley dam site, at mile 2.7, and Lower Pleasant Valley dam site at mile 2.0. Scale, 1:4,800. Contour interval, 10 feet. Topography to 250 feet.

(c) Heenan Creek from mouth to and including Heenan Lake, 5 miles (10CA). Shown on 1934-36 survey of Carson River and tributaries.

Heenan Lake dam site, at mile 4.1 on Heenan Creek in sec. 3, T. 9 N., R. 21 E. Scale, $1: 2,400$. Contour interval, 5 feet. Topography to 100 feet above natural water surface.

SALTON SEA and vicinity (9LC). Surveyed 1925. Scale, 1: 62,500. Contour interval, 10 feet. Topography 50 feet above water surface which was about 250 feet below sea level. Published in 1 sheet 40 by 40 inches, 1928.

CoLORADo RIVER from international boundary to California-Nevada State line (9LA, 9LB, 9LC). Plan and profile based on surveys in 1902-3 and 1920. Scale, $1: 31,680$. Contour interval, 10 and 50 feet on laud, 5 feet on water. Topography detailed. Published in 20 sheets (19 plan, 1 profile), 1927 . Out of stock.

Cotorado RIVER (9L).

Mojave Canyon dam site, on Colorado River. See Arizona (p. 7).

Parker dam site, on Colorado River. See Arizona (p. 7).

For surveys of Colorado River above California-Nevada State line, see Arizona, Colorado, and Utah.

SAN JoAQUiN RIVER from Friant in sec. 7, T. 11 S., R. 21 E., to forks in T. 5 S., R. $25 \mathrm{E}, 67$ miles (11FG). Plan and profile, 1912. Scale, 1: 31,680. Contour interval, 25 feet on land, 5 feet on water. Topography to 100-150 feet. Published in four sheets by State Water Commission of California, 1914.

SAN Joaquin RIVER from Southern Pacific Railroad crossing in sec. 31, T. 12 S., R. 19 E., to Friant, 19 miles (11FH). Plan, 1916. Scale, 1:31,680. Contour 
interval, 5 feet. Topography to 50-100 feet. Published in two sheets by State Water Commission of California, 1914.

(a) North Fork San Joaquin River from mouth to Iron Creek, 8 miles (11FF). Plan and profile, 1912. Scale, 1:31,680. Contour interval, 25 feet on land, 5 feet on water. Topography to 100-200 feet. Published in one sheet by State Water Commission of California, 1914.

(a) Middle Fork San Joaquin River from mouth to Fish Creek, 14 miles (11FF). Plan and profile, 1912. Scale 1: 31.680. Contour interval, 25 feet on land, 5 feet on water. Topography to $100-400$ feet. Published in two sheets by State Water Commission of California, 1914.

(a) South Fork San Joaquin River from mouth to Blaney Hot Springs, 35 miles (11FF). Plan and profile, 1912. Scale, 1: 31,680. Contour interval, 25 feet on land, 5 feet on water. Topography to 50-100 feet. Published in three sheets by State Water Commission of California, 1914.

(a) Kings River and tributaries from Piedra, sec. 8, T. 13 S., R. 24 E., to sec. 27, T. 12 S., R. 27 E., 32 miles (11FE), including South Fork, Middle Fork, and dam sites. Plan and profile, 1931 and 1936. Scale, 1: 24,000. Contour interval, 20 feet on land, 5 feet on water. Topography detailed. Published in set of six sheets (five plan, one profile).

Pine Flat dam site, at mile 3.6 in sec. 2 , T. 13 S., R. 24 E. Scale, $1: 4,800$. Contour interval, 10 feet. Topography to 635 feet.

Oat Mountain dam sites at mile 17.7 and 18.3 in sec. 22 and 23, T. 12 S., R. 25 E. Scale, 1: 2,400. Contour interval, 5 feet. Topography to 250 feet.

Kellers Ranch dam site, at mile 23.9 in sec. 21 , T. 12 S., R. 26 E. Scale, $1: 2,400$. Contour interval, 5 feet. Topography to 350 feet.

(b) South Fork Kings River fröm sec. 10, T. 13 S., R. 30 E., to sec. 16, T. 13 S., R. $31 \mathrm{E}$., 6 miles (11FE), showing Cedar Grove reservoir site. Scale, 1:12,000. Contour interval, 10 feet on land, 5 feet on water. Topography detailed. Shown on one sheet, 1931-36 survey of Kings River and tributaries.

Cedar Grove dam site, in sec. 10, T. 13 S., R. 30 E. Scale, 1:2,400. Contour interval, 5 feet. Topography to 450 feet.

(b) Middle Fork Kings River in T. 12 S., R. 29 E., from Silver Creek to point 4 miles upstream (11FE), showing Tehipite Valley reservoir site. Scale, 1: 12,000. Contour interval, 10 feet on land, 5 feet on water. Dam-site scale, 1:2,400; contour interval, 5 feet. Shown on one sheet, 1931-36 survey of Kings River and tributaries.

Silver Creek dam site in T. 12 S., R. 29 E. Topography to 600 feet.

Tehipite dam site, in T. 12 S., R. 29 E. Topography to 400 feet.

(a) Tuolumne River from La Grange in sec. 20, T. 3 S., R. 14 E., to sec. 21 , T. 1 N., R. 21 E., 74 miles (11FM, 11FN). Plan and profile, 1899 and 1912. Scale, $1: 31,680$. Contour interval 25 feet on land, 5 feet on water. Topography to 150 feet. Published in six sheets in report by State Water Commission of California, 1912.

(b) Woods Creek from mouth to sec. 2, T. 1 S., R. 14 E., 3 miles (11FN). Plan and profile, 1912. Scale, 1:31,680. Contour interval, 25 feet on land, 5 feet on water. Topography to 25-75 feet. Shown on one sheet, 1899-1912 survey of Tuolumne River. Published in report by State Water Commission of California, 1912.

(a) Stanislaus River from Knights Ferry in sec. 28, T. 1 S., R. 12 E., to Robinson Ferry, in sec. 24, T. 2 N.; R. 13 E., 24 miles (11FP). Plan and profile, 1914. Scale, 1:48,000. Contour interval, 25 feet on land, 5 feet on water. Topography to 150 feet. Published in two sheets, one plan, one profile, 1928 .

(a) Stanislaus River from mouth to junction of Clark Fork and Relief Creek, 128 miles (11FO, 11FP), including Middle Fork. Profile compiled by California 
Power Board, 1922-23. Scale, 1 inch $=111 / 2$ miles for main stream, 1 inch $=7$ miles for Middle Fork. Unpublished map in files of Federal Power Commission.

(a) Middle Fork Stanislaus River (11FO), Beardsley Flat reservoir. Plan by California Power Board, 1922. Scale, 1:25,000. Two contours outlining reservoirs of 30,000 and 60,000 acre-feet capacity. Unpublished map in files of Federal Power Commission.

(a) Stanislaus River at bend 2 miles above Robinson Ferry (11FP), Robinson Ferry dam site. Scale, $1: 3,600$. Contour interval, 10 feet. Topography to 350 feet. Map in files of Federal Power Commission.

(a) Stanislaus River $1 / 4$ mile below mouth of Mormon Creek in sec. 11, T. 1 N., R. 13 E. (11FP). Melones dam site. Plan by California Power Board, 1922. Scale, 1:1,260. Contour interval, 5 feet. Topography to 250 feet. Unpublished map in files of Federal Power Commission.

(a) Stanislaus River, abont 1 mile below mouth of Black Creek in secs. 1, 11, T. 1 S., R. 12 E. (11FP), Black Creek dam site. Plan by California Power Board, 1922. Seale, 1:3,600. Contour interval, 10 feet. Topography to 170 feet. Unpublished map in files of Federal Power Commission.

(b) Relief Creek from mouth upstream 12 miles (11FO). Profile by California Power Board, 1922. Scale, 1 inch $=7$ miles. Unpublished map in files of Federal Power Commission.

(c) East Fork Relief Creek from mouth to source, 11 miles (11FO). Profile compiled by California Power Board, 1922. Scale, 1 inch $=7$ miles. Unpublished map in files of Federal Power Commission.

(b) Clark Fork from mouth upstream 51/2 niles (11FO). Profile by California Power Board, 1922. Scale, 1 inch $=7$ miles. Unpublished map in files of Federal Power Commission.

(b) North Fork Stanislaus River from mouth to Silver Valley, 40 miles (11FO). Profile compiled by California Power Board, 1922. Scale, 1 inch $=7$ miles. Unpublished map in files of Federal Power Commission.

(b) North Fork Stanislaus River in secs. 12, 13, 14, 23, T. 6 N., R. 16 E (11FO). Ramsey reservoir site. Plan by California Power Board, 1922. Scale, 1: 13,300. Contour interval, 10 feet. Topography to 170 feet at dam site. Unpublished map in files of Federal Power Commission.

(c) Highland Creek from mouth upstream, 18 miles (11FO). Profile compiled by California Power Board, 1922. Scale, 1 inch $=7$ miles. Unpublished map in files of Federal Power Commission.

Spicer Meadows dam site, at elevation 6,380 feet. Scale, 1: 1,800. Contour interval, 5 feet. Topography to 60 feet.

(b) South Fork Stanislaus River from mouth to upstream 40 miles (11FO). Profile compiled by California Power Board, 1922. Scale, 1 inch $=7$ miles. Unpublished map in files of Federal Power Commission.

(a) Mokelumne River from Woodridge to sec. 34, T. 5 N., R. 5 E., 14 miles (11DK). Surveyed for navigation; plan and profile by Corps of Engineers, United States Army, 1913. Scale 1: 7,200. Contour interval, 2 feet. Very little topography. Published by Sixty-third Congress, Second session, in House Docu- . ment $\mathbf{1 1 6 0 .}$

Sacramento River from sec. 15 , T. 33 N., R. 5 W., to sec. 27, T. 36 N., R. 5 W., about 25 miles (11BG, 11BA, 11BE, 11BF) and tributaries, showing Shasta (Kennett) reservoir site. Plan, 1933-34. Scale, 1: 12,000. Contour interval, 20 feet on land, 5 feet on water. Topography detailed. Published in 19 sheets ( 2 showing Shasta (Kennett) dam site) 1936.

Shasta (Kennett) dam site, in sec. 15. T. 33 N., R. 5 W. Scale, 1: 1,200. Contour interval 5 and 20 feet on land, 1 foot on water. Topograhpy to 620 feet. 
Sacramento River from Red Bluff to sec. 15, T. 33 N., R. 5 W., 66 miles (11BM, 11BK, 11BG). Plan and profile, 1984-36. Scale, 1:31,680. Contour interval, 20 feet on land, 5 feet on water. Topography detailed. Published in six sheets (three plan, two profile, one showing Keswick dam site), 1938.

Sacramento RIver from sec. 27, T. 28 N., R. 3 W., to sec. 15, T. 29 N., R. 3 W., 20 miles (11BM), showing Iron Canyon reseroir site. Plan, 1904. Scale, 1:24,000. Contour interval, 25 feet. Topography to 25-75 feet. Not published.

SACRAMENTo RIVER from mouth of Feather River to Chico Landing, near Chico, 120 miles (11BN, 11BP). Plan and profile by Corps of Engineers, United States Army, 1909. Profile extends from Sacramento to Chico Landing. Survey for navigation, soundings at frequent intervals. Scale, 1:4,800. Contour interval, 2 feet. Published in 30 sheets in report entitled "Sacramento River, Calif., from Sacramento to Red Bluff" by Sixty-second Congress, First session, in House Document 76.

Keswick dam site, in sec. 17, T. 32 N., R. 5 W. Scale, 1:1,200. Contour interval, 5 feet on land, 1 foot on water. Topography to 190 feet.

(a) Salt Creek from mouth to Fall Creek, sec. 27, T. 35 N., R. 4 W., 5 miles (11BA). Shown on 1833-34 survey of Sacramento River and tributaries.

(a) O'Brien Creek from mouth to sec. 9, T. 34 N., R. 4 W., 4 miles (11BA). Shown on 1933-34 survey of Sacramento River and tributaries.

(a) Pit River from sec. 9, T. 41 N., R. 9 E., to sec. 14, T. 42 N., R. 11 E., 25 miles (11BD), showing Warm Springs Valley reserroir site. Plan by United States Bureau of Reclamation, 1908. Scale, 1:31,680. Contour interval, 10 feet. Topography to 60 feet. Not published.

(a) Pit River from sec. 27 , T. 37 N., R. 7 E., to sec. 28 , T. 41 N., R. 8 E., 40 iniles (11BD), Big Valley reservoir site. Plan by United States Bureau of Reclamation, 1904. Scale, 1:31,680. Contour interral, 10 feet. Topography to 90 feet. Published map scale, 1:126,720; contour interval 20 feet. Published in report by State Water Commission of California, 1912.

Big Valley dam site in T. 37 N., R. 7 E. Scale, 1:1,200. Contour interval, 5 feet. Topography to 100 feet. Not published.

(a) Pit Rirer from mouth to sec. 22, T. 37 N., R. 7 E., 123 miles (11BD, 11BE). Plan and profile, 1912. Scale, 1:31,680. Contour interva1, 25 feet on land, 5 feet. on water. Topography to 100 feet. Published in 8 sheets in report by state Water Commission of California, 1912.

(a) Pit River and tributaries from mouth to sec. 22, T. 35 N., R. 1 W., about 30 miles (11BE). Shown on 1933-34 survey of Sacramento River and tributaries.

(b) South Fork Pit River from sec. 10, T. 39 N., R. 14 E., to sec. 1, T. 39 N., R. 14 E., 3 miles (11BC), Jess Valley reservoir site. Plan by United States Bureau of Reclamation. Scale $1: 34,600$ (1.04 inches $=3.000$ feet $)$. Contour interval, 10 feet. Topography to 100 feet at dam site. Published in report on Pit River Basin, by United States Bureau of Reclamation and State of California, 1915.

Jess Valley dam site. Scale, $1: 6,830$.

(b) Ash Creek from sec. 21, T. 39 N., R. 9 E., to sec. 2 , T. 39 N., R. 9 E., 4 miles (11BD), Round Valley reservoir site. Plan by United States Geological Survey and United States Burean of Reclamation, 197. Scale, 1:15,840. Contour interval, 10 feet. Topography to 80 feet. Published map scale, 1:42,240. Published in report on Pit Rirer Basin by United States Bureau of Reclamation and State of California, 1915.

Round Valley dam site. Scale, $1: 6,000$.

(b) Squaw Creek from mouth to sec. 29 , T. 35 N., R. 2 W., 10 miles (11BF). Shown on 1933-34 surrey of Sacramento River and tributaries. 
(b) McCloud River from mouth to sec. 21, T. 36 N., R. 3 W., about 20 miles (11BF). Shown on 1933-34 survey of Sacramento River and tributaries.

(a) Backbone Creek from mouth to sec. 8, T. 34 N., R. 5 W., 7 miles (11BG). Shown on 1933-34 survey of Sacramento River and tributaries.

(a) Clear Creek from month to French Gulch, 32 miles (11BH). Shown on three sheets (two plan, one profile) 1934-36 survey of Sacramento River and tributaries.

Whiskeytown dam site, at mile 18.5 in sec. 27 , T. 32 N., R. 6 W. Scale, $1: 4,800$. Contour interval, 10 feet on land, 1 foot on water. Topography to 260 feet.

(a) Deer Creek from point 8.3 miles from mouth upstream to sec. 26 , T. 28 N., R. 5 E., 46 miles (11BN). Plan and profile, 1931-32. Scale, 1:31,680. Contour interval, 20 feet. Topography detailed. Published in three sheets (two plan, one showing dam site, and one profile).

Deer Creek Meadows dam site, in sec. 29, T. 28 N., R. 5 E. (11BN). Scale, 1:4,800. Contour interval, 10 feet. Topography to 200 feet.

(b) North Fork Deer Creek from mouth to source, including topography along possible line of diversion of Mill Creek to Deer Creek, 9 miles (11BN). Plan and profile, 1931-32. Scale, 1:31,680. Contour interval, 20 feet. Very little topography except at upper end and near mouth. Shown on two sheets (one plan, one profile), 1931 survey of Deer Creek.

(a) Feather River (11C).

(b) Middle Fork Feather River from mouth in sec. 25, T. 20 N., R. 4 E., to Nelson Point, 56 miles (11CE). Plan and profile, 1912. Scale, 1:31,680. Contour interval, 100 feet on land, 5 feet on water. Topography to $100-400$ feet. Published in four sheets in report by State Water Commission of California, 1912.

(b) Yuba River from sec. 23 , T. 16 N., R. 6 E., to sec. 12, T. 17 N., R. 7 E., about 15 miles (11CJ, 11CK), showing Upper Narrows reservoir site. Plan, 1934-35. Scale, $1: 12,000$. Contour interval, 20 feet on land, 5 feet on water. Topography detailed. Published in three sheets (one showing Upper Narrows dam site). 1937.

(b) Yuba River from dam of California Debris Commission to Smartville Narrows, 4 miles (11CJ). Plan, 1905. Scale, 1: 6,000. Contour interval, 2 feet, Topography detailed. Surveyed in connection with study of transportation of debris by running water. Two sheets. Not published.

Upper Narrows dam site in sec. 14, T. 16 N., R. 6 E. Scale, 1:2,400. Contour interval, 10 feet. Topography to 600 feet.

(b) Yuba River from confluence of North Fork and Middle Fork to point 1.5 miles downstream (11CG), and tributaries. Plan and profile by United States Geological Survey in cooperation with Corps of Engineers, United States Army, 1926, and 1931-36. Scale, 1:31,680. Contour interval, 20 feet on land, 5 and 20 feet on water. Topography detailed. Complete survey includes 46 miles on North Fork, 53 miles on Middle Fork, 65 miles on South Fork, and parts of minor tributaries. Published in 12 sheets ( 8 plan, 1 showing short section above, 6 showing dam sites, and 4 profile), 1940.

(c) North Fork Yuba River from junction with Middle Fork to Ladies Canyon sec. 27, T. 20 N., R. 11 E., 46 miles (11CG), and dam sites. Dam-site contour interval, 10 feet. Shown on three sheets, 1934-36 survey of Yuba River and tributaries.

Shady Flat dam site at mile 42.2, in sec. 31 , T. 20 N., R. 11 E. Scale, 1:2,400. Topography to 300 feet.

Goodyears Bar dam site, at mile 33.3. in sec. 6, T. 19 N., R. 10 E. Scale 1: 4,800. Topography to 300 feet. 
Indian Valley dam site at mile 25.0, in sec. 18, 'T. 19 N., R. 9 E. Scale, $1: 4,800$. Topography to 250 feet.

(c) Middle Fork Yuba River from junction with North Fork Yuba River to sec. 3, T. 18 N., R. 13 E., 53 miles $(11 \mathrm{CH})$, and dam sites. Shown on two sheets, 1934-36 survey of Yuba River and tributaries.

Freemans Crossing dam site at mile 3.4 in sec. 32, T. 18 N., R. 8 E.

Scale, 1:1,200. Contour interval, 5 feet. Topography to 240 feet.

English Meadows dam site at mile 51.7 in sec. 32, T. 19 N., R. 13 E.

Scale, $1: 4,800$. Contour interval, 10 feet. Topography to 130 feet.

Jackson Meadows dam site at mile 47.8 in sec. 18, T. 19 N., R. 13 E.

Scale, 1:2,400. Contour interval, 5 feet. Topography to 150 feet.

Emory Flat dam site, at mile 6.6 in sec. 26 , T. 18 N., R. 8 E. Scale,

1:2,400. Contour interval, 10 feet. Topography to 260 feet.

(c) South Fork Yuba River from mile 5 in sec. 36, T. 17 N., R. 7 E., to Soda Springs, at mile 65 (11CK), with tributaries and dam sites. Shown on 3 sheets, $1934-36$ survey of Yuba River and tributaries.

Upper Norton dam site, at mile 22.4 in sec. 13 , T. 17 N., R. 9 E. Scale

1: 1,200. Contour interval, 10 feet. Topography to 160 feet.

Governor Stephens dam site, at mile 32.5 in sec. 7, T. 17 N., R. 11 E.

Scale, $1: 4,800$. Contour interval, 10 feet. Topography to 350 feet.

Washington dam site, at mile 28.1 in sec. 10, T. 17 N., R. 10 E. Scale,

1: 4,800. Contour interval, 10 feet. Topography to 400 feet.

Jones Bar dam site, at mile 6.4 in sec. 31, T. 17 N., R. 8 E. Scale,

1:2,400. Contour interval, 5 feet. Topography to 330 feet.

(d) Canyon Creek from junction with South Fork Yuba River to French Lake, 19 miles (11CK). Shown on two sheets, 1934-36 survey of Yuba River and tributaries.

Deadhorse Flat dam site, at mile 5.6. Scale, $1: 4,800$. Contour interval, 10 feet. Topography to 300 feet.

(d) Fordyce Creek from junction with South Fork Yuba River to mile 6 (11CK) Shown on one sheet, 1934-36 survey of Yuba River and tributaries.

(d) Poorman Creek from junction with South Fork Yuba River to mile 3 (11CK). Shown on one sheet, 1934-36 survey of Yuba River and tributaries.

(c) Deer Creek from junction with Yuba River to sec. 17, T. 16 N., R. 8 E., 12 miles (11CJ). Shown on one sheet, 1934-36 survey of Yuba River and tributaries.

Anthony House dam site in sec. 20, T. 16 N., R. 7 E. Scale, 1:2,400.

Contour interval, 5 feet on land, 1 foot on water. Topography to 260 feet.

(a) Cache Creek from point 3 miles above Esparto to Bear Creek, sec. 32, T. 13 N., R. 4 W., 29 miles (11DB). Plan and profile, 1934-36. Scale, 1:31,680. Contour interval, 10 and 20 feet on land, 5 feet on water. Published in three sheets (one plan, one profile, and one dam site), 1939.

Dam site, at mile 4.0 in sec. 5 , T. 10 N., R. 2 W. Scale, $1: 2,400$. Contour interval, 10 feet. Topography to 200 feet.

Two auxiliary dam sites, scale, $1: 4,800$.

(a) American River from Folsom to confluence of North and South Forks, 3 miles (11DH). Plan and profile, 1912. Scale, 1:31,680. Contour interval, 25 feet on land, 5 feet on water. Topography to 100 feet. Published in 1 of 12 sheets showing North, Middle and South Forks by State Water Commissioner of California, 1912.

(a) American River from bridge at Folsom to confluence of North and South Forks, 3 miles (11DH). Plan and profile, 1935-36. Scale, 1:24,000. Contour interval, 20 feet with 10-foot contours added in places in dashed lines on land 
and 5 feet on water. Topography to 150 feet. Published in four plan sheets, one of which shows a dam site, two sheets showing dam sites, and two profile sheets, 1942.

Folsom dam site at mile 2.0 in sec. 24 , T. 10 N., R. 7 E. Scale, $1: 4,800$. Contour interval, 10 feet. Topography to 180 feet. Published with 1935-36 survey.

(b) North Fork American River from junction with South Fork to junction with Middle Fork, 20 miles and an additional 64 miles beyond the junction of North and Middle Forks, making a total of 84 miles (11DF, 11DD) and dam sites. Published in six sheets with the 1912 survey of American River described above.

(b) North Fork American River from junction with South Fork to junction with Middle Fork, 20 miles and an additional 17 miles beyond the junction of North and Middle Forks, making a total of 37 miles (11DD, 11DF) and dam sites. Dam-site scale, $1: 2,400$; contour interval, 10 feet. Published with the 1935-36 survey of the American River described above.

Pilot Creek dam site, at mile 16.6 in sec. 34,35 , T. 12 N., R. 8 E. Topography to 160 feet.

Lower Auburn dam site, at mile 22.2 in sec. 11, T. 12 N., R. 8 E. Topography to 500 feet.

(b) Middle Fork American River from confluence with North Fork to mile 20 (11DE). Shown on 1935-36 survey of American River.

(b) Middle Fork American River from mouth in sec. 1, T. 12 N., R. 8 E., to sec. 28, T. 15 N., R. 14 E., 50 miles (11DE). Plan and profile by United States Geological Survey, 1912. Scale, 1:31,680. Contour interval, 25 feet on land, 5 feet on water. Topography to 100 feet. Published in three sheets in report by State Water Commission of California, 1912.

(c) Rubicon River from mouth to elevation 6,605 feet, 49 miles (11DE). Profile by California Power Board, 1922. Scale, 1 inch $=8 \frac{1}{2}$ miles. Unpublished map in files of Federal Power Commission.

(d) Little South Fork of Rubicon River from mouth to point 5 miles above Gerla Creek, 15 miles (11DE). Profile compiled by California Power Board 1922. Scale, 1 inch $=81 / 2$ miles. Unpublished map in files of Federal Power Commission.

(e) Gerla Creek from mouth 7 miles upstream (11DE). Profile compiled by California Power Board, 1922. Scale, 1 inch $=81 / 2$ miles. Unpublished map in files of Federal Power Commission.

(d) Pilot Creek from mouth upstream 16 miles (11DE). Profile compiled by California Power Board, 1922. Scale, 1 inch $=81 / 2$ miles. Unpublished map in files of Federal Power Commission.

(b) South Fork American River from point 5 miles below Coloma power house, upstream 43 miles (11DG). Profile compiled by California Power Board, 1922. Scale, 1 inch $=81 / 2$ miles. Unpublished map in files of Federal Power Commission.

(b) South Fork American River from mouth in sec. 19, T. 10 N., R. 8 E., to sec: 24, T. 11 N., R. 12 E., 49 miles (11DG). Plan and profile by United States Geological Survey, 1912. Scale, $1: 31,680$. Contour interval, 25 feet on land, 5 feet on water. Topography to 100 feet. Published in three sheets in report by State Water Commission of California, 1912.

(b) South Fork American River from mouth to mile 31 (11DG), and dam sites. Dam-site scale, 1:4,800; contour interval, 10 feet. Shown on 1935-36 survey of American River.

Coloma dam site, at mile 13.7. in sec. 28,29 , T. 11 N., R. 9 E. Topography to 450 feet. 
Webber Creek dam site, at mile 11.3 in sec. 30 , T. 11 N., R. 9 E. Topography to 200 feet.

(c) Echo Lake reservoir site in sec. 35, 36, 'న. 12 N., R. 17 E., and sec. 1, 2, T. 11 N., R. 17 E. (11DG). Plan by engineers of city of Sacramento. Scale, 1: 11,800. Contour interval, 10 feet. Dam site scale, 1:2,180; contour interval, 10 feet. Published in report on possible sources of water supply for the city, by city commission of Sacramento, 1916.

(c) Silver Fork. (11 DG).

(d) Twin Lakes reservoir site in sec. 13, 24, T. 10 N., R. 17 E., and sec. 17, 18, 19, 20, 30, T. 10 N., R. 18 E. (11DG). Plan by engineers of city of Sacramento. Scale, $1: 14,300$. Contour interval, 5 feet. Dam site scale, $1: 2,500$ and $1: 1,285$; contour interval, 2 feet. Published in report on possible sources of water supply for the city, by city commission of Sacramento, 1916.

(d) Silver Lake reservoir site in sec. 5, T. 9 N., R. 17 E., and sec. 32, T. 10 N., R. 17 E. (11DG) ). Plan by engineers of city of Sacramento. Scale, 1: 12,600. Contour interval, 10 feet. Dam site scale, 1:2,500; contour interval, 2 feet. Published in report on possible sources of water supply for the city, by city commission of Sacramento, 1916.

(c) Alder Creek reservoir site from dam site in sec. 8, T. 10 N., R. 15 E., upstream about 2 miles (11DG). Plan by engineers of city of Sacramento. Scale, 1: 10,200. Contour interval, 10 feet. Topography to 150 feet at dam site. Published in report on possible sources of water supply for the city, by city commission of Sacramento, 1916.

(c) Silver Creek from mouth to Tells Creek, 11 miles (11DG). Profile compiled by California Power Board, 1922. Scale, 1 inch $=81 / 2$ miles. Unpublished map in files of Federal Power Commission.

(a) Putah Creek from point 2 miles above Winters, T. 8 N., R. 1 W., to Middletown, mile 59 (11DC). Plan and profile, 1933-35. Scale, 1:31,680. Contour interval, 20 feet on land, 5 feet on water. Topography detailed. Dam-site scale, 1:4,800; contour interval, 10 feet, except as noted. Published in six sheets (three plan, one profile, two showing dam sites), 1938.

Monticello dam site, at mile 7.2 in sec. 29 , T. 8 N., R. 2 W. Scale, 1:2,400. Topography to 200 feet.

Upper Monticello dam site, at mile 24.9, T. 9 N., R. 4 W. Scale, 1:2,400. Topography to 170 feet.

Devils Head dam site, at mile 36.7 in sec. 3, T. 10 N., R. 5 W. Topography to 180 feet.

. Coyote Valley dam site, at mile 48.0, T. 11 N., R. 6 W. Also Coyote Valley Auxiliary A and Coyote Valley Auxiliary B. Topography to 180 feet at main dam site.

(b) Butte Creek from mouth to mile 4 in sec. 20, T. 10 N., R. 5 W. (11DC). Shown on two sheets (one plan, one profile), 1933-35 survey of Putah Creek.

(b) Jerusalem Creek from mouth to mile 5, sec. 27, T. 12 N., R. 6 W. (11DC). Shown on two sheets (one plan, one profile), 1983-35 survey of Putah Creek.

Jerusalem Creek dam site, at mile 0.5 in sec. 14, T. 11 N., R. 6 W. Scale, 1: 4,800. Contour interval, 10 feet. Topography to 120 feet.

EeL River. (11 ED).

(a) Middle Fork Eel River from mouth to sec. 11, T. 23 N., R. 11 W., 34 miles (11ED), and tributaries. Plan and profile, 1924-25. Scale, 1:31,680. Contour interval, 25 feet on land, 5 feet on water. Topography detailed. Published in three sheets (two plan, one profile), 1926.

(b) Black Butte River from mouth to sec. 1, T. 22 N., R. 11 W., 4 miles (11ED). Shown on two sheets (one plan, one profile) in set of three, 1924-25 survey of Middle Fork Eel River and tributaries. 
(b) Williams Creek from mouth upstream to sec. 7, T. 23 N., R. 11 W., 4 miles (11ED). Shown on two sheets (one plan, one partial profile) in set of three, 1924-25 survey of Middle Fork Eel River and tributaries.

(b) Mill Creek from mouth to sec. 15, T. 23 N., R. 13 W., 12 miles (11ED), including all of Round Valley to elevation 1,550 feet. Shown on three sheets (two plan, one partial profile), 192t-25 survey of Middle Fork Eel River and tributaries.

(b) Elk Creek from mouth upstream to sec. 25, T. 20 N., R. 11 W., 10 miles (11ED). Shown on two sheets (one plan, one profile) in set of three, 1921-25 survey of Middle Fork Eel River and tributaries.

Klamath River from sec. 13, T. 13 N., R. 1 E., to sec. 28, T. 13 N., R. 2 E, 5 miles (11AL) and from sec. 12, T. 10 N., R. 3 E., to Oregon-California State line, 177 miles $(11 \mathrm{AL}, 11 \mathrm{AJ}, 11 \mathrm{AG}, 11 \mathrm{AE})$, and tributaries. Plan and profile, 1913-23. Scale, $1: 48,000$. Contour interval, 25 feet on land ; 5 feet on water. Topography 150-400 feet. Published in 14 sheets (eight plan, six profile), 1925. Complete surrey includes also 25 miles in Oregon, published in $\mathbf{1 6}$ sheets (nine plan, seven profile) ; and dam sites on Klamath River (nine in California, three in Oregon), surveyed 1915, 1921, and 1923, scale 1:2,400, contour interval 10 feet, comprising 3 sheets in set of 4 showing miscellaneous dam sites on Klamath River in California and Oregon.

Tully Rapids dam site, at mile 08 . Topography to 170 feet.

Weitchpec dam site, at mile 9.0. Topography to 120 feet.

Slate Creek dam site, at mile 15.7. Topography to 245 feet.

$\mathbf{R}$ d Cap dam site, at mile 19.3. Topography to 260 feet.

Sugarloaf dam site, at mile 32.0. Topography to 340 feet.

Shasta dam site, at mile 143.2. Topography to 190 feet.

Brush Creek dam site, at mile 156.8. Topography to 190 feet.

Jenny Creek dam site, at mile 162.1. Topography to 120 feet.

Fall Creek dam site, at mile 164.5. Topography to 90 feet.

Jackman dam site, in sec. 12 or 13, T. 10 N., R. 3 E., Humboldt meridian.

(11AL). Plan by California Power Board, 1922. Scale, 1: 1,800. Contour interval, 10 feet. Topography to 180 feet. Unpublished map in files of Federal Power Commission.

(a) Scott River from mouth to sec. 28 , T. 44 N., R. 10 W., 22 miles (11AH). Plan and profile, 1914. Shown on two sheets (one plan, one profile), 1913-23 survey o1: Klamath River and tributaries.

(a) Salmon River from mouth to forks in sẹc. 13, T. 10 N., R. 7 E., 19 miles (1.1AK). Plan and profile, 1914-15. Topography to 125-400 feet. Shown on two sheets (one plan, one profile), 1913-23 survey of Klamath River and tributaries.

(b) North Fork Salmon River from mouth to sec. 19, T. 40 N., R. 10 W., 21 miles (11AK). Plan and profile, 1914-15. Shown on two sheets (one plan, one profile), 1913-23 survey of Klamath River and tributaries.

(b) South Fork Salmon River from mouth in sec. 13, T. 10 N., R. 7 E., Humboldt meridian, to Little Grizzly Creek in sec. 18, T. 37 N., R. 10 W., Mount Diablo meridian, 30 miles (11AK). Plan and profile, 1914-15. Topography to 100-400 feet. Shown on three sheets (one plan, two profile), 1913-23 survey of Klamath River and tributaries.

(a) Trinity River and tributaries from Douglas City to Carrville, 53 miles on main stream (11AM), and dam sites. Plan and profile, 1934-36. Scale, 1: 31,680. Contour interval, 10 and 20 feet on land, 5 feet on water. Dam-site scale, $1: 4,800$; contour interval, 10 feet. Topography detailed. Published in four sheets (three plan, showing also dam sites, and one profile), 1939. 
Lowden dam site, at mile 8.4 in sec. 28 , T. 33 N., R. 9 W. Topography to 310 feet.

Deadwood dam site, at mile 18.6 in sec. 17, T. 33 N., R. 8 W. Topography to 500 feet.

Lewiston dam site, at mile 20.3 in sec. 8 , T. 33 N., R. 8 W. Topography to 200 feet.

Fairview dam site, at mile 29.0 in sec. 10 , T. 34 N., R. 8 W. Topography to 480 feet.

Trinity Center dam site, at mile 36.0 in sec. 24 , T. 35 N., R. 8 W. Topography to 480 feet.

(a) Trinity River and tributaries from Douglas City downstream 18 miles tying in at Douglas City with the plan and profile map described above (11AM). Plan and profile, 1945. Scale, $1: 31,680$. Contour interval, 20 feet on land and 5 feet on water. Topography $\mathbf{3 0 0}-\mathbf{4 0 0}$ feet. In preparation.

The following tributaries of Triinty River are included on the same map.

(b) Dutton Creek from mouth upstream 1 mile.

(b) Browns Creek from mouth upstream 7.5 miles.

(c) Little Browns Creek from mouth upstream 1 mile.

(b) Unnamed Creek from mouth upstream 1.5 miles.

(b) Dutch Creek from mouth upstream 2 miles.

(b) Soldier Creek from mouth upstream 1 mile.

(b) Oregon Gulch from mouth upstream 2 miles.

(b) Canyon Creek from mouth upstream 1 mile.

(a) Trinity River from mouth to sec. 29, T. 6 N., R. 6 E., 39 miles (11AN), and dam site. Plan and profile, 1921. Scale, 1:48,000. Contour interval 25 feet on land, 5 feet on water. Topography to 200-300 feet. Shown on three sheets (one plan, two profile), 1913-23 survey of Klamath River and tributaries; dam site shown on one sheet miscellaneous dam sites, same survey.

Horse Linto Creek dam site, at mile 20. Scale, 1:2,400. Contour interval, 10 feet. Topography to 240 feet.

(a) Trinity River from mouth to point about 20 miles above Lewiston, 110 miles (11AM, 11AN), and dam sites. Profile by California Power Board, 1922. Scale, 1 inch =15 miles. Unpublished map in files of Federal Power Commission.

Unpublished maps of the following dam sites on Trinity River were prepared by the California Power Board, 1922, and are in the files of the Federal Power Commission.

Fairview dam site, 6 miles above Lewiston, in sec. 10, T. 34 N., R. 8 W. Scale, $1: 2,740$. Contour interval, 50 feet. Topography to 350 feet.

Lewiston dam site, in sec. 8 , T. 33 N., R. 8 W. Scale, 1:2,800. Contour interval, 25 feet. Topography to $\mathbf{1 7 5}$ feet.

Steiners Flat dam site, in sec. 34, T. 33 N., R. $10 \mathrm{~W}$. Scale, 1:2,400. Contour interval, 10 and 100 feet. Topography to 1,500 feet.

Helena dam site, in sec. 32 , T. 34 N., R. 11 W. Scale, 1:3,600. Contour interval, 10 feet. Topography to 370 feet.

Swede dam site, in sec. 23 , T. 5 N., R. 7 E. Scale, 1:2,400. Contour interval, 100 feet. Topography to 2,000 feet.

Ironside Mountain dam site, in sec. 35, T. 6 N., R. 6 E. Scale 1: 1,800 Contour interval, 10 feet. Topography to 270 feet.

Salyer dam site, in sec. 19, T. 6 N., R. 6 E. Scale, 1:1,800. Contour interval, 10 feet. Topography to 180 feet.

Beaver dam site, 5 miles above mouth of Trinity River, in sec. 35, $\mathbf{T}$. 9 N., R. 4 E. Scale, 1:1,800. Contour interval, 10 feet. Topography to 180 feet. 
(b) East Fork Trinity River from mouth to mile 4 (11AM). Shown on one sheet, 1934-36 survey of Trinity River and tributaries.

(b) Stuart Fork Trinity River from mouth to mile 7 (11AM). Shown on one sheet, 193t-36 survey of Trinity River and tributaries.

(c) East Fork Stuart Fork from mouth to mile 6 (11AM). Shown on one sheet, 1934-36 survey of Trinity River and tributaries.

(b) Rush Creek from mouth to mile 4 (11AM). Shown on one sheet, 1934-36 survey of Trinity River and tributaries.

(b) Weaver Creek from mouth to mile 4 (11AM). Shown on one sheet, 193436 survey of Trinity River and tributaries.

(b) South Fork Trinity River from mouth to sec. 26, T. 6 N., R. 5 E., 5 miles (11AO). Plan and profile, 1921. Scale, 1:48,000. Contour interval, 25 feet on land, 5 feet on water. Topography to $75-200$ feet. Shown on parts of two sheets (one plan, one profile), 1913-23 survey of Klamath River and tributaries.

(b) South Fork Trinity River. Dam site plan by California Power Board, 1922. Unpublished map in files of Federal Power Commission.

Hyampom dam site, at mile 18, T. 3 N., R. 6 E. Scale, 1:3,600. Contour interval, 10 feet. Topography to 350 feet.

SMITH RIVER (12RE).

(a) South Fork Smith River from sec. 30 , T. 16 N., R. 2 E., to sec. 33, T. 15 N., R. 3 E., 16 miles (12RE). Plan and profile, 1914-15. Scale, 1:48,000. Contour interval, 25 feet on land, 5 feet on water. Topography to 250 feet. Shown on two sheets (one plan, one profile), 1913-23 survey of Klamath River and tributaries.

Small-scale maps of river basins in California and diagrams showing plans of power development are published in report entitled Hydroelectric power systems of California and their extensions into Oregon and Nevada, Water-Supply Paper 493.

For areas in California covered by United States Geological Survey standard topographic maps see plate 1 .

\section{COLORADO}

Mississippi River Basin $(6,7)$.

(a) Missouri River (6).

(b) Platte River (6M).

(c) South Platte River from Eagle Rock in sec. 6, T. 8 S., R. 69W., to sec. 21, T. 12 S., R. 76 W., 97 miles (6OA, 6OC), including South Fork. Plan and profile, 1922. Scale, $1: 31,680$. Contour interval, 50 feet. Topography to $300-500$ feet. Three sheets. Not published.

(c) South Platte River from line between T. 6 and 7 S., R. 69 W., to North Fork, 7 miles (6OE). Plan and profile, 1923. Scale, 1:31,680. Contour interval, 50 feet. Topography to 300 feet. Plan shown on one sheet. Not published.

(d) North Fork South Platte River from mouth to Kanosha Creek, 43 miles (6OD). Plan and profile, 1922. Scale, 1:31,680. Contour interval, 50 feet. Topography to 300 feet. Plan shown on one sheet. Not published.

(e) Geneva Creek from mouth to sec. 13, T. 6 S., R. 75 W., 7 miles (6OD). Plan and profile, 1922. Scale, 1:31,680. Contour interval, 50 feet. Topography to 150-250 feet. Plan shown on one sheet with part of North Fork South Platte River. Not published.

(d) Clear Creek in sec. 33, T. 3 S., R. 74 W., 1 mile (6OF). Plan and profile, 1923. Scale, 1:6,000. Contour interval, 20 and 100 feet. Topography detailed. Not published. 
(d) Clear Creek from sec. 36 , T. 3 S., R. 71 W., to sec. 17, T. 4 S., R. 75 W., 37 miles (6OF), including Middle Fork. Plan and profile, 1923. Scale, 1:63,360. Contour interval, 50 feet. Topography to 300 feet. Plan shown on one sheet. Not published.

(e) South Fork Clear Creek from mouth to sec. 29, T. 4 S., R. 74 W., 2 miles (6OF). Plan and profile, 1923. Scale, 1:63,360. Contour interval, 50 feet. Topography to 200-300 feet. Plan shown on part of one sheet. Not published.

(e) Chicago Creek from mouth to sec. 24, T. 4 S., R. 74 W., 7 miles (6OF). Plan and profile, 1923. Scale, 1:63,360. Contour interval, 50 feet. Topography to 300 feet. Plan shown on part of one sheet. Not published.

(e) North Fork Clear Creek from mo'th to sec. 34, T. 2 S., R. 73 W., 8 miles (6OF). Plan and profile, 1923. Scale, 1:63,360. Contour interval, 50 feet. Topography to 300 feet. Plan shown on part of one sheet. Not published.

(d) St. Vrain Creek (6OJ).

(e) North St. Vrain Creek from sec. 17 , T. 3 N., R. 70 W., to sec. 19, T. 3 N., R. 72 W., 20 miles (60J). Plan and profile, 1923, Scale, 1:63,360. Contour interval, 50 feet. Topography to 300 feet. Plan shown on part of one sheet. Not published.

(e) South St. Vrain Creek from sec. 17, T. 3 N., R. 70 W., to section 30, T. 2 N., R. 72 W., 19 miles (6OJ). Plan and profile, 1923. Scale, 1:63,360. Contour interval, 50 feet. Topography to 300 feet. Plan shown on part of one-sheet. Not published.

(f) Middle St. Vrain Creek from mouth to sec. 18, T. 2 N., R. 72 W., 8 miles (60J). Plan and profile, 1923. Scale, 1:63,360. Contour interval, 50 feet. Topography to 300 feet. Plan shown on part of one sheet. Not published.

(e) Lefthand Creek from sec. 23 , T. 2 N., R. 71 W., to sec. 10, T. 1 N., R. 72 W., 12 miles (6OJ). Plan and profile, 1923. Scale, 1:63,360. Contour interval, 50 feet. Topography to 300 feet. Plan shown on part of one sheet. Not published.

(f) James Creek from mouth to sec. 31, T. 2 N., R. 72 W., 11 miles (60J). Plan and profile, 1923. Scale, $1: 63,360$. Contour interval, 50 feet. Topography to 300 feet. Plan shown on part of one sheet. Not published.

(e) Boulder Creek $(6 \mathrm{OH})$.

( $f$ ) Middle Boulder Creek from Boulder in T. 1 N., R. 71 W., to sec. 18, T. 1 S., R. 73 W., 23 miles $(60 H)$. Plan and profile, 1923. Scale, 1:63,360. Contour interval, 50 feet. Topography to 300 feet. Plan shown on one sheet with South Fork Boulder Creek. Not published.

(f) South Bonlder Creek from sec. 26, T. 1 S., R. 71 W., to sec. 6, T. 2 S., R. 73 W., 26 miles $(6 \mathrm{OH})$. Plan and profile, 1923. Scale, 1:63,360. Counter interval, 50 feet. Topography to 300 feet. Plan shown on one sheet with Middle Boulder Creek. Not published.

(d) Thompson River from sec. 12 , T. 5 N., R. 70 W., to sec. 26 , T. 5 N., R. 73 W., 30 miles $(60 J)$. Plan and profile, 1923. Scale, 1:63,360. Contour interval, 50 feet. Topography to 300 feet. Plan shown on one sheet. Not published.

(d) Cache La Poudre River from sec. 4, T. 8 N., R. 70 W., to sec. 34, T. 8 N., R. 75 W., 50 miles (6OK). Plan and profile, 1923. Scale, 1:63,360. Contour interval, 50 feet. Topography to 300 feet. Plan shown on one sheet. Not published.

(a) Arkansas River from sec. 15, T. 8 S., R. 79 W., to sec. 4, T. 49 N., R. 9 E., 77 miles (7AA, 7AB). Plan and profile, 1921. Scale, $1: 63,360$. Contour interval, 50 feet. Topogranky to 250-400 feet. Plan shown on two sheets. Not published.

(a) Arkansas River from sec. 4, T. 49 N., R. 9 E., to sec. 32, T. 18 S., R. 70 W., 55 miles $(7 \mathrm{AB}, 7 \mathrm{AC})$. Plan and profile, 1921. Scale, 1:31,680. Contour interval, 50 feet. Topogranhy to $250-500$ feet. Plan shown on one sheet. Not published. 
(b) Tennessee Fork from mouth to sec. 22, T. 8 S., R. 20 W., 6 miles (7AA). Plan and profile, 1921. Scale, 1:63,360. Contour interval, 50 feet. Topography to 300 feet. Plan shown on part of one sheet. Not published.

(b) Halfmoon Creek from mouth to sec. 19, T. 10 S., R. 81 W., 10 miles (7AA). Plan and profile, 1922. Seale, $1: 31,680$. Contour interval, 50 feet. Topography to $200-2,000$ feet. Shown on one sheet. Not published.

(b) Lake Creek from sec. 24 , T. 11 S., R. 81 W., to sec. 3, T. 11 S., R. 82 W., 20 miles (7AA). Plan and profile, 1922. Scale, 1:31,680. Contour interval, 50 feet. Topography to 500-800 feet. Shown on two sheets. Not published.

(b) Cottonweed Creek from mouth to sec. 8 , T. 15 S., R. 80 W., 17 miles (7AA). Plan and profile, 1922. Scale, 1:31,680. Contour interval, 50 feet. Topography to 50-500 feet. Plan and profile on one sheet. Not published.

(b) Chalk Creek from mouth to sec. 36, T. 51 N., R. 6 E., 24 miles (7AB). Plan and profile, 1922. Scale, 1:31,680. Contour interval, 50 feet. Topography to 50-500 feet. Plan and profile on one sheet. Not published.

(b) South Fork Arkansas River from mouth to sec. 5, T. 49 N., R. 6 E., 21 miles (7AR). Plan and profile. 1922. Scale, 1:31,680. Contour interval. 50 feet. Tonography to 200-600 feet. Plan and profile on one sheet. Not published.

(h) Grape Creek from sec. 36, T. 21 S., R. 73 W., to sec. 6, T. 19 S., R. 70 W., $\therefore 9$ miles (7AD). Plan and profile. 1921. Scale. 1:31,680. Contour interval, 50 feet. Topography to $150-400$ feet. Plan on one sheet. Not published.

(b) Reaver Creek from sec. 16, T. 17 S., R. 68 W., to forks in sec. 5 , T. $17 \mathrm{~S}$., R. 68 W., 2 miles (7AD). Plan and profile, 1921. Scale, 1:31,680. Contour interval, 50 feet. Topography to $\mathbf{1 . 0 0 0}$ feet. Not published.

(c) East Fork Beaver Creek from mouth to sec. 15, T. 16 S., R. 68 W., 4 miles (7AD). Plan and profile, 1921. Scale. $1: 31,680$. Contour interval, 50 feet. Topography to 200-1,000 feet. Not published.

(c) West Fork Beaver Creek from mouth to sec. 36, T. 15 S., R. 69 W., 9 miles (7AD). Plan and profile, 1921. Scale, 1:31,680. Contour interval, 50 feet. Topography tn $50-800$ feet. Not published.

Colorado RIver from Kremmling in sec. 18, T. 1 N.. R. 80 W., to Glenwood Springs, 90 miles (9DC, 9DE). Plan and profile, 1911. Scale, 1:31,680. Contour interval. 25 feet on land, 5 feet on water. Topography to 200-400 feet. Published in Water-Supply Paper 396.

Colorado RIver (9DA), Kremmling reservoir site. Plan by United States Burean of Reclamation, 1905. Scale, 1:48,000. Contour interval, 20 feet. Topography to 200 feet at dam site.

Jam sites in Gore Canyon immediately below reservoir. Scale, $1: 2,400$

Contour interval, 10 feet. Topography to 200 feet.

Colorado River from Grand Junction to Colorado-Utah State line, 40 miles (9DM). Plan and profile, 1911. Scale, 1:31,680. Contour interval, 25 feet on land, 5 feet on water. Topograp'y to 25-600 feet. Part of map of Colorado River from Grand Junction, Colo., to mouth of Green River, Utah. Published in WaterSupply Paper 396.

Cororado River from canyon below Moab, Utah, to Mack, Colo., 69 miles in Utah and 16 in Colorado (9DM). This includes the Dewey reservoir site. Plan and profile by United States Geological Survey and Burean of Reclamation, 1941 and 1943-45. Scale, 1: 24,000 . Contour interval, 20 feet on land and 5 feet on water. Topography to 300 feet. Published in 14 sheets (11 plan, 3 profi!e), 1948.

(a) Troubiesome (reek from sec. 11, T. 3 N., R. 80 W., upstream 3 miles (9DA), Rabbit Ear reservoir sitn, including East Fork Troublesome Freek. Surveyed by United States Geological Survey in cooperation with United States Bureau of Reclamation, 1937. Scale, 1: 12,000. Contour interval. 10 feet on land, 5 feet on 
water. Topography detailed. Published in two sheets (one plan, one profile), 1940.

(b) East Fork Troublesome Creek from sec. 32. T. 3 N., R. 79 W., upstream 6 miles (9DA), showing East Fork reservoir site. Shown on one sheet, 1937 survey of Troublesome Creek.

(a) Blue River from mouth to Breckenridge, 58 miles (9DB). Plan and profile, 1924. Scale, 1:63,360. Contour interval, 50 feet. Topography to 300 feet. Plan shown on one sheet. Not published.

(a) Blue River from sec. 10, T. 1 S., R. 80 W., to sec. 2, T. 2 S., R. 79 W., 10 miles (9DB), including Green Mountain reservoir site. Plan, 1924. Scale, 1:31,680. Contour interval, 50 feet. Topography detailed. One sheet. Not published.

(a) Eagle River from mouth to sec. 30, T. 6 S., R. 80 W., 52 miles (9DD). Plan and profile, 1924. Scale, 1:31;680. Contour interval, 50 feet. Topography to 200-600 feet. Plan shown on one sheet. Not published.

(a) Roaring Fork from mouth to Snowmass, sec. 27, T. 8 S., R. 86 W., 29 miles (9DF). Plan and profile, 1924. Scale, 1:31,680. Contour interval, 50 feet. Topography to 200-300 feet. Plan on one sheet. Not published.

(a) Roaring Fork from mouth to point 10 miles above Aspen, Colo., 55 miles (9DF). Plan and profile, 1934-38. Scale, 1:31,680. Contour interval, 20 feet on land, 5 feet on water. Topography detailed. Published in five sheets (three plan, two profile), 1941.

(b) Frying Pan Creek from mouth upstream 2 miles (9DF). Shown on one sheet, 1934-38 survey of Roaring Fork.

(b) Frying Pan Creek from point 2 miles above mouth to Chapman Gulch in sec. 34, T. 8 S., R. 83 W., 24 miles (9DF). Plan and profile, 1934 . Scale 1: 31,680. Contour interval, 20 feet on land, 5 feet on water. Topography detailed. Published in two sheets (one plan, one profile), 1939.

Ruedi dam site, at mile 11.5 in sec. 18 , T. 8 S., R. 84 W. Scale, $1: 4,800$. Contour interval, 10 feet. Topography to 200 feet.

(b) Crystal River from Carbondale to Marble, 29 miles (9DF), and Crystå River dam site. Plan and profile, 1934. Scale, 1:31,680. Contour interval, 20 feet on land, 5 feet on water. Topography detailed. Published in two sheets (one plan, showing also Crystal River dam site, and one profile), 1939.

Crystal River dam site, at mile 12.5 in sec. 33 , T. 9 S., R. 88 W. Scale, 1: 4,800. Contour interval, 10 feet. Topography to 200 feet.

(b) Cattle Creek from point 1 mile above mouth to sec. 9, T. 7 S., R. 87 W., 10 miles (9DF). Plan and profile, 1934. Scale, 1:31,680. Contour interval, 20 feet. Topography to 100-200 feet. Published in one sheet, 1939.

Cattle Creek dam site, at mile 7.5 in sec. 8 , T. 7 S., R. 87 W. Scale, 1:4,800. Contour interval, 10 feet. Topography to 200 feet.

(c) Coulter Creek from mouth to mile 2 (9DF), showing small reservoir site. Shown on part of one sheet, 1934 survey of Cattle Creek.

Coulter Creek dam site in sec. 5, T. 7 S., R. 87 W. Scale, 1:4,800.

Contour interval, 10 feet. Topography to 60 feet.

(a) Plateau Creek.

(b) Buzzard Creek from sec. 28, T. 9 S., R. 92 W., to Crane Creek, about 4 miles (9DJ), showing Owens Creek reservoir site. Plan, 1936. Scale, 1:24,000. contour interval, 10 feet on land, 5 feet on water. Topography detailed. Published in one sheet, 1937.

(a) Gunnison River from Lake Fork to Junction of Taylor River and East River, 40 miles (9EC, 9EA), and dam sites. Plan and profile, 1934-36. Scale, 1:31,680. Contour interval, 20 feet on land, 5 feet on water. Shows wide area of adjacent topography. Dam site scale, 1:4,800; contour interval, 10 feet. 
Published in eight sheets (five plan, showing also dam sites, and three profile), 1938.

Lake Fork Junction dam site, at mile 0.5, approximately in sec. 4, T. 48 N., R. $4 \mathrm{~W}$. Topography to 220 feet.

No. 1-A dam site, at mile 19.5 in sec. 23,26, T. 49 N., R. 2 W. Topography to 350 feet.

No. 2-A dam site, at mile 20.0 in sec. 23,26, T. 49 N., R. 2 W. Topography to 250 feet.

No. 3-A dam site, at mile 20.7 in sec. 24 , T. 49 N., R. 2 W. Topography to 270 feet.

No. 3 dam site, at mile 39 in sec. 27 , T. 51 N., R. 1 E. Topography to 350 feet.

(a) Gunnison River from Cimarron Creek to Gunisson in sec. $2, T$. 49 N., $\mathbf{R}$. 1 W., 39 miles (9EC). Plan and profile, 1909. Scale, 1:31,680. No topography. Published in Water-Supply Paper 396.

(b) Taylor River to mile 4 (9EA). Shown on one sheet, 1934-36 survey of Gunnison River.

(b) East River to sec. 3, T. 13 S., R. 86 W., 30 miles (9EA). Shown on two sheets, 1934-36 survey of Gunnison River.

Dam site, at mile 41.1 in sec. 15 , T. 51 N., R. 1 E. Scale, 1:4,800. Contour interval, 10 feet. Topography to 200 feet.

(c) Slate River from junction with East River to sec. 20, T. 13 S., R. 86 W., 15 miles (9EA). Shown on one sheet, 1934-36 survey of Gunnison River.

(b) Sapinero Creek from mouth to mile 3 (9EC). Shown on one sheet, 1934-36 survey of Gunnison River.

(b) Lake Fork Gunnison River from mouth to Lake San Crystobal, 42 miles (9EC). Shown on two sheets, 1934-36 survey of Gunnison River.

The following dam sites on Lake Fork of Gunnison River are shown on the 1934-36 survey of Gunnison River. Scale, 1:4,800. Contour interval, 10 feet.

Independence Creek dam site, at mile 31.8 in sec. 2 , T. 44 N., R. 4 W. Topography to 160 feet.

Gates dam site at mile 19.4 in sec. 7, T. 46 N., R. 3 W. Topography to 460 feet.

Riverside School dam site, at mile 14.1 in sec. 21 , T. 47 N., R. 3 W. Topography to 180 feet.

Madera Siding dam site, at mile 12.4 in sec. 17, T. 47 N., R. 3 W. Topography to 230 feet.

(a) Dolores River from Mesa-Montrose county line in T. 49 N., R. 18 W., to point 3 miles above mouth of Disappointment Creek, 87 miles (9DK, 9DL). Plan and profile, 1915-16. Scale, $1: 48,000$. Contour interval, 100 feet on land, 5 feet on water. Shown on three sheets in set of five covering Dolores River and San Miguel River, Colo., within Paradox Valley quadrangle.

(a) Dolores River from Paradox Valley, sec. 31, T. 47 N., R. 18 W., to ColoradoUtah State line, 55 miles (9DL, 9DK). Plan and profile, 1924. Scale, 1:31,680. Contour interval, 50 feet. Topography to 200-800 feet. Plan of river from mouth in Utah to Paradox Valley in Colorado shown on one sheet. Not published.

(b) San Miguel River from mouth to point in sec. 15, T. 46 N., R. 15 W., 3 miles above Naturita Creek, 27 miles (9DK). Plan and profile, 1915-16. Scale, 1: 48,000. Contour interval, 100 feet on land, 5 feet on water. Detailed topography. Published on two sheets in set of five covering Dolores and San Miguel Rivers, Colo., with Paradox Valley quadrangle, 1928. 
(b) San Miguel River from mouth to Sawpit, 66 miles (9DK). Plan and profile, 1924. Scale, $1 \vdots 31,680$. Contour interval, 50 feet. Topography to 250-500 feet. Plan shown on one sheet. Not published.

(a) Green River (all of river within Colorado State), 42 miles (9BA, 9AK). Plan and profile by United States Geological Survey and United States Bureau of Reclamation, 1904 and 1922. Scale, 1:31,680. Contour interval, 20 feet on land, 5 feet on water. Topography to 200-300 feet. Published in 3 sheets (2 plan, 1 profile) ; part of map of Green River from Green River, Utah, to Green River, Wyo., published in 16 sheets (10 plan, 6 profile) by United States Geological Survey, 1924.

(b) Yampa River from sec. 14, T. 6 N., R. 86 W., to point in T. 1 N., R. 87 W., about 60 miles (9CA), and dam sites. Surveyed 1934-39. Scale, 1:31,680. Contour interval, 20 feet on land, 5 feet on water. Shows wide area of adjacent topography. Dam-site scale 1:4,800; contour interval 10 feet. Published in five plan sheets, 1947.

Pleasant Valley dam site, in sec. 21, 22, 27, 28, T. 5 N., R. 84 W. Topography to 189 feet.

Upper Stillwater dam site, at point about 16 miles above Yampa. Topography to 50 feet.

Intermediate dam site, at point about 14 miles above Yampa. Topography to 100 feet.

Middle Stillwater dam site, at point about 13 miles above Yampa. Topography to 50 feet.

Lower Stillwater dam site, at point about 11 miles above Yampa. Topography to 50 feet.

(b) Yampa River from mouth to sec. 32, T. 6 N., R. 93 W., 111 miles (9CB, 9CD). Plan and profile, 1922. Scale, 1:31,680. Contour interval, 20 feet on land, 5 feet on water. Topography to 100-200 feet. Published in five sheets (three plan, two profile). 1924.

The following dam sites were surveyed in 1922. Scale, 1:24,000. Contour interval, 10 feet. Out of stock.

Sand Draw dam site at mile 1.2. Topography to $\mathbf{1 7 0}$ feet.

Johnson's Draw dam site at mile 21.4. Topography to 200 feet.

Browns Draw dam site at mile 32. Topography to 260 feet.

(c) Morrison Creek from junction with Yampa River to sec. 25, T. 3 N., R. 84 W., about 10 miles (9CA). Topography detailed. Shown on one sheet, 1931-39 survey of Yampa River.

Morrison Creek dam site, in sec. 3, 10 T. 3 N., R. 84 W. Scale, $1: 4,800$. Contour interval, 10 feet. Topography to 200 feet.

(c) Little Snake River in Colorado and Wyoming, from sec. 6, T. 12 N., R. 91 W., Wyoming, to junction with North Fork, Colo., about 50 miles, 22 in Colorado, 28 in Wyoming (9CC), and dam site. Surveyed 1935-39. Scale, 1:31,680. Contour interval, 10 and 20 feet on land, 5 feet on water. Topography detailed. Published, 1947.

Three Forks dam site, in sec. 14, T. 12 N., R. 87 W. Scale, 1:4,800. Contour interval, 10 feet. Topography to 300 feet.

(c) Little Snake River from mouth to sec. 9 , T. 7 N., R. 98 W., 12 miles (9CC). Plan, 1922. Scale, 1:31,680. Contour interval, 20 feet on land, 5 feet on water. Topography to 20-100 feet. Published on one sheet, 1922 survey of Yampa River.

(d) Middle Fork Little Snake River from mouth to mile 3 (9CC). Shown in 1985-39 survey of Little Snake River.

Middle Fork dam site, in sec. 21, 22, 27, 28, T. 12 N., R. 86 W. Scale, $1: 4,800$. Contour interval, 10 feet. Topography to 360 feet. 
(d) North Fork Little Snake River from mouth upstream to Wyoming-Colorado State line, 1 mile (9CC). Shown on 1935-39 survey of Little Snake River.

Lower North Fork dam site, in sec. 16, T. 12 N., R. 86 W. Scale, 1: 4,800. Contour interval, 10 feet. Topography to 400 feet.

(d) South Fork Little Snake River from mouth to mile 12, in sec. 35, T. $11 \mathrm{~N}$, R. 87 W. (9CC). Dam-sites scale, 1:4,800; contour interval, 10 feet. Shown on 1935-39 survey of Little Snake River.

South Fork dam site, in sec. 20, 21, 28, 29, T. 12 N., R. 86 W. Topography to 250 feet.

Black Mountain dam site, in sec. 13, 14, T. 11 N., R. 87 W. Topography to 550 feet.

(d) Slater Creek from mouth to sec. 24, T. 10 N., R. 87 W., 30 miles (9CC), and dam sites. Dam-sites scale, 1:4,800; contour interval, 10 feet. Shown on 1935-39 survey of Little Snake River.

Walker dam site in sec. 6,7 , T. 10 N., R. 87 W., and sec. 1,12 , T. 10 N., R. $88 \mathrm{~W}$. Topography to 180 feet.

Columbus Mountain dam site, in sec. 5, T. 10 N., R. 87 W. Topography to 250 feet.

State Park, or Farmers dam site, in sec. $3,4,9,10$, T. 10 N., R. 88 W. Topography to 150 feet.

State dam site, in sec. 21 , T. 12 N., R. 89 W. Topography to 150 feet.

(a) San Juan River from Montezuma Creek in sec. 32 , T. 33 N., R. 2 W., to West Fork in sec. 12, T. 36 N., R. 1 W., New Mexico principal meridian, 32 miles (9GA), and dam site. Plan and profile, 1933-34. Scale, 1:31,680. Contour interval, 20 feet on land, 5 feet on water. Topography detailed. Published in three sheets (two plan, one profile), 1938.

Montezuma Creek dam site, in sec. 32 , T. 33 N., R. 2 W. Scale, $1: 4,800$.

Contour interval, 10 feet. Topography to 380 feet.

(a) San Juan River from sec. 22, T. 32 N., R. 4 W., to sec. 31, T. 33 N., R. 2 W., (9GA), 0.6 mile in New Mexico, 14.6 miles in Colorado. Plan, 1938-39. Scale, 1:31,680. Contour interval, 20 feet on land, 5 feet on water. Topography detailed. In preparation.

(a) San Juan River from Colorado-New Mexico State line (near Arboles) to sec. 22, T. 32 N., R. 4 W., New Mexico principal meridian, 11.4 miles (9GA). Arboles reservoir site. Plan by United States Bureau of Reclamation, 1933. Scale, $1: 12,000$. Contour interval 20 feet with 10-foot contours added in places. Topography detailed for Colorado portions of Arboles reservoir site. Map has been reduced to scale of $1: 31,680$ for incorporation and publication with San Juan River surveys described above. In preparation.

(b) Rio Blanco from mouth to mile 3 (9GA). Shown on two sheets (one plan, one profile), 1933-34 survey of San Juan River.

(b) Piedra River from mouth to sec. 21, T. 33 N., R. 5 W., New Mexico principal meridian, 8.5 miles (9GA). Surveyed by United States Bureau of Reclamation, 1933. To be published with 1933 survey of San Juan River.

(b) Piedra River from sec. 21, T. 33 N., R. 5 W., to sec. 6, T. 34 N., R. 4 W., New Mexico principal meridian, 15 miles (9GA). Plan, 1939. Scale, 1:31,680. Contour interval, 20 feet on land, 5 feet on water. Topography detailed for stretch immediately upstream from maximum flow line of Arboles reservoir site. In preparation.

(c) Devil Creek from mouth to sec. 8, T. 34 N., R. 4 W., New Mexico principal meridian, 2.8 mile (9GA). Shown on 1939 survey of Piedra River. In preparation.

$772100-48-3$ 
(o) Stollsteimer Creek from mouth to sec. 25, T. 34 N., R. 5 W., New Mexico principal meridian, 3 miles (9GA). Shown on 1939 survey of Piedra River. In preparation.

(b) Navajo River from mouth to sec. 13, T. 32 N., R. 3 W., New Mexico principal meridian, about 11/2 miles (9GA). Shown on 1938-39 survey of San Juan River described above. In preparation.

For areas in Colorado covered by United States Geological Survey standard topographic maps see plate 1 .

\section{CONNECTICUT}

Connecticut River between Hartford, Conn., and Holyoke, Mass. (1G). Plan by Corps of Engineers, United States Army, compiled from navigation surveys of 1903 and 1914 and from State, eity, town, and railroad maps. Surveys include preliminary map of Connecticut River from Hartford, Conn., to Holyoke, Mass., scale, 1 inch $=5$ miles (1913); profile of same section, scale, 1 inch $=20$ feet; plan showing Hartford dam site and lock and Enfield dam site and lock, scale $1: 7,200$, contour interval 5 and 10 feet, topography to 20-90 feet, with elevations in river bed shown; computations of water surfaces and water heights. Seven sheets (four plan, one profile, two computation), in report, Connecticut River between Hartford, Conn., and Holyoke, Mass., Sixty-fourth Congress, First session, House Document 417, 1915.

For areas in Connecticut covered by United States Geological Survey standard topographic maps see plate 1 .

\section{DELA W ARE}

For areas in Delaware covered by United States Geological Survey standard topographic maps see plate 1 .

\section{DISTRICT OF COLUMBIA}

Potomac RIver. See Virginia (p. 111).

For areas in District of Columbia and immediate vicinity covered by United States Geological Survey standard topographic maps see plate 1.

\section{FLORIDA}

For areas in Florida covered by United States Geological Survey standard topographic maps see plate 1 .

\section{GEORGIA}

Chattooga River from confluence with Tallulah River (to form Tugaloo River) upstream to Russell Bridge, S. C., 30 miles (2JB). Plan and profile, 1903. Scale, 1:24,000. Contour interval, 10 feet. Topography to 20-70 feet. Profile and elevations in Water-Supply Paper 115; elevations in Water-Supply Paper 197. Not published.

Tugaloo RIVER from confluence of Chattooga River and Tallulah River downstream to confluence with Seneca River (to form Savannah River), 46 miles. (2JB). Plan and profile, 1903. Scale, 1:24,000. Contour interval, 10 feet. Topography to 10-70 feet. Continues survey of Savannah River and certain tributaries from point where map of Tallulah River from mouth to Persimmon Creek leaves off to point where map of Savannah River from Tugaloo River to Broad River begins. Elevations in Water-Supply Paper 197. Not published. 
Tugaloo Rrver from confluence with Seneca River to Yonah Dam, about 43 miles (2JB). Plan by Corps of Engineers, United States Army, and United States Geological Survey, 1929-30. Scale, 1:24,000. Contour interval, 20 feet on land, 5 feet on river surface. Topography detailed to 700-foot contour above sea level. Shown on two sheets of 1929-30 survey of upper Savannah River Basin.

SavanNaH RIVER from mouth of Tugaloo River to a point about 1 mile downstream (2JC). Plan by Corps of Engineers, United States Army, and United States Geological Survey, 1929-30. Scale, 1:24,000. Contour interval, 20 feet on land, 5 feet on river surface. Topography detailed to 640-foot contour above sea level. Shown on part of one sheet of 1929-30 survey of upper Savannah River Basin, South Carolina and Georgia. The set was printed in 7 sheets for administrative use only.

SAVANNAE RIVER from confluence of Tugaloo River and Seneca River to Broad River, 42 miles (2JC). Plan and profile, 1903. Scale, 1:24,000. Contour interval, 10 feet. Topography to $10-70$ feet. Elevations in Water-Supply Paper 197. Not published.

SavannaH River from Broad River to Augusta, 54 miles (2JF, 2JH, 2JJ). Plan and profile, 1903. Scale, $1: 63,360$. Very little topography. Elevations in WaterSupply Paper 197. Not published.

(a) Tallulah River from confluence with Chattooga River (to form Tugaloo River) ùpstream to Persimmon Creek, 36 miles (2JB). Plan. Scale, 1:24,000. Contour interval, 10 feet. Topography to 20-70 feet. Profile and elevations in Water-Supply Paper 115; elevations in Water-Supply Paper 197. Not published.

(a) Broad River from mouth to Harrison Bridge, near Carnesville, 66 miles (2JD, 2JE). Plan and profile, 1903. Scale, 1:24,000. Contour interval, 10 feet. Topography to 20-50 feet. Profile in Water-Supply Paper 115; elevations in Water-Supply Paper 197.

(a) Broad River from a ferry about 0.3 mile upstream from mouth to North Fork Broad River, about 62 miles (2JE, 2JD). Plan by Corps of Engineers, United States Army, and United States Geological Survey, 1930. Scale, 1:24,000. Contour interval, 20 feet on land, 5 feet on river surface. Topography detailed to high-water contour of various reservoir sites. Shown on three sheets of 1929-30 survey of upper Savannah River Basin.

(b) North Fork Broad River from mouth to Bracket Bridge, about 10 miles (2JD). Plan by Corps of Engineers, United States Army, and United States Geological Survey, 1930. Scale, 1:24,000. Contour interval, 20 feet on land, 5 feet on river surface. Topography detailed to 640-foot contour above sea level. Shown on part of one sheet of 1929-30 survey of upper Savannah River Basin.

(c) Middle Fork Broad River from mouth to Thomason Bridge, about 14 miles (2JD). Plan by Corps of Engineers, United States Army, and United States Geological Survey, 1930. Scale, 1:24,000. Contour interval, 20 feet on land, 5 feet on river surface. Topography detailed to 640 -foot contour above sea level. Shown on part of one sheet of 1929-30 survey of upper Savannah River Basin.

(b) Hudson River from mouth to Wrights Bridge, about 17 miles (2JD). Plan by Corps of Engineers, United States Army, and United States Geological Survey, 1930. Scale, 1:24,000. Contour interval, 20 feet on land, 5 feet on river surface. Topography detailed to 640 -foot contour above sea level. Shown on part of one sheet of 1929-30 survey of upper Savannah River Basin.

(a) Little River from Raysville Bridge to Adams Creek, about 30 miles (2JG). Plan by Corps of Engineers, United States Army, and United States Geological Survey, 1930. Scale, 1:24,000. Contour interval, 20 feet on land, 5 feet on river surface. Topography detailed to 360-foot contour above sea level. Shown on one sheet of 1929-30 survey of upper Savannah River Basin.

Altamaha River. (2K). 
(a) Ocmulgee River, Juliette to Lloyd Shoals Dam, about 19 miles (2KF). Plan by Corps of Engineers, United States Army, and United States Geological Survey, 1930. Scale, 1:24,000. Contour interval, 20 feet on land, 5 feet on river surface. Topography detailed to high-water contours of various reservoir sites. Shown on two sheets of 1930-31 survey entitled Upper Altamaha River Basin, Ocmulgee and Oconee Rivers. Printed for administrative use only.

(b) South River, mouth to Flake Mill, about 39 miles (2KE). Plan by Corps of Engineers, United States Army, and United States Geological Survey, 1930-31. Contour interval, 20 feet on land, 5 feet on river surface. Topography detailed to high-water contours of various reservoir sites. Shown on three sheets of 1930-31 survey of Ocmulgee and Oconee Rivers.

(b) South River from Macon to Constitution, 107 miles (2KE, 2KF). Plan and profile, 1903. Scale, 1:24,000. Contour interval, 10 feet. Topography to 25-50 feet. Profile in Water-Supply Paper 115; elevations in Water-Supply Paper 197. Condensed plan and profile published in Twenty-second Annual Report, United States Geological Survey.

(b) Yellow River from mouth to Yellow River (village), 56 miles (2KE). Plan and profile, 1903. Scale, 1:24,000. Contour interval, 10 feet. Topography to about 50 feet. Small-scale profile in Water-Supply Paper 115; elevations in Water-Supply Paper 197.

(b). Yellow River, mouth to Porterdale, about 16 miles and Twin Wagon Bridge to Gloster Bridge, about 38 miles (2KE). Plan by Corps of Engineers, United States Army, and United States Geological Survey, 1930-31. Contour interval, 20 feet on land, 5 feet on river surface. Topography detailed to high-water contours of various reservoir sites. Shown on three sheets of 1930-31 survey of Ocmulgee and Oconee Rivers.

(b) Alcovy River from Newton-Jasper County line to Dickenson Bridge, about 37 miles (2KE). Plan by Corps of Engineers, United States Army, and United States Geólogical Survey, 1931. Contour interval, 20 feet on land, 5 feet on river surface. Topography detailed to high-water contours of various reservoir sites. Shown on three sheets of 1930-31 survey of Ocmulgee and Oconee Rivers.

(b) Alcovy River from mouth to Starrsville, 18 miles (2KE). Plan and profile, 1903. Scale, 1:22,500. Contour interval, 10 feet. Topography to about 50 feet. Profile in Water-Supply Paper 115; elevations in Water-Supply Paper 197.

(b) Towaliga River from mouth to High Falls Bridge, 22 miles (2 KF). Profile, 1903. Contour map of Towaliga River was destroyed by fire; profile and sketched plan without contours preserved. Elevations in Water-Supply Paper 197. Not published.

(b) Towaliga River, mouth to High Falls, nbout 20 miles (2KF). Plan by Corps of Engineers, United States Army, and United States Geological Survey, 1930. Contour interval, 20 feet on land, 5 feet on river surface. Topography detailed to high-water contours of two reservoir sites. Shown on two sheets of 1930 survey of Ocmulgee and Oconee Rivers.

(b) Oconee River, Greene-Hancock County line to McDonald Bridge, about 85 miles (2KA, 2KB). Plan by Corps of Engineers, United States Army, and United States Geological Survey, 1931. Scale, 1:24,000. Contour interval, 20 feet on land, 5 feet on river surface. Topography detailed to high-water contours of various reservoir sites. Shown on six sheets of 1930-31 survey of Ocmulgee and Oconee Rivers.

(b) Oconee River from Milledgeville to junction of North Fork and Middle Fork, 89 miles (2KA, $2 \mathrm{~KB}, 2 \mathrm{KC}$ ). Plan and profile by Corps of Engineers, United States Army, and United States Geological Survey, 1885 and 1902. Scale, 1:63,360. Elevations in Water-Supply Paper 197. Not published. 
(b) Middle Fork Oconee River from junction with North Fork to railroad bridge near Mulberry, 40 miles (2KA). Plan and profile, 1902. Scale, 1:63,360. Elevations in Water-Supply Paper 197. Not published.

(c) Middle Fork Oconee River, mouth to point approximately 1 mile upstream from Howard Bridge, about 24 miles (2KA). Plan by Corps of Engineers, United States Army, and United States Geological Survey, 1931. Scale, 1:24,000. Contour interval, 20 feet on land, 5 feet on river surface. Topography detailed to high-water contours of various reservoir sites. Shown on three sheets of 1930-31 survey of Ocmulgee and Oconee Rivers.

(b) Oconee River and Middle Fork Oconee River. Profile and projected plan without contours. Based on survey of section from Milledgeville to mouth of Apalachee River, by Corps of Engineers, United States Army, 1885, and of remaining section by United States Geological Survey, 1902. Not published.

(c) Mulberry River from mouth to Mulberry. Forks, 18 miles (2KA). Plan and profile, 1902. Scale, 1:63,360. Sketched plan projected from profile. Elevations in Water-Supply Paper 197. Map not published.

(c) Apalachee River from mouth High Shoals Bridge, 32 miles (2KA). Plan and profile, 1903. Scale, 1:63,360. No contours. Elevations in Water-Supply Paper 197. Map not published.

(c) Apalachee River, mouth to point approximately 1 mile upstream from mouth to Hard Labor Creek, about 12 miles, and Heads Mill Bridge to Carithers Mill, about 22 miles (2KA). Plan by Corps of Engineers, United States Army, and United States Geological Survey, 1931. Contour interval, 20 feet on land, 5 feet on river surface. Topography detailed to high-water contours of various reservoir sites. Shown on four sheets of 1930-31 survey of Ocmulgee and Oconee Rivers.

ChatTahoochee River (head of Apalachicola River) from Chattahoochee to Franklin, 65 miles (2RC). Plan and profile, 1903. Scale, 1:24,000. Contour interval, 10 feet. Topography to 50-100 feet. Not published.

Chattahoochee River from Franklin to West Point, 38 miles (2RD, 2RC). Plan and profile, 1903. Scale, 1:63,360. No contours shown in section from Franklin to Columbus. Not published.

Chattahoogher River from West Point to Columbus, 37 miles (2RE, 2RD). Plan and profile, 1903. Scale, 1:24,000. Contour interval, 10 feet. Topography to 50-100 feet. Not published.

Chattahooohez River from Santee to Chestatee River, 55 miles (2RA). Plan and profile, 1903. Scale, 1:24,000. Contour interval, 10 feet. Topography to 50-100 feet. Not published.

Chattahoochaie River from mouth of Chestatee River to Chattahoochee, 58 miles (2RB). Plan and profile, 1903. Scale, 1:63,360. No contours. Not published.

Chattahoochee RIver from mouth to Gainesville, 205 miles (2R). Small-scale profile ( 1 inch=16 miles) in report entitled "Water Powers of Georgia," published by Georgia Geological Survey, 1921.

ChatTahoochee RIVer from Columbus to Nacoochee, 250 miles (2R). Table of elevations in Water-Supply Paper 197.

(a) Soque River from mouth to Clarksville, 8 miles (2RA). Plan and profile, 1903. Scale, 1:24,000. Contour interval, 10 feet. Topography to $20-80$ feet. Small-scale profile in Water-Supply Paper 115; elerations in Water-Supply Paper 197.

(a) Chestatee River from mouth to Willow, 47 miles (2RA). Plan and profile, 1903. Scale, 1:24,000. Contour interval, 10 feet. Topography to 40-70 feet. Small-scale profile in Water-Supply Paper 115; elevations in Water-Supply Paper 197. 
(a) Flint River from Woodbury to Creek Agency Reserve, 45 miles (2SB). Plan and profile, 1900. Scale, 1:36,000. No topography. Elevations in WaterSupply Paper 197. Map not published.

Coosawatee River from Carters to Ellijay, 25 miles (2VG). Profile and sketched plan, 1900. Scale, 1:63,360. Small-scale profile published in Twentysecond Annual Report, United States Gelogical Survey, Part IV. Elevations in Water-Supply Paper 197.

(a) Dtowah River from Rome to Little River, 63 miles (2VF). Profile and sketched plan by Corps of Engineers, United States Army, 1879. Scale, 1:63,360. Elevations in Water-Supply Paper 197. Map not published.

(a.) Tallapoosa River from Tallapoosa to Alabama-Georgia State line, 3 miles (2VA). Profile and sketched plan 1904. Scale, 1:12,000 and 1:24,000. Part of map of river from Tallapoosa, Ga., to Matilda, Ala.

Mississippi River Basin (3).

(a) Ohio River (3).

(b) Tennessee River (3T).

(c) Hiwassee River from Hiwassee, Ga., to North Carolina-Georgia State line, 5 miles (3UJ), and to North Carolina-Tennessee State line. Plan and profile, 1903. Scale, 1:24,000. Contour interval, 10 feet. Topography to 50 feet. Elevations in Water-Supply Paper 197. Not published.

(d) Notteley River from Blairsville to North Carolina-Georgia State line, 20 miles (3UJ), showing river to mouth in North Carolina. Plan and profile, 1903. Scale 1:24,000. Contour interval, 10 feet. Topography to 40-70 feet. Small-scale profile in Water-Supply Paper 115; elevations in Water-Supply Paper 197.

(d) Toccoa River from Butts Bridge, near Dial, to Georgia-Tennessee State line, 36 miles (3UK). Plan and profile, 1903. Scale, 1:24,000. Contour interval, 10 feet. Topography to 50 feet. Elevations in Water-Supply Paper 115 and 197.

For areas in Georgia covered by United States Geological Survey standard topographic maps see plate 1 .

\section{HAW AII}

All the islands have been surveyed and the maps published. Scales 1:62,500 and $1: 31,680$. Contour interval, $10,25,50$ feet.

\section{IDAHO}

Great Salt Lake. (10H).

(a) Bear River from Riverdale in sec. 31, T. 14 S., R. 40 E., to Novene in sec. 3, T. 11 S., R. 43 E., 83 miles (10HC). Plan and profile, 1913 . Scale, 1: 31,680. Contour interval, 25 feet on land, 5 feet on water. Topography to 25-50 feet. Published in Water-Supply Paper 350.

(b) Malad River. (10HD).

(c) Devil Creek from sec. 18, T. 14 S., R. 36 E., to sec. 11, T. 13 S., R. 36 E., 10 miles (10HD), including dam sites and Deep Creek. Surveyed by United States Geological Survey in cooperation with the State of Idaho, 1938-39. Scale 1:31,680. Contour interval, 10 feet on land and water. Topography detailed. Dam-site scale, 1:2,400; contour interval, 5 feet. Published in three sheets (one plan, one profile, one dam site), 1940.

Dam site No. 1, at mile 7.1 in sec. 23, 24, T. 13 S., R. 36 E. Topography to 70 feet.

Dam site No. 2, at mile 7.8 in sec. 13, 24, T. 13 S., R. 36 E. Topography to 120 feet. 
Dam site No. 3, at mile 8.4 in sec. 13, T. 13 S., R. 36 E. Topography to 100 feet.

(c) Deep Creek from sec. 10, T. 14 S., R. 36 E., to sec. 21 , T. 14 S., R. 37 E., 8 miles $(10 \mathrm{HD})$, and dam site. Surveyed by United States Geological Survey in cooperation with the State of Idaho 1938-39. Scale, 1:31,680. Contour interval, 10 feet. Shown on 1938-39 survey of Devil Creek.

Dam site No. 1, in sec. 18, T. 14 S., R. 37 E. Scale, $1: 2,400$. Contour interval, 5 feet. Topography to 135 feet.

Mud LAKE Basin (12GJ).

(a) Camas Creek (12GJ).

(b) West Camas Creek from junction with Steel Creek in sec. 8, T. 13 N., R. 38 E., upstream 2 miles (12GJ), and dam site. Surveyed by United States Geological Survey in cooperation, with the State of Idaho, 1939. Scale, 1:12,000. Contour interval, 10 feet. Topography to 50-100 feet. Published in one sheet, 1944.

Steel Creek dam site, in sec. 8 , T. 13 N., R. 38 E. Scale, 1:4,800. Contour interval, 5 feet. Topography to 110 feet.

Big Lost River Basin (12GL).

(a) Big Lost River from point in unsurveyed sec. 20 , T. 7 N., R. 20 E., to North Fork in unsurveyed sec. 36, T. 7 N., R. 19 E., 3 miles (12GL), and dam site. Surveyed by United States Geological Survey in cooperation with the State of Idaho, 1940. Scale, 1:24,000. Contour interval, 20 feet on land, 5 feet on water. Topography detailed. Published in one sheet with dam site, 1942.

Wild Horse dam site, in unsurveyed sec. 20 , T. 7 N., R. 20 E. Scale, 1: 4,800. Contour interval, 10 feet. Topography to 150 feet.

(b) North Fork Big Lost River from junction with Big Lost River to point in unsurveyed sec. 16, T. 7 N., R. 19 E., 5 miles (12GL). Shown on 1940 survey of Big Lost River. Published in one sheet, 1942.

Burnt Creek dam site, in unsurveyed sec. 23 , T. 7 N., R. 19 E. Scale,

1:4,800. Contour interval, 10 feet. Topography to 150 feet.

LAVA SINKS BaSin (12GJ).

(a) Medicine Lodge Creek from a point near west boundary of sec. 17, T. 11 N., R. 34 E., upstream to a point in sec. 21 , T. 12 N., R. 33 E., 8 miles (12GJ)., and dam sites. Surveyed by United States Geological Survey in cooperation with the State of Idaho, 1939. Scale, 1:24,000. Contour interval, 20 feet. Topography to 100 feet. Dam-site scale, 1:4,800; contour interval, 5 feet. Published in one sheet, 1944.

Dam site in S1/2 sec. 7, T. 11 N., R. 34 E. Topography to 65 feet.

Dam site in NE1/4 sec. 3, T. 11 N., R. 38 E. Topography to 100 feet.

(b) Warm Creek from corner common to sec. $25,26,35,36$, T. 13 N., R. 32 E., upstream to point near west boundary of sec. 23 , T. 13 N., R. 32 E., 1.5 miles (12GJ), and dam site. Surveyed by United States Geological Survey in cooperation with the State of Idaho, 1939. Scale, 1:24,000. Contour interval, 20 feet. Topography to 80 feet. Published in one sheet, 1944.

Dam site in sec. 25,26 , T. 13 N., R. 32 E. Scale, 1:4,800. Contour interval, 5 feet. Topography to 65 feet.

Columbia RIVER (12).

(a) Kootenai River from point 1 mile below Moyie River, Idaho, to international boundary, Montana, 12 miles in Idaho, 99 miles in Montana (12AA, 12AB, 12AD, 12AE, 12AG), and dam site. Surveyed by United States Geological Survey, 1927, 1929, and 1934. Scale, 1:31,680. Contour interval, 20 feet on land, 5 feet on water. Topography detailed. Published in nine sheets (five plan, two profile, two dam sites). 
Katka dam site, in sec. 31 , T. 62 N., R. 3 E. Scale, 1:4,800. Contour interval, 20 feet. Topography to 420 feet.

(b) Moyie River from Highway bridge 11/2 miles above mouth to international boundary (12AH) and dam sites. Scale, 1:31,680. Contour interval 20 feet. Topography detailed. Dam-site scale, 1:4,800. Contour interval, 10 feet. Three sheets (two plan, one profile). In preparation.

Meadow Creek dam site at Mile 11. Topography to 2,600 feet above sea level.

Eileen Dam site at Mile 5. Topography to 2,300 feet above sea level.

(b) Moyie River from mouth to sec. 2, T. 63 N., R. 2 E., 11 miles (12AH). Plan by United States Forest Service, 1912. Scale, 1:15,840. Contour interval, 100 feet. Topography to 1,500 feet. Not published.

(a) Clark Fork and Pend Oreille River, including Pend Oreille Lake, from Horse Creek, Mont., in sec. 28, T. 27 N., R. 34 W., to Albany Falls, Idaho, in sec. 30, T. 56 N., R. 5 W., 4 miles in Montana, 73 in Idaho (12DG, 12DH, 12DJ, 12DM), and dam sites. Plan, 1926. Scale, 1:31,680. Contour interval, 5 feet. Topography to about 100 feet. Published in five sheets, 1927.

Albany Falls dam site on Pend Oreille River (formerly Clark Fork) near Albany Falls, Idaho (12DM). Scale, 1:4,800. Contour interval, 5 feet. Topography to 150 feet.

Albany Falls dam site. Scale, 1:1,300. Contour interval, 10 feet. Topography to $30-60$ feet.

(a) Pend Oreille Lake (12DH). Plan, 1926. Contour interval, 5 feet. Some underwater contours shown. Topography to 2,125 feet above sea level, or 75 feet above lake surface. Shown on two sheets, 1926 survey of Clark Fork and Pend Oreille River from Horse Creek, Mont., to Albany Falls, Idaho.

(a) Pend Oreille River (formerly Clark Fork) from international boundary, Washington, to Albany Falls, Idaho, in sec. 29, T. 56 N., R. 5 W., 75 miles (12DM, 12DN). Surveyed, 1934. Scale, 1:31,680. Contour interval, 20 feet on land, 1 foot and 5 feet on water. Topography detailed. Published in five sheets (three plan, two profile).

(a) Pend Oreille River (formerly Clark Fork) from Priest River, Idaho, to international boundary in Washington, 7 miles in Idaho, 72 in Washington (12DM, 12DN). Plan and profile, 1912. Scale, 1:31,680. Contour interval, 25 feet on land, 5 feet on water. Very little topography. Published in Water-Supply Paper 346.

(b) Clark Fork from St. Regis, Mont., to Pend Oreille Lake, Idaho, in sec. 4, T. 55 N., R. 2 E., 9 miles in Idaho, 120 in Montana (12DC, 12DD, 12DF, 12DG, 12DH). Plan and profile, 1911. Scale, 1:31,680. Contour interval, 25 feet on land, 5 feet on water. Very little topography. Published in Water-Supply Paper 346.

(b) Pack River from mouth to sec. 32, T. 59 N., R.1 W., Idaho, 29 miles (12DH). Plan, 1926. Scale, 1:31,680. Contour interval, 5 feet. Topography to about 60 feet. Shown on two sheets of 1926 survey of Clark Fork and Pend Oreille River from Horse Creek, Mont., to Albany Falls, Idaho.

(b) Priest River from mouth to Priest Lake in sec. 5, T. 59 N., R. 4 W., 44 miles (12DL), and dam sites. Plan and profile, 1934. Scale, 1:31,680. Contour interval, 20 feet on land, 5 feet on water. Topography detailed. Dam-site scale, 1:4,800, contour interval, 5 feet. Published in five sheets (two plan, 2 profile, one dam sites), 1937.

Dam site No. 1 , at mile 42.0 in sec. 7 , T. 59 N., R. 4 W. Topography to 80 feet.

Dam site No. 2, at mile 41.3 in sec. 13 , T. 59 N., R. 5 W. Topography to 75 feet. 
Dam site No. 3, at mile 40.7 in sec. 18 , T. 59 N., R. 4 W. Topography to 50 feet.

Dam site No. 4 , at mile 35.1 in sec. 31 , T. 59 N., R. 4 W. Topography to 70 feet.

Dam site No. 5, at mile 16.0 in sec. 8 , T. 57 N., R. 4 W. Topography to 110 feet.

Dam site No. 6, at mile 9.8 in sec. 29 , T. 57 N., R. 4 W. Topography to 185 feet.

(c) Lower West Fork Priest River from mouth to Moore Creek, sec. 5, T. 57 N., R. 5 W., 11 miles (12DL). Shown on 2 sheets (1 plan, 1 profile), 1934 survey of Priest River.

(a) Spokane River.

(b) Coeur d'Alene River from South Fork in sec. 31, T. 49 N., R. 2 E., to Jordan Creek, T. 53 N., R. 3 E., mile 59 (12EF), and dam sites. Plan and profile, 1934-36. Scale, 1:31,680. Contour interval, 20 feet on land, 5 feet on water. Topography detailed. Dam-site scale, 1:4,800; contour interval, 10 feet. Published in six sheets (four plan, two profile), 1938.

Enaville dam site, at mile 1.5, sec. 19, T. 49 N., R. 2 E. Topography to 240 feet.

Hultman dam site, at mile 4 , sec. 17 , T. 49 N., R. 2E. Topography to 120 feet.

Leland Glen dam site, at mile 19.5, sec. 25,26 , T. 50 N., R. 3 E. Topography to 260 feet.

Teddy Creek dam site, at mile 41, sec. 10, T. 51 N., R. 3 E. Topography to 240 feet.

Spion Kop dam site, at mile 50.2, sec. 8, T. 52 N., R. 3 E. Topography to 220 feet.

(c) North Fork Coeur d'Alene River from mouth to mile 12 in sec. 20, T. 50 N., R. 1 E. (12EF), and dam site. Shown on two sheets (1 plan, 1 profle), 1934-36 survey of Coeur d'Alene River.

Bumblebee dam site, at mile 3.8 in sec. 2 , T. 49 N., R. 1. E., and sec. 35 , T. 50 N., R. 1 E. Scale $1: 4,800$. Contour interval, 10 feet. Topography to 160 feet.

(c) Tepee Creek from mouth to mile 10, sec. 30, T. 52 N., R. 2 E. (12EF). Shown on two sheets (1 plan, 1 profile), 1934-1936 survey of Coeur d'Alene River.

(a) Snake River from Milner to Pine Creek in sec. 17, T. 2 N., R. 43 E., 243 miles (12GG, 12GJ, 12GL, 12GN, 12GP, 12GR), and dam sites. Surveyer by United States Geological Survey in cooperation with United States Bureau of Reclamation, 1910, 1920, 1932, and 1934-36. Scale, 1: 31,680. Contour interval, 10 and 20 feet on land, 5 feet on water. Topography in some sections shows only river banks, in others includes wide adjacent areas. Dam-site scale, 1: 4,800; contour interval 10 feet. Surveys combined in one set and published in 19 sheets (12 plan, 3 showing also dam sites, 7 profile), 1939.

(a) Snake River from Enterprise in sec. 16, T. 1 N., R. 3 W., to Minidoka in sec. 1, T. 9 S., R. 25 E., 242 miles (12HA, 12HC, 12GP, 12GR, 12GS). Plan and profile, 1912. Scale, 1:31,680. Contour interval, 25 feet on land, 5 feet on water. Topography varies. Published in Water-Supply Paper 347.

(a) Snake River from Lewiston, Idaho, in sec. 25, T. 36 N., R. 6 W., to Huntington, Oreg., in sec. 8, T. 14 S., R. 45 E., 187 miles (12HK, 12HN, 12HR). Plan and profile, 1920. Scale, 1: 31,680. Contour interval, 25 feet on land, 5 feet on water. Topography to $25-300$ feet. Published in 17 sheets (10 plan, 7 profile). Dam-site scale, $1: 4,800$, except as .noted. Contour interval, 10 feet.

Mountain Sheep Creek dam site, between miles 50 and 51. Topography to 170 feet. 
Corral Creek dam site, between miles 77 and 78. Topography to 350 feet.

Squaw Creek dam site, between miles 95 and 96 . Topography to 280 feet. 32 Point Creek dam site, between miles 112 and 113. Topography to 170 feet.

Nelson Creek dam site, between miles 120 and 121. Scale, 1:2,400. Topography to 90 feet.

(a) Snake River dam sites and power sites. Surveyed, 1921. Scale, 1:6,000, except as noted; contour interval, 10 feet, except as noted. Mileage refers to distance above Enterprise. Published in four sheets entitled Miscellaneous dam and power sites Snake River, Enterprise to Minidoka, Idaho.

Guffy dam site at mile 43.5. Topography to 50 feet.

Crocker dam site at mile 41. Topography to 90 feet.

Halls Ferry dam site at mile 66.3. Topography to 110 feet.

Crane Falls dam site at mile 72.4. Topography to 90 feet.

Dam site at mile 118.3. Topography to 80 feet.

Dam site at mile 124. Topography to 90 feet.

Dam site at mile 127.6. Topography to 120 feet.

Bickel Springs power site at mile 152 and 153 . No contours. Map shows location and elevation of springs for developing power.

Box Canyon power site at mile 156.3. Contour interval on water, 5 feet. No topography.

Kanoka Rapids dam site at mile 160. Scale, 14,800. Contour interval, 5 feet. Topography to 75 feet.

Clear Lakes power site at mile 161.2. Scale, $1: 4,800$. No topography.

Devils Washboard dam site at mile 162.4. Scale, 1:4,800. Contour interval, 5 feet. Topography to 40 feet.

Dam site at mile 165.2. Scale, 1:4,800. Contour interval, 5 feet. Topography to 20 feet.

Dry Creek dam site at mile 199.7. Scale, 1:2,400. Contour interval, 5 feet. Topography to 35 feet.

Black Canyon dam site, at mile 234.3 in sec. 13 , T. 3 N., R. 42 E. Topography to 220 feet.

Rush Beds dam site, at mile 222.8 in sec. 9 , T. 3 N., R. 41 E. Topography to 100 feet.

Eagle Rock dam site, at mile 68.4 in sec. 28 , T. 8 S., R. 30 E. Topography to 120 feet.

(b) Henrys Fork from St. Anthony in sec. 2, T. 7 N., R. 40 E., to sec. 33, T. 14 N., R. $44 \mathrm{E}$., 79 miles (12GH). Plan and profile, 1915. Scale, 1:31,680. Contour interval, 25 feet on land, 5 feet on water. Topography to 25-1,000 feet. Published in Water-Supply Paper 420.

(b) Henrys Fork from Junction with Snake River to St. Anthony, 32 miles (12GH). Plan and profile, 1934. Scale, 1:31,680. Contour interval, 20 feet on land, 5 feet on water. Shows only river channel and immediately adjacent banks. Shown on two sheets (one plan, one profile), 1910-36 survey of Stnake River from Milner to Pine Creek.

(c) Henrys Lake outlet from mouth to sec. 31, T. 16 N., R. 43 E., 22 miles (12GH). Plan and profile, 1915. Scale, 1:31,680. Contour interval, 25 feet on land, 5 feet on water. Topography to 100 feet. Published in Water-Supply Paper 420.

(b) Big Wood River from Konard Creek, 10 miles above Ketchum, Idaho, to Baker Creek, 6 miles (12GT) and dam site. Plan by United States Geological Survey in cooperation with the State of Idaho, 1941. Scale, 1:24,000. Contour interval, 20 feet on land (10-foot contours added in dashed lines), and 5 feet on water. Topography to $\mathbf{2 0 0}$ feet. Published in one sheet. 
Boulder Flats dam site on Big Wood River about mile 0.75 (12GT), Scale, 1: 4,800. Contour intervals, 10 feet on land, 1 foot on water. Topography to 250 feet.

(c) Warm Springs Creek from mouth, sections 11 and 14, T. 4 N., R. 17 E., Boise meridan, to Warfield Hot Springs, sec. 31, nine miles (12GT) and dam site. Plan by United States Geological Survey in cooperation with the State of Idaho, 1941. Scale, 1:24,000. Contour interval, 20 feet on land, 5 feet on water. Topography to 200 feet. Shown on one sheet with Big Wood River survey.

Guyer Hot Springs dam site, on Warm Springs Creek, sec. 15, T. 4 N., R. 17 E., Boise meridan (12GT). Topography to 400 feet.

(b) Bennett Creek from sec. 28, T. 2 S., R. 8 E., upstream 4 miles (12HA) and dam site. Surveyed by United States Geological Survey in cooperation with State of Idaho, 1939. Scale, 1:24,000. Contour interval, 20 feet. Topography to 100 feet. Published in one sheet, 1944 .

Dam site in SE1/4 sec. 9, T. 2 S., R. 8 E. Scale, 1:4,800. Contour interval, 5 feet. Topography to 75 feet.

(b) Boise River from backwater of Arrowrock reservoir in sec. 29, T. 4 N., R. 6 E., to junction of North Fork and Middle Fork, 12 miles (12HD), showing tributaries and dam sites. Plan and profile, 1927. Scale, 1:31,680. Contour interval, 50 and 100 feet on land, 5 feet on water. Topography to $200-400$ feet. Complete survey includes 39 miles on North Fork, 39 miles on Middle Fork, 92 miles on South Fork, and parts of minor tributaries. Shown on two sheets (one plan, one profile) in set of seven covering Boise River and tributaries.

Twin Springs dam site, at mile 20.5 in sec. 7,18 , T. 4 N., R. 7 E. Plan and cross section by United States Reclamation Service and United States Geological Survey, 1927. Scale, 1:4,800. Contour interval, 20 feet. Topography to 400 feet. Published in one sheet by United States Geological Survey.

(c) North Fork Boise River from mouth in sec. 4, T. 4 N., R. 7 E., upstream to sec. 3, T. 7 N., R. 10 E., 39 miles (12HD). Plan and profile, 1927. Scale, 1:31,680. Contour interval, 20,25 , and 100 feet on land, 5 feet on water. Topography to 200-300 feet. Shown on four sheets in set of 7, 1927 survey of Boise River and tributaries.

(c) North Fork Boise River (12HD). Dam sites. Plan and cross section by United States Reclamation Service and United States Geological Survey, 1927. Scale, 1:4,800. Contour interval, 10 feet. Published in one sheet by United States Geological Survey.

Upper Barber Flats dam site, at mile 13.6. Topography to 300 feet.

Lower Barber Flats dam site, at mile 13.3. Topography to 225 feet.

(c) Middle Fork Boise River from mouth to point 2 miles above Atlanta, 39 miles (12HD). Plan and profile, 1927. Scale, 1:31,680. Contour interval 25, 50, and 100 feet on land, 5 feet on water. Topography detailed. Shown on two sheets (one plan, one profile) in set of 7,1927 survey of Boise River and tributaries.

(c) Middle Fork Boise River (12HD) dam site. Plan and cross section by United States Reclamation Service and United States Geological Survey, 1927. Published in one sheet by United States Geological Survey.

Alexander Flats dam site, from mile 30.7 to mile 31.05 in sec. 24, T. 5 N.,

R. 7 E. Scale, 1:4,800. Contour interval, 10 feet. Topography to 300 feet.

(c) South Fork Boise River from backwater of Arrowrock reservoir in sec. 33, T. 3 N., R. 6 E., to 1 mile above Ross Fork, 92 miles (12HD) and dam sites. 
Plan and profile, 1927. Scale, 1:31,680. Contour interval, 25 and 100 feet on land, 5 feet on water. Topography to 200-300 feet. Dam-site scale, 1:4,800. Shown on four sheets in set of seven, 1927 survey of Boise River and tributaries.

Raspberry dam site, at mile 22.2 in sec. 30 , T. 2 N., R. 7 E. Contour interval, 25 feet on land, 5 feet on water. Topography to 300 feet.

Indian Point dam site, at mile 36.4 in sec. 8 , T. 1 S., R. 8 E. Contour interval, 20 feet on land, 5 feet on water. Topography to 165 feet.

Anderson Ranch dam site, at mile 43.2 in sec. 1, T. 1 S., R. 8 E. Contour interval, 10 feet. Topography to 300 feet.

Dog Creek dam site, at mile 61.7 in sec. 7, T. 2 N., R. 10 E. Contour interval, 10 feet. Topography to 150 feet.

Bascum Ranch dam site, at mile 75.5. Contour interval, 10 feet. Topography to 200 feet.

(d) Smoky Creek from mouth to point 5 miles upstream (12HD). Plan and profile, 1927. Scale, 1:31,680. Contour interval, 100 feet on land, 5 feet on water. Topography to $200-300$ feet. Shown on two sheets (one plan, one profile) in set of seven, 1927 survey of Boise River and tributaries.

(e) Little Smoky Creek from mouth to point 10 miles upstream (12HD). Plan and profile, 1927. Scale, 1:31,680. Contour interval, 20 and 100 feet on land, 5 feet on water. Topography to $40-300$ feet. Shown on two sheets (one plan, one profile) in set of seven, 1927 survey of Boise River and tributaries.

(b) Payette River from Horseshoe Bend, Idaho, to confluence of North Fork and South Fork, 15 miles (12HG), and tributaries above Horseshoe Bend. Plan and profile, 1924-25. Scale, 1:31,680. Contour interval, 20 feet. Topography detailed. Complete survey includes 41 miles on North Fork, 70 miles on South Fork, with dam sites; also parts of minor tributaries. Shown on two sheets in set of seven (four plan, three profile) covering Payette River and tributaries above Horseshoe Bend.

(c) North Fork Payette River from mouth to Cascade, 41 miles (12HG). Plan and profile, 1924. Scale, 1: 31,680. Contour interval, 20 feet. Topography detailed. Shown on two sheets (one plan, one profile) in set of seven, 1924-25 survey of Payette River and tributaries above Horseshoe Bend.

Cabarton dam' site, at mile 43.6 in sec. 36, T. 13 N., R. 3 E. Scale, 1:4,800. Contour interval, 10 feet. Topography to 150 feet. Shown on one sheet of map of miscellaneous dam sites in connection with map of Payette River above Horseshoe Bend.

(c) South Fork Payette River from mouth to point 8 miles above Canyon Creek, 70 miles (12HG). Plan and profile, 1924-25. Scale, 1:31,680. Contour interval, 20 feet. Topography detailed. Shown on 5 sheets in set of 7, 1924-25 survey of Payette River and tributairies above Horseshoe Bend.

Grandjean dam site, at mile 66.2.' Scale, 1:4,800. Contour interval, 10 feet. Topography to 250 feet. Shown on 1 sheet of map of miscellaneous dam sites in connection with map of Payette River above Horseshoe Bend, Idaho.

Garden Valley dam site No. 1 at mile 7.65 and No. 2 at mile 7.0. Scale, 1:4,800. Contour interval, 10 feet. Topography to 200 feet above water surface at site No. 1, and to $\mathbf{1 5 0}$ feet at site No. 2. Shown on one sheet of map of miscellaneous dam sites in connection with map of Payette River above Horseshoe Bend, Idaho.

(d) Canyon Creek from mouth upstream to sec. 15, T. 10 N., R. 10 E., 2 miles (12HG). Plan, 1925. Scale, 1:31,680. Contour interval, 20 feet. Topography detailed. Shown on one sheet in set of seven, 1924-25 survey of Payette River and tributaries above Horseshoe Bend. 
(d) Warm Springs Creek from mouth to Bush Creek in sec. 24, T. 10 N., R. 9 E., 3 miles (12HG). Plan, 1925. Scale, 1:31,680. Contour interval, 20 feet. Topography detailed. Shown on one sheet in set of seven, 1924-25 survey of Payette River and tributaries above Horseshoe Bend.

(d) Clear Creek from mouth to Cold Creek in sec. 1, T. 9 N., R. 7 E., $51 \frac{1}{2}$ miles (12HG). Plan and profile, 1925. Scale, 1:31,680. Contour interval, 20 feet. Topography detailed. Shown on one sheet in set of seven, 1924-25 survey of Payette River and tributaries above Horseshoe Bend.

(d) Deadwood River from mouth upstream to Deer Creek, 36 miles (12HG). Plan and profile, 1925. Scale, 1:31,680. Contour interval, 20 feet. Topography detailed. Shown on two sheets in set of seven, 1924-25 survey of Payette River and tributaries above Horseshoe Bend.

Lower Deadwood River dam site, at mile 24.4. Scale, 1:4,800. Contour interval, 10 feet. Topography to 150 feet. Shown on one sheet of map of miscellaneous dam sites in connection with map of Payette River above Horseshoe Bend, Idaho.

(e) Deer Creek from mouth at mile 36 Deadwood River to Deer Creek Summit, 5 miles (12HG). Plan, 1925. Scale, 1:31,680. Contour interval, 20 feet. Topography detailed. Shown on one sheet in set of seven, 1924-25 survey of Payette River and tributaries above Horseshoe Bend.

(d) Middle Fork Payette River from sec. 6, T. 10 N., R. 5 E., to point 46 miles above mouth, 31 miles (12HG). Plan and profile, 1929. Scale, 1:31,680. Contour interval, 20 feet on land, 5 feet on water. Topography detailed. Shown on two sheets in set of eight, 1929-30 survey of South Fork Salmon River and certain tributaries, and Middle Fork Payette River.

(d) Middle Fork Payette River from mouth to sec. 6, T. 10 N., R. 5 E., 15 miles (12HG). Plan and profile, 1924-25. Scale, 1:31,680. Contour interval, 20 feet. Topography detailed. Shown on two sheets in set of seven, 1924-25 survey of Payette River and tributaries above Horseshoe Bend.

(e) Anderson Creek from mouth to Deadwood Basin in sec. 24, T. 9 N., R. 4 E., 21/2 miles (12HG). Plan, 1925. Scale, 1:31,680. Contour interval, 20 feet. Topography detailed. Shown on one sheet in set of seven, 1924-25 survey of Payette River and tributaries above Horseshoe Bend.

(e) Silver Creek from mouth to upper Peace Valley in sec. 20, T. 12 N., R. 6 E., 8 miles (12HG). Plan and profile, 1929. Scale, 1:31,680. Contour interval, 20 feet on land, 5 feet on water. Topography detailed. Shown on two sheets, 1.929-30 survey of South Fork Salmon River and Middle Fork Payette River.

Peace Valley dam site, at mile 4.4. Scale, 1:4,800. Contour interval, 10 feet. Topography to 140 feet.

(b) Weiser River from point one mile below mouth of West Fork near Fruitvale in sec. 15, T. 17 N., R. 1 W., to junction of East Branch and West Branch in sec. 3, T. 19 N., R. 1 W., 22 miles, and from bridge 2 miles southeast of Cambridge in sec. 16, T. 14 N., R. 3 W., to bridge east of Cambridge in sec. 11, T. 14 N., R. 3 W., 1.9 miles (12HF), and dam site. Plan, 1936. Scale, 1:31,680. Contour interval, 20 feet on land and 5 feet on water. Topography detailed. In preparation.

Price Valley dam site in sec. 2, T. 19 N., R. 1 W. Scale 1:4,800. Contour interval, 5 feet. Topography to 60 feet.

(c) East Fork Weiser River from mouth upstream 0.9 mile and from sec. 30 , T. 17 N., R. 2 E., to sec. 31, T. 17 N., R. 2 E., 2 miles (12HF). The latter survey includes a 3-mile traverse to show canal route for diversion from East Fork to head of Mill Creek. Plan, 1936. Scale, 1: 31,680. Contour interval, 20 feet on land and 5 feet on water. Topography detailed. In preparation. 
(c) Warm Springs Creek from mouth in sec. 34, T. 18 N., R. 1 W., upstream 3.6 miles (12HF). Plan in 1936. Scale, 1:31,680. Contour interval, 20 feet on land and 5 feet on water. In preparation.

(c) West Fork Weiser River from mouth in sec. 15, T. 17 N., R. 1 W., to sec. 8, T. 18 N., R. 1 W., 9 miles (12HF). Plan, 1936. Scale, 1:31,680. Contour interval, 20 feet on land, 5 feet on water. In preparation.

(d) Lost Creek from mouth in sec. 8, T. 18 N., R. 1 W., to sec. 8, T. 19 N., R. 1 W., 12 miles (12HF), and dam site. Plan, 1936. Scale, 1:31,680. Contour interval, 20 feet on land and 5 feet on water. In preparation.

Lost Valley dam site in sec. 28, T. 19 N., R. 1 W., Scale, 1: 4,800. Contour interval, 5 feet. Topography to 80 feet. In preparation.

(c) Middle Fork Weiser River from sec. 8, T. 15 N., R. 2 E., to sec. 31, T. 17 N., R. 2 E., 10 miles, and dam site (12HF)? Plan, 1936. Scale, 1:31,680. Contour interval, 20 feet on land, 5 feet on water. In preparation.

Squaw Flat dam site in sec. 31, T. 17 N., R. 2 E., Scale, 1:4,800. Contour interval, 5 feet. Topography to 35 feet.

(c) Rush Creek from mouth in sec. 11, T. 14 N., R. 3 W., to West Coast Power Company plant in sec. 28 , T. 16 N., R. 3 W., 10 miles (12HF). Plan, 1936. Scale, 1:31,680. Contour interval, 20 feet on land, 5 feet on water. In preparation.

(c) Pine Creek from mouth in sec. 10, T. 14 N., R. 3 W., upstream 4.1 miles (12HF). Plan, 1936. Scale, 1:31,680. Contour interval, 20 feet on land, 5 feet on water. In preparation.

(c) Little Weiser River from a highway bridge in sec. 23, T. 14 N., R. 1 W., to Grouse Creek in sec. 35, T. 14 N., R. 1 E., 10 miles (12HF). Plan, 1936. Scale, $1: 31,680$. Contour interval, 20 feet on land, 5 feet on water. In preparation.

(c) Mann Creek from bridge on U. S. Highway 95 in sec. 24, T. 12 N., R. 5 W., upstream to sec. 15, T. 13 N'., R. 5 W., 7 miles (12HF), and dam sites. Plan, 1936. Scale, 1:31,680. Contour interval, 20 feet on land and 5 feet on water. Dam-site scale, $1: 4,800$. Contour interval, 10 feet. In preparation.

Brown dam site in sec. 27,34 , T. 13 N., R. 5 W., Topography to 210 feet. Spangler dam site in sec. 11, T. 12 N., R. $5 \mathrm{~W}$. Topography to 130 feet.

(c) Little Weiser River from mouth of Bull Gulch in sec. 5, T. 13 N., R. 1 E., upstream to mouth of Grouse Creek in sec. 35, T. 14 N., R. 1 E., 3 miles (12HF). Surveyed, 1939. Scale, 1:31,680. Contour interval, 20 feet. In preparation.

(b) Salmon River from sec. 36, T. 11 N., R. 13 E., upstream to sec. 1, T. 9 N., R. 13 E., 11 miles (12JA), showing Bear Valley and Stanley Basin, Idaho. Plan by United States Geological Survey, 1925. Scale, 1:31,680. Contour interval, 10 feet. Topography detailed. Published in two sheets. Out of stock.

(b) Salmon River from sec. 6, T. 21 N., R. 22 E. (Salmon) to sec. 34, T. 11 N., R. 13 E. (Stanley), 124 miles (12JA). Plan and profile, 1916, 1919, and 1924. Scale, $1: 31,680$. Contour interval, 25 feet on land, 5 feet on water. Topography to $100-400$ feet above water surface. Published in seven sheets (four plan, three profile).

(b) Salmon River from Little Salmon in sec. 15, T. 24 N., R. 1 E., to Salmon in sec. 6, T. 21 N., R. 22 E., 173 miles (12JC, 12JE, 12JG). Plan and profile, 1911. Scale, 1:31,680. Contour interval, 25 feet on land, כ feet on water. Topography to 100-200 feet above water surface. Published in Water-Supply Paper 347.

(b) Salmon River from mouth to Little Salmon River, sec. 15, T. 24 N., R. 1 E. (Riggins), 87 miles (12JJ). Plan and profile, 1912. Scale, 1:31,680. Contour interval, 25 feet on land and 5 feet on water. Topography, 100 to 200 feet above water surface. Published in Water-Supply Paper 347.

Dam site near Stanley at mile 122.4, sec. 25 and 36, T. 11 N., R. 13 E. Surveyed, 1925. Scale, 1:4,800. Contour interval, 10 feet. Topography 
to 400 feet. Published on one sheet, entitled Miscellaneous dam sites Bear Valley and Stanley Basin, Idaho. Out of stock.

(b) Salmon River. The following dam sites on Salmon River were surveyed in 1922, except McNabbs Point surveyed in 1924. Scale, 1:2,400. Contour interval, 10 feet. Published in 4 sheets entitled Miscellaneous dam sites Salmon River, Salmon to mouth; and at McNabbs Point near Challis, Idaho. Mileage for first 17 sites refers to distance below Salmon; mileage for remaining sites refers to distance below Riggins.

Dam site at mile 28. Topography to 100 feet above water surface.

Shoup dam site, at mile 40.8. Topography to 100 feet above water surface.

Dam site at mile 45. Topography to $\mathbf{1 0 0}$ feet above water surface.

Long Tom dam site, at mile 59.4. Topography to 180 feet above water surface.

Pinnacle dam site, at mile 62. Topography to 90 feet above water surface.

Proctor Fall dam site, at mile 65.4. Topography to 130 feet above water surface.

Horse Creek dam site, at mile 73.4 Topography to 140 feet above water surface.

Dam site at mile 78.3. Topography to $\mathbf{1 1 0}$ feet above water surface.

Black Canyon dam site, at mile 89.7. Topography to 220 feet above water surface.

Dillinger Creek dam site, at mile 96.2. Topography to 130 feet above water surface.

Rattlesnake dam site, at mile 99.6. Topography to 90 feet above water surface.

Growler dam site, at mile 111. Topography to $\mathbf{1 7 0}$ feet above water :surface.

Painted Rock dam site, at mile 118. Topography to 120 feet above water surface.

Castle dam site, at mile 127.6. Topography to 130 feet above water surface.

Crooked Bar dam site, at mile 136.5. Topography to 80 feet above water surface.

Rheims dam site, at mile 146.4. Topography to 120 feet above water surface.

Crevice dam site, at mile 160. Topography to $\mathbf{1 7 0}$ feet above water surface.

Poodle Dog diversion dam site, at mile 13 and mile 14. Topography to 120 feet above water surface.

Rhett Creek dam site, at mile 19.5. Topography to 100 feet above water surface.

Red Canyon dam site, at mile 41.7. Topography to 200 feet above water surface.

Green Canyon dam site, at mile 53.5. Topography to 140 feet above water surface.

Snow Hole dam site, at mile 63.5. Topography to 90 feet above water surface.

Section Line dam site, at mile 72. Topography to 80 feet above water surface.

Lower Canyon dam site, at mile 83 . Topography to 180 feet above water :surface. 
McNabbs Point dam site, at mile 57.3, in sec. 35, T. 15 N., R. 19 E. Surveyed by United States Geological Survey, 1924. Topography to 250 feet above water surface.

(c) Valley Creek from junction with Salmon River to source, 10 miles (12JA). Plan, 1925. Shown on two sheets, 1925 survey of Salmon River showing Bear Valley and Stanley Basin.

(c) Panther Creek from junction with Salmon River to Napias Creek. 20 miles (12JD). Plan and profile, 1930. Scale, 1:31,680. Contour interval, 20 feet. Topography detailed. Shown on two sheets in set of 7, 1930 survey of Middle Fork Salmon River and tributaries, and Panther Creek.

(d) Napias Creek from mouth upstream 3 miles (12JD). Plan and profile; 1930. Shown on one sheet, 1930 survey of Middle Fork Salmon River and tributaries and Panther Creek.

(c) Middle Fork Salmon River from mouth to Bear Valley Creek, 105 miles (12jD), and tributaries, and Panther Creek. Plan and profle, 1930. Scale, 1:31,680. Contour interval, 20 feet on land, 5 feet on water. Topography to 300 feet. Published in seven sheets (four plan, three profile).

Aparejo dam site on Middle Fork Salmon River, at mile 32.4, about 3 miles below junction of Camas Creek. Surveyed, 1930. Scale, 1:4,800. Contour interval, 20 feet. Topography to 400 feet above water surface. Shown on one sheet, 1930 survey of Middle Fork Sulmon River and tributaries, and Panther Creek.

(c) Middle Fork Salmon River (12JD).

Dam site on Middle Fork Salmon River just below junction of Bear Valley Creek and Marsh Creek. Surveyed, 1925. Scale, 1:4,800. Contour interval, 10 feet. Topography to 400 feet allove water surface. Publlsned in one sheet, entitled Miscellaneous dam sites, Bear Valley and Stanley Basin, Idaho. Out of stock.

(d) Bear Valley Creek from mouth to point about 12 miles upstream (12JD). Plan, 1925. Scale, 1:31,680. Contour interval, 10 feet. Topography detailed. Published in two sheets, 1925 survey of Salmon River showing Bear Valley and Stanley Basin. Out of stock.

(d) Pistol Creek from mouth upstream 3 miles (12JD). Plan and profile, 1930. Shown on one sheet, 1930 survey of Middle Fork Salmon River and tributaries. and Panther Creek.

(d) Marble Creek from mouth upstream 3 miles (12JD). Plan and profile, 1930. Shown on one sheet, 1930 survey of Middle Fork Salmon River and tributaries, and Panther Creek.

(d) Loon Creek from mouth upstream 14 miles (12JD). Plan and profile, 1930. Shown on one sheet, 1930 survey of Middle Fork Salmon River and tributaries, and Panther Creek.

(d) Camas Creek from mouth upstream to sec. 8, T. 17 N., R. 17 E., 15 miles (12JD). Plan and profile, 1930. Shown on one sheet, 1930 survey of MiddleFork Salmon River and tributaries and Panther Creek.

(d) Big Creek from mouth upstream to Monumental Creek, 24 miles (12JD). Plan and profile, 1930. Shown on one sheet, 1930 survey of Middle Fork Salmon River and tributaries, and Panther Creek.

(c) Little Salmon River from mouth to sec. 13, T. 19 N., R. 1 E., 40 miles (12JH). Plan and profile, 1911. Scale, 1:31,680. Contour interval, 25 feet on land, 5 feet on water. Topography to $100-100$ feet above water surface. Published in Water-Supply Paper 347.

(c) South Fork Salmon River from mouth to Tyndall Creek in sec. 1, T. 14 N., R. 6 E., 81 miles (12JF), and tributaries, and Middle Fork Payette River. Plan and profile, 1929-30. Scale, 1:31,680. Contour interval, 20 feet on land, 5 feet 
on water. Topography detailed. Published on five sheets, in set of eight covering South Fork Salmon River and tributaries and Middle Fork Payette River.

Reed dam site, at about mile 47.2 (12JF). Scale, 1:4,800. Contour interval, 10 feet. Topography to 250 feet.

(d) Tyndall Creek from mouth in sec. 1, T. 14 N., R. 6 E., upstream about 2 miles (12JF). Shown on one sheet, 1929-30 survey of South Fork Salmon River and tributaries, and Middle Fork Payette River.

(d) East Fork South Fork Salmon River from mouth to Meadow Creek, 29 miles (12JF). Plan and profile, 1929. Scale, 1:31,680. Contour interval, 20 feet on land, 5 feet on water. Topography detailed. Shown on two sheets, 192930 survey of South Fork Salmon River and tributaries, and Middle Fork Payette River.

(e) Johnson Creek from mouth to Pen Basin, 30 miles (12JF). Plan and profile, 1929. Scale, 1:31,680. Contour interval, 20 feet on land, 5 feet on water. Topography detailed. Shown on two sheets, 1929-30 survey of South Fork Salmon River and tributaries, and Middle Fork Payette River.

(d) Secesh River from mouth upstream to Benton, 25 miles (12JF). Plan and profile, 1929. Scale, 1:31,680. Contour interval, 20 feet on land, 5 feet on water. Topography detailed. Shown on two sheets, 1929-30 survey of South Fork Salmon River and tributaries, and Middle Fork Payette River.

Secesh dam site, at approximately mile 18.8 (12JF). Scale, 1:4,800. Contour interval, 10 feet. Topography to 200 feet.

(b) Clearwater River from Lewiston to junction of Middle Fork and South fork, 75 miles (12KB, 12KD), and tributaries. Plan and profile, 1924. Scale, 1:31,680. Contour interval, 20 feet on land, 5 feet on water. Topography detailed. Published in 14 sheets ( 7 plan, 7 profile), showing Clearwater River and tributaries, 1926.

Seven dam sites on Clearwater River were published on one sheet of map entitled Miscellaneous dam sites Clearwater River and tributaries.

Dam site, at mile 57.3 in sec. 36, T. 35 N., R. 2 E. Scale, 1:4,800. Contour interval, 10 feet. Topography to 165 feet. Published.

(c) Middle Fork Clearwater River from Kooskia to forks, 22 miles (12KB). .Plan and profile, 1924. Scale, 1:31,680. Contour interval, 20 feet on land, 5 feet on water. Topography detailed. Shown on 1924 survey of Clearwater River and tributaries.

Three Devils dam site, at mile 93.8 in sec. 2 , T. 32 N., R. 6 E. Scale, 1: 2,400. Contour interval, 10 feet. Topography to 240 feet. Published.

(d) Lochsa Fork from forks to Sand Creek, 70 miles (12KA). Plan and profile, 1924. Scale, 1:31,680. Contour interval, 20 feet on land, 5 feet on water. Topography detailed. Shown on 1924 survey of Clearwater River and tributaries.

Bright Angel Point dam site, at mile 19.3. Scale, 1:4,800. Contour interval, 10 feet. Topography to $\mathbf{4 6 0}$ feet. Published.

(d) Selway River from forks to Trapper Creek, 68 miles (12KA). Plan and profile, 1924. Scale, 1:31,680. Contour interval, 20 feet on land, 5 feet on water. Topography detailed. Shown on 1924 survey of Clearwater River and tributaries.

(c) South Fork Clearwater River from Kooskia to Golden, 49 miles (12KB). Plan and profile, 1924. Scale, 1:31,680. Contour interval, 20 feet on land, 5 feet on water. Topography detailed. Shown on 1924 survey of Clearwater River and tributaries.

South Fork dam site, at mile 9.5. Scale, 1:4,800, Contour interval, 10 feet. Topography to 160 feet. Published.

$772100-48-4$ 
(c) Lolo Creek from mouth upstream 4 miles (12KB). Plan and profile, 1924. Scale, $1: 31,680$. Contour interval, 20 feet on land, 5 feet on water. Topography detailed. Shown on 1924 survey of Clearwater River and tributaries.

(c) Orofino Creek from mouth upstream 4 miles (12KB). Plan and profile, 1924. Scale, 1:31,680. Contour interval, 20 feet on land, 5 feet on water. Topography detailed. Shown on 1924 survey of Clearwater River and tributaries.

(c) North Fork Clearwater River from mouth to Kelley Creek, 103 miles (12KC). Plan and profile, 1924. Scale, 1:31,680. Contour interval, 20 feet on land, 5 feet on water. Topography detailed. Shown on 1924 survey of Clearwater River and tributaries.

Bruce's Eddy dam site, at mile 2.0. Scale, 1:4,800. Contour interval,

10 feet. Topography to 230 feet. Published.

(c) Potlatch Creek from mouth upstream 9 miles (12KD). Plan and profile, 1924. Scale, 1:31,680. Contour interval, 20 feet on land, 5 feet on water. Topography detailed. Shown on 1924 survey of Clearwater River and tributaries.

(c) Lapwai Creek (12KD).

(d) Mission Creek from sec. 18 , T. 33 N., R. 3 W., upstream to sec. 6, T. 32 N., R. 2 W., 5 miles (12KD). Surveyed by United States Geological Survey in cooperation with Idaho State, 1939. Scale, 1:24,000. Contour interval, 20 feet. Published in one sheet, 1944.

Dam site on Mission Creek in NE $1 / 4$ sec. 25 , T. 33 N., R. 3 W. Scale, $1: 4,800$. Contour interval, 5 feet.

For areas in Idaho covered by United States Geological Survey standard topographic maps see plate 1 .

\section{ILLINOIS}

MississipPI RIVER from Cairo to St. Louis (5MA, 5MB, 5MF, 5MH). Plan and profile, surveyed at different dates. Topography detailed. Published in report by Board on Examination and Survey of Mississippi River, Sixty-first Congress, first session, House Document 50.

MississiPPI RIVer between Missouri River and Minneapolis. For report by Chief of Engineers, United States Army, see Seventy-second Congress, first session, House Document 137.

MississiPpi RIVER. Table of distances and elevations of Mississippi River along State of Illinois is shown in report, Water Resources of Illinois, published by Rivers and Lakes Commission of Illinois, 1914.

MISSISSIPPI RIVER from source to mouth has been surveyed for navigation and flood control by the Mississippi River Commission at different dates and with rarying topogràphic detail. For copies of maps apply to Mississippi River Commission, St. Louis, Mo.

(a) Ohio River from Cario, Ill., to Pittsburgh, Pa., 967 miles, surveyed for navigation by Corps of Engineers, United States Army, at different dates. Maps filed in district offices of Corps of Engineers.

(a) Ohio River. Table of distances and elevations of Ohio River along State of Illinois is shown in report, Water Resources of Illinois, published by Rivers and Lakes Commission of Illinois, 1914.

(b) Wabash River (30, 3P).

(c) Embarrass River from mouth to sec. 2, T. 9 N., R. 9 E., 110 miles (3OV, 3OU). Plan and profile by United States Geological Survey in cooperation with State of Illinois, 1910-11. Scale, 1:24,000. Contour interval, 5 feet. Topography detailed. Shows drainage possibilities. Out of stock. A table of distances and elevations is shown in report, Water Resources of Illinois, published by Rivers and Lakes Commission of Illinois, 1914. 
(d) North Fork Embarrass River from mouth to sec. 2, T. 9 N., R. 13 E., 35 miles (3OU). Plan and profile, 1910-11. Scale, 1:24,000. Contour interval, 5 feet. Topography detailed. Out of stock.

(c) Little Wabash River from Carmi to point 4 miles above Louisville, 115 miles (3PR, 3PP, 3PO). Plan and profile by Office of Experiment Stations, United States Department of Agriculture, 1907-08. Scale, 1:24,000. No contours. Flood line shown. Published in 11 sheets, supplement to report of Rivers and Lakes Commission of Illinois, 1911. Table of distances and elevations shown in report entitled "Water Resources of Illinois," published by Rivers and Lakes Commission of Illinois, 1914.

(d) Skillet Fork from mouth to Baltimore \& Ohio Southwestern Railway bridge, 92 miles (3PR). Plan and profile by Office of Experiment Stations, United States Department of Agriculture, 1907-8. Scale, $1: 24,000$. No contours. Flood line shown. Published in 11 sheets as a supplement to report of Rivers and Lakes Commission of Illinois, 1911. Table of distances and elevations shown in report entitled Water Resources of Illinois, published by Rivers and Lakes Commission of Illinois, 1914.

(a) Illinois River and Des Plaines River from Henry to Joliet, 100 miles (5KD, $5 \mathrm{KE}, 5 \mathrm{KH}, 5 \mathrm{KJ})$. Plan and profile by sanitary district of Chicago, 1894. Scale, $1: 63,360$. Contour interval, 10 feet. Topography detailed for several miles each side of rivers. Original map in files of sanitary district of Chicago. Table of distances and elevations from mouth of Illinois River to Joilet 289 miles, shown in report entitled "Water resources of Illinois," published by Rivers and Lakes Commission of Illinois, 1914.

The following surveys of reservoir sites were made in Illinois in $\mathbf{1 9 4 5}$ by the United States Geological Survey for the Corps of Engineers, United States Army. Scale, 1:24,000. Contour interval, 5 feet. The topography was carried to the proposed flow line of each site. This flow line together with the elevation of the water surface at the lower end of the survey is given after each site. The maps are not published, but prints can probably be obtained from the Chicago Office, Corps of Engineers, by paying for the cost of reproduction:

(a) Illinois River (5K, 5L).

(b) Fox River from sec. 3, T. 34 N., R. 4 E., to sec. 27 , T, 37 N., R. 7 E., third principal meridian $(5 K G)$. Flow line 580 feet. Water surface at dam site 500 feet. Shown on 4 sheets.

(b) Vermilion River from sec. 6, T. 32 N., R. 2 E., to sec. 26, T. 29 N., R. $4 \mathrm{E}$., third principal meridian $(5 \mathrm{KH})$. Flow line 595 feet. Water surface at dam site 475 feet. Shown on 5 sheets.

(b) Crow Creek from sec. 19, T. 29 N., R. 1 W., to sec. 30, T. 29 N., R. $1 \mathrm{E}$., third principal meridian (5KJ). Flow line 680 feet. Water surface at dam site 620 feet. Shown on 1 sheet.

(b) Mackinaw River from sec. 4, T. 25 N., R. 1 W., to sec. 6, T. 24 N., R. 5 E., third principal meridian (5LA). Flow line 710 feet. Water surface at dam site 616 feet. Shown on 11 sheets.

(b) Sangamon River from sec. 15, T. 20 N., R. 7 E., sec. 3, T. 22 N., R. $7 \mathrm{E}$., third principal meridian (5LE). Flow line 715 feet. Water surface at dam site 671 feet. Shown on 4 sheets.

(b) Sangamon River from sec. 33, T. 17 N., R. 3 E., to sec. 2, T. 19 N., R. $6 \mathrm{E}$., third principal meridian (5LE). Flow line 650 feet. Water surface at dam site 610 feet. Shown on 5 sheets.

(b) Sangamon River from sec. 25, T. 18 N., R. 2 W., to sec. 13, T. 15 N., R. $3 \mathrm{~W}$., third principal meridian (5LE). Flow line 540 feet. Water surface at dam site 485 feet. Shown on 9 sheets. 
(c) South Fork of Sangamon River from sec. 17, T. 15 N., R. 4 W., to sec. 18 , T. 12 N., R. 1 W., third principal meridian (5LE). Flow line 575 feet. Water surface at dam site 520 feet. Shown on 9 sheets.

(d) Flat Branch from sec. 19, T. 13 N., R. 2 W., to sec. 35, T. 13 N., R. 2 E., third principal meridian (5LE). Flow line 610 feet. Water surface at dam site 570 feet. Shown on 5 sheets.

(d) Sugar Creek.

(e) Lick Creek from sec. 25, T. 15 N., R. 6 W., to sec. 15, T. 14.N.,

R. 7 W., third principal meridian (5LE). Flow line 600 feet. Water surface at dam site 560 feet. Shown on 2 sheets.

(c) Spring Creek from sec. 32 , T. 16 N., R. 6 W., to sec. 5 , T. 15 N., R. $7 \mathrm{~W}$., third principal meridian (5LE). Flow line 585 feet. Water surface at dam site 554 feet. Shown on 2 sheets.

(c) Salt Creek from sec. 5 , T. 19 N., R. 3 E., to sec. 23, T. 21 N., R. 5 E., and North Fork of Salt Creek from mouth to sec. 33, T. 22 N., R. 4 E., third principal meridian (5LE). Flow line 705 feet. Water surface at dam site 680 feet. Shown on 6 sheets.

(c) Salt Creek from sec. 11, T. 19 N., R. 1 E., to sec. 17, T. 19 N., R. 2 E., third principal meridian (5LE). Flow line 665 feet. Water surface at lower end of survey 616 feet and at upper end 630 feet. This map does not show the complete reservoir site. Shown on 2 sheets.

(d) Kickapoo Creek from sec. 19, T. 21 N., R. 1 E., to sec. 33, T. 22 N., R. 2 E., third principal meridian (5LE). Flow line 685 feet. Water surface at dam site 623 feet. Shown on 2 sheets.

(d) Kickapoo Creek from sec. 34, T. 10 N., R. 6 E., to sec. 28, T. 10 N., R. 7 E., and Jubilee Creek from mouth to sec. 9, T. 10 N., R. 6 E., third principal meridian (5LE). Flow line 595 feet. Water surface at dam site 515 feet. Shown on 1 sheet.

(d) Sugar Creek from sec. 16, T. 21 N., R. 2 W., to headwaters of West Fork in secs. 27 and 28, T. 23 N., R. 2 W., and headwaters of Middle Fork in sec. 6 , T. 23 N., R. 1 W., third principal meridian (5LE). Flow line 625 feet. Water surface at dam site 570 feet. Shown on 4 sheets.

(b) Spoon Creek from sec. 27, T. 9 N., R. 2 E., to sec. 3, T. 11 N., R. 5 E., fourth principal meridian $(5 \mathrm{LB})$. Flow line 595 feet. Water surface at dam site 520 feet. Shown on 7 sheets.

(b) La Moine River from sec. 13, T. 4 N., R. 5 W., to sec. 11, T. 6 N., R. $6 \mathrm{~W}$., fourth principal meridian (5LF). Flow line 565 feet. Water surface at dam site 496 feet. Shown on 6 sheets.

(b) Kankakee River from mouth upstream about 15 miles (5KC). Plan by sanitary district of Chicago, 1894. Scale, 1:63,360. Contour interval, 10 feet. Topography detailed. Shown on 1894 survey of Illinois River between Henry and Joliet. Not published.

(b) Spoon River from mouth to London Mills, 70 miles (5LB). Profile by United States Geological Survey, 1911. Scale, 1 inch $=4$ miles. Unpublished map is a small drawing of profile of river based on United States Geological Survey Topographic maps. Table of distances and elevations shown in report entitled "Water Resources of Illinois," published by Rivers and Lakes Commission of Illinois, 1914.

(b) Sangamon River from sec. 6 , T. 19 N., R. 6 W., to sec. 23 , T. 15 N., R. 3 W., 65 miles (5LD). Plan and profile by United States Geological Survey, 190508, and 1922. Scale, 1:48,000. Contour interval, 10 feet. Topography detailed. Urainage and topography of whole valley shown. Out of stock.

(c). South Fork Sangamon River from mouth to sec. 27, T. 12 N., R. 2 W., 70 miles (5LD). Plan and profile, 1905-7 and 1922. Seale, 1:48,000. Contour 
interval, 10 feet. Topography detailed. Shown on 1905-22 survey Sangamon River. Out of stock.

(d) Flat Branch from mouth to sec. 35, T. 14 N., R. 1 E., 18 miles (5LD). Plan and profile, 1905-07 and 1922. Scale, 1:48,000. Contour interval, 10 feet. Topagraphy detailed. Shown on 1905-22 surveys of Sangamon River. Out of stock.

(d) Bear Creek from mouth to sec. 27, T. 12 N., R. 3 W., 9 miles (5LD). Plan and profile, 1905-7 and 1922. Scale, 1:48,000, Contour interval, 10 feet. Topography detailed. Shown on 1905-22 survey of Sangamon River. Out of stock.

(c) Sugar Creek from mouth to sec. 2 , T. 14 N., R. 5 W., 17 miles (5LD). Plan and profile, 1905-07 and 1922. Scale, 1:48,000. Contour interval, 10 feet. Topography detailed. Shown on 1905-22 survey of Sangamon River. Out of stock.

(a) Kaskaskia River from mouth to Cowden Bridge, 148 miles (5MC, 5MD, $5 \mathrm{ME})$. Table of distances and elevations shown in report entitled "Water Resources of Illinois," published by Rivers and Lakes Commission of Illinois, 1914.

(a) Big Muddy River from mouth to point 2 miles above Plumfield, 86 miles (5MG). Unpublished profile based on survey made under direction of United States Geological Survey, 1910. Table of distances and elevations shown in report entitled "Water Resources of Illinois," published by Rivers and Lakes Commission of Illinois, 1914.

For areas in Illinois covered by United States Geological Survey standard topographic maps see plate 1 .

\section{INDIANA}

MISSISSIPPI RIVER BASIN (3).

(a) Ohio River from Cairo, Ill., to Pittsburgh, Pa., 967 miles. Survey for navigation by Corps of Engineers, United States Army, at different dates. Maps filed in district offices of Corps of Engineers.

(b) Wabash River (3P, 30).

(c) Mississinewa River from mouth to Marion in T. 24 N., R. 8 E., 75 miles (3OC). Plan by United States Geological Survey in cooperation with State of Indiana, 1915. Scale, 1:24,000. Contour interval, 10 feet. Topography to 30-150 feet. 4 plan sheets. In preparation.

For areas in Indiana covered by United States Geological Survey standard topographic maps see plate 1 .

\section{IOWA}

MIssISSIPPI RIvER from source to mouth has been surveyed for navigation and flood control by the Mississippi River Commission at different dates and with varying topographic detail. For copies of maps apply to Mississippi River Commission, St. Louis, Mo.

Mississippi RIVER between Missouri and Minneapolis. For report by Chief of Engineers, United States Army, see Seventy-first Congress, first session, House Document 137.

(a) Missouri River from mouth to Three Forks, Mont., 2,551 miles. Plan by Corps of Engineers, United States Army, 1878-94. Scale, 1:63,360. No contours; topography indicated by hachures. Published in 93 sheets, including 9 index sheets, by Missouri River Commission, St. Louis, Mo.

For areas in Iowa covered by United States Geological Survey standard topographic maps see plate 1. 


\section{KANSAS}

MississipPi RIVER Basin $(6,7)$.

(a) Missouri River from mouth to Three Forks, Mont., 2,551 miles. Plan by Corps of Engineers, United States Army, 1878-1894. Scale, 1:63,360. No topography. Published in 93 sheets, including 9 index sheets, by Missouri River Commission, St. Louis, Mo.

(b) Kansas River (6R).

(c) Republican River. See Nebraska (p. 65).

(d) South Fork Republican River (6PK).

(e) Cleveland Run reservoir site in T. 2 S., R. 40 W., 0.5 mile (6PK). Plan. Scale, 1:4,320. Contour interval, 2 feet. Topography to 18 feet. Published in report Irrigation from reservoirs in western Kansas and Oklahoma, of Sixtysecond Congress, third session in Senate Document 1021.

(d) Beaver Creek from sec. 25, T. 5 S., R. 37 W., to sec. 20, T. 5 S., R. 36 W., 3 miles (6PN). Plan. Scale, 1:14,000. Contour interval, 5 feet. Topography to 30 feet. Published in report Irrigation from reservoirs in western Kansas and Oklahoma, by Sixty-second Congress, third session, in Senate Document 1021.

(a) Arkansas River (7B).

(b) Cimarron River and North Fork Cimarron River reservoir site in T. $30 \mathrm{~S}$., R. 35 W., 5 miles (7BA, 7BB, 7BC). Plan. Scale, $1: 18,000$. Contour interval, 5 feet. Topography to 25 feet. Published in report Irrigation from reservoirs in western Kansas and Oklahoma, by Sixty-second Congress, third session, in Senate Document 1021.

For areas in Kansas covered by United States Geological Survey standard topographic maps see plate 1 .

\section{KENTUCKY}

MISSISSIPPI RIVER BASIN (3).

(a) Ohio River from Cairo, Ill., to Pittsburgh, Pa., 967 miles. Surveyed for navigation by Corps of Engineers, United States Army, at different dates. Maps filed in district offices of Corps of Engineers.

(b) Tennessee River. For report by Chief of Engineers, United States Army, on the Tennessee River and tributaries in North Carolina, Tennessee, Alabama, and Kentucky, covering navigation, flood control, power development, and irrigation, see Seventy-first Congress, second session, House Document 328.

For areas in Kentucky covered by United States Geological Survey standard topographic maps see plate 1 .

\section{LOUISIANA}

MISSISSIPPI RIVER from source to mouth has been surveyed for navigation and flood control by the Mississippi River Commission at different dates and with varying topographic detail. For copies of maps apply to Mississippi River Commission, St. Louis, Mo.

(a) Red River from a point just above Colfax in sec. 35, T. 7 N., R. 4 W., to the Louisiana-Arkansas line (7MA). Plan, 1944. Scale, 1:31,680. Contour interval, 5 feet. Topography very detailed. Published in 19 sheets, 1946.

For areas in Louisiana covered by United States Geological Survey standard topographic maps see plate 1 .

\section{MAINE}

St. John River from St. Francis River to Hamlin, 66 miles (1AC). Plan by International Boundary Commission. Scale, 1: 12,000. Contour interval, 20 feet. 
Topography to 500 feet. Shown on 13 sheets in set of 61 published by International Boundary Commission.

(a) Southwest Branch St. John River from Little St. John Lake to boundary between Montmagny and Bellechasse Provincial Districts, Quebec, Canada (1AA). Plan by International Boundary Commission. Scale, 1:12,000. Contour interval, 20 feet. Topography to 50 feet in most of area. Shown on 11 sheets in set of 61 published by International Boundary Commission.

(a) St. Francis River from mouth to Lake Pohenagamuk, 45 miles (1AC). Plan and profle by International Boundary Commission. Scale, 1:12,000. Contour interval, 20 feet. Topography to 80-800 feet. Plan shown on 6 sheets in set of 61 published by International Boundary Commission. Profile not published.

ST. Crorx Rrver from source to Calais, 124 miles (1BA). Plan by International Boundary Commission. Scale, $1: 6,000,1: 12,000$, and $i: 24,000$. Contour interval, 10 feet. Topography to 1,000 feet. Published in 13 sheets, by International Boundary Commission.

St. CroIx RIVER and West Branch from mouth to Leweys Lake, 30 miles (1BA). Profile by State Water Storage Commission of Maine, about 1911. Scale, 11/4 inches $=10,000$ feet. Published in third annual report, Maine State Water Storage Commission, 1912.

(a) Monument Brook from source to mouth, 12 miles (1BA). Plan by International Boundary Commission. Scale, 1: 6,000. Contour interval, 10 feet. Topography to 50 feet. Shown on 3 sheets in set of 18 published by International Boundary Commission.

(a) Grand Lake, Spednik Lake, and North Lake (1BA). Surveyed by International Boundary Commission. Scale, 1:24,000. Contour interval, 10 feet. Topography to 500 feet. Shown on 4 sheets in set of 18 published by International Boundary Commission.

Union Rrver from Ellsworth to Great Pond, 34 miles (1BC), and certain ponds in its basin. Plan and profile, 1909. Scale, 1:24,000. Contour interval, 10 feet. Topography to 10-50 feet. Complete survey includes outlets of most of the lakes and ponds, and the dams at these outlets. Scale, 1:2,400. Published in five sheets (two showing plan and profile of river, three showing lakes, ponds, outlets, and dams).

Lakes, ponds, outlets, and dam shown on three sheets are: (1) Abrams, Scammon, and Molasses Ponds, and dams at their outlets, and dam on Webb Brook near Webb Pond outlet; (2) Alligator Lake, and Spectacle, and Rocky Ponds, and dams at their outlets; (3) former outlet of Branch Lake, and dam at present (1909) outlet; Great Pond, ard dam at its outlet; and dam at Green Lake outlet. Out of stock.

Penobscot Basin lakes and ponds. Surveyed, 1907, shown on three sheets: (1) Chamberlain, Telos, and Webster Lakes, and Round Pond, at scale 1: 48,000;

(2) Allagash, Baskahegan, First and Second Grand Lakes, at scale 1:48,000;

(3) Endless, Mattawamkeag, Pleasant, Schoodic, and Seboeis Lakes, at scale 1: 63,360. Published in Water-Supply Paper 279, 1912.

Penobscot River from Bangor to North Twin Lake, 91 miles (1BE, 1BG, 1BH, 1BJ). Plan and profile, 1904. Scale, 1:28,800. Contour interval, 20 feet on land, 1 foot on water. Topography, 20-120 feet. Published in Water-Supply Paper 279.

(a) West Branch Penobscot River from Chesuncook Lake to Ambejejus Lake, 25 miles (1BE). Plan and profile, 1906. Scale, 1:24,000. Contour interval, 20 feet on land, 1 foot on water. Very little topography. Published in Water-Supply Paper 279.

(a) West Branch Penobscot River from Chesuncook Lake to Seboomook, 29 miles (1BD). Plan and profile, 1905. Scale; 1:24,000. Contour interval 10 
feet on land, 1 foot on water. Very little topography. Published in Water-Supply Paper 279.

(a) East Branch Penobscot River from First Grand Lake to Medway, 46 miles (1BF). Plan and profile, 1908. Scale, 1:24,000. Contour interval 10 feet on land, 1 foot on water. Very little topography. Published in Water-Supply Paper 279.

(a) Mattawamkeag River from Penobscot River to North Bancroft, 33 miles (1BG). Plan and profile, 1907. Scale, 1:24,000. Contour interval, 10 feet on land, 1 foot on water. Very little topography. Published in Water-Supply Paper 279.

(a) Piscataquis River from Harland to Barrows Falls, 60 miles (1BH). Plan and profile, 1910. Scale, 1: 24,000. Contour interval, 5 feet. Topography to 5-25 feet. Published in $\mathbf{5}$ sheets, plan and profile on each. Out of stock.

(b) Sebec River from mouth to Sebec, 10 miles (1BH). Plan and profile, 1910. Scale, 1:24,000. Contour interval, 5 feet. Topography to 5-25 feet. Published in one sheet. Out of stock.

(c) Sebec Lake (1BH), and dam site at Lake outlet. Plan, 1910. Scale, 1:24,000. Contour interval, 5 feet. Topography to 25 feet. Dam-site scale, 1: 24,000. Published in one sheet. Out of stock.

(b) Pleasant River from mouth to Silver Lake, 24 miles (1BH). Plan and profile, 1910. Scale, 1:24,000. Contour interval, 5 feet. Topography to 15-25 feet. Published in two sheets, plan and profile on each. Out of stock.

(c) Silver Lake (1BH), and dam site at outlet. Plan, 1910. Scale, 1:24,000. Contour interval, 5 feet. Topography to 25 feet. Dam-site scale, 1:2,400; topography to 15 feet. Lake shown on part of one sheet. Out of stock.

(c) Houston Stream from mouth to Big Houston Pond, 6 miles (1BH). Plan and profile, 1910. Scale, 1:24,000. Contour interval, 5 feet. Topography to 1525 feet. Published in one sheet. Out of stock.

(d) Big Houston Pond (1BH), and dam site at outlet. Plan, 1910. Scale, 1:24,000. Contour interval, 5 feet. Topography to 25 feet. Dam site scale, 1: 2,400. Published in one sheet. Out of stock.

(b) Schoodic Stream from Schoodic Lake to mouth, 4 miles (1BH). Plan and profile, 1910. Scale, 1:24,000. Contour interval, 5 feet. Topography to 10-25 feet. Published on part of one sheet. Schoodic Lake shown in Water-Supply Paper 279.

KENNEBEC RIvEr from Moosehead Lake to Skowhegan, 83 miles (1CB). Plan and profile by United States Geological Survey in cooperation with State of Maine, 1903-4. Scale, 1:24,000. Contour interval 1, 10 and 20 feet. Topography to 20-80 feet. Published in six sheets (five plan, one profile). Out of stock. Small scale profile shown in Water-Supply Paper 198.

KenNeBec River from Skowhegan to Hallowell, 38 miles (1CE, 1CF). Plan and profile, 1903. Scale, 1:62,500. Contour interval, 10 and 20 feet. Plan from Skowhegan to Hallowell shown on standard topographic maps ; scale, 1: 62,500 ; contour interval, 20 feet. Profile from Hallowell to Moosehead Lake, one sheet. Out of stock. Small-scale profile shown in Water-Supply Paper 198.

(a) Moosehead Lake (1CB). Outline plan from surveys in 1900 and 1905. Scale, 1:63,360. Topography not shown. Part of lake is shown on topographic map to Moosehead quadrangle; scale, 1:62,500; contour interval, 20 feet.

(b) Moose River from Moosehead Lake to Brassua Lake, 3 miles (1CB). Plan, 1905. Scale, 1:15,840. Contour interval, 1, 10, and 20 feet. Topography to 20 feet. Published on part of one sheet. Out of stock.

(c) Holeb Pond (1CB). Plan by United States Geological Survey, 1906. Scale, 1:27,000. Contour interval, 10 feet. Topography to 10 feet. Published 
on part of one sheet. Out of stock. Shown also on Attean Pond topographic map; scale, 1:48,000. Contour interval, 20 feet.

(c) Attean Pond (1CB). Plan, 1906. Scale, 1:20,000. Contour interval, 5 feet. Topography to 15 feet. Published in one sheet. Out of stock. Most of pond also on Attean Pond topographic map; scale, 1: 48,000; contour interval, 20 feet.

(c) Wood Pond(1CB). Plan, 1905. Scale, 1:20,000. Contour interval, 5 feet. Topography to 10 feet. Published in one sheet showing also outlet; scale, $1: 2,000$; contour interval, 2 feet; topography at outlet, carried to 12 feet above water surface. Out of stock. Shown also on Attean Pond topographic map; scale, $1: 48,000$; Contour interval, 20 feet.

(c) Long Pond (1CB). Plan, 1906. Scale, 1:48,000. Contour interval, 20 feet. Topography to 20 feet. Published on part of one sheet. Out of stock.

(c) Brassua Lake (1CB), with dam site. Plan, 1905. Scale, 1:15,840. Contour interval, 5 feet. Topography to 25 feet. Published on part of one sheet, showing also dam site at outlet; scale, $1: 1,475$; contour interval, 2 feet.

(a) Roach River (1CB).

(b) Lower Roach Pond (1CB). Plan, 1906. Scale, 1:48,000. Contour interval, 10 feet. Topography to 20 feet. Published on part of one sheet, supplement to Water-Supply Paper 198 and 201. Out of stock.

(b) Middle Roach Pond (1CB). Plan, 1906. Scale, 1:48,000. Contour interval, 10 feet. Topography to 20 feet. Published on part of one sheet, supplement to Water-Supply Paper 198 and 201. Out of stock.

(a) Dead River from mouth to Chain of Ponds, 76 miles (1CC). Plan and jrofile, 1910. Scale, 1:24,000. Contour interval, 1 foot and 5 feet. Topography to 15-25 feet. Published on 6 sheets, plan and profile on each. Also shown are two dam sites at outlet of Greenbush Reservoir and one at outlet of Chain of Ponds. Scale, 1:2,400; contour interval, 2 feet. Long Falls on Dead River; scale, $1: 2,400$; contour interval, 2 feet. Shown on sheet 1 . Out of stock.

(b) South Branch Dead River from mouth upstream 11 miles (1CC), showing Twin Pond and dam site. Plan and profile, 1910. Scale, 1:24,000. Contour interval, 1 foot and 5 feet. Topography to 15-25 feet. Published in one sheet. Showing also Twin Pond and dam site at outlet, scale, 1: 2,400; contour interval, 2 feet; Topography to 20 feet. Out of stock.

(b) Flagstaff Lake (1CC). Plan, 1906. Scale, 1:48,000. Contour interval, 10 feet. Topography to 20 feet. Out of stock.

(b) West Carry Pond (1CC). Plan, 1906. Scale, 1:48,000. Contour interval, 10 feet. Topography to 20 feet. Published on part of one sheet, supplement to Water-Supply Paper 198 and 201. Out of stock.

(b) Spring Lake (1CC). Plan, 1906. Scale, 1:48,000. Contour interval, 10 feet. Topography to 20 feet. Published on part of one sheet. Out of stock.

(b) Spencer Stream from mouth upstream 9 miles (1CG). Plan and profile, 1910. Scale, 1:24,000. Contour interval, 1 foot and 5 feet. Topography to 10-20 feet. Published. Out of stock.

(c) Little Spencer Stream from mouth upstream 4 miles (1CC). Plan and profile, 1910. Scale, $1: 24,000$. Contour interval, 1 foot and 5 feet. Topography to 10-20 feet. Published on part of one sheet. Out of stock.

(b) Spencer Ponds (1CC). Plan, 1906. Scale, 1:63,360. Contour interval, 10 feet. Topography to 20 feet. Published on part of one sheet. Out of stock.

(a) Sandy River from mouth to Madrid, 61 miles (1CD). Plan and profile, 1910. Scale, 1:24,000. Contour interval, 1 foot and 5 feet. Topography to 10-25 feet. Published in five sheets, plan and profile on each. Clear Water Pond and outlet on tributary are shown on one sheet. Out of stock.

(a) Sebasticook River (1CE, 1CG). 
(b) Moose Pond (1CG). Plan, 1912. Scale, 1:24,000. Contour interval, 5 feet. Topography to 15 feet. Published in one sheet. Out of stock.

ANDroscogain RIVER from Brunswick to Umbagog Lake, 167 miles (1DB, 1DC). Plan and profile, 1906. Scale, $1: 24,000$. Contour interval, 20 feet. Topography to 20-240 feet. Published in 10 sheets; Brunswick to Livermore Falls, 56 miles, profile only, two sheets, remaining distance shown on eight sheets, plan and profile on each. Out of stock.

(a) Umbagog Lake (1DB). Surveyed, 1909. Scale, 1:48,000. Contour interval 5 feet. Topography to 10 feet. Published on part of one sheet. Out of stock.

(b) Rapid River from Umbagog Lake to point above Pond-in-River, 6 miles (1DB). Plan and profile, 1910. Scale, 1:12,000. Contour interval, 5 feet. Topography to 10-20 feet. Published on one sheet. Out of stock.

(c) Upper Richardson Lake and Lower Richardson Lake (1DB), with dam and outlet of lower lake. Plan, 1909. Scale, 1:48,000. Contour interval, 5 feet. Topography to 15 feet. Dam-site scale, 1:4,800. Published in two sheets: lakes on part of one, dam and outlet on another. Out of stock.

(d) Mooselookmeguntic Lake (1DB). Plan, 1909. Scale, 1:48,000. Contour interval, 5 feet. Topography to 10 feet. Dam-site scale, 1:4,800. Published on two sheets, lake one one, dam and outlet on part of another. Out of stock.

(e) Kennebago River from Rangeley River to Kennebago Falls, 12 miles (1DB), and outlet of Kennebago Lake. Plan and profile, 1910. Scale, 1:12,000. Contour interval, 5 feet. Topography to 10-20 feet. Outlet scale, 1:4,800; topography to 30 feet. Published on one sheet. Out of stock.

$(f)$ Kennebago Lake and Little Kennebago Lake (1DB). Plan, 1910. Scale, 1: 24,000. Contour interval, 5 feet. Topography to 20 feet. Published in one sheet. Out of stock.

(e) Rangeley River from Rangeley Lake dam to Kennebago River, 1 mile (1DB), shows outlet of Kennebago Lake and Kennebago River. Plàn and profile, 1910. Scale, 1:12,000. Contour interval, 5 feet. Very little topography. Published on one sheet. Out of stock.

(f) Rangeley Lake (1DB), and outlets. Plan, 1910. Scale, 1:24,000. Contour interval, 5 feet. Topography to 20 feet above water surface. Outlet scale, 1: 2,400, contour interval, 5 feet for 15 feet above water surface. Published in two sheets (one lake, one outlet). Out of stock.

Saco RIVER from mouth to Maine-New Hampshire State line, 81 miles (1DG, 1DE). Profile by Maine State Water Storage Commission, about 1910. Scale, about $3 / 4$ inch $=1$ mile. Published in second annual report, Maine State Water Storage Commission, 1911.

For areas in Maine covered by United States Geological Survey standard topographic maps see plate 1 .

\section{MARYLAND}

Susquehanna River. See Pennsylvania (p. 94).

Potomac River. See Virginia (p. 111).

MISSISSIPPT RIVER BASIN (3).

(a) Ohio River (3).

(b) Monongahela River (3B).

(c) Youghiogheny River from point 16 miles above Friendsville upstream 7 miles (3BJ), Youghiogheny River reservoir site No. 5, which extends up Little Youghiogheny River to Oakland. Plan and profile by Flood Commission of Pittsburgh, based on United States Geological Survey maps, 1910. Scale, 1:50,000. No topography. Published in report by Flood Commission of Pittsburgh, 1911. 
(c) Youghiogheny River from point 5.5 miles above Friendsville upstream 6 miles (3BJ), Youghiogheny River reservoir site No. 4. Plan and profile by Flood Commission of Pittsburgh, based on United States Geological Survey maps, 1910. Scale, 1:50,000. No topography. Published in report by Flood Commission of Pittsburgh, 1911.

(c) Youghiogheny River from point 1.5 miles above Friendsville upstream 2 miles (3BJ), Youghiogheny River reservoir site No. 3. Plan and profile by Flood Commission of Pittsburgh, based on United States Geological Survey maps, 1910. Scale, 1:50,000. No topography. Published in report by Flood Commission of Pittsburgh, 1911.

(c) Youghiogheny River from Pennsylvania-Maryland state line upstream 5 miles (3BJ), Youhiogheny' River reservoir site No. 2. Plan and profile by Flood Commission of Pittsburgh, based on United States Geological Survey maps, 1910. Scale, 1.: 50,000. No topography. Published in report by Flood Commis:sion of Pittsburgh, 1911.

For areas in Maryland covered by United States Geological Survey standard topographic maps see plate 1 .

\section{MASSACHUSETTS}

ConNeOTicuT RIVER (1G).

(a) Deerfield River from mouth to junction with East Branch, 62 miles (1GL). Profile compiled by Commission on Waterways and Public Lands, 1916-17. Scale, 1 inch $=5$ miles. Published in report on water resources of Massachusetts, by Commission on Waterways and Public Lands, 1918.

(a) Ware River (head of Chicopee River) from mouth to Smithville dam, 28 miles (1GM). Profile compiled by Commission on Waterways and Public lands, 1916-17. Scale, 1 inch $=5$ miles. Published in report on water resources of Massachusetts, by Commission on Waterways and Public Lands, 1918.

(a) Chicopee River from mouth to junction of Swift and Quaboag Rivers at Three Rivers, 18 miles (1GM). Profile compiled by Commission on Waterways and Public Lands, 1916-17. Scale, 1 inch $=5$ miles. Published in report on water resources of Massachusetts, by Commission on Waterways and Public Lands, 1918.

(b) Swift River from mouth to North Dana dam, 25 miles (1GM). Profile compiled by Commission on Waterways and Public Lands, 1916-17. Scale, 1 inch $=5$ miles. Published in report on water resources of Massachusetts, by Commission on Waterways and Public Lands, 1918.

(b) Quaboag River from mouth to East Brookfield, 27 miles (1GM). Profile compiled by Commission on Waterways and Public Lands, 1916-17. Scale, 1 inch $=5$ miles. Published in report on water resources of Massachusetts, by Commission on Waterways and Public Lands, 1918.

(a) Westfield River from mouth to confluence of East Branch and West Branch, 24 miles (1GN). Profile compiled by Commission on Waterways and Public Lands, 1916-17. Scale, 1 inch $=4$ miles. Published in report on water resources of Massachusetts, by Commission on Waterways and Public Lands, 1918.

(b) East Branch Westfield River from mouth to East Windsor Branch, 27 miles (1GN). Profile compiled by Commission on Waterways and Public Lands, 1916-17. Scale, 1 inch $=5$ miles. Published in report on water resources of Massachusetts, by Commission on Waterways and Public Lands, 1918.

(b) West Branch Westfield River from mouth to railroad bridge at Becket, 16 miles (1GN). Profile compiled by Commission on Waterways and Public Lands, 1916-17. Scale, 1 inch $=5$ miles. Published in report on water resources of Massachusetts by Commission on Waterways and Public Lands, 1918.

MERRTM ACK RIVER (1E). 
(a) Nashua River from Massachusetts-New Hampshire State line to junction of North Fork and South Fork, 23 miles (1EE). Profile compiled by Commission on Waterways and Public Lands, 1916-17. Scale, 1 inch $=5$ miles. Published in report on water resources of Massachusetts, by Commission on Waterways and Public Lands, 1918.

(b) South Branch Nashua River from mouth to Wachusett reservoir, 5 miles (1EE). Profile compiled by Commission on Waterways and Public Lands, 191617. Scale, 1 inch $=5$ miles. Published in report on water resources of Massachusetts, by Commission on Waterways and Public Lands, 1918.

(b) North Branch Nashua River from mouth upstream 17 miles (1EE). Profile compiled by Commission on Waterways and Public Lands, 1916-17. Scale, 1 inch $=5$ miles. Published in report on water resources of Massachussetts, by Commission on Waterways and Public Lands, 1918.

TaUnton RIvkR from tidewater to Salisbury Lake, 44 miles (1FD). Profile compiled by Commission on Waterways and Public Lands, 1916-17. Scale, 1 inch $=5$ miles. Published in report on water resources of Massachusetts, by Commission on Waterways and Public Lands, 1918.

For areas in Massachusetts covered by United States Geological Survey standard topographic maps see plate 1 .

\section{MICHIGAN}

For areas in southern Michigan covered by United States Geological Survey standard topographic maps see plate 1 .

\section{MINNESOTA}

Most river surveys in Minnesota were made by the United States Geological Survey in cooperation with the State of Minnesota. The maps were published by the State; small-scale maps in maps and profiles, and large-scale maps in Atlas of water resources of Minnesota, both of which form parts of a report entitled Water Resources of Minnesota, 1909-12; published by Minnesota State Drainage Commission, 1912. All maps in the following list are published in that report, except as noted.

LAKE SUPERIOR (4A).

(a) Pigeon River from Pigeon Bay to South Fowl Lake, 30 miles (4AA). Plan and profile. Scale, 1:12,000. Contour interval, 10 feet on land, 5 feet on water. Topography to 10-100 feet. Four sheets.

(a) Brule River from mouth upstream 7 miles (4AA). Plan and profile. Scale, 1:12,000. Contour interval, 20 feet on land, 10 feet on water. Topography to 60-200 feet. One sheet.

(a) Devil Tract River from mouth in sec. 13 T. 61 N. R. 1 E. to outlet of

Elbow Lake in sec. 34, T. 62 N., R. 1 E., 5 miles (4AA). Plan and profile. Scale, 1:12,000. Contour interval, 20 feet on land, 10 feet on water. Topography to 20-200 feet. One sheet.

(a) Cascade River from mouth upstream 7 miles (4AA). Plan and profile. Scale, $1: 12,000$. Contour interval, 20 feet on land, 10 feet on water. 'Topography to 20-100 feet: One sheet.

(a) Poplar River from mouth upstream 6 miles (4AA). Plan and profile. Scale, $1: 12,000$. . Contour interval, 20 feet on land, 10 feet on water. Topography to $100-200$ feet. One sheet.

(a) Temperance River from mouth upstream 5 miles (4AA). Plan and profile. Scale, 1:12,000. Contour interval, 20 feet on land, 10 feet on water; Topography to 20-100 feet. One sheet. 
(a) Cross River from mouth upstream 8 miles (4AB). Plan and profile. Scale, $1: 12,000$. Contour interval, 20 feet on land, 10 feet on water. Topography to 20-100 feet. One sheet.

(a) Manitou River from mouth upstream 5 miles (4AB). Plan and profile. Scale, 1:12,000. Contour interval, 20 feet on land, 10 feet on water. Topography to $40-160$ feet. One sheet.

(a) Baptism River from mouth upstream 9 miles (4AB). Plan and profile. Scale, 1:12,000. Contour interval, 20 feet on land, 10 feet on water. Topography to $20-160$ feet. One sheet.

(a) Beaver Bay River from mouth upstream 6 miles (4AB). Plan and profile. Scale, 1:12,000 Contour interval, 20 feet on land, 10 feet on water. 'Topography to 20-200 feet. One sheet.

(a) Gooseberry River from mouth upstream 3 miles (4AC). Plan and profile. Scale, 1:12,000. Contour interval, 20 feet on land, 10 feet on water. Topography to 20-100 feet. One sheet.

(a) St. Louis River from Scanlon to Norman, 149 miles (4AD, 4AE, 4AF). Plan and profile. Scale, 1:24,000. Contour interval, 10 feet on land, 1 foot on water. Topography to $20-50$ feet. Seven sheets.

(b) Cloquet River from mouth to Brimson, 70 miles (4AF). Plan and profile. Scale, 1:24,000. Contour interval, 10 feet on land, 1 foot on water. Topography to $20-50$ feet. Four sheets.

Nelson River and Lake WinNiPeg (Canada).

(a) Red River from international boundary to Lake Traverse, 455 miles $(50,5 P)$. Plan and profile by Bureau of Public Roads, United States Department of Agriculture. Scale of plan, $1: 53,000 ;$ profile, 1 inch $=10$ miles. No topography, but many elevations are given on plan. Published in Report on drainage and prevention of overflow in the valley of the Red River of the North, United States Department of Agriculture Bulletin 1017, 1922.

(b) Ottertail River from Phelps in sec. 34, T. 134 N., R. 41 W., to sec. 26 , T. 132 N., R. 44 W., 50 miles (5OB). Plan and profile. Scale, 1:12,000. Contour interval, 5 feet on land, 1 foot on water. Topography to about 50 feet. Seven sheets.

(c) Ottertail Lake, 4 miles (5OB). Plan. Scale, 1:24,000. Contour interval, 5 and 10 feet. Very little topography. One sheet.

(b) Wild Rice River from sec. 1, T. 144 N., R. 42 W., to sec. 31, T. 144 N., R. 48 W. 104 miles (5OH). Plan and profile. Scale, 1:12,000. Contour interval, 10 feet on land, 1 foot on water. Topography to 10-50 feet. Eight sheets.

(b) Red Lake River from Crookston to Red Lake, 143 miles (5PB). Plan and profile. Scale, $1: 24,000$. Contour interval, 10 feet on land, 1 foot on water. Very little topography. Six sheets.

(c) Upper Red Lake, 24 miles (5PA). Plan. Scale, 1:36,000. Contour interval, 5 feet. Very little topography. One sheet.

(c) Lower Red Lake, 24 miles (5PA). Plan. Scale, 1:36,000. Contour interval, 5 feet. Topography to about 20 feet. 1 sheet.

(b) Roseau River from international boundary to Roseau, approximately 50 miles (5PG). Plan, 1929-30. Scale, 1:31,680. Contour interval, 2 feet. Topography detailed, showing wide adjacent area. Published in 2 sheets for administrative use only.

(a) Winnipeg River and Lake of the Woods, Canada.

(b) Rainy River (5N).

(c) Birch River from mouth to sec. 23, T. 62 N., R. 11 W., 4 miles (5NA). Plan shown on map of Kawishiwi River and certain lakes. 
(c) Kawishiwi River and certain lakes, from sec. 29 , T. 62 N., R. 10 W., to T. 62 N., R. 11 W., 29 miles (5NA), showing short sections of Kawishiwi and Birch Rivers, and Birch, Farm Garden, and White Iron lakes. Plan. Scale, 1: 24,000. Contour intervals on land and water, 5 feet, except between Fall Lake and Garden Lake, 10 feet. Very little topography. One sheet.

(c) Vermilion River from Vermilion Lake in sec. 11, T. $63 \mathrm{~N} .$, R. $17 \mathrm{~W}$., to Crane Lake, 42 miles (5NB). Plan and profile. Scale, 1:24,000. Contour interval on land, 5 feet to foot of Chain of Lakes, 10 feet below foot of Chain of Lakes; on water, 5 feet. Topography to $20-50$ feet. Three sheets.

(c) Little Fork River from mouth to sec. 16, T. 62 N., R. 20 W., 122 miles (5ND). Plan and profile. Scale, 1:24,000. Contour interval, 10 feet on land, 1 foot on water. Topography to $20-90$ feet. 5 sheets.

(d) Sturgeon River from mouth in sec. 4, T. 62 N., R. 21 W., to sec. 34, T. 62 N., R. 21 W., 8 miles (5ND). Plan and profile. Topography to 10-80 feet. Shown on sheet 5 of Little Fork River.

(c) Big Fork River from mouth to sec. 32, T. 150 N., R. 25 W., 153 miles (5NE). Plan and profle. Scale, 1:24,000. Contour interval, 10 feet on land, 1 foot on water. Topography to 10-50 feet. Six sheets.

MISSIsSIPPI RIVER from source to mouth has been surveyed for navigation and flood control by the Mississippi River Commission at different dates and with varying topographic detail. For copies of maps apply to Mississippi River Commission, St. Louis, Mo.

MIssissipPI RIVER. A profile in Minnesota is shown in report, Water resources investigation of Minnesota, 1909-12, published by Minnesota State Drainage Commission, 1912.

MISSISSIPPI RIVER between Missouri River and Minneapolis. For report by Chief of Engineers, United States Army, see Seventy-second Congress, First session, House Document 137.

(a) Prairie River from mouth to Crooked Lake, 32 miles (5AB). Plan and profile. Scale, 1:12,000. Contour interval, 5 feet on land, 1 foot on water. Topography to 5-50 feet. Three sheets.

(a) Crow Wing River from mouth to Crow Wing; Dam above Shell River, 89. miles (5AD). Plan and profile. Scale, 1:12,000. Contour interval, 5 feet on land, 1 foot on water. Topography to $\mathbf{0}-50$ feet. Nine sheets.

(a) Rum River from mouth to Onamia, 141 miles (5AH). Plan and profile. Scale, 1:24,000. Contour interval, 10 feet on land, 1 foot on water. Topography to 50 feet. Six sheets.

(b) Mille Lacs Lake, 17 miles (5AH). Plan by United States Geological Survey, 1909. Scale, 1:36,000. Contour interval, 5 feet. Very little topography. Published in one sheet by Minnesota State Drainage Commission, 1912.

(a) Minnesota River from mouth to Big Stone Lake, 339 miles (5BA, 5BB, 5BC, 5BD, 5BE, 5BF). Surveyed by Corps of Engineers, United States Army, 1909-10. Scale, 1 inch $=8$ miles. Small-scale profile shown in Maps and profiles: section of report entitled "Water Resources Investigation of Minnesota, 1909-12," published by Minnesota State Drainage Commission, 1912.

(a) St. Croix River. See Wisconsin (p. 130).

(a) Cannon River from mouth to Faribault, 60 miles (5CE). Plan and profile. Scale, 1: 24,000. Contour interval, 10 feet on land, 1 foot on water. Topography to $\mathbf{4 0}$ feet. Three sheets.

(b) Straight River from mouth upstream 2 miles (5CE). Very little topography. Shown on sheet 3 of Cannon River survey.

(a) Zumbro.River, including North Branch, Middle Branch, and South Branch, from Griffiths Lake to point on South Branch 4 miles above Middle Branch. Plan and profile. Scale, 1:24,000. Contour interval, 20 feet on land except where 
noted, 1 foot on water. Topography to $20-70$ feet. Four sheets (North Branch shown on sheet 3, Middle Branch on sheet 4, South Branch on sheets 3 and 4).

(a) Root River from mouth to point 8 miles above Chatfield, 107 miles (5DA). Plan and profile. Scale, 1:24,000. Contour interval, 5 and 10 feet on land, 1 foot on water. Topography to 5-30 feet. Five sheets.

For areas in Minnesota covered by United States Geological Survey standard topographic maps see plate 1.

\section{MISSISSIPPI}

MIssISSIPPI RIVER from source to mouth has been surveyed for navigation and flood control by the Mississippi River Commission at different dates and with varying topographic detail. For copies of maps apply to Mississippi River Commission, St. Louis, Mo.

MOBILE RTVER (2W).

(a) Tombigbee River from Fulton to Columbus, 108 miles (2XA, 2XC, 2XD). Plan and profile, 1908. Scale, 1: 12,000. No topography. Seven sheets, plan and profile on each. Not published.

Pearl River from Edinburg to sec. 17, T. 11 N., R. 10 E., 31/2 miles (2ZA), and from Boston Branch in sec. 25, T. 1 N., R. 1 E., to Gatesville in sec. 20, T. 2 N., R. 1 E., 12 miles (2ZC, 2ZD). Plan by United States Geological Survey and Mississippi Geological Survey, 1923. Scale, 1:24,000. Contour interval, 10 feet. Topography to 20-50 feet. Published by United States Geological Survey in 1 sheet, supplement to the Florence topographic map. Out of stock. Small-scale (1: 62,500) plan published as part of Florence topographic map.

(a) Strong River from sec. 11, T. 10 N., R. 21 W., to sec. 14, T. 2 N., R. 4 E., about 25 miles (2ZD). Plan by United States Geological Survey and Mississippi Geological Survey, 1923. Scale, 1:24,000. Contour interval, 10 feet. Topography to 20-80 feet. Published in one sheet by United States Geological Survey.

For areas in Mississippi covered by United States Geological Survey standard topographic maps see plate 1 .

\section{MISSOURI}

MISSISSIPPI RIVER from source to mouth has been surveyed for navigation and flood control by the Mississippi River Commission at different dates and with varying topographic detail. For copies of maps apply to Mississippi River Commission, St. Louis, Mo.

MIssissipPt RIVER between Missouri River and Minneapolis. For report by Chief of Engineers, United States Army, see Seventy-second Congress, first session, House Document 137.

(a) Missouri River from mouth to Three Forks, Mont., 2,551 miles, of which 597 miles is in Missouri $(6 R, 6 S)$. Plan based on various surveys, by Corps of Engineers, United States Army, 1878-94. Scale, $1: 63,360$. No contours. Topography indicated by hachures. Published in 93 sheets, including 9 index sheets, by Missouri River Commission, St. Louis, Mo.

(b) Gasconade River from Arlington to Rich Fountain, 53 miles (6S). Plan and profile by State of Missouri Bureau of Geology and Mines in cooperation with United States Geological Survey, 1922. Scale, $1: 15,480$. Contour interval, 10 feet. Topography to $\mathbf{1 0 0 - 1 5 0}$ feet. Published in five sheets (four plan, one profile), 1923. Out of stock.

(a) White River (7H).

(b) Current River from Jacks Fork to Van Buren, 33 miles (7HC). Plan and profile by State of Missouri Bureau of Geology and Mines in cooperation with United States Geological Survey, 1924-25. Scale, 1:12,000. Contour interval, 
20 feet. Topography detailed. Published in six sheets (five plan, one profile), 1925.

For areas in Missouri covered by United States Geological Survey standard topographic maps see plate 1 .

\section{MONTANA}

Mississippi River Basin (6).

(a) Red Rock River (head of Missouri River) from sec. 32, T. 13 S., R. 6 W., to sec. 13, T. 14 S., R. 1. W., 45 miles (6AA). Plan, 1923. Scale, 1: 126,720. Flow lines of proposed reservoir are shown by four contour lines. Not published.

(a) Missouri River from Great Falls to Three Forks, T. 2 N., R 2 E., 209 miles (6B). Plan and profile, 1913. Scale, 1:31,680. Contour interval, 25 feet on land, 5 feet on water. Topography to $25-400$ feet. Published in Water-Supply Paper 367.

(a) Missouri River from Fort Benton to State boundary, 520 miles $(6 \mathrm{~B}, 6 \mathrm{C}$, 6E). Plan by Corps of Engineers, United States Army, 1891. Scales, 1:7,200 and $1: 12,000$. Contour interval, 20 feet. Topography to 100-500 feet. From Fort Benton to mouth shown on 1878-94 survey of Missouri River from mouth to Three Forks, Mont.; see under State of Missouri.

(b) Madison River from sec. 6, T. 2 S., R. 2 E., to sec. 35, T. 11 S., R. 2 E., 78 miles (6AL). Reconnaissance survey : plan and profile, 1923. Scale, 1:63,360. Contour interval, 20 feet. Topography to 20-220 feet, at potential power sites only. Three sheets. Not published.

(b) Jefferson River (6AH).

(c) Beaverhead River (6AC).

(d) Ruby River from Ramshorn Creek to sec. 7, T. 8 S., R. 4 W., 36 miles (6AD), and dam site. Plan and profile, 1934. Scale, $1: 31,680$. Contour interval, 20 feet on land, 5 feet on water. Topography detailed. Published in three sheets (one plan, two profile showing dam site), 1937.

Ruby River dam site, at mile 24.2 in sec. 8 , T. 7 S., R. 4 W. Scale, 1: 4,800. Contour interval, 10 feet. Topography to 200 feet.

(d) Ruby River from sec. 8, T. 7 S., R. 4 W., to sec. 36 , T. 7 S., R. 5 W., 5 miles (6AD), and potential reservoir site. Plan, 1923. Scale, 1:31,680 Contour interval, 20 feet. Not published. Diagram of reservoir site shown in United States Geological Survey Twelfth Annual Report.

(d) Big Hole River from sec. 2, T. 5 S., R. 8 W., to sec. 34, T. 1 N., R. 11 W., 45 miles (6AG). Plan, 1923. Scale, $1: 126,720$ Contour interval, 20 feet. Small amount of topography shown, mainly in T. 4 S., R. 8,9 W., T. 5 S., R. 8 W., T. 1 S., R. $10 \mathrm{~W}$. Not published.

(b) Sun River (6BK).

(c) North Fork Sun River (6BK).

(d) North Fork North Fork Sun River from South Fork North Fork upstream 7 miles (6BK), reservoir site No. 3. Plan, 1905. Scale, 1:12,000. Contour interval, 10 feet. Out of stock.

(b) Judith River from mouth to Big Spring Creek, 64 miles (6CD). Plan and profile, 1931. Complete survey includes 64 miles on Judith River, 25 miles on Warm Spring Creek, 31 miles on Big Spring Creek, and Hanover dam site. Scale, 1:31,680. Contour interval, 20 feet on land, 5 feet on water. Topography detailed. Published in four sheets (two plan, two profile), Judith River shown on three sheets; dam site on one sheet, 1933.

(c) Warm Spring Creek from mouth to Warm Springs in sec. 19, T. 17 N., R. 18 E., 25 miles (6CD). Plan and profile, 1931. Scale, 1:31,680. Contour interval, 20 feet on land, 5 feet on water. Published on three sheets in set of four, covering Judith River, Warm Spring Creek, and Big Spring Creek. 
(c) Big Spring Creek from mouth to Big Springs in sec. 5, T. 14 N., R. 19 E., 31 miles (6CC). Plan and profile, 1931. Scale, 1:31,680. Contour interval, 20 feet on land, 5 feet on water. Published on 2 sheets in set of 4, 1931 survey of Judith River, Warm Spring Creek, and Big Spring Creek.

Hanover dam site on Big Spring Creek near town of Hanover in sec. 27, T. 16 N., R. 17 E., (6CC). Scale, 1: 4,800 feet. Contour interval, 10 feet. Topography to 70 feet.

(b) Musselshell River from mouth to sec. 32 ,T. 10 N., R. 31 E., 125 miles (6CH, 6CJ). Plan by United States Geological Survey, 1922. Scale, 1:63,360. Very little topography. Four sheets. Not published.

(c) Powder River from Wyo.-Mont. State line to Moorhead dam site in 'T. 9 S., R. 48 W., about 6 miles (6GE). This is part of Moorhead Reservoir site which extends into Wyo. Plan, 1947. Scale, 1:12,000. Contour interval, 10 feet with 5-foot contours shown by dotted lines in flat areas. Topography to 200 feet. In preparation.

(b) Yellowstone River (6G).

(c) Powder River from sec. 19, T. 9 S., R. 48 E., to north line of sec. 22, T. 2 N., IR. 54 W., 1241/2 miles (6GE, 6GF). Plan by Ùnited States Geological Survey and United States Bureau of Reclamation, 1945-46. Scale, 1:24,000. Contour interval 10 feet on land with occasional 5-foot contours shown by broken lines. Topography detailed. Published by United States Geological Survey in six sheets, 1948.

(b) Little Missouri River from Montana-Wyoming State line to MontanaSouth Dakota State line (6.JC). Part of a survey extending from 10 miles south of Montana-Wyoming line to Marmarth, N. Dak. Plan by United States Geological Survey and United States Bureau of Reclamation, 1945-47. Scale, 1:24,000. Contour interval, 5 feet in Montana. In preparation.

Columbia River Basin (12A, 12B, 12C, 12D).

(a) Kootenai River from point 1 mile below Moyie River, Idaho, in sec. 22, T. 62 N., R. 2 E., to international boundary, Montana, 111 miles (12AA, 12AB, 12AD, 12AE, 12AG), and dam sites. Plan and profile, 1927, 1929, and 1934. Scale, 1:31,630. Contour interval, 20 feet on land, 5 feet on water. Topography detailed. Dam-site scale, 1:4,800; contour interval, 10 feet. Published in nine sheets (five plan, two profile, two dam sites), 1938.

Tunnel No. 8 dam site, at mile 14 in sec. 28 , T. 33 N., R. 34 W. Topography to 330 feet.

Kootenai Falls dam site, at mile 33 in sec. 13, 14, T. 31 N., R. 33 W. Topography to 110 feet.

(a) Kootenai River from point 3 miles below Troy to point 3 miles above Libby, 26 miles (12AD, 12AE). Plan and profile, 1927 and 1929. Scale, 1:48,000. Contour interval, 20 feet on land, 5 feet on water. Topography detailed. Pub lished in one sheet.

(b) Yaak River from Yaak Falls upstream 13 miles (12AF). Surveyed, 1939 and 1946. Scale, $1: 31,680$. Contour interval, 20 feet. In preparation.

(b) Yaak River from mouth to Yaak Falls, 9 miles (12AF). Shown on two sheets (one plan, one profile), 1927-34 survey of Kootenai River.

(a) Clark Fork from Deer Lodge in sec. 33, T. 8 N., R. 9 W., to St. Regis in sec. 30 , T. 18 N., R. 27 W., 189 miles (12BB, 12BC, 12BE, 12BG, 12DA). Plan and profile, 1910. Scale, 1:31,680. Contour interval, 5 feet. Very little topography. Published in Water-Supply Paper 346.

(a) Clark Fork from St. Regis in sec. 30, T. 18 N., R. 27 W., to Idaho-Montana State line, 120 miles (12DC, 12DD, 12DF, 12DG, 12DH), and 9 miles beyond to Lake Pend Oreille, Idaho. Plan and profile, 1911. Scale, 1:31,680. Contour 
interval, 25 feet on land, 5 feet on water. Topography to $25-400$ feet. Published in Water-Supply Paper 346.

(a) Clark Fork from Horse Creek in sec. 28, T. 27 N., R. 34 W., Montana, to Albany Falls, sec. 30 , T. 56 N., R. 5 W., Idaho, approximately 4 miles in Montana, 76 miles in Idaho (12DG, 12DH, 12DJ, 12DM), including dam site and Pend Oreille Lake. Plan, 1926. Scale, 1:31,680. Contour interval, 5 feet. Topography to about 100 feet. Published in five sheets, 1927.

Albany Falls dam site on Pend Oreille River (formerly Clark Fork) in

sec. $19,20,29,30$, T. 56 N., R. 5 W. Scale, 1:4,800. Contour interval, 5 feet. Topography to about 100 feet.

(b) Blackfoot River from mouth to sec. 28 , T. 14 N., R 9 W., 95 miles (12BF). Plan and profile, 1934. Scale, 1:31,680. Contour interval, 20 feet on land, 5 feet on water. Topography detailed. Published in 10 sheets ( 5 plan, 4 profile, 1 dam sites).

Box Canyon dam site, at mile 46.5 in sec. 2 , T. 14 N., R. 13 W. Scale, $1: 4,800$. Contour interval, 10 feet. Topography to 310 feet.

(c) Nevada Creek from mouth to sec. 20, T. 12 N., R. 9 W., 22 miles (12BF), and dam sites. Dam-site scale, 1:4,800; contour interral, 10 feet. Shown on three sheets (two plan, one profile), 1934 survey of Blackfoot River.

Lower Nevada Creek dam site, at mile 16.5 in sec. 9, T. 12 N., R. $10 \mathrm{~W}$. Topography to 220 feet.

Upper Nevada Creek dam sites, at mile 19.4 in sec. 13, 14, T. 12 N., R. $10 \mathrm{~W}$. Topography to 180 feet.

(c) Monture Creek from mouth to mile 6 (12BF). Shown on two sheets (one plan, one profile), 1934 survey of Blackfoot River.

(c) Cottonwood Creek from mouth to Little Cottonwood Creek, 4 miles (12BF). Shown on two sheets (one plan, one profile), 1934 survey of Blackfoot River.

(c) Clearwater River from month to sec. 25, T. 16 N., R. 15 W., 15 miles (12BF), and dam site. Shown on three sheets (two plan, one profile), 1934 survey of Blackfoot River.

Lower Clearwater River dam site, at mile 8.5 in sec. 17, T. 15 N., R. 14 W. Scale, 1:4,800. Contour interval, 10 feet. Topography to 130 feet.

(c) Belmont Creek from mouth to mile 4 (12BF). Shown on two sheets (one plan, one profile), 1934 survey of Blackfoot River.

(c) Gold Creek from mouth to mile 7 (12BF). Shown on two sheets (one plan, one profile), 1934 survey of Blackfoot River.

(c) Union Creek from mouth to mile 10 (12BF). Shown on two sheets (one plan, one profile), 1934 survey of Blackfoot River.

(c) East Twin Creek from mouth to point about 3 miles upstream (12BF). Shown on two sheets (one plan, one profile), 1934 survey of Blackfoot River.

(c) West Twin Creek from mouth to point 4 miles upstream (12BF). Shown on two sheets (one plan, one profile), 1934 survey of Blackfoot River.

(b) Flathead Lake (12CF). Plan by Rocky Mountain Power Co., approved by Federal Power Comhmission, 1932. Scale, 1:12,000. Contour interval, 2 feet and 4 feet. Topography to about 20 feet. Published in ten sheets, by Rocky Mountain Power Co., Butte, Mont., about 1932.

(b) Flathead River from Flathead Lake upstream to sec. 2, T. 28 N., R. 21 W., about 25 miles (12CE). Plan by United States Geological Survey in cooperation with Montana State, and the Rocky Mountain Power Co., 1928. Scale, 1: 12,000. Contour interval, 2 and 5 feet. Topography detailed, showing wide adjacent area to the 2,910-foot contour. Published in two sheets 40 by 54 inches and 40 by 58 inches, entitled "Topographic Map of Flathead Lake Project, Montana," by Rocky Mountain Power Co., Butte, Mont. Out of stock. 
(b) Flathead River from Flathead Lake to international boundary 113 miles, (12CA, 12CB, 12CE), and dam sites. Surveyed, 1934-38. Scale, 1:31,680. Contour interval, 20 feet on land, 5 feet on water. Topography detailed. Dam sites surveyed 1934-36; scale, 1:4,800; contour interval, 10 feet. Published in 10 sheets (eight plan, two of which show dam sites and two profile), 1947.

Bad Rock Canyon dam site. Topography to 270 feet.

Coram dam site. Topography to 120 feet.

Lower Canyon Creek dam site. Topography to 60 feet.

Canyon Creek dam site. Topography to $\mathbf{1 7 5}$ feet.

Fool Hen Hill dam site. Topography to 200 feet.

Glacier View dam site. Topography to 570 feet.

(b) Flathead River from mouth to Flathead Lake in sec. 12, T. 22 N., R. 21 W., 72 miles (12CG, 12CH), and dam sites. Plan and profile, 1934-38 and 1945-46. Scale, 1:31, 680. Contour interval, 20 feet on land and 5 feet on water. Topography detailed. Dam-site scale, 1: 9,600 except as shown. Contour interval, 10 feet on land, 1 foot on water. Published in six sheets (four plan, one profile, one dam sites), 1947.

Buffalo dam site No. 1 , at mile 68.6 , in sec. $15,21,22$, T. 22 N., R. 21 W.

Topography to 2,750-foot contour.

Buffalo dam site No. 2 , at mile 60.7 , in sec. $6,7,1,12$, T. 21 N., R. 21 , $22 \mathrm{~W}$. Topography to 2,710-foot contour.

Obow dam site, at mile 41.2, in sec. 28,29 , T. 20 N., R. 21 W. Shown on two scales, $1: 12,000$ and $1: 4,800$. Topography to 2,720 -foot contour.

Dam site No. 4, at mile 36.4, in sec. 1, T. 19 N., R. 22 W. Scale, 1:12,000.

Topography to 2,640 -foot contour.

(c) Middle Fork Flathead River from mouth to mile 49 (12CC), and dam sites. Surveyed, 1936 and 1939. Scale, 1:31,680. Contour interval, 20 feet. Dam sites surveyed, 1939. Scale, 1:4,800. Contour interval, 10 feet on land, 5 feet on water. Topography to $80-300$ feet. Published in two plan sheets, one of which shows dam sites and one profile, 1943.

Kootenai Creek dam site No. 1, in sec. 28, 29, 32, 33, T. 32 N., R. 18 W.

Kootenai Creek dam site No. 2, in sec. 29, 30, T. 32 N., R. 18 W.

(c) South Fork Flathead River from mile 44, 8 miles below junction with Spotted Bear River, to junction of Danaher and Youngs Creeks, 60 miles (12CD). Plan and profile, 1936. Scale, 1:31,680. Contour interval, 20 feet on land, 5 feet on water. Topography detailed. Published in six sheets (three plan, three profile), 1939.

(c) South Fork Flathead River from mouth to mile 44 (12CD), and Hungry Horse dam site. Surveyed, 1934-35. Scale, 1:31,680. Contour interval, 20 feet on land, 5 feet on water. Topography detailed. Published in four sheets (two plan, one profile, one showing profile and Hungry Horse dam site), 1937.

Hungry Horse dam site. Scale, 1:4,800. Contour interval, 10 feet. Topography to 420 feet. [This site is about 1 mile below site finally selected.]

(d) White River from mouth upstream 6 miles (12CD). Shown on 1936 survey of South Fork Flathead River.

(d) Big Salmon Creek and Big Salmon Lake from junction of lake outlet with South Fork Flathead River upstream 5 miles (12CD). Shown on 1936 survey of South Fork Flathead River.

(d) Little Salmon Creek from mouth upstream, 4 miles (12CD). Shown on 1936 survey of South Fork Flathead River.

(d) Gorge Creek from mouth upstream to Bunker Creek, 5 miles (12CD). Shown on 1936 survey of South Fork Flathead River. 
(d) Spotted Bear River from mouth to mile 24 (12CD). Shown on 1936 survey of South Fork Flathead River.

(c) Swan River from Flathead Lake to Lion Creek, 45 miles (12CF). Plan and profile, 1916. Scale, 1:48,000. Contour interval, 25 feet on land, 5 feet on water. Topography to 25-200 feet. Published in two sheets (one plan, one profile).

(c) Swan River from a point one mile above mouth to Swan Lake (12CF), and dam site. Plan, 1943-44. Scale, 1:31,680. Contour interval, 10 feet on land, 5 feet on water. Topography to 3,100 feet above sea level. In preparation (one plan sheet).

Dam site one mile above mouth. Scale, 1:4,800. Contour interval 10 feet. Topography to 3,100 feet above sea level.

(c) Little Bitterroot River from mouth upstream, 24 miles (12CG). Shown on 1934 38 and 1945-46 survey of Flathead River below Flathead Lake.

(c) Crow Creek from sec. 21 , T. 21 N., R. 19 W., to sec. 18, T. 21 N., R. 18 W., 5 miles (12CH). Plan and profile by United States Bureau of Reclamation, 1908. Scale, $1: 31,680$. No topography. Not published.

(c) Crow Creek from mouth upstream 2.5 miles (12CH). Shown on 1934-38 and 1945-46 survey of Flathead River below Flathead Lake.

(c) Mission Greek from sec. 16, T. 18 N., R. 19 W., to sec. 6, T. 18 N., R. 18 W., 6 miles $(12 \mathrm{CH})$. Plan and profile by United States Bureau of Reclamation, 1908. Scale, 1:31,680. No topography. Not published.

(c) Mission Creek from mouth upstream, 12 miles (12CH). Shown on 1934-38 and 1945-46 survey of Flathead River below Flathead Lake.

(d) Dry Creek from sec. 34, T. 18 N., R. 19 W., to sec. 27 , T. 18 N., R. 18 W., 8 miles (12CH). Plan and profile by United States Bureau of Reclamation, 1908. Scale, $1: 31,680$. No topography. Not published.

(d) Post Creek from sec. 4, T. 19 N., R. 19 W., to sec. 31, T. 20 N., R. 18 W., 9 miles (12CH). Plan and profile by United States Bureau of Reclamation, 1908. Scale, $1: 31,680$. No topography. Not published.

(c) Jocko River from mouth to sec. 35, T. 17 N., R. 18 W., 32 miles (12CH). Plan and profile by United States Bureau of Reclamation, 1908. Scale, 1: 126,720. No topography. Not published.

(c) Jocko River from mouth upstream io miles (12CH). Shown on 1934-38 and 1945-46 survey of Flathead River below Flathead Lake.

(c) Camas Creek from mouth upstream, 2 miles (12CH), shown on 1934-38 and 1945-46 survey of Flathead River below Flathead Lake.

For areas in Montana covered by United States Geological Survey standard topographic maps see plate 1 .

\section{NEBRASKA}

Mississippi River Basin (T).

(a) Missouri River from mouth to Three Forks, Mont., 2,551 miles. Plan based on various surveys by Corps of Engineers, United States Army, 1878-1894. Scale, 1:63,360. No contours. Topography indicated by hachures. Published in 93 sheets, including 9 index sheets, by Missouri River Commission, St. Louis, Mo.

(b) North Platte River (hcad of Platte River) from sec. 10, T. 26 N., R. 65 W., Wyoming, to sec. 20 , T. 19 N., R. 48 W., 75 miles in Nebraska, 45 miles in Wyoming (6N), covers the North Platte irrigation project. Plan by United States Burean of Reclantation, 1911. Scale, 1:31,680. Contour interval, 10 and 20 feet on land, 10 feet on water. Topography detailed.

(b) Kansas River (6R). 
(c) Republican River from a point in Kansas across the State line from Hardy, Nebraska, to Haigler, Nebraska, approximately 250 miles (6RK, 6RL, 6RM, 6RP, 6RR). Plan, 1937-39. Scale, 1:24,000. Contour interval 10 feet (5-foot contours added in dashed lines). Topography to $\mathbf{1 0 0}$ feet. Published in 15 plan sheets, $1938-41$.

For areas in Nebraska covered by United States Geological Survey standard topographic maps see plate 1 .

\section{NEVADA}

Colorado River from Black Canyon, Arizona-Nevada, upstream 68 miles, forming Arizona-Nevada State line (9LA, 9HC). Plan and profile by United States Geological Survey and United States Bureau of Reclamation, 1919-20. Scale, 1: 31,680. Contour interval, 50 feet on land, 5 feet on water. Topography to about 500 feet. Shown on 6 sheets ( 4 plan, 2 profile), 1903-19-20-23 Survey of Colorado River from Black Canyon to Lees Ferry, Ariz., (356 miles). Published in 21 sheets (14 plan, 7 profile), by United States Geological Survey, 1924.

Colorado River-Lake Mead. See Arizona (p. 5).

Colorado RIver from International boundary to Black Canyon, 352 miles (9LA, 9LB, 9LC). Plan and profile by United States Geological Survey and United States Bureau of Reclamation, 1902-03 and 1920. Scale, 1:31,680. Contour interval, 10-50 feet on land, 5 feet on water. Topography detailed. Published in 20 sheets (19 plan, 1 profile), by United States Geological Survey, 1927.

Colorado RIver dam sites partly in Nevada and partly in Arizona. For survey details see Arizona.
Hualpai Rapids.
Virgin Canyon.
Boulder Canyon.
Callville.
Upper Black Canyon.
Middle Black Canyon.
Lower Black Canyon.
Eldorado.
Eagle Rock.
Bulls Head.

(a) Virgin River from mouth upstream 37 miles $(9 K)$. Plan and profile by United States Geological Survey in cooperation with United States Bureau of Reclamation, 1903 and 1923 . Scale 1:31,680. Contour interval, 50 feet. Topography to 50-500 feet. Published in four sheets (three plan, one profile) by United States Geological Survey, 1924.

(b) Muddy River from point 3 miles below Overton in sec. 28, T. 16 S., R. 68 E., to point about 3 miles above Arrowhead Canyon, about 40 miles (9K), showing dam sites. Plan, 1934. Scale, 1:31,680. Contour interval, 20 feet on land, 5 feet on water. Topography detailed. Dam site scale, 1:6,000; contour interval, 10 feet. Published in two plan sheets, one showing also dam sites, 1937.

Narrows dam site No. 1 in sec. 7, T. 15 S., R. 67 E. Topography to 150 feet.

Narrows dam site No. 2 in sec. 16,17, T. 15 S., R. 67 E. Topography to 130 feet.

Carson River Basin (10C).

(a) Carson River from sec. 4, T. 15 N., R. 21 E., upstream to confluence of East Fork and West Fork, 27 miles $(10 \mathrm{CB}, 10 \mathrm{CA})$. Surveyed by United States Geological Survey in cooperation with United States Bureau of Reclamation, 1934-36. Scale, 1:31,680. Contour interval, 20 feet on land, 5 feet on water. Topography detailed. Complete survey includes East Fork and West Fork from mouth to points in California, and large-scale surveys of 13 dam sites Published in 10 sheets (five plan, three profile, and two showing dam sites), 1944. 
(b) East Fork Carson River from confluence with West Fork to CaliforniaNevada State line, 21 miles (10CA), showing dam sites. Dam-site scale, 1:4,800. Contour interval, 10 feet. Shown on 1934-36 survey of Carson River.

Pinyon dam site in sec. 13, 14, T. 11 N., R. 20 E. Topography to 360 feet.

Horseshoe Bend dam site, in sec. 35, T. 12 N., R. 20 E. Topography to 210 feet.

(b) West Fork Carson River from junction with East Fork to CaliforniaNevada State line, 13 miles (10CA). Shown on 1934-36 survey of Carson River. Pahranagat Lake (10KH).

(a) Pahranagat Valley from sec. 10, T. 9 S., R. 62 E., to sec. 2, T. 4 S., R. 60 E., about 35 linear miles (10KH), showing Black Canyon dam site. Surveyed, 1935-36. Scale, 1:31,680. Contour interval, 10 feet on land, 5 feet on water. Topography detailed. Published in 1 sheet, 1939.

Black Canyon dam site in Pahranagat Valley in sec. 2, T. 8 S., R. 61 E. Scale, 1:4,800. Contour interval, 10 feet. Topography to 60 feet above valley floor.

Humboldt Lake (10D).

(a) Humboldt River (10D).

(b) East Fork Humboldt River (10DA).

(c) Marys River from mouth to sec. 23, T. 44 N., R. 58 E., 70 miles (10DA), showing dam site. Plan, 1935-36. Scale, 1:31,680. Contour interval, 10 and 20 feet on land, 5 feet on water. Topography from mouth to mile 55 shows river banks and some adjacent valley floor; in the narrower valley above mile 55 topography is more detailed and shown to higher elevation above water surface. Dam-site scale 1: 4,800; contour interval 10 feet. Published in three plan sheets, showing also dam sites.

Chalk Basin dam site, at mile 65.6 in sec. 14, T. 43 N., R. 58 E. Topography to 200 feet.

Upper Marys River dam site, at mile 58.4 in sec. 5, T. 42 N., R. 59 E. Topography to 150 feet.

Lower Marys River dam site, at mile 54.9 in sec. 11, T. 42 N., R. 59 E. Topography to 130 feet.

(d) Hanks Creek from junction with Marys River to mile 5 (10DA). Shown on one sheet, $193 \overline{5}-36$ survey of Marys River.

Hanks Creek dam site, at mile 1.7. Scale, 1:4,800; contour interval, 10 feet; topography to 180 feet.

(b) North Fork Humboldt River from mouth to approximately sec. 32, T. 43 N., R. 54 E., 86 miles (10DB), showing dam sites. Surveyed, 1938-39. Scale, 1: 31,680: Contour interval, 10 and 20 feet on land, 5 feet on water. Topography detailed. Dam-site scale, 1:2,400. Published in three plan sheets, one showing dam sites, 1942.

Devils Gate dam site, in sec. 13, T. 38 N., R. 57 E. Contour interval, 10 feet. Topography to 170 feet.

Whitaker dam site, in sec. 1, T. 39 N., R. 55 E. Contour interval, 5 feet. Topography to 135 feet.

(b) South Fork Humboldt River from mouth to sec. 15, T. 31 N., R. 57 E., 37 miles (10DD), showing dam sites. Surveyed, 1935-36. Scale, 1:31,680. Contour interval, 20 feet on land, 5 feet on water. Topography detailed. Dam-site scale, 1:4,800; contour interval, 10 feet. Published in four sheets (two plan, one showing dam sites, and two profile), 1940.

Dam site No. 1, at mile 4.5 in sec. 13, 14, T. 33 N., R. 54 E. Topography to 360 feet. 
Dam site No. 2, at mile 8.5 in sec. 19 , T. 33 N., R. 55 E. Topography to 120 feet.

Dam site No. 3 and No. 4 in sec. 6, T. 32 N., R. 55 E. Topography to 150 feet.

(c) Smith Creek from junction with South Fork Humboldt River upstream 11 miles (10DD), showing dam site. Shown on one sheet, 1985-36 survey of South Fork Humboldt River.

Twin Bridges dam site, at mile 0.8 in sec. 36, T. 32 N., R. 55 E. Scale, $1: 4,800$. Contour interval, 10 feet. Topography to 110 feet.

(b) Little Humboldt River from sec. 35, T. 40 N., R. 39 E., to forks in sec. 25, T. 41 N., R. 42 E., 27.5 miles (10DJ), showing dam sites. Plan 1934-35. Scale, $1: 31,680$. Contour interval, 20 feet on land, 5 feet on water. Topography detailed. Dam-site scale, 1:4,800; contour interval, 10 feet. Published in four sheets, showing also dam sites, 1938.

Hot Spring dam site, at mile 15.4 in sec. 20, T. 41 N., R. 41 E. Topography to 170 feet.

Chimney dảm site, at mile 27 , in sec. 36, T. 41 N., R. 42 E. Topography to 90 feet.

(c) North Fork Little Humboldt River from mouth to sec. 7, T. 44 N., R. 42 E., 31 miles (10DJ), and dam site. Plan shown on two sheets, 1934-35 survey of Little Humboldt River.

Greeley Flat dam site, at mile 53.9 in sec. 23 , T. 44 N., R. 42 E. Scale 1:4,800. Contour interval, 10 feet. Topography to 150 feet.

(c) South Fork Little Humboldt River from mouth to sec. 6, T. 41 N., R. 45 E., 15 miles (10DJ), and dam site. Plan shown on two sheets, 1934-35 survey of Little Humboldt River.

Latons Spring dam site, at mile 8.8 in sec. 1, T. 41 N., R. 43 E. Scale, 1: 4,800. Contour interval, 10 feet. Topography to 140 feet.

(d) Milligan Creek from mouth to sec. 8, T. 42 N., R. 45 E., 7 miles (10DJ). Plan shown on 1 sheet, 1934-35 survey of Little Humboldt River.

(c)' Martins Creek from sec. 35, T. 40 N., R. 39 E., to mile 27, sec. 9, T. 43 N., R. 41 E. (10DJ). Dan-site scale, 1:4,800; contour interval, 10 feet. Plan shown on 2 sheets, 1934-35 survey of Little Humboldt River.

Sugarloaf dam site, at mile 18.9 in sec. 1, 12, T. 42 N., R. 40 E. Topography to 240 feet.

Hardscrabble dam site, at mile 24.5 in sec. 21, T. 43 N., R. 41 E. Topography to 120 feet.

(c) Cottonwood Creek from sec. 3, T. 39 N., R. 39 E., to mile 17, sec. 23 , T. 42 N., R. 39 E. (10DJ). Plan shown on two sheets, 1934-35 survey of Little Humboldt River.

(d) Indian Creek from mouth to sec. 19, T. 42 N., R. 40 E., 6 milesi (10DJ). Plan shown on one sheet, 1934-35 survey of Little Humboldt River.

REese River Basin (10DG).

(a) Reese River from sec. 24 , T. 21 N., R. 42 E., to sec. 33 , T. 12 N., R. 40 E., 74 miles (10DG). Plan, 1935. Scale, 1:31,680. Contour interval, 20 feet on land, 5 feet on water. Shows river, highway, and immediately adjacent topography. Published in three sheets, 1937.

Black Rock Desert Basin (10AG).

(a) Quinn River from Oregon-Nevada State line to sec. 10, T. 45 N., R. 37 E., 20 miles (10AH). Surveyed, 1939. Scale, 1:31,680. Contour interval, 10 feet on land, 5 feet on water. Topography detailed. Published in 1 sheet, 1940.

For areas in Nevada covered by United States Geological Survey standard topographic maps see plate 1 . 


\section{NEW HAMPSHIRE}

Androscogarn River. See Maine (p. 54).

Pemigewasset River (head of Merrimack River) (1EA).

(a) Mad River from Snow Brook to head, 5 miles (1EA). Plan, 1912. Scale, $1: 24,000$. Topography detailed. One sheet. Out of stock.

Pemigewasset River Basin. Headwaters of the following brooks have been surveyed from to 2 to 4 miles: Anderson, Gibbs, Burnt, Covert, and Shoal Pond. Scale, $1: 9,600$ to $1: 24,000$. Contour interval, 20 and 100 feet. Each brook shown on single sheet. Out of stock.

ConNeCTICUT River (1G).

(a) Ammonoosuc River from Assaquan Brook to headwaters, 5 miles (1GB). Plan, 1912. Scale, 1:24,000. Contour interval, 100 feet. Topography detailed. One sheet. Out of stock.

(b) Zealand River from Zealand Pond downsteam 5 miles (1GB). Plan, 1911-12. Scale, 1:24,000. Contour interval, 100 feet. Topography detailed. One sheet. Out of stock.

For areas in New Hampshire covered by United States Geological Survey standard topographic maps see plate 1 .

\section{NEW JERSEY}

For areas in New Jersey covered by United States Geological Survey standard topographic maps see plate 1 .

\section{NEW MEXICO}

MISSISSIPPI RIVER BASIN (7).

(a) ARKansas RiVer (7F).

(b) Canadian River (7C).

(c) Chicorica Creek from mouth to point 500 feet downstream from Lake Maloya Dam, about 22 miles (7CA). Plan by United States Geological Survey for United States Bureau of Reclamation, 1945. Scale, 1:24,000. Contour interval, 10 and 20 feet with 5 -foot contours added in places. Topography detailed, including survey of abandoned Hebron Reservoir. Unpublished map in files of United States Bureau of Reclamation.

(c) Mora River from mouth to sec. 5, T. 18 N., R. 21 E., 36 miles (7CD). Plan and profile, 1915. Scale, 1:31,680. Contour interval 25 feet on land, 5 feet on water. Topography to $100-500$ feet. Published in Water-Supply Paper 421.

Rio Grande from Embudo in sec. 19, T. 23 N., R. 10 E., to Colorado-New Mexico State line, 68 miles (8BG, 8BF). Plan and profile, 1915. Scale, 1:31,680. Contour interval, 25 feet on land, 5 feet on water. Topography to $200-500$ feet. Published in Water-Supply Paper 421.

Rio Gránde from Otowi to Embudo Creek in sec. 19, T. 23 N., R. 10 E., 34 miles (8BL, 8BG). Plan and profile, 1933-35. Scale, 1:31,680. Contour interval, 20 feet on land, 5 feet on water. Topography detailed. Publised in two sheets (one plan, one profile), 1938.

RIo GraNDE from Cochiti Diversion Dam to Otowi, 24 miles, with dam sites $(8 B L)$. Control by United States Breau of Reclamation, topography by United States Geological Survey, 1937, 1941. Scale, 1:12,000. Contour interval, 10 feet on land, 5 feet on water. Topography to 300 feet. Dam-site scale, 1:4,800; contour interval 5 feet except as noted. Published in four sheets (two plan, which also show dam sites, one showing dam sites, one profile).

Buckman Dam Site No. 1, mile 23.6. Topography to 225 feet. Plan on sheet 4 , profile on sheet 6 . 
Buckman Dam Site No. 2, mile 22.1. Topography to 200 feet. Plan on sheet 4 , profile on sheet 6 .

Buckman Dam Site No. 3, mile 19.1. Topography to 200 feet. Plan on sheet 3 , profile on sheet 6 .

Rio Chiquito Dam Site No. 1, mile 4.4. Contour interval, 10 feet on land and 5 feet on water. Topography to 330 feet. Plan on sheet 5 , profile on sheet 6 .

Rio Chiquito Dam Site No. 2, mile 3.4. Contour interval, 10 feet on land, 5 feet on water. Topography to 300 feet. Plan on sheet 5 , profile on sheet 6 .

Rio Grande from sec. 4, T. 16 N., R. 6 E., to sec. 13, T. 19 N., R. 7 E., 23 miles (8BL). Plan and profile, 1915. Scale, 1:31,680. Contour interval, 25 feet on land, 5 feet on water. Topography 100-200 feet. Published in Water-Supply Paper 421.

Rio Grande from San Marcial to mouth of White Rock Canyon, in sec. 9, T. 16 N., R. 6 E., about 180 miles ( $8 B L, 8 B M, 8 C A, 8 C C)$. Plan by the State in 1917-18. Scale, 1 inch $=2,000$ feet. Contour interval, 2 and 10 feet. Topography to 50-100 feet. Published by State in 17 sheets.

Rio Grande from Mescal Canyon to San Marcial, 57 miles (8CC, 8CE). Showing Elephant Butte reservoir site of Rio Grande project. Plan by United States Bureau of Reclamation, 1903 and 1909. Scale 1:60,000. Contour interval, 50 feet. Topogranhy to 50 feet. Not published.

Rio Grande from sec. 19, T. 16 S., R. 4 W., to sec. 32 , T. 10 S., R. 3 W., about 50 miles $(8 \mathrm{CC}, 8 \mathrm{CE})$. Plan by United States Bureau of Reclamation, 1903. Scale, 1:12,000. Contour interval, 10 feet. Topography to about 70 feet. Not published.

Rio Grande from sec. 12, T. 35 S., R. 9 E., in Texas, to sec. 9, T. 21 S., R. 1 W., in New Mexico, about 150 miles (8CF, 8CE). Plan by United States Bureau of Reclamation, 1908-4. Scale, 1:12,000. Contour interval, 10 feet on land, 5 feet on water. Topography to 10-50 feet. 16 sheets. Not published.

(a) Rio Chama from junction with Rio Grande to point 17 miles above junction with Willow Creek, 103 miles (8BJ, 8BH), and dam sites. Plan and profile, 1933-37. Scale, 1:31,680. Contour interval 20 feet on land, 5 to 20 feet on water. Topography, detailed. Dam site scale, 1:4,800; contour interval, 10 feet. Published in eight sheets ( $s i x$ plan, four of which show dam sites, two profile), in 1939.

Canyon de Chama dam site, mile 45.9 , T. 24 N., R. 3 E., on Canyon de Chama Grant. Topography to 200 feet.

Abiquiu dam site, at mile 31.8 in sec. 8 , T. 23, N., R. 5 E. Topography to 310 feet.

(b) Willow Creek from junction with Rio Chama to mile 16 (8BH), and dam sites, all within Tierra Amarilla Grant. Dam site scale, 1:4,800; contour interval, 10 feet. Shown on two sheets (one plan, one profile), 1933-37 survey of Rio Chama.

Lower Willow Creek dam site, at mile 0.4. Topography to 300 feet.

Upper Willow Creek dam site, at mile 8.9. Topography to 150 feet.

Middle dam sites $\mathbf{A}$ and $\mathbf{B}$, at mile 5.0 and mile 5.9, respectively. Topography to 150 feet.

(b) Rio Puerco from junction with Rio Chama to mile 4 (8BJ). Shown on one sheet, 1933-37 survey of Rio Chama.

(a) Pecos River from sec. 16, T. 16 N., R. 12 E., to Panchuela Creek, 17 miles (8FA). Plan and profile, 1915. Scale, 1:31,680. Contour interval, 25 feet on land, 5 feet on water. Topography to 200-300 feet. Published in Water-Supply Paper 421, 
(a) Pecos River from sec. 2, T. 23 S., R. 28 E.. to sec. 24, T. 22 S., R. 27 E., 9 miles $(8 \mathrm{FL})$. Plan and profile by United States Bureau of Reclamation. Scale, 1:12,000. Contour interval, 5 feet. Topography on west bank only. Not published.

(a) Pecos River from sec. 32, T. 24 S., R. 29 E., to point near Malaga, about 470 miles ( $8 \mathrm{FL}, 8 \mathrm{FH}, 8 \mathrm{FF}, 8 \mathrm{FE}, 8 \mathrm{FC}, 8 \mathrm{FA}$ ), and dam sites. About 60 miles, from Dayton to point near Malaga, reproduced from early surveys by United States Bureau of Reclamation. About 410 miles surveyed by United States Geological Survey, 1934-37. Scale, 1:31,680. Contour interval, 10 and 20 feet on land, 5 feet on water. Wide area of adjacent topography shown for most of section. Dam-site scale, $1: 4,800$; contour interval, 10 feet. In preparation.

Los Esteros dam site, about 7 miles north of Santa Rosa. Topography to 180 feet.

Los Ojitos dam site, near Los Ojitos. Topography to 200 feet.

Tecolotito dam site, about 16 miles below Villanueva. Topography to 200 feet.

(b) Gallinas River from mouth to mile 57, approximately 6 miles below Las Vegas, N. Mex. (8FB). Plan and profile, 1938-39. Scale, 1:31,680. Contour interval, 10 and 20 feet on land, 5 feet on water. Topography to 150 feet. Published in four sheets (two plan, two profile).

(b) Rio Penasco from junction with Pecos River to sec. 19, T. 17 S., R. 21 E., 45 miles (8FK). Plan and profile, 1935-36. Scale, 1:31,680. Contour interval, 10 feet on land, 5 feet on water. Topography detailed. Published in three sheets (two plan, one profile), 1939.

(a) Gila River from Arizona-New Mexico State line upstream to sec. 20, T. 19 S., R. 20 W., and from sec. 4, T. 16 S., R. 17 W., to point 6 miles above confluence of East Fork and West Fork, about 60 miles (9MA) and dam sites. Surveyed, 1934-35. Scale, 1:31,680. Contour interval, 20 feet on land, 5 feet on water. Dam-site scale $1: 4,800$. Contour interval 10 feet. Topography detailed. In preparation. See also Arizona.

Two Forks dam site, just below confluence of East Fork and. West Fork. Topography to 280 feet. In preparation.

Alum Canyon dam site, about 4 miles below confluence of East Fork and West Fork. Topography to $\mathbf{3 5 0}$ feet. In preparation.

(a) Gila River from sec. 19, T. 19 S., R. 19 W., to sec. 29 , T. 18 S., R. 18 W., 10 miles (9MA), Red Rock Reservoir site. Plan, 1920. Scale, $1: 24,000$. Contour interval, 10 feet. Topography to 150 feet at dam site. Published on one sheet, showing also Alma reservoir site on San Francisco River, in 1928.

(a) Gila River from sec. 20, T. 19 S., R. 20 W., to sec. 4, T. 16 S., R. 17 W., 44 miles (9MA). Plan and profile, 1915. Scale, 1:31,680 Contour interval, 25 feet on land, 5 feet on water. Topography to 100-500 feet above water surface. Dam-site scale, 1 : 12,000; contour interval, 25 feet ; topography to 200 feet. Published in Water-Supply Paper 396.

Dam site in sec. 19, T. 19 S., R. 19 W.

Dam site in sec. 32, 33, T. 17 S., R. 17 W.

Cliff dam site in NE1/4 sec. 21, T. 16 S., R. 17 W. Scale, 1:2,40,0.

Contour interval, 10 feet. Topography to 220 feet. Not published.

Three potential dam sites also surveyed in connection with Red Rock reservoir site. Scale, 1:1,200. Contour interval, 10 feet. Not published.

(b) East Fork Gila River from confluence with West Fork upstream 3 miles (9MA). Shown on 1934-35 survey of Gila River.

(b) West Fork Gila River from confluence with East Fork upstream 10 miles (9MA). Shown on 1934-35 survey of Gila River. 
T. J. dam site, 2 miles above junction of Gila River and East.Fork. Scale, 1:4,800. Contour interval, 10 feet. Topography to 220 feet.

(b) San Francisco River from sec. 9, T. 11 S., R. 20 W., to sec. 4, T. 10 S., R. $20 \mathrm{~W}$., 10 miles (9MB), Alma reserroir site. Plan, 1920. Scale, 1:24,000. Contour' interval, 10 feet. Topography to 200 feet at dam site. Published on one sheet, showing also Red Rock reservoir site on Gila River, 1928.

(b) San Francisco River, New Mexico and Arizona, from mouth in Arizona to sec. 8, T. 11 S., R. 20 W., 77 miles, of which 31 miles are in New Mexico (9MB), showing Pleasanton dam site. Plan and profile, 1934-35. Scale, 1:31,680. Contour interval, 20 feet on land, 5 feet on water. Published in four sheets (two plan, one showing also dam site, and two profile), 1939.

Pleasanton dam site, at mile 63.3 in sec. 26 , T. 12 S., R. 20 W., New

Mexico. Scale, 1:2,400. Contour interval, 10 feet. Topography to 400 feet.

(a) San Juan River from sec. 1, T. 29 N., R. 17 W., to sec. 18, T. 29 N., R. 9 W., 52 miles (9GA, 9GC). Surveyed, 1936-37. Scale, 1:31,680. Contour interval, 10 and 20 feet on land, 5 feet on water. Wide area of adjacent topography: In preparation.

(a) San Juan River from sec. 33, T. 32 N, R. 6 W., to Colorado State line, 6.1 miles (9GA), Arboles Reservoir site. Plan by. United States Bureau of Reclamation, 1933. Scale, 1:12,000. Contour interval, 20 feet on land and water, 10 feet in a few wide valleys. Topography detailed. In preparation.

(a) San Juan River from sec. 18, T. 29 N., R. 9 W., to sec. 33, T. 32 N., R. 6 W., 38.9 miles (9GA). Plan, 1938-39. Scale, 1:31,680. Contour interval, 20 feet on land, 5 feet on water. Topography detailed. In preparation.

(b) Pine River from mouth to sec. 6, T. 31 N., R. 7 W., 10.3 miles (9GA). Shown on 1938-39 survey of San Juan River. In preparation.

For areas in New Mexico covered by United States Geological Survey standard topographic maps see plate 1 .

\section{NEW YORK}

Hudson Rrver from month to source, 159 miles (1KA, 1KB, 1KE, 1KF, 1JA, 1JB, 1JC, 1JD, 1JK, 1JL). Profile, 1908. Scale, 1 inch $=2$ miles. Published in Fourth Annual Report, New York State Water Supply Commission, 1909.

(a) Fishing Brook from mouth to source, 18 miles (1JA). Profile, 1908. Scale, 1 inch $=2$ miles. Published in Fourth Annual Report, New York State Water Supply Commission, 1909.

(a) Cedar River from mouth to source, 36 miles (1JA). Profile, 1908. Scale, 1 inch $=2$ miles. Published in Fourth Annual Report, New York State Water Supply Commission, 1909 .

(b) Rock River from mouth to source, 13 miles (1JA). Profile, 1908. Scale, 1 inch $=2$ miles. Published in Fourth Annual Report, New York State Water Supply Commission, 1909.

(a) Indian River from mouth, to mouth of Jessup River, 21 miles (1JA). Profile, 1908. Scale, 1 inch $=2$ miles. Published in Fourth Annual Report, New York State Water Supply Commission, 1909.

(a) Jessup River from mouth to source, 15 miles (1JA). Profile, 1908. Scale, 1 inch $=2$ miles. Published in Fourth Annual Report, New York State Water Supply Commission, 1909.

(a) Boreas River from mouth to source, 23 miles (1JB). Profile, 1908. Scale, 1 inch $=2$ miles. Published in Fourth Annual Report, New York State Water Supply Commission, 1909. 
(a) Whirteenth Brook from mouth to source, 8 miles (1JB). Profile, 1908. Scale, 1 inch $=2$ miles. Published in Fourth Annual Report, New York State Water Supply Commission, 1909.

(a) Schroon River from mouth to source, 61 miles (1JB). Profile, 1908. Scale, 1 inch $=2$ miles. Published in Fourth Annual Report, New York State Water Supply Commission, 1909.

(a) Schroon River from Tumblehead Falls to Schroon Falls, 24 miles (1JB). Plan, 1909. Scale, 1:38,000. Contour interval, 20 feet. Topography to 20-60 feet. Published in Fourth Annual Report, New York State Water Supply Commission, 1909.

(b) Black Brook near (East) North Hudson (1JB), Hammond Pund reservoir site. Plan, 1902. Scale, 1:9,600. Contour interval, 10 feet. Topography to 50 feet at dam site. Published by New York State Water Storage Commission, 1903.

Hammond Pond dam site. Scale, 1: 1,200. Contour interval, 2 feet. Topography to 40 feet.

(b) Branch of Schroon River from mouth to source, 16 miles (1JB). Profile, 1908. Scale 1 inch $=2$ miles. Published in Fourth Annual Report, New York State Water Supply Commission, 1909.

(b) Paradox Creek from mouth to source, 15 miles (1JB). Profile, 1908. Scale, 1 inch $=2$ miles. Published in Fourth Annual Report, New iork State Water Supply Commission, 1909.

(b) Mill Brook from mouth to source, 13 miles (1JB). Profile, 1908. Scale, $\mathbf{1}$ inch $=2$ miles. Published in Fourth Annual Report. New York State Water Supply Commission, 1909.

(b) Trout Brook from mouth to source, 19 miles (1JB). Profile, 1908. Scale, 1 inch $=2$ miles. Published in Fourth Annual Report, New York State Water Supply Commission, 1909.

(c) Minerva Stream from mouth to source, 15 miles (1JB). Profile, 1908. Scale, 1 inch $=2$ miles. Published in Fourth Annual Report, New York State Water Supply Commission, 1909.

(a) Sacandaga River from mouth to source, 75 miles (IJC). Profile, 1908. Scale, 1 inch $=2$ miles. Published in Fourth Annual Report, New York State Water Commission, 1909.

(b) Sacandaga Lake and Pleasant Lake (1JC). Plan, 1908. Scale 1:20,000. Contour interval, 10 feet. Very little topography; flow line of proposed reservoir shown. Published in Fourth Annual Report, New York State Water Supply Commission, 1909.

(a) Sacandaga reservoir, from Hadley to Broadalbin (1JC). Plan, 1907. Scale, (original) 1:4,800. Contour interval, 5 feet. Published in 33 sheets (11 showing towns within flowage area, and dam sites, 22 showing reservoir site, in Third Annual Report, New York State Water Supply Commission, 1908.

Dam site near Conklingville. Scale, 1: 4,500. Contour interval, 5 feet. Topography to 100 feet.

(b) Kunjamuk Creek from mouth to source, 15 miles (1JC). Profile, 1908. Scale, 1 inch $=2$ miles. Published in Fourth Annual Report, New York State Water Supply Commission, 1909.

(b) East Branch Sacandaga River from mouth to source, 25 miles (1JC). Profile, 1908. Scale, 1 inch $=2$ miles. Published in Fourth Annual report, New York State Water Supply Commission, 1909.

(b) West Branch Sacandaga River from mouth to source, 31 miles (1JC). Profile, 1908. Scale, 1 inch $=2$ miles. Published in Fourth Annual Report, New York State Water Supply Commossion, 1909.

(b) West Branch Sacandaga River near Piseco Lake (1JC), Piseco Lake reservoir site. Plan, 1902. Scale, 1:19,200. Contour interval, 10 feet. Topog- 
raphy to 80 feet at dam site. Published by New York State Water Storage Commission, 1903.

Dam site. Scale, 1:4,800. Contour interval, 10 feet. Topography to 80 feet.

(b) Vly Creek from mouth to junction of Mayfield Creek and Kenyetto Creek, 5 miles (1JC). Profile, 1908. Scale, 1 inch $=2$ miles. Published in Fourth Annual Report, New York State Water Supply Commission, 1909.

(c) Mayfield Creek from mouth to source, 11 miles (1JC). Profile, 1908. Scale, 1 inch $=2$ miles. Published in Fourth Annual Report, New York State Water Supply Commission, 1909.

(c) Kenyetto Creek from mouth to junction of Alder Creek and Cadman Creek, 16 miles (1JC). Profile, 1908. Scale, 1 inch $=2$ miles. Published in Fourth Annual Report, New York State Water Supply Commission, 1909.

(c) Hans Creek from mouth to source, 17 miles (1JC). Profile, 1908. Scale 1 inch $=2$ miles. Published in Fourth Annual Report, New York State Water Supply Commission, 1909.

(a) Batten Kill from mouth to source, 56 miles (1JD). Profile, 1908. Scale, 1 inch $=2$ miles. Published in Fourth Annual Report, New York State Water Supply Commission, 1909.

(a) Fish Creek from month to source, 43 miles (1JD). Profile, 1908. Scale, 1 inch $=2$ miles. Published in Fourth Annual Report, New York State Water Supply Commission, 1909.

(a) Hoosic River from mouth to point 5 miles above Cheshire, 66 miles (1JE). Profile, 1908. Scale, 1 inch $=2$ miles. Published in Fourth Annual Report, New York State Water Supply Commission, 1909.

DeLaware RIVer from New York-Pennsylvania State line to confluence of East Branch and West Branch, 76 miles (1LC, 1LE). Profile, 1908. Scale, 1 inch=2 miles. Published in Fourth Annual Report, New York State Water Supply Commission, 1909.

Delaware River from Narrowsburg to Cochecton, 10 miles (1LC), Cochecton reservoir site. Plan, 1908. Scale, 1:13,200. Contour interval, 10 feet. Topography to 30-60 feet. Dam-site scale, $1: 1,320$; contour interval, 5 feet; topography to 70 feet. Published in Fourth Annual Report, New York State Water Supply Commission, 1909.

(a) West Branch Delaware River from point 5 miles below Cannonsville Bridge to Granton, 10 miles (1LA), Cannonsville reservoir site. Plan, 1908. Scale, 1:13,209. Contour interval, 10 feet. Dam-site scale, 1:1,200; contour interval, 5 feet; topography to 80 feet. Published in Fourth Annual Report, New York State Water Supply Commission, 1909.

(a) West Branch Delaware River from junction with East Branch to point 41:2 miles above Granton Bridge, 31 miles (1LA). Profile, 1908. Scale, 1 inch $=2$ miles. Published in Fourth Annual Report, New York State Water Supply Commission, 1909.

Susquehanna RIVer in Binghamton, 6 miles (1NC, 1NF). Plan based on survey in 1890. Scale, $1: 9,250$. No contours. Published by New York Water Storage Commission, 1903.

(a) Chemung River at Elmira, 2 miles (1NJ). Plan from survey in 1889 and profile. Scale, 1:2,400. No contours. Many elevations. Published by New York State Water Storage Commission, 1903.

(b) Canisteo River through Hornellsville, 6 miles (1NH). Plan, 1902. Scale, $1: 5,250$. Contour interval, 2 feet. Topography shown only in area flooded at high water. Published by New York State Water Storage Commission, 1903. 
(b) Canisteo River through Canisteo, 6 miles (1NH). Plan, 1902. Scale, 1:5,250. Contour interval, 2 feet. Topography shown only in area flooded at high water. Published by New York State Water Storage Commission, 1903.

(a) Chenango River in Binghamton, $2 \frac{1}{2}$ miles (1NE). Plan from surveys in 1890. Scale, 1:9,250. No contours. Published by New York State Water Storage Commission, 1908.

Niagara River from Lake Erie to Lake Ontario, 37 miles (4MA). Profile. Scale, 1 inch $=1.4$ miles. Published in Second Annual Report, New York State Conservation Commission, Division of Inland Waters, 1912.

Niagara River from La Salle to Lewiston, 15 miles (4MA). Plan by Corps of Engineers, United States Army, 1919. Scale, 1:10,000. Contour interval, 2 and 10 feet on land; no water-surface contours. Topography detailed. Published in report entitled Diversion of Water From the Great Lakes and Niagara River, Government Printing Office, 1921.

ST. LAWRHNCE RIVER from Ogdensburg to Montreal, 120 miles (4). Plan and profile. Scale, 1 inch $=5$ miles. No contours. Published in Second Annual Report, New York State Water Power Commission, 1922.

(a) Buffalo River in Buffalo, from mouth upstream, 8 miles (4LJ). Plan and profile by Bureau of Engineering of Buffalo, 1902. Scale, 1:7,200. No contours. Shows area affected by floods. Published by New York State Water Storage Commission, 1903.

(a) Little Tonawanda Creek from Linden to Dale, 6 miles (4MA). Linden reservoir site. Plan, 1912. Scale, 1:12,000. Contour interval, 5 feet. Topography to 30-70 feet. Published in Second Annual Report, New York State Conservation Commission, 1912.

(a) Genesee River in Rochester, 9 miles (4MF). Plan from surveys prior to 1902. Scale, 1:17,300. No contours. Published by New York Water Storage Commission, 1903.

(a) Genesee River from power house site below Portage upstream 28 miles (4ME). Portage reservoir site. Plan, 1907. Scale, 1:22,600. Contour interval, 10 and 20 feet. Topography detailed. Published in Third Annual Report, New York State Water Supply Commission, 1908.

Dam site. Scale, 1:4,450. Contour interval, 10 feet. Topography to 150 feet.

(a) Black River from point below Hawkinsville to Forestport, 8 miles (4NH), Hawksville reservoir site. Plan. Scale, 1:30,000. Contour interval, 20 feet. Topography to 20-120 feet. Published in Sixth Annual Report, New York State Water Supply Commission, 1911.

Dam site. Scale, 1:10,800. Contour interval, 10 feet. Topography to 100 feet.

(b) Moose River (4NH).

(c) South Branch Moose River from Higley Mountain upstream 13 miles (4NH). Higley Mountain reservoir site. Plan. Scale, 1:43,200. Contour interval, 20 and 100 feet. Topography to $200-400$ feet. Published in Sixth Annual Report, New York State Water Supply Commission, 1911.

(a) Oswegatchie River from mouth to junction of East Branch and West Branch, 73 miles (4OC). Profile. Scale, 1 inch $=4$ miles. Published in Third Annual Report, New York State Conservation Commission, Division of Inland Waters, 1913.

(a) East Branch Oswegatchie River (head of Oswegatchie River) from Newton Falls to Cranberry Lake, 11 miles (4OB), Newton Falls reservoir site. Plan 1913. Scale, $1: 36,000$. Contour interval, 10 feet. Topography to 40 feet at dam site. Published in Third Annual Report, New York State Conservation Commission, Division of Inland Waters, 1913. 
(a) East Branch Oswegatchie River (head of Oswegatchie River) from mouth to Cranberry Lake, 42 miles ( $4 \mathrm{OB}$ ). Profile. Scale, 1 inch $=4$ miles. Published in Third Annual Report, New York State Conservation Commission, Division of Inland Waters, 1913.

(b) West Branch Oswegatchie River from mouth to point 7 miles above Harrisville, 27 miles (4OB). Profile. Scale, 1 inch $=4$ miles. Published in Third Annual Report, New York State Conservation Commission, Division of Inland Waters, 1913.

(b) West Branch and Middle Branch Oswegatchie River from their confluence to 4 miles on West Branch and about 7 miles on Middle Branch (4OB), Harrisville reservoir site. Plan. Scale, 1:36,000. Contour interval, 10 feet. Topography to 40 feet. Published in Third Annual Report, New York State Conservation Commission, Division of Inland Waters, 1913.

(b) Indian River (tributary to Oswegatchie River) from Black Lake to Indian Lake, 70 miles (4OC). Profile. Scale, 1 inch $=4$ miles. Published in Third Annual Report, New York State Conservation Commission, Division of Inland Waters, 1913.

(a) Raquette River from mouth to source, 165 miles (4OF). Profile, 1908. Scale, 1 inch $=3.6$ miles. Published in Fourth Annual Report, New York State Water Supply Commission, 1909.

(a) Raquette River from Colton downstream 11/4 miles (4OF). Plan, 1908. Scale, 1:1,800. Contour interval, 5 feet. Topography to 15-175 feet. Published in Fourth Annual Report, New York State Water Supply Commission, 1909.

(a) Raquette River from Raquette Pond to Raquette Falls, 19 miles (4OF), Tupper Lake reservoir. Plan, 1909. Scale, 1:34,000. Contour interval, 20 feet. Topography to 50 feet. Published in Fourth Annual Report, New York State Water Supply Commission, 1909.

(b) Brandreth Lake Branch from outlet of Forked Lake to source, 13 miles (4OF). Profile, 1908. Scale, 1 inch $=3.6$ miles. Published in Fourth Annual Report, New York State Water Supply Commission, 1909.

(b) Sucker Brook from Raquette Lake to source, 10 miles (4OF'). Profile, 1908. Scale, 1 inch $=3.6$ miles. Published in Fourth Annual Report, New York State Water Supply Commission, 1909.

(b) Cold River from mouth to source, 20 miles (4OF). Profile, 1908. Scale, 1 inch $=3.6$ miles. Published in Fourth Annual Report, New York State Water Supply Commission, 1909.

(b) Bog River from Tupper Lake upstream 10 miles (4OF). Profile, 1908. Scale, 1 inch $=3.6$ miles. Published in Fourth Annual Report, New York State Water Supply Commission, 1909.

(c) Little Tupper Lake Branch from mouth to source, 19 miles (4OF). Profile, 1908. Scale, 1 inch $=3.6$ miles. Published in Fourth Annual Report, New York State Water Supply Commission, 1909.

For New York areas covered by United States Geological Survey standard topographic maps see plate 1.

\section{NORTH CAROLINA}

Roanoke Rrver from Weldon, N. C., to Roanoke, Va., 32 miles in North Carolina, 202 miles in Virginia (2CA, 2CB, 2CF). Plan and profile, 1905. Scale, 1: 24,000. No topography. Published in 11 sheets, plan and profile on each; 1 sheet showing section of river in North Carolina, 10 showing section in Virginia. Out of stock.

CaPe Fear River from Fayetteville to Natmore Creek, 77 miles (2EF, 2EG). Plan by Corps of Engineers, United States Army. Scale, 1:12,000. Contour interval, 10 feet. Topography to 70 feet. Eight sheets. Not published. 
(a) Deep River from mouth to Jamestown, $11 t$ miles $(2 \mathrm{EC}, 2 \mathrm{FD})$. Scale, 1:51,000. No contours. Published in report Water-power Investigation of Deep River in Economic Paper 54, by North Carolina Geological and Economic Survey.

YADKIN Rrver from Tinsley Shoals, 12 miles above North Wilkesboro, to Barlow Shoals, 3 miles (2FB). Profile. Scale, 1 inch $=800$ feet. Published in report Water-power Survey of Surry and Wilkes Counties, in Economic Paper 53, by North Carolina Geological and Economic Survey, 1922.

YADKIN RIVER, 12 miles above North Wilkesboro (2FB), Tinsley Shoals dam site. Plan. Scale, 1:5,450. Contour interval, 10 feet. Topography to 60 feet. Published in report Water-power Survey of Surry and Wilkes Counties, in Economic Paper 53, by North Carolina Geological and Economic Survey, 1922.

YAJKIN RIVER from Bean Shoals, $71 / 2$ miles below mouth of Ararat River to North Wilkesboro, 57 miles $(2 \mathrm{FB}, 2 \mathrm{FC})$. Profile. Scale, 1 inch $=1 / 2$ mile. Published in report Water-power Survey of Surry and Wilkes Counties, in Economic Paper 53, by North Carolina Geological and Economic Survey, 1922.

YADKIN RIVER at Bean Shoals, from mouth of Little Yadkin River upstream 4 miles (2FC). Plan and prcfile. Scale, 1:14,600. Two contours. Also map of river for $21 / 2$ miles above dam site at Bean Shoals; scale 1:6,320, contour interval, 10 feet; topography to $\mathbf{7 0}$ feet. Published in report Water-power Survey of Surry and Wilkes Counties in Economic Paper 53, by North Carolina Geological and Economic Survey, 1922.

YADKIN RIVER from Uwharrie River to Abbots Creek, 19 miles (2FD). Plan by United States Geological Survey in cooperation with North Carolina Geological Survey, 1898. Scale, 1:32,000. Contour interval, 10 feet. Topography to 20-50 feet. Published in report Water-power, North Carolina Geological Survey Bulletin 8, 1899.

(a) Lewis Fork in Wilkes County, from mouth upstream 4 miles (2FB). Profile. Scale, 1 inch $=1,600$ feet. Published in report entitled "Water-power Survey of Surry and Wilkes Counties," in Economic Paper 53, by North Carolina Geological and Economic Survey, 1922.

(b) South Fork Lewis Fork in Wilkes County, from mouth upstream 5 miles (2FB). Profile. Scale, 1 inch $=1,600$ feet. Published in report entitled Waterpower survey of Surry and Wilkes Counties. in Economic Paper 53, by North Carolina Geological and Economic Survey, 1922.

(b) West Fork Lewis Fork in Wilkes County, from mouth upstream 4 miles (2FB). Profile. Scale, 1:1,765. Published in report entitled "Water-power Survey of Surry and Wilkes Counties," in Economic Paper 53, by North Carolina Geological and Economic Survey, 1922.

(a) Roaring River from mouth upstream 11 miles (2FB). Profile. Scale, 1 inch $=4,000$ feet. Published in report entitled "Water-power Survey of Surry and Wilkes Counties," in Economic Paper 53, by North Carolina Geological and Economic Survey, 1922.

(a) Elkin River from mouth to Elkin Power Company's dam, 4 miles (2FB). Profile. Scale, 1 inch=1,650 feet. Published in report entitled "Water-power Survey of Surry and Wilkes Counties," in Economic Paper 53, by North Carolina Geological and Economic Survey, 1922.

(a) Mitchell River from point 1 mile below Cumming's Mill and 3 miles above mouth upstream 18 miles (2FB). Profile. Scale, 1 inch $=1,500$ feet. Published in report entitled "Water-power Survey of Surry and Wilkes Counties," in Economic Paper 53, by North Carolina Geological and Economic Survey, 1922.

(a) Fisher River from Dobson-Mount Airy highway bridge, upstream 13 miles (2FB). Profile. Scale, 1 inch $=1,600$ feet. Published in report entitled "Water- 
Power Survey of Surry and Wilkes Counties," in Economic Paper 53, by North Carolina Geological and Economic Survey, 1922.

Horseshoe dam site, about 8 miles above Dobson-Mount Airy bridge.

Scale, 1: 8,000. Contour interval, 10 feet. Topography to 100 feet.

(b) Ararat River from mouth to Douglas Ford, 8 miles (2FB). Profile. Scale, 1 inch $=1,870$ feet. Published in report entitled Water-power Survey of Surry and Wilkes Counties, in Economic Paper 53, by North Carolina Geological and Economic Survey, 1922.

Hiatt's dam site, near bridge on road from Dobson to Pilot Mountain. Scale not shown. Contour intervals 5 and 10 feet. Topography to 30-80 feet.

Matthew's Mill dam site. Scale, 1:2,600. Contour interval, 10 feet. Topography to 90 feet.

Catawba River (head of Wateree and Santee Rivers) from Marion to Connelly Springs, 45 miles (2GA). Plan and profile, 1903. Scales, 1:24,000. Contour interval, 10 feet. Topography to 20-50 feet above water surface. Small-seale profile is published in Water-Supply Paper 115, two sheets. Map not published.

Catawba River (head of Wateree River) from Halltown Road Ford to North Carolina-South Carolina State line $(2 \mathrm{~GB}, 2 \mathrm{GC}, 2 \mathrm{GD})$. Part of map of Catawba and Wateree Rivers from Halltown Road Ford, N. C., to Camden, S. C., 216 miles. Profile compiled from surveys of different dates. Scale, $1 \mathrm{inch}=2$ miles. Published in two sheets. Out of stock.

Mississippi River Basin (3).

(a) Ohio River (3).

(b) South Fork River (head of New River 18 miles upstream to Bowie (3FA). Plan and profile. Scale, 1:29.000. No contours. Published in report entitled "Water-power Survey of Surry and Wilkes Counties," in Economic Paper 53, by North Carolina Geological and Economic Survey, 1922.

(b) Tennessee River. For report by Chief of Engineers, United States Army, on the Tennessee River and tributaries in North Carolina, Tennessee, Alabama, and Kentucky, covering navigation, flood control, power development, and irrigation, see Seventy-first Congress, second session, House Document 328.

(c) Holston River. See Tennessee (p. 99).

(d) Watauga River. See Tennessee (p. 99).

(c) Hiwassee River from North Carolina-Georgia State line to North CarolinaTennessee State line, 58 miles (3UJ). Part of map of Hiwassee River from Hiwassee, Ga., to Apalachia, Tenn. Plan and profile, 1903. Scale, 1:24,000. Contour interval, 10 feet. Topography to 50 feet. Three sheets (two plan, one profile), not published.

(d) Nottely River from mouth to North Carolina-Georgia State line, 18 miles (3UJ). Part of map of Nottely River from mouth to Blairsville, Ga. Plan, 1903. Scale, 1:24,000. Contour interval, 10 feet. Topography to 40-70 feet.

For areas in North Carolina covered by United States Geological Survey standard topographic maps see plate 1.

\section{NORTH DAKOTA}

MISSISSIPPI RIVER BASIN $(5,6)$.

(a) Missouri River from Montana-North Dakota State line to NebraskaIowa State line at Sioux City, 947 miles $(6 \mathrm{E}, 6 \mathrm{~J}, 6 \mathrm{~L})$. Plan by Corps of Engineers, United States Army, 1892. Scale, 1:12,000. Contour interval, 20 feet. Topography varies. Part of map for navigation, showing river from mouth to Three Forks, Mont., 2,551 miles; no contours, topography indicated by hachures. Published by Missouri River Commission, St. Louis, Mo. 
(b) Little Missouri River from North Dakota-South Dakota State line to Medora (6JE, 6JF). Part of a survey extending from 10 miles south of the Wyoming-Montana State line to Medora. Plan and profile, 1945-47. Scale 1:24,000. Contour interval 10 feet on land, 5 feet on water. In preparation.

Nglison River and Lake Winnipeg. (Canada).

(a) Red River of the North from international boundary to Lake Traverse, 455 miles $(50,5 P)$. Plan and profile by Bureau of Public Roads, United States Department of Agriculture. Scale, of plan, 1:53,000; profile, 1 inch $=10$ miles. No topography, but many elevations are given on plan. Published in report on drainage and prevention of overfiow in the valley of the Red River of the North, United States Department of Agriculture Bulletin 1017, 1922.

(b) Assiniboine River (Canada).

(c) Souris (Mouse) River from international boundary to international boundary (all of river within North Dakota), 358 miles (5R). Surveyed by United States Geological Survey in cooperation with North Dakota State, 1925, 1927, 1929. Scale, '1 :24,000. Contour interval, 10 feet. Topography detailed. Published by United States Geological Survey in 15 sheets (12 plan, 3 profile).

For areas in North Dakota covered by United States Geological Survey standard topographic maps see plate 1 .

\section{OHIO}

MIISSISBIPPI RIVER BASIN (3).

(a) Ohio River from Cairo, Ill., to Pittsburgh, Pa., 967 miles. Surveyed for navigation by Corps of Engineers, United States Army at different dates. Maps filed in district offices of Corps of Engineers.

For areas in Ohio covered by United States Geological Survey standard topographic maps see plate 1 .

\section{OKLAHOMA}

For areas in eastern Oklahoma covered by United States Geological Survey standard topographic maps see plate 1.

\section{OREGON}

Silver Lake Basin (10AC).

(a) Silver Creek in T. 30, 31 S., R. 13, 14 E. (10AC). Thompson Valley reservoir site. Plan, 1914. Scale, $1: 48,000$. Contour interval, 5 feet. Topography to 60 feet at dam site. Published in report on Silver Lake irrigation project, by United States Bureau of Reclamation and State of Oregon, 1915.

Dam site. Scale, $1: 24,000$. Contour interval, 5 feet. Topography detailed.

(a) Silver Creek from sec. 22, T. 21 S., R. 26 E., to sec. 33, T. 23 S., R. 27 E. (10AA), Silver Creek reservoir site. Silver Creek reservoir site comprises area above sec. 6, T. 22 S., R. $26 \mathrm{E}$.; scale, $1: 48,000$; contour interval, 10 feet; topography to 100 feet at dam site. Area below reservoir site, at scale $1: 190,080$; contour interval 10 feet and 50 feet; topography covers' wide area for proposed irrigation. Published in report on Harney and Silver Creek irrigation projects, by United States Bureau of Reclamation and State of Oregon, 1916.

Dam site. Scale 1:2,400. Contour interval, 10 feet. Topography to 150 feet.

Malmeur Lake and Harney Lane (10AA).

(a) Silvies River from sec. 15, T. 19 S., R. 31 E., to sec. 25, T. 17 S., R. 31 E. (10AB), Silvies Valley reservoir site. Plan, 1904. Scale, 1: 63,360. Contour 
interval, 5 feet. Topography to $\mathbf{1 0 0}$ feet at dam site. Published in report on Harney and Silver Creek irrigation projects, by United States Bureau of Reclamation and State of Oregon, 1916.

Dam site. Scale, 1:24,000. Contour interval, 10 feet. Topography to 100 feet.

(a) Silvies River in T. 20, 21 S., R. 29 E. (10AB). Lower Silvies reservoir site. Plan, 1916. Scale, 1:63,360. Contour interval, 50 feet. Topography to 100 feet at dam site. Dam site scale, 1:4,800; contour interval, 10 feet. Published in report on Harney and Silver Creek irrigation projects, by United States Bureau of Reclamation and State of Oregon, 1916.

Dam site. Topography to 300 feet.

Dam site. Topography to 70 feet.

(b) Emigrant Creek in T. 20, 21 S., R. 28 E. (10AB). Emigrant Creek reservoir site. Scale, $1: 63,360$. Contour interval, 10 feet and 50 feet. Topography to 150 feet at dam site. Published in report on Harney and Silver Creek irrigation projects, by United States Bureau of Reclamation and State of Oregon, 1916.

Dam site. Scale, 1:3,160. Contour interval, 10 feet. Topography to 150 feet.

Latie Abert Basin (10AD).

(a) Chewaucan River from Paisley, in sec. 24, T. 33 S., R. 18 E., to sec. 1, T. 36 S., R. 17 E., 29 miles (10AD), and dam sites. Plan and profile, 1936. Scale, 1:31,680. Contour interval, 20 feet on land, 5 feet on water. Topography detailed, showing two potential reservoir sites. Dam-site scale, 1:4,800; contour interval, 10 feet. Published in three sheets (one plan, one profile, one dam sites), 1938.

Bear Creek dam site, at mile 9.9 in sec. 28 , T. 34 S., R. 18 E. Topography to 210 feet.

Coffee Pot dam site, at mile 13.6 in sec. 3, 4, T. 35 S., R. 18 E. Topography to 190 feet.

Upper Chewaucan dam site, at mile 23.4, sec. 10, T. 36 S., R. 18 E. Topography to 80 feet.

WARNER LAKES BASIN (10AE).

(a) Deep Creek and tributaries from Adel upstream to sec. 28, T. 40 S., R. 22 E., 21 miles (10AE), Big Valley reservoir site. Plan and profile, 1936. Scale, 1:24,000. Contour interval, 20 feet on land, 5 feet on water. Topography detailed. Published in four sheets (two plan, one profile, one dam sites), 1939.

Big Valley dam site, at mile 15.7 in sec. 4, T. 40 S., R. 22 E. Scale, 1: 4,800. Contour interval, 10 feet. Topography to 100 feet.

(b) Camas Creek from mouth to sec. 8, T. 39 S., R. 21 E., 16 miles (10AE), and dam sites. Dam-site scale, 1:4,800; contour interval, 10 feet. Shown on 1936 survey of Deep Creek and tributaries.

Mud-Camas dam site at mile 8.8 in sec. 5, T. 39 S., R. 22 E. Topography to 230 feet.

Camas dam site at mile 11.0 in sec. 1, T. 39 S., R. 21 E. Topography to 90 feet.

Klamath River from California-Oregon State line to Keno, Oreg., 25 miles (11AE), and dam sites. Plan and profile, 1923. Scale 1:48,000. Contour interval, 25 feet on land, 5 feet on water. Topography detailed. Dam site scale, $1: 2,400$; contour interval, 10 feet. Shown on 2 sheets (1 plan, 1 profile), 1913-23 survey of Klamath River in California and Oregon (16 sheets : 9 plan, 7 profile) ; dam sites shown on 1 sheet in set of 4 showing miscellaneous dam sites on Klamath River in California and Oregon. See also California.

Salt Caves dam site, at mile 178.9. Topography to 160 feet. 
Spencer Creek dam site, at mile 193.1. Topography to 80 feet.

Keno dam site, at mile 200.5. Topography to 60 feet.

Rogue River from point near mouth in sec. 17, T. 36 S., R. 14 W., to point 2 miles above National Creek in sec. 20, T. 29 S., R. 4 E., 198 miles (12RD). Plan and profile, 1923. Scale, 1:31,680. Contour interval, 20 feet on land, 5 feet on water. Topography to 200 feet. Published in 11 sheets ( 6 plan, 5 profile), in 1925.

Rouge River from Lost Creek upstream 3 miles (12RD), Hamaker reservoir site. Plan, 1923. Scale, 1:12,000. Contour interval, 20 feet. Topography to 160 feet at dam site. Dam-site scale, $1: 2,400$; contour interval, 10 feet. Published on 1 sheet in set of 3 showing also dam sites in Rogue River Basin. Out of stock.

Copper Canyon dam site, at mile 20.5 in sec. 11, T. 35 S., R. 12 W. Topography to 180 feet.

Devils Stairs dam site, at mile 43 in sec. 17, T. 33 S., R. 10 W. Topography to 160 feet.

Horseshoe Bend dam site, at mile 54 in sec. 23,26 , T. 33 S., R. 9 W. Topography to 150 feet.

Taylor Creek dam site, at mile 75.3 in sec. 5, T. 35 S., R. 7 W. Topography to 190 feet.

Hell Gate dam site, at mile 78 in sec. 10, T. 35 S., R. 7 W. Topography to 160 feet.

Trail Creek dam site, at mile 143.5 in sec. 10 , T. 34 S., R. 1 W. Topography to 100 feet.

Lost Creek dam site, at mile 154.7 in sec. 26 , T. 33 S., R. 1 E. Topography to $\mathbf{1 7 5}$ feet.

Hamaker dam site, at mile 198 in sec. 20, T. 29 S., R. 4 E. Topography to 140 feet.

(a) Mill Creek from mouth in sec. 32 , T. 32 S., R. 3 E., upstream 5 miles (12RD). Plan, 1923. Scale, $1: 31,680$. Contour interval, 20 feet. Topography detailed. Shown on part of one sheet, 1923 survey of Rogue River.

(a) Bar Creek from mouth in sec. 32, T. 32 S., R. 3 E., upstream 5 miles (12RD). Plan, 1923. Scale, $1: 31,680$. Contour interval, 20 feet. Topography detailed. Shown on part of one sheet, 1923 survey of Rogue River.

(b) Red Blanket Creek from mouth in sec. 4, T. 33 S., R. 3 E., upstream 4 miles (12RD). Plan, 1923. Scale, $1: 31,680$. Contour interval, 20 feet. Topography detailed. Shown on part of one sheet, 1923 survey of Rogue River.

(a) South Fork Rogue River from mouth in sec. 11, T. 33 S., R. 2 E., to sec. 12, T. 33 S., R. 3 E., 9 miles (12RD). Plan and profile, 1923. Scale, 1: 31,680. Contour interval, 20 feet on land, 5 feet on water. Topography to $200-500$ feet. Shown on parts of two sheets (one plan, one profile), 1923 survey of Rogue River.

(b) Middle Fork Rogue River from mouth in sec. 9, T. 33 S., R. 3 E., to sec. 36, T. 32 S., R. 3 E., 5 miles (12RD). Plan and profile, 1923. Scale, 1: 31,680 Contour interval, 20 feet on land, 5 feet on water. Topography to 500 feet. Shown on parts of two sheets (one plan, one profile), 1923 survey of Rogue River.

(a) Lost Creek from mouth in sec. 23, T. 33 S., R. 1 E., upstream 1 mile (12RD). Plan and profile, 1923. Scale, $1: 31,680$. Contour interval, 20 feet. Topography to 200 feet. Shown on parts of two sheets (one plan, one profile), 1923 survey of Rogue River.

(a) Big Butte Creek from mouth in sec. 34, T. 33 S., R. 1 E., to sec. 17, T. 35 S., R. 3 E., 18 miles (12RD). Plan and profile, 1923. Scale, 1:31,680. Contour interval, 20 feet on land, 5 feet on water. Topography to 200 feet. Shown on parts of three sheets (two plan, one profile), 1923 survey of Rogue River. 
(b) MeNeil Creek from mouth in sec. 14, T. 34 S., R. 1 S., upstream 2 miles (12RD). Plan and profile, 1923. Scale 1:31,680. Contour interval, 20 feet. Topography to 20-200 feet. Shown on parts of two sheets (one plan, one profile), 1923 survey of Rogue River.

(b) Neil Creek from mouth in sec. 14, T. 34 S., R. 1 E., upstream 2 miles (12RD). Plan and profile, 1923. Scale, 1:31,680. Contour interval, 20 feet. Topography to 20-200 feet. Shown on parts of two sheets (one plan, one profile), 1923 survey of Rogue River.

(a) Elk Creek from mouth in sec. 31, T. 33 S., R. 1 E., to sec. 20 , T. 33 S., R. 1 E., 3 miles (12RD). Plan and profile, 1923. Scale, 1:31,680. Contour interval, 20 feet. Topography to 200 feet. Shown on parts of two sheets (one plan, one profile), 1923 survey of Rogue River.

(a) Trail Creek from mouth in sec. 3, T. 34 S., R. 1 W., upstream 2 miles (12RD). Plan and profile, 1923. Scale, 1:31,680. Contour interval, 20 fect. Topography to 200 feet. Shown on parts of two sheets (one plan, one profile), 1923 survey of Rogue River.

(a) Little Butte Creek from mouth in sec. 12, T. 36 S., R. 2 W., upstream 1 mile (12RD). Plan and profile, 1923. Scale, 1:31,680. Contour interval, 20 feet. Topography to 100 feet. Shown on parts of two sheets (one plan, one profile), 1923 survey of Rogue River.

(a) Little Butte Creek from mouth to 1 mile above South Fork, 18 miles (12RD), and dam sites. Plan and profile, 1935-1936. Scale, 1:31,680 and 1:12,000. Contour interval 10 and 20 feet on land, 5 feet on water.Topography detailed. Dam-site scale, 1:4,800; contour interval, 10 feet. Published in three sheets (one plan, one profile, one dam sites), 1938.

Brownsboro dam site, at mile 9.5 in sec. 5, T. 36 S., R. 1 E. Topography to 110 feet.

Upper Brownsboro dam site, at mile 13.2 in sec. 11, 14, T. 36 S., R. 1 E. Topography to 140 feet.

Lake Creek dam site at mile 16.5 in sec. 19,20 , T. 36 S., R. 2 E. Topography to 90 feet.

(b) South Fork Little Butte Creek from mouth to Lost Creek, 4 miles (12RD). Shown on one sheet, 1935-36 Survey of Little Butte Creek.

South Fork dam site, at mile 19 in sec. 28,29 , T. 36 S., R. 2 E. Scale $1: 4,800$. Contour interval, 10 feet. Topography to 120 feet.

(a) Evans Creek from mouth to West Fork, 20 miles (12RD), showing reservoir site and dam sites. Plan and profile, 1935-36. Scale, 1:31,680. Contour interval, 20 feet on land, 5 feet on water. Topography detailed above Wimer ; shows creek, highway, and immediately adjacent area below Wimer. Reservoir site in upper portion on scale 1:12,000; contour interval, 10 feet on land, 5 feet on water; topography to 120 feet. Published in two sheets (one plan and profile, one reservoir and dam sites), 1938.

Upper Evans Creek dam site, at mile 18.5 in sec. 25, 26, T. 34 S., R. 3 W.

Scale, 1:2,400. Contour interval, 10 feet. Topography to ' 130 feet.

Lower Evans Creek dam site, at mile 18.0 in sec. 26, T. 34 S., R. 3 W.

Scale, 1:4,800. Contour interval, 10 feet. Topography to 120 feet.

(a) Applegate River from Murphy dam site in sec. 15, T. 37 S., R. 6 W., to sec. 1, T. 38 S., R. 5 W., 12 miles, and from sec. 33, T. 39 S., R. 3 W., to junction of Elliot Creek, 13 miles (12RD). Plan and profile, 1936-37. Scale, 1:31,680. Contour interval, 20 feet on land, 5 feet on water. Topography detailed. Damsite scale, 1 : 4,800; contour interval, 10 feet. Published in four sheets (two plan, one profile, one dam sites), in 1940.

Squaw Creek dam site, in sec. 36, T. 40 S., R. 4 W. Topography to 300 feet. 
French Gulch dam site, in sec. 25, T. 40 S., R. 4 W. Topography to 330 feet.

McKee Bridge dam site, in sec. 33 , T. 39 S., R. 3 W. Topography to 230 feet.

(a) Applegate River from mouth in sec. 20, T. 36 S., R. 6 W., upstream 3 miles (12RD). Plan and profile, 1923. Scale, 1:31,680. Contour interval, 20 feet. Very little topography. Shown on parts of two sheets (one plan, one profile), 1923 survey of Rogue River.

Murphy dam site in sec. 15 , T. 37 S., R. 6 W. Topography to 190 feet.

(b) Carberry Creek from mouth to mile 7 (12RD). Shown on one sheet, 1936-37 survey of Applegate River.

Carberry Creek dam site in sec. 27, T. 40 S., R. 4 W. Scale, 1:2,400. Contour interval, 10 feet. Topography to 230 feet.

(a) Dutcher Creek from mouth in sec. 14, T. 36 S., R. 7 W., upstream 1 mile (12RD). Plan and profile, 1923. Scale, 1:31,680. Contour interval, 20 feet. Topography to $20-60$ feet. Shown on parts of two sheets (one plan, one profile), 1923 survey of Rogue River.

(a) Jump-off Joe Creek from mouth in sec. 14, T. 35 S., R. 7 W., to sec. 5, T. 35 S., R. 5 W., 13 miles (12RD) and dam site. Plan and profile, 1936. Scale, $1: 31,680$. Contour interval, 20 feet on land, 5 feet on water. Topography detailed in upper 3 miles, showing reservoir site; below reservoir site, only creek, road, and immediately adjacent area are shown. Published in one sheet, 1937.

Jump-off Joe Creek dam site, at mile 10.5 in sec. 36 , T. 34 S., R. 6 W.

Scale, $1: 4,800$. Contour interval, 10 feet. Topography to 250 feet.

(a) Jump-off Joe Creek from mouth in sec. 14, T. 35 S., R. 7 W., to sec. 16, T. 35 S., R. 6 W., 5 miles (12RD). Plan and profile, 1923. Scale, 1:31,860. Contour interval, 20 feet. Topography to 20-200 feet. Shown on parts of two sheets (one plan, one profile), 1923 survey of Rogue River.

(a) Taylor Creek from mouth in sec. 5, T. 35 S., R. 7 W., upstream 1 mile (12RD). Plan and profile, 1923. Scale, 1:31,680. Contour interval, 20 feet. Topography to 200 feet. Shown on parts of two sheets (one plan, one profile), 1923 survey of Rogue River.

(a) Grave Creek from Boulder Creek in sec. 6, T. 34 S., R. 4 W., upstream about 4 miles (12RD), showing reservoir site. Plan, 1936. Scale, 1:31,680. Contour interval, 20 feet on land, 5 feet on water. Topography to 200 feet. Published in one sheet, 1938.

Grave Creek dam site, in sec. 6, T. 34 S., R. 4 W., scale, $1: 4,800$. Contour interval, 10 feet. Topography to 210 feet.

(a) Grave Creek from mouth in sec. 1, T. $34 \mathrm{~S}, \mathbf{R} .8 \mathrm{~W}$, upstream 3 miles (12RD). Plan and profile, 1923. Scale, 1:31,680. Contour interval, 20 feet. Topography to 60-200 feet. Shown on parts of two sheets (one plan, one profile), 1923 survey of Rogue River.

(a) Mule Creek from mouth in sec. 9, T. 33 S., R. 10 W., upstream 1 mile (12RD). Plan and profile, 1923. Scale, 1:31,680. Contour interval, 20 feet. Topography to 20-200 feet. Shown on parts of two sheets (one plan, one profile), 1923 survey of Rogue River.

(a) Foster Creek from mouth in sec. 17, T. 34 S., R. 11 W., upstream 1 mile (12RD). Plan and profile, 1923. Scale, 1:31,680. Contour interval, 20 feet. Topography to 60-140 feet. Shown on parts of two sheets (one plan, one profile), 1923 survey of Rogue River.

(a) Shasta Costa Creek from mouth in sec. 6, T. 35 S., R. 11 W., upstream 2 miles (12RD). Plan and profile, 1923. Scale, 1:31,680. Contour interval, 20 
feet. Topography to 100-200 feet. Shown on parts of two sheets (one plan, one profile), 1923 survey of Rogue River.

(a) Illinois River from mouth in sec. 18 , T. 35 S., R. 11 W., to sec. 5 , T. 40 S., R. 8 W., 60 miles (12RD), showing Kerby reservoir, and dam sites. Plan and profile, 1923. Scale, 1:31,680. Contour interval, 20 feet on land, 5 feet on water. Topography to 200 feet. Kerby reservoir scale, $1: 31,680$; contour interval, 10 feet; topography to 120 feet. Dam-site scale (except Kerby), 1:4,800; contour interval, 10 feet. Shown on four sheets (two plan, one showing reservoir, two profile), 1923 survey of Rogue River.

Kerby dam site, at mile 50.1 in sec. 29 , T. 38 S., R. 8 W. Scale, 1:2,400. Topography to 130 feet.

Josephine Creek dam site, at mile 50 in sec. 29 , T. 38 S., R. 8 W. Topography to 160 feet.

Fall Creek dam site, at mile 39.7, approximately in sec. 33, T. 37 S., R. $9 \mathrm{~W}$. Topography to 150 feet.

Collier Bar dam site, at mile 11.9 in T. 36 S., R. 11 W., 1.5 miles below mouth of Collier Creek. Topography to 200 feet. Published only in WaterSupply Paper 638.

(b) East Fork Illinois River from mouth in sec. 21, T. 39 S., R. S W., upstream 3 miles (12RD). Plan and profile, 1923. Scale, 1:31,680. Contour interval, 10 feet. Topography to 10-50 feet. Shown on parts of two sheets (one plan, one profile), 1923 survey of Rogue River.

(b) Reeves Creek from mouth in sec. 28 , T. 38 S., R. 8 W., upstream 2 miles (12RD). Plan and profile, 1923. Scale, 1:31,680. Contour interval, 10 feet. Topography to 10-110 feet. Shown on parts of two sheets (one plan, one profile), 1923 survey of Rogue River.

(b) Josephine Creek from mouth to sec. 11, T. 39 S., R. 9 W., 4 miles (12RD). Plan and profile, 1923. Scale, 1:31,680. Contour interval, 20 feet. Topography to 20-200 feet. Shown on parts of two sheets (one plan, one profile), 1923 survey of Rogue River.

(b) Deer Creek from mouth in sec. 18, T. 38 S., R. 8 W., upstream 1 mile (12RD). Plan and profile, 1923. Scale, 1:31,680. Contour interval, 20 feet. Topography to $160-200$ feet. Shown on parts of two sheets (one plan, one profile), 1923 survey of Rogue River.

(b) Briggs Creek from mouth in T. 37 S., R. 9 W., upstream 1 mile (12RD). Plan and profile, 1923. Scale, 1:31,680. Contour interval, 20 feet. Topography to 20-200 feet. Shown on parts of two sheets (one plan, one profile), 1923 survey of Rogue River.

(b) Klondyke Creek from mouth in T. 36 S., R. 10 W., upstream 1 mile (12RD). Plan, 1923. Scale, 1:31,680. Contour interval, 20 feet. Topography to 20-200 feet. Shown on part of one sheet, 1923 survey of Rogue River.

(b) Collier Creek from mouth upstream 11/2 miles (12RD). Plan and profile, 1923. Scale, 1:31,680. Contour interval, 20 feet. Topography to 20-200 feet. Shown on parts of two sheets (one plan, one profile), 1923 survey of Rogue River.

(b) Silver Creek from mouth upstream 2 miles (12RD). Plan and profile, 1923. Seale, 1:31,680. Contour interval, 20 feet. Topography to $20-200$ feet. Shown on parts of two sheets (one plan, one profile), 1923 survey of Rogue River.

(b) Indigo Creek from mouth upstream 2 miles (12RD). Plan and profile, 1923. Scale, 1:31,680. Contour interval, 20 feet. Topography to 20-200 feet. Shown on parts of two sheets (one plan, one profile), 1923 survey of Rogue River.

(b) Lawson Creek from sec. 29, T. 35 S., R. 11 W., to sec. 1, T. 36 S., R. 12 W., 3 miles (12RD). Plan and profile, 1923. Scale, 1:31,680. Contour interval, 20 
feet. Topography to 20-200 feet. Shown on parts of two sheets (one plan, one profile), 1923 survey of Rogue River.

Coquille River (12RC).

(a) South Fork Coquille River from Powers, Oreg., to sec 8, T. 32 S., R. 10 W., 32 miles (12RC). Plan and profile, 1924-25. Scale, 1:31,680. Contour interval, 20 feet on land, 5 and 20 feet on water. Topography detailed. Published in two sheets (one plan, one profile), 1926.

(a) South Fork Coquille River from sec. 23, T. 32 S., R. 11 W., to point 5 miles upstream (12RC). Ash Swamp reservoir site. Plan, 1924-25. Scale, 1: 12,000. Contour interval, 10 feet on land, 5 feet on water. Topography detailed. Published in one sheet, showing also three dam sites in Coquille River basin, 1926. Out of stock.

Ash Swamp dam site, in sec. 23, T. 32 S., R. 11 W. Scale, 1:4,800. Contour interval, 10 feet. Topography to 200 feet.

(a) North Fork Coquille River in NE1/1 sec. 23, T. 28 S., R. 12 W. (12RC). Fairview dam site. Shown on one sheet, 1924-25 survey of South Fork Coquille River. Out of stock.

Fairview dam site. Scale, 1:4,800. Contour interval, 10 feet. Topography to 200 feet.

(b) East Fork Coquille River from sec. 5 to sec. 9, T. 28 S., R. 10 W., 2 miles (12RC), showing also conduit location from Brewster Valley dam site to point on Cherry Creek in sec. 3, T. 28 S., R. 11 W. Plan and profile, 1924-25. Scale, 1:31,680. Contour interval, 50 feet on land, 10 feet on water. Topography detailed. Shown on two sheets, 1924-25 survey of South Fork Coquille River. Out of stock.

Brewster Valley dam site, in SE1/4 sec. 9, T. 28 S., R. 10 W. (12RC). Scale, 1:4,800. Contour interval, 10 feet. Topography to 150 feet. Out of stock.

UMPQUA RIVER from Elkton in sec. 30, T 22 S., R. 7 W., to confluence of North Umpqua River and South Umpqua River in sec. 31, T. 26 S., R. 6 W., 62 miles (12RB). Plan and profile, 1914. Scale, 1:31,680. Contour interval, 25 feet on land, 5 feet on water. Topography to about 150 feet. Complete survey includes also North Umpqua River to Boulder Creek, Oreg., Boulder Creek to Lake Creek, and Lake Creek to Diamond Lake, Oreg. Published in Water-Supply Paper 379.

UMPQUA RIVER from Scottsburg to confluence of North Umpqua River and South Umpqua River, 83 miles (12RB), including North Umpqua River and tributaries. Plan and profile, 1914 and 1924. Scale, 1:31,680. Contour interval, 25 feet on land, 5 feet on water. Topography detailed. Published in nine sheets (five plan, four profile), including the 1914 survey of Umpqua River above Elkton, with added detailed topography, 1926.

Umpqua River from sec. 16, T. 25 S., R. 7 W., to sec. 33, T. 26 S., R. 6 W., 16 miles (12RB), showing Coles Valley reservoir site. Plan, 1924. Scale, 1:12,000. Contour interval, 10 feet on land, 5 feet on water. Topography detailed. Shown on 1 sheet, 1914-24 survey of Umpqua River and tributaries. Coles Valley reservoir site shown also on 1914 survey of Umpqua River, published in Water-Supply Paper 379.

Umpqua River dam sites. Surveyed, 1924. Scale, 1:4,800. Contour interval, 10 feet. Shown in set of seven sheets entitled "Miscellaneous Reservoir and Dam Sites, Umpqua River Above Scottsburg, Oreg., North Umpqua and tributaries," as part of the 1914-24 survey of Umpqua River and tributaries.

Scottsburg dam site, in sec. 7, T. 22 S., R 9 W. Topography to 75 feet.

Sawyer Rapids dam site, in sec. 4, T. 22 S., R. 8 W. Topography to 100 feet. 
Kelly-Smith Ferry dam site, in sec. 5, 8, T. 23 S., R. 7 W. Topography to 100 feet.

Smith Ferry dam site, in sec. 30, T. 23 S., R. 7 W. Topography to 150 feet.

Kellogg dam site, in sec. 11, T. $24 \mathrm{~S}$, R. $7 \mathrm{~W}$. Topography to 120 feet.

Coles Valey dam site at mile 47.9 in sec. 16, T. 25 S., R. 7 W. Topography to 400 feet above sea level, or 110 feet above water surface at dam site.

(a) North Umpqua River from mouth in sec 31, T. $26 \mathrm{~S}$., R. 6 W., to Boulder Creek, 68 miles (12RB). Plan and profile, 1914. Scale, 1:31,680. Contour interval, 25 feet on land, 5 feet on water. Topography to 150 feet. Published in Water-Supply Paper 379.

(a) North Umpqua River from Boulder Creek to Bradley Creek, 32 miles (12RB). Plan and profile by United States Geological Survey, 1914. Scale, $1: 48,000$. Contour interval, 25 feet on land, 5 feet on water. Topography to 100 feet. Shown on two sheets (one plan, one profile), 1914 survey of Umpqua River and tributaries, published in Water-Supply Paper 379.

(a) North Umpqua River from mouth in sec. 31, T. 26 S., R. 6 W., to Bradley Creek, 98 miles (12RB). Plan and profile, 1914 and 1924. Scale, 1:31,680 and 1 : 48,000. Contour interval, 25 feet on land, 5 feet on water. Shown on 1914-24 survey of Umpqua River. Topography shows river and immediately adjacent areas.

(a) North Umpqua River Dam sites. Surveyed 1924. Scale, 1:4,800. Contour interval, 10 feet. Shown in set of seven sheets entitled "Miscellaneous Reservoir and Dam Sites, Umpqua River Above Scottsburg, Oreg., North Umpqua River and Tributaries," 1914-24 survey of Umpqua River and tributaries.

Winchester dam site, in secs. 19, 20, T. 26 S., R. 5 W. Topography to 100 feet.

Oak Creek dam site, in sec. 11, T. 26 S., R. 5 W. Topography to 75 feet.

Horseshoe Bend dam site, in sec. 17, T. 26 S., R. 4 W. Topography to 75 feet.

Glide dam site, in sec. 19 , T. 26 S., R. 3 W., just below mouth of Little River. Topography to 100 feet, showing conduit location from Glide dam site to Horseshoe Bend dam site, along the 720 -foot contour.

Clark ranch dam site, in sec. 21, T. 26 S., R. 2 W. Topography to 100 feet.

Steamboat dam site, in about sec. 9, T. 26 S., R. 1 E. Topography to 225 feet.

Copeland Creek dam site, in sec. 21 , T. 26 S., R. 2 E. Topography to 200 feet.

Soda Springs dam site, in T. 26 S., R. 3 E., at mile 151.7 above Scotts burg. Topography to 225 feet.

(b) Lake Creek from mouth to Diamond Lake, 12 miles (12RB). Plan and profile, 1914. Scale, 1:48,000. Contour interval, 25 feet on land, 5 feet on water. Very little topography. Published in Water-Supply Paper 379. Shown on two sheets (one plan, one profile), 1914-24 survey of Umpqua River and tributaries.

Dam site at outlet of Diamond Lake. Scale, 1:4,800. Contour interval, 10 feet. Topography to 50 feet.

(b) Clearwater River from mouth to Lava Creek, 12 miles (12RB). Plan and profile, 1924. Scale, 1:31,680. Contour interval, 20 feet on land, 5 feet on water. Topography detailed. Shown on two sheets (one plan, one profile), 1914-24 Survey of Umpqua River and tributaries.

(b) Fish Creek from mouth to Rough Can Creek, 9 miles (12RB). Plan and profile, 1924. Scale, 1:31,680. Contour interval, 20 feet on land, 5 feet on 
water. Topography to 200 feet. Shown on two sheets (one plan, one profile), 1914-24 survey of Umpqua River and tributaries.

$(b)$ Steamboat Creek from mouth upstream 10 miles (12RB). Plan and profile, 1924. Scale, 1:31.680. Contour interval, 20 feet on land, 5 feet on water. Topography to 200 feet. Shown on two sheets (one plan, one profile), 1914-24 survey of Umpqua River and tributaries.

(a) South Umpqua River from sec. 16, T. 30 S., R. 4 W., to sec. 27 , T. 29 S., R. 1 W., 26 miles (12RB), and dam sites. Plan and profile, 1936. Scale, $1: 24,000$. Contour interval, 20 feet on land, 5 feet on water. Topography detailed. Damsite, scale, 1:4,800; contour interval, 10 feet. Published in three sheets (two plan, showing also dam sites, and one profile), 1938.

Tiller dam site, at mile 17.1 in sec. 27, T. 30 S., R. 2 W. Topography to 270 feet.

Days Creek dam site, at mile 0.2 in sec. 21 , T. 30 S., R. 4 W. Topography to 250 feet.

Shively dam site, at mile 2.9 in sec. 23,24, T. 30 S., R. 4 W. Topography to 210 feet.

(b) Jackson Creek from mouth upstream to mile 4 (12RB). Shown on two sheets (one plan, one profile), 1936 survey of South Umpqua River.

(b) Cow Creek from sec. 2, T. 32 S., R. 4 W., to sec. 2 , T. 32 S., R. 3 W., 8 miles (12RB), and dam sites. Plan and profile, 1936. Scale, 1:24,000. Contour interval, 20 feet on land, 5 feet on water. Topography detailed. Dam-site scale, 1: 4,800; contour interval, 10 feet. Published in one sheet, showing also three dam sites.

Dismal Creek dam site, at mile 4.4 in sec. 5, T. 32 S., R. 3 W. Topography to 170 feet.

Upper Meadows dam site, at mile 0.6 in sec. 1, T. 32 S., R. 4 W. Topography to 140 feet .

Lower Meadows dam site, at mile 0.0 in sec. 2, T. 32 S., R. 4 W. Topography to 150 feet.

(a) Calapooya Creek from mouth to sec. 4, T. 25 S., R. 5 W., 13 miles (12RB). Surveyed, 1924. Scale, 1:12,000. Contour interval, 10 feet. Topography detailed. Shown on two sheets in set of seven showing miscellaneous reservoir and dam sites, 1914-24 survey of Umpqua River and tributaries.

(a) Mill Creek from mouth in sec. 15, T. 22 S., R. 10 W., to Loon Lake, 8 miles (12RB). Plan and profile, 1924. Scale, 1:31,680. Contour interval, 20 feet on land, 5 feet on water. Topography to 50-200 feet (carried to elevation of water surface in Loon Lake). Shown on one sheet of 1914-24 survey of Umpqua River and tributaries.

Dam site at outlet of Loon Lake. Scale, 1:4,800. Contour interval, 10 feet. Topography to 50 feet.

(b) Loon Lake, 2 miles (12RB), potential reservoir site. Plan, 1924. Scale, 1: 12,000. Contour interval, 10 feet. Topography to 50 feet. Published on one sheet in set of seven showing miscellaneous reservoir and dam sites, 1914-24 survey of Umpqua River and tributaries.

(c) Lake Creek. Small reservoir site on Lake Creek near headwaters. Surveved, 1926. Scale, $1: 31,680$. Not published.

Siletz River from tide water in sec. 7, T. 9 S., R. 10 W., to junction of North Fork and South Fork in sec. 18, T. 8 S., R. 8 W., 45 miles (12RA), and tributaries. Plan and profile, 1925. Scale, 1:31,680. Contour interval, 20 feet on land, 5 feet of water. Topography to 200 feet. Published in three sheets (two plan, one profile), 1926. Out of stock.

Falls dam site, in sec. 24 , T. 8 S., R. 9 W. Scale, $1: 4,800$. Contour interval, 10 feet. Topography to 180 feet. 
(a) South Fork Siletz River from mouth upstream 11 miles (12RA), showing reservoir site near Valsetz. Scale, 1:31,680. Contour interval, 20 feet. Topography detailed. Shown on one sheet, 1925 survey of Siletz River and tributaries.

(a) North Fork Siletz River upstream 2 miles (12RA). Shown on 1 sheet, 1925 survey of Siletz River and tributaries.

NeHalem River from near Mohler in sec. 36, T. 3 N., R. 10 W., to Timber in sec. 22 , T. 3 N., R. 5 W., 102 miles (12RA), and dam sites. Surveyed, 1934 and 1936. Scale, 1:31,680. Contour interval, 20 feet on land, 5 feet on water. Topography detailed. Dam-site scale, 1:4,800; contour interval, 10 feet. Published in seven sheets (four plan, three profile).

Stonehill dam site, at mile 4.9 in sec. 34 , T. 3 N., R. 9 W., Topography to 80 feet.

Nehalem Falls dam site, at mile 8 in sec. 22, 27, T. 3 N., R. 9 W. Topography to 340 feet.

Salmonberry dam site, at mile 15.5 in sec. 10, T. 3 N., R. 8 W. Topography to 240 feet.

Elsie dam site, at mile 30.4 in sec. 4, T. 4 N., R. 7 W. Topography to to 250 feet.

Tideport dam site, at mile 36.9 in sec. 23,24 , T. 5 N., R. 7 W. Topography to 210 feet.

Columbia River. For surveys of Columbia River, see Washington (p. 112).

(a) Snake River from Lewiston, Idaho, to Huntington, Oreg. See Idaho (p. 37). See also plate one for work in progress on quadrangle maps covering Snake River.

(b) Owyhee River from sec. 8, T. 32 S., R. 42 E., to sec. 4, T. 31 S., R. 41 E., about 9 miles (12HE), Duncan Ferry reservoir site. Plan by United States Bureau of Reclamation, 1906. Scale, 1:12,000. Contour interval, 10 feet. Topography to 100 feet. Scale of published map, 1:63,360; contour interval. 10 feet; topography to 100 feet at dam site. Dam-site scale, 1:2,400; contour interval, 10 feet and 50 feet; topography to 300 feet. Published in report entitled "Malheur and Owyhee Projects, Irrigation and Drainage," by United States Bureau of Reclamation and State of Oregon, 1916.

(b) Owyhee River in T. 26 S., R. 43, 44 E. (12HE), Red Butte reservoir site. Plan by United States Bureau of Reclamation and State of Oregon, 1904. Scale, 1:63,360. Contour interval, 10 feet. Topography to 150 feet at dam site. Dam-site scale, 1:7,200; contour interval, 10 feet; topography to 200 feet. Published in report entitled "Malheur and Owyhee Projects, Irrigation and Drainage," by United States Bureau of Reclamation and State of Oregon, 1916.

(b) Owyhee River in sec. 14, T. 21 S., R. 45 E. (12HE), Owyhee Canyon diversion dam site. Surveyed by United States Bureau of Reclamation and State of Oregon, 1904. Scale, 1:9,600. Contour interval, 10 feet. Topography to 160 feet. Published in report entitled "Malheur and Owyhee Projects, Irrigation and Drainage," by United States Bureau of Reclamation and State of Oregon, 1916.

(b) Malheur River from sec. 17, T. 19 S., R. 43 E., to sec. 34, T. 20 S., R. 41 E., about 15 miles (12HH), Harper reservoir site. Plan by United States Bureau of Reclamation, 1909. Scale, 1:31,680. Contour interval, 50 feet. Topography to about 150 feet at dam site. Not published.

(c) Middle Fork Malheur River from sec. 8, T. 23 S., R. 37 E., to sec. 27, T. 21 S., R. 36 E., 10 miles (12HH), Warm Springs reservoir site. Plan by United States Bureau of Reclamation, 1905. Scale, 1:12,000. Contour interval, 5 feet. Topography to 100 feet. Scale of published map, 1:64,000; contour interval, 10 feet; topography to 100 feet at dan site. Dam-site scale, 1:2,400; contour interval, 5 feet; topography to 180 feet. Published in report entitled "Malheur 
and Owyhee Projects, Irrigation and Drainage," by United States Bureatu of Reclamation and State of Oregon, 1916.

(c) North Fork Malheur River from sec. 22, T. 19 S., R. 37 E., to sec. 4, T. 19 S., R. 37 E., about 4 miles $(12 \mathrm{HH})$, Agency Valley reservoir site. Plan by United States Bureau of Reclamation, 1909. Scale, 1:12,000. Contour interval, 10 feet on land, 5 feet on water. Topography to about 75 feet. Scale of published map, 1:63,360; contour interral, 10 feet; topography to 90 feet at dam site. Dam-site scale, 1:2,400; contour interval, 10 feet; topography to 100 feet. Published in report entitled "Malheur and Owyhee Projects, Irrigation and Drainage," by United States Bureau of Reclamation and State of Oregon, 1916.

(b) Imnaha River from Skookum Creek downstream 4 miles (12HM), showing Coverdale reservoir site. Plan, 1930. Aneroid datum. Scale, 1:31,680. Contour interval, 20 feet. Topography to 200 feet at dam site. Dam-site scale, $1: 4,800$. Not published.

(a) Grande Ronde River from confluence with Wallowa River at Rondowa upstream 14 miles (12HP). Plan, 1945. Scale, 1:24,000. Contour interval, 20 feet on land, 5 feet on water. Topography to 2,600 -foot contour. In preparation.

(b) Grande Rỏnde River from mouth in Washington to mouth of Wallowa River in Oregon, 37 miles in Washington, 44 miles in Oregon (12HP). Plan and profile, 1930. Scale, $1: 31,680$. Contour interval, 20 feet on land, 5 feet on water. Topography detailed. Published in seven sheets (three plan, three profile, one showing dam sites), including Wallowa River, Minam River and dam sites, 1934.

(c) Catherine Creek from sec. 7 to sec. 21, T. 5 S., R. 41 E. (12HP) showing reservoir site. Plan, 1933. Scale, 1: 31,680. Contour interval, 20 feet. Topography to 260 feet at dam site. Published in one sheet, showing also dam sites, 1934.

Three alternative dam sites in sec. 7, T. 5 S., R. 41 E. Scale, 1:4,800. Contour interval, 10 feet. Topography to 200 feet at dam site.

(c) Wallowa River from mouth to Wallowa, 22 miles (12HO). Plan and profile, 1930. Scale, 1:31,680. Contour interval, 20 feet on land, 5 feet on water. Topography detailed. Shown on two sheets (1 plan, one profile), in 1930 survey of Grande Ronde River.

(d) Minam River from mouth to sec. 10, T. 1 S., R. 41 E., 11 miles (12HO). Plan and profile, 1930. Scale, $1: 31,680$. Contour interval, 20 feet on land, 5 feet on water. Topography detailed. Published on two sheets (one plan, one profile) in set of seven, 1930 survey of Grand Ronde River.

(a) Walla Walla River above Freewater, Oreg. (12MB), including North Fork, and South Fork, and miscellaneous dam sites. Plan and profile, 1931-32. Scale, 1:31,680. Contour interval, 20 feet on land, 5 feet on water. Topography detailed. Published in four sheets (two plan, one profile, one dam site), 1933.

(a) Walla Walla River from Freewater, Oreg., to junction of North Fork and South Fork in sec. 22, T. 5 N., R. 36 E., 61/2 miles (12MB). Plan and profile, 1931-32. Scale, 1:31,680. Contour interval, 20 feet on land, 5 feet on water. Topography detailed. Published on two sheets (one plan, one profile), in set of four, 1931-32 survey of Walla Walla River above Freewater, Oreg., 1933.

Rock dam site, in sec. 18, T. 5 N., R. 36 E. Scale, 1:4,800. Contour interval, 10 feet. Topography to 180 feet.

(b) North Fork Walla Walla River from mouth to sec. 6, T. 5 N., R. 39 E., 18 miles (12MB). Plan and profile, 1931-32. Scale, 1:31,680. Contour interval, 20 feet on land. 5 feet on water. Topography detailed. Published on three sheets (two plan, one profile) in set of four, 1931-32 survey of Walla Walla River above Freewater, Oreg., 1933. 
(b) South Fork Walla Walla River from mouth to north boundary of T. 5 N., R. 39 E., 25 miles (12MB). Plan and profile, 1931-32. Scale, 1:31,680. Contour interval, 20 feet on land, 5 feet on water. Topography detailed. Published in three sheets (two plan, one profile), in set of four, 1931-32 survey of Walla Walla River above Freewater, Oreg., 1933.

Three dam sites, at mile 15.4 , mile 16.5 , and mile 17.3 , respectively.

Scale, 1: 4,800. Contour interval, 10 feet. Topography to about 300 feet.

Mileage from Freewater, Oreg., on Walla Walla River.

(a) Umatilla River from sec. 2 , T. 2 N., R. 34 E., to forks, about 22 miles (12MC). Plan and profile, 1934. Scale, 1:12,000. Contour interval, 10 and 20 feet. Topography detailed. Dam-site scale, 1:4,800: contour interval, 10 feet. Published in three plan sheets, 2 also showing dam sites, 1938.

Ryan Creek dam site, in sec. 21,22 , T. 3 N., R. 36 E. Topography to 250 feet.

Bingham Springs dam site, in sec. 17, T. 3 N., R. 37 E. Topography to 320 feet.

(a) John Day River from sec. 20, T. 12 S., R. 26 E., to sec. 3, T. 13 S., R. 27 E. (12MD), Dayville reservoir site. Plan, 1915. Scale, 1:63,360. Contour interval, 10 and 50 feet. Topography to 175 feet at dam site. Dam-site scale, $1: 4,800$; Contour interval, 25 feet; topography to 200 feet. Published in report on John Day irrigation project by United States Bureau of Reclamation and State of Oregon, 1916.

(a) John Day River and North Fork, from sec. 24, T. 9 S., R. 25 E., to sec. 30, T. 10 S., R. 26 E., on John Day River, and to sec. 3, T. 9 S., R. 27 E., on North Fork John Day River (12MD, 12ME), Spray reservoir site. Plan, 1910. Scale, 1:126,720. Contour interval, 50 feet. Topography to 150 feet. Published in report on John Day irrigation project by United States Bureau of Reclamation and State of Oregon, 1916.

(a) John Day River from sec. 11, T. 10 S., R. 20 E., to sec. 8, T. 9 S., R. 23 E. (12MF), Twickenham reservoir site. Plan, 1908. Scale, 1:173,000. Contour interval 50 feet. Topography to 150 feet at dam site. Dam-site scale, 1:17,150; contour interval, 10 feet; topography to 150 feet. Published in report on John Day irrigation project by United States Bureau of Reclamation and State of Oregon, 1916.

(a) John Day River from sec. 34, T. 9 S., R. 20 E., to sec. 18, T. 7 S., R. 19 E. (12MF), Clarno reservoir site. Plan, 1914. Scale, 1:96,000. Contour interval, 10 and 50 feet. Topography to 225 feet at dam site. Dam-site scale, $1: 14,750$; contour interval, 5 feet; topography to 225 feet. Published in report on John Day irrigation project by United States Bureau of Reclamation and State of Oregon.

(a) John Day River in sec. 27, T. 3 s., R. 18 E., (12MF), Bull Basin dam site. Plan, 1914. Scale 1:4,800. Contour interval, 5 feet. Topography to 260 feet. I'ublished in report on John Day irrigation project by United States Bureau of Reclamation and State of Oregon, 1916.

(a) John Day River in sec. 14, 15, 22, 23, T. 3 S., R. 18 E., (12MF), Jack Knife dam site. Plan, 1914. Scale, 1: 4,800. Contour interval, 5 and 25 feet. Topography to 325 feet. Published in report on John Day irrigation project, by United States Bureau of Reclamation and State of Oregon, 1916.

(a) John Day River in sec. 1, 12, 13, T. 2 N., R. 18 E., and sec. 6, 7, 18, T. 2 N., R. 19 E. (12MF), Tenmile Falls power site Plan, 1915 Scale, 1:24,000. Contour interval; 20 feet. Topography detailed. Published in report on John Day irrigation project by United States Bureau of Reclamation and State of Oregon, 1916.

(a) John Day River from mouth in sec. 23, T. 3 N., R. 17 E., to mouth of Middle Fork in sec. 30, T. 9 S., R. 26 E., 180 miles (12MF). Plan and profile, 1909 . Scale, 
1:31,680. Conotur interval, 25 feet on land, 5 feet on water. Topography to 25-75 feet. Published in Water-Supply Paper 377.

(b) Rock Creek from sec. 15 to sec. 35, T. 3 S., R. 22 E., (12MF), Devils Gap reservoir site. Plan, 1911. Scale, 1:24,000. Contour interval, 20 and 25 feet. Topography to $\mathbf{1 5 0}$ feet at dam site. Published in report on John Day irrigation project by United States Bureau of Reclamation and State of Oregon, 1916.

(a) Deschutes River from mouth in sec. 23, T. 2 N., R. 15 E., to Pringle Falls in sec. 23, T. 21 S., R. 9 E., 217 miles (12MH, 12MK), including West Fork. Plan and profile, 1911. Scale, $1: 31,680$. Contour interval 25 feet on land, 5 feet on water. Topography to 50-700 feet. Published in Water-Supply Paper 344.

(b) West Fork Deschutes River from sec. 7, T. 20 S., R. 11 E., to Pringle Falls in sec. 23, T. 21 S., R. 9 E., 36 miles (12MH). Plan and profile, 1911. Scale, $1: 31,680$. Contour interval, 5 feet on land and water. Topography to about 80 feet. Published in Water-Supply Paper 344.

(b) East Fork Deschutes River from mouth in sec. 7, T. 20 S., R. 11 E., to sec. 9. T. 2 .2 S., R. 10 E., 31 miles (12MH). Plan and profile, 1911. Scale, $1: 31,680$. Contour interval, 5 feet. Topography to about 50 feet. Published in WaterSupply Paper 344.

(c) Paulina Creek from sec. 18, T. 21 S., R. 11 E., to sec. 12, T. 21 S., R. 10 E., 1 mile (12MH). Plan, 1911. Scale, 1:31,680 Contour interval, 5 feet. Very little topography. Published in Water-Supply Paper 344.

(b) Fall River from mouth in sec. 3, T. 21 S., R. 10 E., to sec. 32, T. 20 S., R. 10 E., 5 miles (12MH). Flan and profile, 1911. Scale, 1:31,680 Contour interval, 5 feet. Topography to about 50 feet. Published in Water-Supply Paper $3+4$.

(b) Crooked River from mouth to trail crossing in sec. 33, T. 13 S., R. 13 E., about 20 miles (12MJ). Plan and profile, 1925. Scale, 1:12,000. Contour interval, 25 feet on land, 5 feet on water. Topography to 100-500 feet. Published in three sheets (two plan, one profile), 1926.

(c) Ochoco Creek from mouth to sec. 6, T. 15 S., R. 17 E., 9 miles (12 MJ). Plan, 1914. Scale, 1:63,360. Contour interval, 20 and 100 feet. Topography detailed. Published in report on Ochoco irrigation project and Crooked River investigation, by United States Bureau of Reclamation and State of Oregon, 1915.

(c) Ochoco Creek from sec. 5, T. 15 S., R. 17 E., to sec. 36, T. 14 S., R. 17 E. (12MJ), reservoir site. Plan, 1914. Scale, 1:24,000 Contour interval, 10 feet. Topography to 150 feet at dam site. Dam-site scale, $1: 3,600$; contour interval, 5 feet; topography to 130 feet. Published in report on Ochoco irrigation project and Crooked River investigation by United States Bureau of Reclamation and State of Oregon, 1915.

(b) Metolius River from mouth in sec. 22 , T. 11 S., R. 12 E., to sec. 22 , T. 13 S., R. 9 E., 41 miles (12MK). Plan and profile, 1912. Scale, 1:31,680. Contour interval, 25 feet on land, 5 feet on water. Topography to 25-200 feet. Published in Water-Supply Paper 344.

(c) Lake Creek from mouth in sec. 10, T. 13 S., R..9 E., to sec. 34, T. 13 S., R. 8 E., Blue Lake, 8 miles (12MK), including Suttles Lake. Plan and profile, 1912. Scale, 1:31,680. Contour interval, 25 feet on land, 5 feet on water. Topography to 25-150 feet. Published in Water-Supply Paper 344.

(b) Shitike Creek from mouth in sec. 30, T. 9 S., R. 13 E., to sec. 30, T. 9 S., R. 10 E., 20 miles (12MK). Plan and profile by Office of Indian Affairs, 1912. Scale, 1:24,000 No contours. Topography indicated by shading. Profile extends to Harvey Lake, 32 miles above mouth. Not published.

(b) Shitike Creek from mouth in sec. 30, T. 9 S., R. 13 E., to sec. 18, T. 9 S., R. 12 E., 7 miles (12MK). Plan and profile by Office of Indian Affairs, 1912. Scale, 1:24,000. Contour interval, 25 feet. Topography detailed. Not published. 
(b) Warm Springs River from mouth in sec. 21 , T. 8 S., R. 14 E., to sec. 4 T. 7 S., R. 9 E., 41 miles (12MK). Plan and profile by Office of Indian Affairs, 1912. Scale, 1:24,000. No contours. Topography indicated by shading. Not published.

(c) Badger Creek from mouth in sec. 21, T. 7 S., R. 11 E., to sec. 31, T. 7 S., R. 10 E., 9 miles (12MK). Plan and profile by Office of Indian Affairs, 1912. Scale, 1:24,000. No contours. Topography indicated by shading. Not published.

(c) Mill Creek from mouth in sec. 13, T. 8 S., R. 11 E., to sec. 12, T. 9 S., R. $8 \mathrm{E}$., 22 miles (12MK). Plan and profile by Office of Indian Affairs, 1912. Scale, $1: 24,000$. No contours; topography indicated by shading. Not published.

(c) Beaver Creek from mouth in sec. 18, T. 8 S., R. 12 E., to sec. 36, T. 6 S., R. 10 E., 13 miles (12MK). Plan and profile by Office of Indian Affairs, 1912. Scale, 1:24,000. No contours. Topography indicated by shading. Not published.

(b) White River from mouth in sec. 9, T. 4 S., R. 14 E., to sec. 20 , T. 4 S., R. 13 E., 9 miles (12MK). Plan and profile, 1914. Scale, 1:31,680. Contour interval 25 feet on land, 5 feet on water. Topography to about 100 feet. Published in Water-Supply Paper 378.

(b) White River from mouth to Mount Hood Loop Highway, 45 miles (12MK). Plan and profile, 1914 and 1932. Scale, 1:31,680. Contour interval, 20 and 25 feet on land, 5 feet on water. Topography detailed. Published in three sheets (two plan, one profile), 1933.

(a) Hood River from mouth to junction of East Fork and Middle Fork, 14 miles (12MN). Revision of 1913 survey, 1933. Scale, 1:31,680. Contour interval, 25 feet on land, 5 feet on water. Topography detailed. Revision, with new surveys on major tributaries in 1933,1935 , and 1936 , incorporated in set of four sheets (two plan, two profile), published 1939.

(b) East Fork Hood River from mouth to sec. 20, T. 2 S., R. 10 E., 17 miles (12MN). Revision of 1913 survey, with additional surveys upstream, 1933. Scale, $1: 31,680$. Contour interval, 20 and 25 feet on land, 5 feet on water. Shown on 1939 survey of Hood River.

(b) Middle Fork Hood River from mouth to Eliot Branch, 9 miles (12MN). Plan, 1935. Scale, 1:31,680. Contour interval, 20 feet. Topography detailed. Shown on 1939 survey of Hood River.

(b) West Fork Hood River from mouth to sec. 13, T. 1 S., R. 8 E., 13 miles $(12 \mathrm{MN})$. Revision of 1913 survey, with additional surveys upstreams, 1983 and 1935. Scale, $1: 31,680$. Contour interval, 20 feet. Topography detailed. Shown on 1939 survey of Hood River.

(c) Lake Branch from junction with West Fork Hood River to Lost Lake, 12 miles (12MN). Plan, 1935 and 1936. Scale, 1:31,680. Contour interval, 20 feet. Topography detailed. Shown on 1939 survey of Hood River.

(a) Sandy River from sec. 17, T. 2 S., R. 8 E., to sec. 18, T. 2 S., R. 6 E., 18 miles (12MO). Plan and profile, 1913. Scale, 1:31,680. Contour interval, 25 feet on land, 5 feet on water. Topography to 25-75 feet. Published in Water-Supply Paper 318 .

(a) Sandy River from mouth in sec. 19, T. 1 N., R. 4 E., to Marmot, sec. 18, T. 2 S., R. 6i E., 30 miles (12MO). Plan and profile, 1926. Scale, 1:31,680. Contour interval, 20 feet on land, 5 feet on water. Topography to 150 feet. Published in two sheets (one plan, showing also dam site, and one profile), 1927.

Swimming Hole dam site, at mile 17.9 in sec. 30 , T. 1 S., R. 5 E. Scale, 1: 4,800. Contour interval, 10 feet. Topography to 110 feet.

(b) Zigzag River from sec. 33, T. 2 S., R. 7 E., to sec. 17, T. 3 S., R. 8 E., 6 miles (12MO). Plan and profile, 1913. Scale, 1:31,680. Contour interval, 25 feet on 
land, 5 feet on water. Topography to 25-75 feet. Published in Water-Supply Paper 348.

(c) Camp Creek from sec. 13, T. 3 S., R. 7 E., to sec. 17, T. 3 S., R. 8 E., 2 miles (12MO). Plan and profile, 1913. Scale, $1: 31,680$. Contour interval, 25 feet on land, 5 feet on water. Very little topography. Published in Water-Supply Paper 348.

(c) Still Creek from sec. 2 , T. 3 S., R. 7 E., to sec. 29 , T. 3 S., R. 8 E., 5 miles (12MO). Plan and profile, 1913. Scale, $1: 31,680$. Contour interval, 25 feet on land, 5 feet on water. Very little topography. Published in Water-Supply Paper 348 .

(b) Bull Run River from mouth on north line of sec. 31, T. 1 S., R. 5 E., to town of Bull Run, 2 miles (12MO). Plan and profile, 1926. Scale, 1:31,680. Contour interral, 20 feet. Topography to 100 feet. Shown on 1926 survey of Sandy River from mouth to Marmot.

(a) Willamette River (12N).

(b) Middle Fork Willamette River from sec. 12, T. 21 S., R. 2 E., to sec. 28, T. 24 S., R. 5 E., 39 miles (12NB). Plan and profile, 1913-14. Scale, $1: 31,680$. Contour interval, 25 feet on land, 5 feet on water. Topography to $\mathbf{2 5 - 1 5 0}$ feet. Published in Water-Supply Paper 349, and 378.

(b) Middle Fork Willamette River from Lookout Point in sec. 35, T. 20 S., R. 2 E., to point about 1 mile above Hills Creek in sec. 2, T. 22 S., R. 3 E., 13 miles (12NB), Lookout Point reservoir site. Plan, 1935. Scale, 1:12,000. Contour interval, 10 feet on land, 5 feet on water. Topography to 1,300 feet. Published in four sheets (three plan, and one showing Lookout Point dam site). 1937.

Lookout Point dam site, in sec. 35, T. 20 S., R. 2 E. Scale, 1: 2,400. Contour interval, 10 feet. Topography to 450 feet.

(b) Middle Fork Willamette River from Coast Fork in sec. 11, T. 18 S., R. 3 W., to mouth of North Fork in sec. 12, T. 21 S., R. 2 E., 40 miles (12NB). Plan and profile, 1926. Scale, $1: 31,680$. Contour interval, 20 feet on land, 5 feet on water. Topography to 100 feet or more. Published in two sheets (one plan, one profile), $192 \%$.

(c) Salt Creek from sec. 22 , T. 21 S., R. 3 E., to the falls, 22 miles (12NB). Plan and profile, 1913. Scale, 1:31,680. Contour interval, 25 feet on land, 5 feet on water. Topography to 150 feet. Published in Water-Supply Paper 349.

(c) Salmon Creek from sec. 16, T. 21 S, R. 3 E., upstream 18 miles (12NB). Plan and profile, 1913. Scale, 1:31,680. Contour interral, 25 feet on land, 5 feet on water. Topography to about 150 feet. Published in Water-Supply Paper 349 .

(d) Black Creek from mouth upstream 4 miles (12NB). Plan and profile by Inited States Geological Survev, 1913. Scale, 1:31,680. Contour interval, 25 feet on land, 5 feet on water, Topography to $25-150$ feet. Published in WaterSupply Paper 349.

(c) North Fork Middle Fork Willamette River from sec. 12, T. 21 S., R. 2 E, upstream 18 miles (12NB). Plan and profile, 1913. Scale, 1:31,680. Contour interval, 25 feet on land, 5 feet on water. Topography to 25-150 feet. Published in Water-Supply Paper 349.

(c) North Fork Middle Fork Willamette River from mouth to sec. 13, T. 20 S., R. 3 E., 10 miles (12NB). Shown on two sheets, 1935 survey of Middle Fork Willamette River.

(b) Coast Fork Willamette River (12NA).

(c) Row Ráver from sec. 19, T. 21 S., R. 1 W., to sec. 29, T. 21 S., R. 1 E., 10 miles (12NA), including 2 dam sites. Plan and prefile, 1926. Scale, 1:31,680. Contour interval, 25 feet. Topography to 50-200 feet. Not published.

(b) McKenzie River from mouth to and including Clear Lake, 87 miles (12ND), including two dam sites. Plan and profile, 1925. Scale, 1:31,680. 
Contour interval, 20 feet on land, 5 feet on water. Topography to 60-200 feet. Dam-site scale, 1:4,800; contour interval, 10 feet. Published in six sheets (two plan, one plan and dam sites, three profile), 1926.

Martins Rapids dam site, in sec. 36, T. $16 \mathrm{~S} .$, R. 2 E. Topography to 150 feet.

Dam site at outlet of clear Lake, sec. 17, T. 14 S., R. 7 E. Topography to 50 feet.

(c) Lost Creek from mouth upstream 4 miles (12ND). Plan and profile, 1925. Scale, 1:31,680. Contour interval, 20 feet on land, 5 feet on water. Topography to 200 feet. Shown on 1925 survey of McKenzie River.

(c) Horse Creek from mouth upstream 10 miles (12ND). Plan and profile, 1925. Scale, 1:31,680. Contour interval, 20 feet on land, 5 on water. Topography to 200 feet. Shown on 1925 survey of McKenzie River.

(c) South Fork McKenzie River from mouth upstream 18 miles (12ND). Plan and profile, 1925. Scale, 1:31,680. Contour interval, 20 feet on land, 5 feet on water. Topography to 200 feet. Shown on 1925 survey of MeKenzie River.

(c) Blue River from mouth upstream 9 miles (12ND). Plan and profile, 1925. Scale, 1:31,680. Contour interval, 20 feet on land, 5 feet on water. Topography to 200 feet. Shown on 1925 survey of McKenzie River.

(b) Luckiamute River from Hoskins to mile 10 in sec. 20 , T. 9 S., R. 7 W. (12NF), including two dam sites. Plan and profile, 1934-35. Scale, 1:31,680. Contour interval, 20 feet on land, 5 feet on water. Topography detailed. Damsite scale, 1: 4,800; contour interval, 10 feet. Published in one sheet, 1938.

Hoskins dam site, at mile 0.0 in sec. 19 T. 10 S., R. 6 W. Topography to 150 feet.

Seekay dam site, at mile 7.2 in sec. 34, T. 9 S., R. 7 W. Topography to 180 feet.

(b) Santiam River (12NE).

(c) North Santiam River from sec. 18, T. 9 S., R. 2 E., to sec. 15, T. 11 S., R. 7 E., 47 miles (12NE). Plan and profile, 1913. Scale, 1:31,680. Contour interval, 25 feet on land, 5 feet on water. Topography to 50-150 feet. Published in Water-Supply Paper 349.

(d) North Santiam River (formerly North Fork North Fork Santiam River) from sec. 15, T. 11 S., R. 7 E., to sec. 21, T. 11 S., R. 7 E., 11/2 miles (12NE). Plan and profile, 1913. Scale, 1:31,680. Contour interval 25 feet on land, 5 feet on water. Topography to 50 feet. Published in Water-Supply Paper 349.

(d) Pamelia Creek from sec. 33, T. 10 S., R. 7 E., to sec. 36, T. 10 S., R. 7 E., 3 miles (12NE). Plan and profile, 1913. Scale, 1:31,680. Contour interval, .25 feet on land, 5 feet on water. Topography to about 500 feet. Published in Water-Supply Paper 349.

(d) Whitewater Creek from sec. 20 , T. 10 S., R. 7 E., to sec. 24 , T. S., R. 7 E., 4 miles (12NE). Plan and profile, 1913. Scale, 1:31,680. Contour interval, 25 feet on land, 5 feet on water. Topography to 50-150 feet. Published in Water-Supply Paper 349.

(d) Breitenbush River from sec. 15, T. 10 S., R. 5 E., to sec. 20, T. 9 S., R. 7 E., 14 miles (12NE). Plan and profile, 1913. Scale, 1:31,680. Contour interval, 25 feet on land, 5 feet on water. Topography to 50-150 feet. Published in Water-Supply Paper 349.

(c) South Santiam River from sec. 25, T. 13 S., R. 1 W., to mile 22, sec. 35, T. 13 S., R. 3 E. (12NE), including Middle Santiam River, and dam sites. Plan and profile, 1935. Scale, $1: 31,680$ and $1: 12,000$. Contour interval, 10 and 20 feet on land, 5 feet on water. Topography detailed. Dam-site contour interval.

$772100-48-7$ 
10 feet. Published, with survey of Middle Santiam River, in five sheets (three plan showing dam sites, one profile, one dam sites), 1938.

Sweet Home dam site, at mile 1 in sec. 25,36 , T. 13 S., R. 1 W., and sec. 30, 31, T. 13 S., R. 1 E. Scale $1: 4,80$. Topography to 180 feet.

Lower Cascadia dam site, at mile 10.1 in sec. 29 , T. 13 S., R. 2 E. Scale, 1: 2,400. Topography to 180 feet.

Upper Cascadia dam site, at mile 14.9 in sec. 35 , T. 13 S., R. 2 E. Scale, 1:2,400. Topography to 250 feet.

(d) Middle Santiam River from mouth to mile 11 in sec. 33, T. 12 S., R. 3 E. (12NE). Shown on two sheets (one plan, one profile), 1935 survey of South Santiam River and Middle Santiam River.

Green Peter dam site, at mile 6 in sec. 10, 11, T. 13 S., R. 2 E. Scale, 1: 4,800. Contour interval, 10 feet. Topography to 200 feet.

(b) Yamhill River (12NF).

(c) South Yamhill River from old Wallace Bridge, sec. 14, T. 6 S., R. 7 W., to Hanchet Creek, 17 miles (12NF). Plan and profile, 1934. Scale, 1:31,680. Contour interval, 20 feet on land, 5 feet on water. Topography detailed. Damsite scale, 1: 4,800; contour interval, 10 feet. Published in two sheets (one plan showing two dam sites, one profile), 1938.

Cedar Creek dam site, at mile 14 in sec. 33, T. 5 S., R. 8 W. Topography to 150 feet.

Wallace Bridge dam site, at mile 0.0 in sec. 14, T. 6 S., R. 7 W. Topography to 160 feet.

(d) Willamina Creek from sec. 12 , T. 5 S., R. 7 W., to point about 5 miles upstream (12NF), Willamina Creek reservoir site. Plan, 1934. Scale, 1:31,680. Contour interval, 20 feet. Topography detailed. Published in one sheet, 1937.

Willamina Creek dam site, at mile 0.0 in sec. 12, T. 5 S., R. 7 W. Scale, 1:4,800. Contour interval, 10 feet. Topography to 320 feet.

(b) Molalla River from sec. 6 to sec. 16, T. 7 S., R. 3 E., 4 miles (12NF), showing small reservoir site. Plan, 1927. Scale, 1:31,680. Contour interval, 20 feet. Topography to 300 feet. Not published.

Dam site, in sec. 6, T. 7 S., R. 3 E. Scale, 1:4,800. Contour interval, 10 feet. Topography to 300 feet. Not published.

(b) Tualatin River (12NF).

(c) Gales Creek from sec. 23 , T. 2 N., R. 5 W., to sec. 34 , T. 3 N., R. 5 W., 5 miles (12NF), showing Gales Creek reservoir site. Plan, 1934. Scale, 1:31,680. Contour interval, 20 feet. Topography detailed. Published in one sheet, 1937.

Gales Creek dam site, at mile 0.0 in sec. 23 , T. 2 N., R. 5 W. Scale, 1: 4,800. Contour interval, 10 feet. Topography to 200 feet.

(b) Clackamas River from sec. 34, T. 3 S., R. 4 E., to sec. 7, T. 7 S., R. 8 E., 41 miles (12NG). Plan and profile, 1913. Scale, 1:31,680. Contour interval, 25 feet on land, 5 feet on water. Topography to 25-150 feet. Published in WaterSupply Paper 349.

(c) Collawash River from sec. 22, T. 6 S., R. 6 E., to sec. 23 , T. 7 S., R. 6 E., 8 miles (12NG). Plan and profile, 1913. Scale 1:31,680. Contour interval, 25 feet on land, 5 feet on water. Topography to 50-150 feet. Published in WaterSupply Paper 349.

For areas in Oregon covered by United States Geological Survey standard topographic maps see plate 1.

\section{PENNSYLVANIA}

Susquenanna River from mouth to Athens, 298 miles (1PH, 1PG, 1PF, 1PE, 1PA, 1NN, 1NM, 1NL, 1NK). Profile. Scale, 1 inch $=3$ miles. Published in Water-Supply Paper $109 .^{1}$

\footnotetext{
1 Small-scale profile with table of elevation at towns and distances.
} 
(a) West Branch Susquehanna River from mouth to Keating, 105 miles (10D, 10F, 1OG, 1OH). Profile. Scale, 1 inch=14 miles. Published in Water-Supply Paper 109. ${ }^{1}$

(a) Juniata River from mouth to Hollidaysburg dam, 126 miles (1PB, 1PC, 1PD), including Frankstown Branch. Profile. Scale, 1 inch $=14$ miles. Published in Water-Supply Paper 109.

(b) Raystown Branch Juniata River from mouth to Mount Dallas, 79 miles (1 PC). Profile. Scale, 1 inch $=14$ miles. Published in Water-Supply $109 .{ }^{1}$

MISSISSIPPI RIVER.

(a) Allegheny River (head of Ohio River) from point 12 miles below Irvineton to point 2 miles above, 14 miles (3AD), reservoir site No. 3. Plan and profile, 1910. Scale, $1: 50,000$. No topography. Published in report of Flood Commission of Pittsburgh, 1911.

(a) Allegheny River from point $1 / 2$ mile below Tubbs Run to point 2 miles above Tidioute, 16 miles (3AD), reservoir site No. 2. Plan and profile, 1910. Scale 1: 50,060 . No topography. Published in report. of Flood Commission of Pittsburgh, 1911.

(b) Allegheny River from point 15 miles below Tionesta to point 1 miles above, 16 miles (3AD), reservoir site No. 1. Plan and profile, 1910. Scale, 1:50,000. No topography. Published in report of Flood Commission of Pittsburgh, 1911.

(b) Allegheny River from mouth upstream 8 miles (3AM). Plan and profile, 1909. Scale, 1:2,400. Contour interval, 2 feet. Detailed topography. Published in 7 sheets, in report of Flood Commission of Pittsburgh, 1911.

(c) Kinzua Creek from point 2.7 miles above mouth upstream 7 miles (3AB), reservoir site. Plan and profile, 1910. Scale, 1:50,000. No topography. Published in report of Flood Commission of Pittsburgh, 1911.

(c) Tionesta River from point 1.2 miles above mouth to Kellettville, 16 miles (3AD), reservoir site. Plan and protile, 1910. Scale, 1:50,000. No topography. Published in report of Flood Commission of Pittsburgh, 1911.

(c) French Creek from point 1 mile below Sugar Creek to point $4 \frac{1}{2}$ miles above Cochranton, 19 miles (3AE), reservoir site. Plan and profile, 1910. Scale, 1:50,000. No topography. Published in report of Flood Commission of Pittsburgh, 1911.

(d) North Branch French Creek from point 1.2 miles above mouth upstream 10 miles (3AE), reservoir site. Plan and profile, 1910. Scale 1:50,000. No topography. Published in report of Flood Commission of Pittsburgh, 1911.

(d) Cussawago Creek from point 2.1 miles above mouth upstream $71 / 2$ miles, disregarding bends ; actual length of meandering channel, 17 miles (3AE), reservoir site. Plan and profile, 1910. Scale, 1:50,000. No topography. Published in report of Flood Commission of Pittsburgh, 1911.

(c) East Sandy Creek from point 0.6 mile above mouth upstream $31 / 2$ miles (3AF), reservoir sites No. 1 and No. 2. Plan and profile, 1910. Scale, 1:50,000. No topography. Published in report of Flood Commission of Pittsburgh, 1911.

(c) Clarion River from point 5 miles below Millstone to Hallton, 14 miles (3AF), reservoir site No. 4. Plan and profile, 1910. Scale, 1:50,000. No topography. Published in report of Flood Commission of Pittsburgh, 1911.

(c) Clarion River from Mill Creek to point 11/2 miles above Clarington, 23 miles (3AF), reservoir site No. 3. Plan and profile, 1910. Scale, 1:50,000. No topography. Published in report of Flood Commission of Pittsburgh, 1911.

(c) Clarion River from mouth to Piney Creek, 23 miles (3AF), reservoir site No. 1. Plan and profile, 1910. Scale, 1:50,000. No topography. Published in report of Flood Commission of Pittsburgh, 1911.

(c) Red Bank Creek.

${ }^{1}$ Small-scale profile with table of elevation at towns and distances. 
(d) Little Sandy Creek from mouth upstream 7 miles (3AH), reservoir site. Plan and profile, 1910. Scale, 1:50,000. No topography. Published in report of Flood Commission of Pittsburgh, 1911.

(c) Mahoning Creek from point 1 mile below Glade Run and 51/2 miles below Milton, upstream 14 miles (3AJ), reservoir site No. 2, including 41/2 miles of Little Mahoning Creek. Plan and protile, 1910. Scale, 1:50,000. No topography. Published in report of Flood Commission of Pittsburgh, 1911.

(c) Mahoning Creek from point 11/2 miles below Putneyville to point 2 miles above Eddyville, 7 miles (3AJ), reservoir site No. 1. Plan and profile, 1910. Scale, 1:50,000. No topography. Published in report of Flood Commission of Pittsburgh, 1911.

(c) Crooked Creek from mouth upstream 14 miles (3AJ), reservoir site. Plan and profile, 1910. Scale, 1:50,000. No topography. Published in report of Flood Commission of Pittsburgh, 1911.

(c) Kiskiminetas River.

(d) Black Lick Creek from point $1 / 4$ mile above mouth upstream 101/2 miles (3AL), reservoir site. Plan and profile, 1910. Scale, 1:50,000. No topography. Published in report of Flood Commission of Pittsburgh, 1911.

(d) Loyalhanna Creek from point 1.3 miles above mouth upstream 19 miles (3AL), reservoir site. Plan and profile, 1910. Scale, 1:50,000. No topography. Published in report of Flood Commission of Pittsburgh, 1911.

(c) Buffalo Creek from point 11.7 miles above mouth upstream 6 miles (3AM), reservoir site. Plan and profile developed from United States Geological Survey maps, by Flood Commission of Pittsburgh, 1910. Scale, 1:50,000. No topography Published in report of Flood Commission of Pittsburgh, 1911.

(b) Beaver Creek from mouth to junction of Shenango and Mahoning Rivers, 25 miles (3CD). Plan and profile, 1912. Scale, 1:100,000. No contours. Published in Pymatuning reservoir report, by Water-Supply Commission of Pennsylvania, 1912.

(c) Shenango River from point near Shermansville to Turnersville, 16 miles (3CC), Pymatuning Swamp reservoir site. Plan and profile, 1912. Scale, 1: 48,000. Contour interval, 10 feet. Topography to 40 feet. Published in Pymatuning reservoir report by Water-Supply Commission of Pennsylvania, 1912.

(c) Shenango River from mouth to source, 66 miles (3CC) Plan and profile, 1912. Scale, $1: 100,000$. No contours. Published in Pymatuning reservoir report by Water-Supply Commission of Pennsylvania, 1912.

(a) Ohio River from Pittsburgh to Cairo, Ill., 967 miles. Surveyed for navigation at different dates; plan by Corps of Engineers, United States Army. Maps filed in district offices of Corps of Engineers.

(a) Ohio River at Pittsburgh, from junction of Allegheny and Monongahela Rivers downstream 5 miles (3CA). Plan and profile, 1909. Scale, 1:2,400. Contour interval, 2 feet. Detailed topography. Published in 5 sheets in report of Flood Commission of Pittsburgh, 1911.

(b) Monongahela River from mouth upstream 61/2 miles (3BH) Plan and profile, 1909. Scale, 1:2,400. Contour interval, 2 feet. Detailed topography. Published in 6 sheets in report of Flood Commission of Pittsburgh, 1911.

(c) Youghiogheny River from point 1.1 miles above confluence upstream 7 miles (3BJ), reservoir site No. 1. Plan and profile, 1910. Scale, 1:50,000. No topography. Published in report of Flood Commission of Pittsburgh, 1911.

(d) Casselman River from point 4.2 miles above mouth upstream 9 miles (3BJ), reservoir sites Nos. 1-5 Plan and profile, 1910. Scale, 1:50,000. No topography. Published in report of Flood Commission of Pittsburgh, 1911. 
(e) Laurel Hill Creek from point 5.2 miles above mouth upstream 3 miles (3BJ), reservoir site. Plan and profile, 1910. Scale, 1:50,000. No topography. Published in report of Flood Commission of Pittsburgh, 1911.

For areas in Pennsylvania covered by United States Geologieal Survey standard topographic maps see plate 1 .

\section{RHODE ISLAND}

For areas in Rhode Island covered by United States Geological Survey standard topographic maps see plate 1 .

\section{SOUTH CAROLINA}

Chattooga River (head of Savannah River). See Georgia (p. 30).

Tugaloo River (continuation of Chattooga River). See Georgia (p. 30).

(a) Chaugua Creek from mouth upstream about 9 miles (2JB). Plan by Corps of Engineers, United States Army, and United States Geological Survey, 1930. Scale, 1:24,000. Contour interval, 20 feet on land, 5 feet on river surface. Topography detailed to 700-foot contour above sea level. Shown on part of one sheet of 1929-30 survey of upper Savannah River Basin.

Savannah Rrver. See Georgia (p. 31).

(a) Seneca River from mouth to junction of Keowee River and Twelvemile Creek, about 38 miles (2JA). Plan by Corps of Engineers, United States Army, and United States Geological Survey, 1929-30. Scale, 1:24,000. Contour interval, 20 feet on land, 5 feet on river surface. Topography detailed to 625-foot contour above sea level. Shown on two sheets of 1929-30 survey of upper Savannah River Basin.

(b) Keowee River from mouth to junction of Toxaway and Whitewater Rivers, about 29 miles (2JA). Plan by Corps of Engineers, United States Army, and United States Geological Survey, 1929-30. Scale, 1:24,000. Contour interval, 20 feet on land, 5 feet on river surface. Topography detailed to 800 -foot contour above sea level. Shown on one sheet of 1929-30 survey of upper Savannah River Basin.

(c) Little River from mouth to Burnt Tanyard Bridge, about 21 miles (2JA). Plan by Corps of Engineers, United States Army, and United States Geological Survey, 1929-30. Scale, 1: 24,000. Contour interval, 20 feet on land, 5 feet on river surface. Topography detailed to 800 -foot contour above sea level. Shown on one sheet of 1929-30 survey of upper Savannah River Basin.

(b) Twelvemile Creek from mouth to Cateechee Dam, about 8 miles (2JA). Plan by Corps of Engineers, United States Army, and United States Geological Survey, 1929-30. Scale, 1:24,000. Contour interval, 20 feet on land, 5 feet on river surface. Topography detailed to 700 -foot contour above sea level. Shown on part of one sheet of 1929-30 survey of upper Savannah River Basin.

(a) Little River from mouth of Long Cane Creek to point about 0.5 mile upstream from Abbeville-McCormick County line, about 19 miles (2.JF). Plan by Corps of Engineers, United States Army, and United States Geological Survey, 1930. Scale, $1: 24,000$. Contour interval, 20 feet on land, 5 feet on river surface. Topography detailed to 380-foot contour above sea level. Shown on part of one sheet of 1929-30 survey of upper Savannah River Basin.

(b) Long Cane Creek from mouth to Curltail Branch, about 17 miles (2JF). Plan by Corps of Engineers, United States Army, and United States Geological Survey, 1930. Scale, 1:24,000. Contour interval, 20 feet on land, 5 feet on river surface. Topography detailed to 380-foot contour above sea level. Shown on part of one sheet of 1929-30 survey of upper Savannah River Basin. 
(a) Stevens Creek from point about 2 miles downstream from mouth of Turkey Creek upstream about 11 miles (2JH). Plan by Corps of Engineers, United States Army, and United States Geological Survey, 1930. Scale, 1:24,000. Contour interval, 20 feet on Iand, 5 feet on river surface. Topography detailed to 320-foot contour above sea level. Shown on part of one sheet of 1929-30 survey of upper Savannah River Basin.

(b) Turkey Creek from mouth to point about 1 mile upstream from junction with Sleepy Creek, about 22 miles (2JH). Plan by Corps of Engineers, United States Army, and United States Geological Survey, 1930. Scale, 1:24,000. Contour interval, 20 feet on land, 5 feet on river surface. Topography detailed to 320-foot contour above sea level. Shown on part of one sheet of 1929-30 survey of upper Savannah River Basin.

Catawba River. See North Carolina (p. 77).

For areas in South Carolina covered by United States Geological Survey standard topographic maps see plate 1 .

\section{SOUTH DAKOTA}

Nelson River and Lake Winnipeg, Canada.

(a) Red River from international boundary to Lake Traverse, 455 miles (50, 5P). Plan and profile by Bureau of Public Roads, United States Department of Agriculture. Scale of plan 1: 53,000; profile, $1 \mathrm{inch}=10$ miles. No topography, but many elevations are given on plan. Published in Report on drainage and prevention of overflow in the valley of the Red River of the North, United States Department of Agriculture Bulletin 1017, 1922.

Mississippi RIVER Basin (6).

(a) Missouri River from Iowa line at Sioux City to Montana-North Dakota State line, 947 miles in North Dakota and South Dakota $(6 \mathrm{E}, 6 \mathrm{JJ}, 6 \mathrm{~L})$. Surveyed for navigation; plan by Corps of Engineers, United States Army, 1892. Scale, 1:12,000. Contour interval, 20 feet. Topography varies. Complete survey includes Missouri River from mouth to Three Forks, Mont., 2,551 miles; scale, 1:63,360; no contours; topography indicated by hachures. Published in 84 sheets and 9 index sheets by Missouri River Commission, St. Louis, Mo.

(b) Little Missouri River from Montana-South Dakota Boundary to South Dakota-North Dakota Boundary ( 6 JC). Plan by United States Geological Survey and United States Bureau of Reclamation 1946-48. Scale, 1:24,000. Contour interval, 5 and 10 feet. Topography detailed. In preparation.

For areas in South Dakota covered by United States Geological Survey standard topographic maps see plate 1 .

\section{TENNESSEE}

MississipPI River Basin (3).

(a) Missouri River from Gavins Point near Yankton, South Dakota, to Stanton, North Dakota (6LN, 6LH, 6LC, 6LA, 6JW, 6JS, 6JO, 6JL). Plan by Army Map Service, Corps of Engineers, War Department, using stereophotogrammetric plotting and plane-table methods with vertical control by United States Geological Survey and United States Coast and Geodetic Survey. Aerial photography flown, 1945 ; map compiled, 1947. Scale, $1: 12,000$, also reproduced on a scale of $1: 24,000$. Contour interval, 10 feet. Topography detailed, showing wide adjacent area and closing contours on tributaries.

(a) Ohio River (3).

(b) Cumberland River (3S). 
(c) Harpeth River, 13/4 miles below Belleview (3SD), showing also proposed tunnel location to Cumberland River. Plan and profile. Scale, 1:10,560. Contour interval, 10 feet. Topography to 70 feet at dam site. Published in Tennessee Geological Survey Bulletin 30, 1923.

(b) Tennessee River. For report by Chief of Engineers, United States Army, on the Tennessee River and tributaries in North Carolina, Tennessee, Alabama, and Kentucky covering navigation, flood control, power development, and irrigation, see Seventy-first Congress, second session, House Document 328.

(c) Nolichucky River from Embreeville upstream 6 miles (3TJ). Plan and profile, 1912. Scale, 1:18,600. Contour interval, 10 feet. Topography to 50-140 feet. Published in Tennessee Geological Survey Bulletin 30, 1923.

(c) Holston River (3TC).

(d) Watauga River from Watauga to Valle Cruces, N. C., 51 miles (3TC). Plan and profile, 1902. Scale, 1:63,360. No topography. One sheet. Not published.

(e) Elk Creek from mouth to Bear Pen Falls, 12 miles (3TC). Plan and profile, 1902. Scale, 1:63,360. No topography. One sheet. Not published.

(e) Roane Creek from mouth at Butler upstream 81/2 miles (3TC). Plan and profile, 1902. Scale, 1:63,360. No topography. One sheet. Not published.

(e) Doe River from mouth to Shell Creek, 21 miles (3TC). Plan and profile, 1911. Scale, 1: 12,000. Contour interval, 5, 10, and 25 feet. Topography to 75 feet. Not published.

(c) Clinch River (3UH).

(d) Emery River (3UH).

(e) Obed River from mouth upstream 6 miles (3UH). Plan and profile, 1921. Scale, 1:31,680. Contour interval 50 feet. Topography to 100-150 feet. Published in Tennessee Geological Survey Bulletin 30, 1923.

(c) Piney River from point $3 / 4$ mile below Soak Creek upstream 2 miles (3UA). Plan and profile, 1921. Scale, 1:18,630. Contour interval, 25 feet. Topography to 75 feet at dam site. Published in Tennessee Geological Survey Bulletin 30, 1923.

(c) Hiwassee River. See Georgia (p. 34).

(c) Soddy Creek from Cincinnati, New Orleans \& Texas Pacific Railway bridge near Rathburn, upstream 3.8 miles (3VA). Plan and profile, 1921. Scale, 1: 19,800. Contour interval, 50 feet. Topography to 50-450 feet. Published in Tennessee Geological Survey Bulletin 30, 1923.

(c) Duck River (3WF).

(d) Buffalo River from Little Opossum Creek to Standing Rock Creek, 41 miles (3WF). Plan and profile, 1903. Scale, 1:23,760. Contour interval, 10 feet. Topography to 10-70 feet. Two sheets (one plan, one profile). Profile published in Water-Supply Paper 115.

(d) Buffalo River from point $3 / 4$ mile below Little Opossum Creek, near Flatwoods, upstream 2 miles (3WF), showing also proposed tunnel location. Plan. Scale, 1:37,270. Contour interval, 20 feet. Topography to 60 feet. Published in Tennessee Geological Survey Bulletin 30, 1923.

For areas in Tennessee covered by United States Geological Survey standard topographic maps see plate 1 .

\section{TEXAS}

Maps of rivers in Texas are almost entirely maps of the reservoir sites. Most of the surveys have been made by the United States Geological Survey in cooperation with the Board of Water Engineers of Texas. 
Sabrne River near Mineola, 20 miles (80). Surveyed for United States War Department; plan by United States Geological Survey and Corps of Engineers, United States Army, 1915. Sacle, 1:12,000. Contour interval, 2 feet. Topography detailed. Published in three sheets by United States Geological Survey. Out of stock.

TrinIry RIVER near Ferris, 10 miles $(8 \mathrm{~N})$. Plan by United States Geological Survey and Corps of Engineers, United States Army, 1915. Scale, 1:12,000. Contour interval, 2 feet. Topography detailed. Published in three sheets by United States Geological Survey. Out of stock.

(a) West Fork Trinity River from point about 5 miles above Newark, upstream 40 miles (8N), Fort Worth reservoir site No. 2. Plan, 1924. Scale, 1:48,000. Contour interval, 10 and 20 feet. Topography to 130 feet at dam site. Published in one sheet. Out of stock.

(a) Clear Fork Trinity River extending from Brooklyn Heights upstream 20 miles (8N), Fort Worth reservoir site. Plan, 1924. Scale, 1:24,000. Contour interval, 10 feet. Topography to 60 feet at dam site. Dam-site scale, 1: 2,400; contour interval, 5 feet. Published in two sheets (one plan, one dam site). Out of stock.

Brazos RIVER extending from latitude $32^{\circ} 22^{\prime} 30^{\prime \prime}$, longitude $97^{\circ} 38^{\prime}$, upstream 50 miles (8M), Cordova Bend reservoir site. Plan, 1923-24. Scale, 1:24,000. Contour interval, 5 and 10 feet. Topography to 70 feet at dam site. Published in one sheet. Out of stock.

Brazos RIver extending from latitude $32^{\circ} 15^{\prime}$, longitude $97^{\circ} 42^{\prime} 30^{\prime \prime}$, upstream 35 miles (8M), Rainbow reservoir site. Plan, 1924. Scale, 1:24,000. Contour interval, 10 feet. Topography to 60 feet at dam site. Published in one sheet. Out of stock.

Brazos Rrver from Rocky Creek to Nolan River, 30 miles (8M), Whitney reservoir site. Plan, 1923-24. Scale, 1:24,000. Contour interval, 5 and 10 feet. Topography to 30-60 feet. Published in one sheet. Out of stock.

Brazos River, 25 miles (8M), Breckinridge reservoir site. Plan, 1923. Scale, 1:24,000. Contour interval, 5 feet. Topography to 125 feet at dam site. Published in one sheet. Out of stock.

(a) Clear Fork Brazos River, from point about 4 miles below mouth of Ranger Creek, upstream about 7 miles $(8 M B)$, Breckinridge reservoir site. Plan, 1923. Scale, 1:24,000. Contour interval, 5 feet. Topography to 30-50 feet. Damsite scale, 1:2,400; 'contour interval, 5 feet. Published in one sheet. Out of stock.

(b) Paint Creek, 13 miles (8MB), Breckinridge reservoir site. Plan, 1923. Scale, 1:24,000. Contour interval, 5 feet. Topography to 5-100 feet. Shown on 1923 survey of Brazos River. Out of stock.

(a) Bosque River (8MC).

(b) North Fork Bosque River at Waco reservoir site, 25 miles (8MC). Plan, 1924. Scale, 1:24,000. Contour interval, 5 and 10 feet. Topography detailed. Published in one sheet. Out of stock.

(b) South Fork Bosque River at Waco reservoir site, from mouth upstream 15 miles (8MC). Plan, 1924. Scale, 1:24,000. Contour interval, 10 feet. Topography to 10-120 feet. Shown on map of Waco reservoir site. Out of stock.

(a) Little River (8MD).

(b) Leon River from point about 5 miles below mouth of Cowhouse Creek, latitude $31^{\circ} 6^{\prime}$, longitude $97^{\circ} 27^{\prime}$, upstream 40 miles ( $8 M D$ ), reservoir site. Plan, 1923-24. Scale, 1:24,000. Contour interval, 10 and 20 feet. Topography to 150 feet at dam site. Mileage is that of valley; does not follow windings or river. Published in one sheet. Out of stock. 
(b) Leon River near Belton, 15 miles (8MD), Belton reservoir site, showing short section of Lampasas River and Salado Creek. Plan, 1923-24. Scale, 1: 24,000. Contour interval, 10 and 20 feet. Topography detailed. Published in one sheet. Out of stock.

(c) Cowhouse Creek, 15 miles (8MD), Leon River reservoir site. Plan, 1923-24. Scale, 1:24,000. Contour interval, 10 and 20 feet. Topography to 10-150 feet. Shown on 1924 survey of Leon River. Out of stock.

(b) Lampasas River, 30 miles (8MD), reservoir site. Plan, 1924. Scale, 1: 24,000. Contour interval, 10 and 20 feet. Topography to 150 feet at dam site. Published in one sheet. Out of stock.

(b) Lampasas River from mouth upstream 10 miles (8MD). Plan, 1923-24. Scale, 1:24,000. Contour interval, 10 and 20 feet. Topography to 30-90 feet. Shown on 1924 survey of Leon River. Out of stock.

(c) Salado Creek from mouth upstream 5 miles (8MD). Plan, 1923-24. Scale, 1:24,000. Contour interval, 10 and 20 feet. Topography to 20-70 feet. Shown on 1924 survey of Leon River. Out of stock.

Colorado River from point near mouth of Doublebarrel Creek, latitude 31 ${ }^{\circ} 51^{\prime}$, longitude $100^{\circ} 21^{\prime}$, upstream 20 miles (8L), Bronte reservoir site. Plan, 1921. Scale, 1:24,000. Contour interval, 5 feet. Topography to 100 feet at dam site. Dam-site scale, 1:1,200; contour interval, 5 feet. Published in two sheets (one plan, one dam site). Out of stock.

(a) Concho River (8LB).

(b) Middle Concho River, 15 miles (8LB), San Angelo reservoir site. Plan, 1923-24. Scale, 1:24,000. Contour interval, 5 feet. Topography detailed. Shown on part of one sheet. Out of stock.

(c) Spring Creek, 10 miles (8LB), San Angelo reservoir site. Plan, 1923-24. Scale, 1:24,000. Contour interval, 5 feet. Topography detailed. Shown on part of one sheet. Out of stock.

(c) South Concho River, 10 miles (8LB), San Angelo reservoir site. Plan, 1923-24. Scale, 1:24,000. Contour interval, 5 feet. Topography detailed. Shown on part of one sheet. Out of stock.

(a) Pecan Bayou from point just below mouth of Jim Ned Creek upstream 15 miles (8LC), Brownwood reservoir site. Plan, 1924. Scale, 1:48,000. Contour interval, 10 and 20 feet. Topography detailed. Out of stock.

(b) Jim Ned Creek at Brownwood reservoir site, from mouth upstream 20 miles (8LC). Plan, 1924. Scale, 1: 48,000. 'Contour' interval, 10 and 20 feet. Topography detailed. Out of stock.

(a) San Saba River, from point 11/2 miles below mouth of Brady Creek, latitude $31^{\circ} 7^{\prime} 30^{\prime \prime}$, longitude $98^{\circ} 57^{\prime}$, upstream 10 miles (8LC), reservoir and dam site. Plan, 1920. Scale, 1:12,000. Contour interval, 5 feet. Topography to 100 feet at dam site. Dam-site scale, 1:1,200; contour interval, 2 feet. Published in one sheet. Out of stock.

(a) San Saba River, near San Saba, 20 miles (8LC). Plan, 1920. Scale, 1:31,680. Contour interval, 5 feet. Topography to 100 feet. Published in one sheet. Out of stock.

(b) Brady Creek from mouth upstream 5 miles (8LC), San Saba River reservoir site. Plan and profile, 1920. Scale, 1:12,000. Contour interval, 5 feet. Topography to 5-90 feet. Shown on 1920 survey of San Saba River. Out of stock.

NUEces RIver, latitude $28^{\circ} 25^{\prime}$, longitude $99^{\circ} 17^{\prime}$, upstream 30 miles ( $8 \mathrm{~KB}$ ), Cotulla reservoir site. Scale, 1:48,000. Contour interval, 10 feet. Topography detailed. Published in one sheet. Out of stock.

Misgissippi RIVER Basin (7). 
(a) Red River in Texas, opposite R. 13, 14 W., Oklahoma (7KC). Plan, 1920-21. Scale, 1:6,000. Contour interval, 2 feet. Topography detailed. Published in four sheets by Reclamation Department, State of Texas.

(b) Bois d'Arc Creek from Red River to Freemans Bridge, latitude $33^{\circ} 29^{\prime}$, longitude $96^{\circ} 12^{\prime}$ (7LA). Plan, 1914-15. Scale, 1:12,000. Contour interval, 2 feet. Topography detailed. Published in seven sheets by Reclamation Department, State of Texas.

(b) Bois d' Arc Creek from Freemans Bridge upstream to longitude $96^{\circ} 16^{\prime} \mathrm{W}$. (7LA). Plan by Reclamation Department, State of Texas. Date of survey not shown. Scale, 1:12,000. Contour interval, 2 feet. Topography detailed. One sheet. Not published.

(b) Sulphur River from point about 2 miles below mouth of Cuthand Creek, longitude $94^{\circ} 52^{\prime}$, to junction of North Fork and South Fork near boundary of Hopkins County and Franklin County (7MC). Plan by Reclamation Department, State of Texas, 1917. Scale, 1:12,000. Contour interval, 2 feet. Topography detailed. Five sheets. Not published.

(b) Sulphur River from longitude $94^{\circ} 45^{\prime}$ upstream 17 miles (7MC). Plan, 1928. Scale, 1:48,000. Contour interval, 5 feet. Topography detailed. Published in one sheet by United States Geological Survey and Reclamation Department, State of Texas.

(c) South Sulphur River from junction of North Fork and South Fork near corner common to Hopkins, Franklin, Lamar, and Red River Counties, upstream to point about 1 mile above Hunt-Delta County boundary (7MC). Plan by Reclamation Department, State of Texas, 1925. Scale, 1:12,C00. Contour interval, 2 feet. Topography detailed. Seven sheets. Not published.

(c) North Sulphur River from junction of North Fork and Sonth Fork near corner common to Hopkins, Franklin, Lamar, and Red River counties, upstream to Allen Creek, longitude $96^{\circ} 4^{\prime}$ (7MC). Plan by Reclamation Department, Stateof Texas, 1917, 1918, 1923, 1924, 1927, and 1928. Scale, 1:12,000. Contour interval, 2 feet. Topography detailed. Seven sheets. Not published.

(d) Middle Sulphur River from junction with South Surphur River to point 2 miles above Hunt-Delta County line (7MC). Plan by Reclamation Department, State of Texas, 1924-25. Scale, 1:12,000. Contour interval, 2 feet. Topography detailed. Two sheets. Not published.

(c) Cuthand Creek from mouth upstream to longitude $95^{\circ} 3^{\prime}$ (7MC). Plan by Reclamation Department, State of Texas, 1922. Scale, 1:12,000. Contour interval, 2 feet. Topography detailed. Three sheets. Not published.

For areas in Texas covered by United States Geological Survey standard topographic maps see plate 1 .

\section{UTAH}

Great Saxt Lake Basin (10H).

(a) Jordan River (10HH).

(b) Utah Lake Basin (10HF).

(c) Salt Creek from sec. 1, T. 13 S., R. 1 E., to sec. 28 , T. 12 S., R. 2 E., 5 miles (10HF). Plan and profile, 1920. Scale, 1:13,680. Contour interval, 25 feet. Topography to 400 feet. Shown on parts of two sheets.

(c) Santaquin Creek from sec. 13, T. 10 S., R. 1 E., to sec. 33, T. 10 S., R. 2 E., 5 miles (1HF). Plan and profile, 1920. Scale, 1:31,680. Oontour interval, 25 feet. Topography to $100-400$ feet. Shown on parts of two sheets.

(o) Payson Creek from sec. 16, T. 9 S., R. 2 E., to sec. 10, T. 10 S., R. 2 E., 6 miles (10HF). Plan and profile, 1920. Scale, 1:31,680. Contour interval, 25 feet. Topography to $100-400$ feet. Shown on parts of two sheets.

(c) Spanish Fork (10HF). 
(d) Diamond Creek from mouth in sec. 17, T. 9 S., R. 4 E., to sec. 36 , T. 7 S., R. 5 E., 17 miles (10HF). Plan and profile by United States Geological Survey and United States Bureau of Reclamation, 1920. Scale, 1:31,680. Contour interval, 25 feet. Topography to $100-400$ feet. Published in three sheets (plan on parts of two sheets, profile on one sheet), by United States Geological Survey.

(e) Sixth Water Creek from mouth in sec. 27 , T. 8 S., R. 5 E., to sec. 34 , T. 7 S., R. $6 \mathrm{E}$., 10 miles $(10 \mathrm{HF})$. Plan and profile by United States Geological Survey and United States Bureau of Reclamation, 1920. Scale, 1:31,680. Contour interval, 25 feet. Topography to $100-400$ feet. Published on parts of two sheets, by United States Geological Survey.

(c) Hobble Creek from Springville in sec. 33, T. 7 S., R. 3 E., to sec. 33, T. 7 S., R. 4 E., 7 miles (10HF). Plan and profile, 1920. Scale, 1:31,680. Contour interval, 25 feet. Topography to 25-300 feet. Published on parts of two sheets.

(c) American Fork from sec. 36, T. 4 S., R. 1 E., to 9,500-foot contour, 17 miles (10HF). Plan and profile, 1920. Scale, 1:31,680. Contour interval, 25 feet. Topography to 400 feet. Published on parts of two sheets.

(d) South Fork American Fork from mouth upstream 1 mile (10HF). Plan and profile, 1920. Scale, 1:31,680. Contour interval, 25 feet. Topography to 400 feet. Published on part of one sheet.

(c) Provo River from sec. 36, T. 3 S., R. 4 E., to sec. 1, T. 3 S., R. 7 E., 30 miles (10HG). Plan and profile, 1920. Scale, 1:31,680. Contour interval, 25 feet. Topography to $200-400$ feet. Published in three sheets (two plan, one profile).

(c) Provo River about 11 miles above city of Heber, in sec. 26, T. 2 S., R. 5 E. (10HG). Bates reservoir site. Plan by Utah Water Storage Association, 1919. Scale, 1: 2,640. Contour interval, 10 feet. Topography to 120 feet at dam site. Published in Water-Supply Paper 517.

(c) Provo River from sec. 7, T. 5 S., R. 4 E., to sec. 15, T. 4 S., R. 4 E., 7 miles (10HG). Plan and profile, 1920. Scale, 1:31,680. Contour interval, 25 feet. Topography to 100 feet. Shown on parts of two sheets.

(o)' Provo River from sec. 7, T. 5 S., R. 4 E., to sec. 15, T. 4 S., R. 4 E., 7 miles (10HG), Deer Creek reservoir site. Plan by Utah Water Storage Association, 1919. Scale, 1:48,000. Contour interval, 25 feet. Topography to 110 feet at dam site. Published in Water-Supply Paper 517.

(d) North Fork Provo River from mouth in sec. 24, T. 5 S., R. 3 E., to sec. 10, T. 5 S., R. 3 E., 4 miles (10HG). Plan and profile by United States Geological Survey and United States Bureau of Reclamation, 1920. Scale, 1:31,680. Contour interval, 25 feet. Topography to $400-700$ feet. Shown on part of one sheet, 1920 survey of Provo River, published by United States Geological Survey.

(e) South Fork North Fork Provo River froin mouth in sec. 11, T. 5 S., R. 3 E., to east boundary of Wasatch National Forest, 1 mile (10HG). Plan, 1920. Scale, $1: 31,680$. Contour interval, 25 feet. Topography to 25-500 feet. Shown on part of one sheet, 1920 survey of Provo River.

(d) Round Valley Creek from mouth in sec. 4, T. 5 S., R. 4 E., to sec. 3, T. 5 S., R. 4 E., 2 miles (10HG). Plan, 1920. Scale, 1:31,680. Contour interval, 25 feet. Topography to 150 feet. Shown on one sheet, 1920 survey of Provo River.

(b) Little Cottonwood Creek from sec. 34, T. 2 S., R. 1 E., to Alta, 8,700-foot contour, 2 miles $(10 \mathrm{HH})$. Plan and profile, 1920. Scale, 1:31,680. Contour interval, 25 feet. Topography to 500-1,000 feet. Published in two sheets (one plan, one profile), in 1922.

(c) South Mahogany Fork Little Cottonwood Creek from mouth to 8,800-foot contour, 2 miles $(10 \mathrm{HH})$. Plan and profile, 1920. Scale, 1:31,680. Contour interval, 25 feet. Topography to 500 feet. Shown on one sheet, 1920 survey of Little Cottonwood Creek. 
(a) Cottonwood Creek from sec. 15, T. 2 S., R. 1 E., to sec. 21, T. 2 S., R. 3 E., 14 miles $(10 \mathrm{HH})$. Plan and profile, 1920. Scale, 1:31,680. Contour interval, 25 feet. Topography to $400-600$ feet. Published in two sheets (one plan, one profile), 1922.

(b) Mill B South Fork from mouth upstream 1 mile (10HH). Plan and profile, 1920. Scale, 1:31,680. Contour interval, 25 feet. Topography to 600 feet. Shown on 1920 survey of Cottonwood Creek.

(a) Mill Creek from sec. 36, T. 1 S., R. 1 E., to sec. 32, T. 1 S., R. 3 E., 9 miles $(10 \mathrm{HH})$. Plan and profile, 1920. Scale, 1:31,680. Contour interval, 25! feet. Topography to 400-800 feet. Shown on one sheet, 1920 survey of Little Cottonwood Creek.

(a) Weber River, from Echo City in sec. 24 , T. 3 N., R. 4 E., to Coalville, 5 miles (10HE), Echo reservoir site. Plan by Utah Water Storage Association, 1919. Scale, 1:42,240. Contour interval, 10 feet. Topography to 100 feet at dam site. Published in Water-Supply Paper 517.

(a) Weber River from sec. 17, T. 1 N., R. 5 E., to sec. 26, T. 1 N., R. 8 E., 31 miles (10HE). Plan and profile, 1920. Scale, 1:31,680. Contour interval, 25 feet. Topography to $25-400$ feet. Published in five sheets (three plan, two profile), 1922.

(a) Weber River from sec. 30, T. 3 N., R. 5 E., to sec. 8, T. 2 N., R. 5 E., 4 miles (10HE). Plan and profile, 1920. Scale, 1:31,680. Contour interval, 25 feet. Topography to 25-400 feet. Published as part of 1920 survey of Weber River from sec. 17.

(b) Smith and Morehouse Creek from mouth in sec. 28 , T. 1 N., R. 7 E., to sec. 12, T. 1 S., R. 7 E., 6. miles (10HE). Plan and profile, 1920. Scale, 1:31,680. Contour interval, 25 feet. Topography to 400 feet. Shown on two sheets, 1920 survey of Weber River.

(b) South Fork Weber River from mouth in sec. 12, T. 1 S., R. 6 E., to sec. 8, T. 1 S., R. 6 E., 2 miles (10HE). Plan, 1920. Scale, $1: 31,680$. Contour interval, 25 feet. Topography to 300 feet. Shown on one sheet, 1920 survey of Weber River.

(b) Beaver Creek from mouth in sec. 26, T. 1 S., R. 5 E., to sec. 25, T. 2 S., R. 6 E., 11 miles (10HE). Plan and profile, 1920. Scale, 1:31,680. Contour intervals, 25 feet. Topography to 200 feet. Shown on parts of two sheets (one plan, one profile), 1920 survey of Weber River.

(b) Beaver Creek in sec. 25, 36, T. 1 S., R. 5 E., sec. 1, T. 2 S., R. 5 E., and sec. 6, T. 2 S., R. 6 E. (10HE), Beaver Creek reservoir site. Plan by Utah Water Storage Association, 1919. Scale, 1:24,000. Contour interval, 5 feet. Topography to 55 feet at dam site. Published in Water-Supply Paper 517.

(b) Chalk Creek from mouth in sec. 8, T. 2 N., R. 5 E., to sec. 26, T. 3 N., R. $6 \mathrm{E} ., 12$ miles $(10 \mathrm{HE})$. Plan and profile, 1920. Scale, 1:31,680. Contour interval, 25 feet. Topography to 300 feet. Published on parts of two sheets, 1920 survey of Weber River.

(b) Lost Creek in sec. 4, 5, 8, T. 5 N., R. 5 E., 11/2 miles (10HE), Lost Creek reservoir site. Plan by Utah Water Storage Association, 1920. Scale, 1:15,840. Contour interval, 10 feet. Topography to 100 feet at dam site. Published in Water-Supply Paper 517.

(c) South Fork Chalk Creek from mouth in sec. 5, T. 2 N., R. 6 E., to sec. 10 T. 2 N., R. 6 E., 2 miles (10HE). Plan, 1920. Scale, 1:31,680. Contour interval, 25 feet. Topography to 200 feet. Published on parts of two sheets, 1920 survey of Weber River.

(b) East Canyon Creek from mouth in sec. 27, T. 4 N., R. 2 E., to sec. 23, T. 2 N., R. 3 E., 18 miles (10HE). Plan and profile, 1920. Scale, 1:31,680. 
Contour interval, 25 feet. Topography to 25-200 feet. Published in two sheets (one plane, one profile), 1920 survey of Weber River.

(b) Ogden River from east line of sec. 12, T. 6 N., R. 2 E., to sec. 33, T. 7 N., R. 3 E., 3 miles (10HE), Magpie and Cobble Creek reservoir sites. Plan by City Engineering Department of Ogden, 1908. Scale, 1:18,000. Contour interval, 20 feet. Topography to 160 feet. Published in Water-Supply Paper 517.

(c) Righthand Fork in sec. 34, 35, 36, T. 7 N., R. 3 E., and sec. 1, 2, 3, T. 6 N., R. 3 E., 11/2 miles (10HE), reservoir site. Plan by City Engineering Department of Ogden, 1908. Scale, $1: 18,000$. Contour interval, 20 feet. Topography to 180 feet at dam site. Published in Water-Supply Paper 517.

(a) Willard Creek from Willard to sec. 32 , T. 8 N., R. 1 W., about 5 miles (10HA). Plan by United States Geological Survey in cooperation with United States Forest Service, 1936. Scale, 1:12,000. Contour interval, 10 feet. Topography detailed. Published in one sheet by United States Geological Survey, 1937.

(a) Bear River, Utah and Wyoming, from point 6 miles north of Cokeville, Wyo., to junction of Stillwater Fork, Utah; total channel length 178 miles, of which mile 0 to mile 41 , and mile 101 to mile 168, is in Wyoming, the remaining 70 miles in Utah, (10HB), showing dam sites. Surveyed, 1934-38. Scale, 1: 31,680. Contour interval, 10 and 20 feet on land, 5 feet on water. Wide area of adjacent topography. Published in 13 sheets, 10 plan, 3 showing large-scale surveys of dam sites, 1941.

(b) Stillwater Fork to mile 7 (10HB). Shown on 1934-38 survey of Bear River.

Stillwater dam site, at mile 3.4 in sec. 10 , T. 1 N., R. 10 E. Scale, $1: 4,800$. Contour interval, 10 feet. Topography to 250 feet.

(b) East Fork Bear River to mile 10 (10HB). Shown on 1934-38 survey of Bear River.

East Fork dam site, at mile 4.0 in sec. 26 , T. 2 N., R. 10 E. Scale, 1:4,800. Contour interval, 10 feet. Topography to 270 feet.

(b) Yellow Creek, Utah and Wyoming, from mouth to mile 24 (10HB), of which approximately 5 miles (mile 13 to mile 18) is in Utah. Shown on 1934-38 survey of Bear River.

Yellow Creek dam site, at mile 16.9 in sec. 32, 33, T. 5 N., R. 8 E., Utah. Scale, 1:4,800. Contour interval, 10 feet. Topography to 300 feet.

(b) Saleratus Creek to mile 14 (10HB). Shown on 1934-38 survey of Bear River.

(b) Logan River from sec. 36, T. 12 N., R. 1 E., to Tony Grove Creek, 22 miles (10HC). Plan and profile, 1914. Scale, 1:48,000. Contour interval, 25 feet. Topography to $300-400$ feet. Published in Water-Supply Paper 420 .

(o) Blacksmith Fork from sec. 2, T. 10 N., R. 1 E., to sec. 14, T. 10 N., R. 3 E., 15 miles $(10 \mathrm{HC})$. Plan and profile by United States Geological Survey, 1914. Scale, 1:48,000. Contour interval, 25 feet. 'Topography to $300-400$ feet. Published in Water-Supply Paper 420 .

Sevier Lake Basin (10J).

(a) Sevier River from Piute dam, sec. 3, T. 29 S., R. 3 W., upstream to sec. 23 , T. 38 S., R. 6 W., 91 miles (10JA, 10JC), including East Fork. Plan, 1935-37. Scale, 1:31,680 for most of course: 1:24,000 for lower course showing Piute Reservoir area. Contour interval, 10 and 20 feet on land, 5 feet on water. Wide area of adjacent topography. Published in seven sheets, 1939.

(b) Asay Creek to mile 9 (10JA). Scale, 1:31,680. Shown on one sheet of 1935-37 survey of Sevier River.

(b) East Fork Sevier River from mouth to Podunk Creek, 91 miles (10JB). Scale; $1: 31,680$. Contour interval, 10 and 20 feet on land, 5 and 20 feet on water. Shown on 1935-37 survey of Sevier River. 
(c) Otter Creek from junction with East Fork Sevier River to sec. 25, T. 29 S., R. 2 W., 7 miles (10JB), showing Otter Creek reservoir. Scale, 1:24,000. Contour interval, 10 feet on land, 5 feet on water. Shown on one sheet, 1935-37 survey of Sevier River.

(b) San Pitch River (10JD).

(c) Cottonwood Creek from mouth to sec. 24, T. 13 S., R. 5 E., 8 miles (10JD). Plan and profile, 1933. Scale, 1:31,680. Contour interval, 20 feet. Topography detailed. Published, with map of Pleasant Creek, in two sheets (one plan, one profile), 1937.

(c) Pleasant Creek from mouth to sec. 10, T. 15 S., R. 5 E., 9 miles (10JD), showing also parts of Coal Fork, Straight Fork, and North Fork. Plan and profile, 1933. Scale, $1: 31,680$. Contour interval, 20 feet. Topography detailed. Published, with map of Cottonwood Creek, in two sheets (one plan, one profile), 1937.

(c) Ephraim Creek from point 2 miles below Ephraim, sec. 32, T. 16 S., R. 3 E., upstream 8 miles to sec. 17, T. 17 S., R. 4 E. (10JD). Plan and profile, 1933-34. Scale, $1: 31,680$. Contour interval, 20 feet. Topography detailed. Published in one sheet, 1937.

(c) Manti Creek from mouth to sec. 4, T. 18 S., R. 4 E., 9 miles (10JD), including North Fork. Plan and profile, 1934. Scale, 1:31,680. Contour interval, 20 feet. Topography detailed. Published in one sheet, 1937.

Colorado River from canyon below Moab, Utah to Mack, Colo., 69 miles in Utah and 16 in Colo. (9DN). This includes the Dewey reservoir site. Plan and profile by United States Geological Survey and Bureau of Reclamation in 1941, and 1943-45. Scale, $1: 24,000$. Contour interval, 20 feet on land, 5 feet on water. Topography to 300 feet. Published in 14 sheets (11 plan, 3 profile), 1948.

Colorado River just below mouth of Dolores River (9DM) Dewey dam site. Plan and four cross sections by United States Bureau of Reclamation. Scale, $1: 13,333$ ( 0.9 inch=1,000 feet). Contour interval, 25 feet. Published in Senate report, Problems of Imperial Valley and Vicinity, Sixty-seventh Congress, second session, Senate Document 142.

CoLorado RIver from mouth of Green River to Grand Junction, Colo., 133 miles in Utah, 40 miles in Colorado (9DM). Plan and profile, 1912. Scale, 1:31,680. Contour interval, 25 feet on land, 5 feet on water. Topography to 200-1,200 feet. Published in Water-Supply Paper 396.

Colorado RIver from Lees Ferry, Ariz., to mouth of Green River, 188 miles in Utah, 28 miles in Arizona (9FA, 9FC, 9FE). Plan and profile by United States Geological Survey in cooperation with Southern California Edison Co., 1921. Scale, $1: 31,680$. Contour interval, 20 feet on land, 5 feet on water. Topography to $400-800$ feet. Published in 16 sheets ( 12 plan, 4 profile) by United States Geological Survey. Complete survey includes plans of the following streams:

(a) Fremont River from mouth to 3,901-foot contour, 30 miles (9FB).

(a) Trachyte Creek from mouth to 3,900-foot contour, 6 miles (9FC).

(a) Twomile Creek from mouth to 3,900-foot contour, 2 miles (9FC).

(a) Fourmile Creek from mouth to 3,900-foot contour, 3 miles (9FC).

(a) Sevenmile Creek from mouth to 3,900 foot contour, 3 miles $(9 \mathrm{FC}$ ).

(a) Smith Fork from mouth to 3,900-foot contour, 4 miles (9FC).

(a) Hansen Creek from mouth to 3,900-foot contour, 8 miles (9FC).

(a) Moki Creek from mouth to 3,900-foot contour, 8 miles (9FO).

(a) Bullfrog Creek from mouth to 3,900-foot contour, 18 miles (9FC).

(a) Halls Creek from mouth to 3,900-foot contour, 15 miles (9FC).

(a) Escalante River from mouth to 3,900-foot contour, 30 miles (9FD).

(a) Aztec Creek from mouth to 3,900-foot contour, 6 miles (9FE). 
(a) Rock Creek from mouth to 3,900-foot contour, 9 miles (9FE).

(a) West Canyon Creek from mouth to 3,900-foot contour, 8 miles (9FE).

(a) Last Chance Creek from mouth to 3,900-foot contour, 15 miles (9FE).

(a) Kane Creek from mouth to 3,900-foot contour, 4 miles (9FE).

(a) Warm Creek from mouth near southeast corner of sec. 1, T. 44 S., R. 4 E., to 3,900-foot contou'r, 16 miles (9FE).

(a) Wahweap Creek from mouth in Arizona to sec. 11, T. 43 S., R. 2 E., 15 miles (9FE).

(a) Dolores River from mouth to Utah-Colorado State line, 22 miles (9DK), Plan and profile, 1924. Scale, 1:31,680. Contour interval, 50 feet. Topography to 350-800 feet. Part of plan and profile of river from mouth in Utah to Paradox Valley in Colorado. Two sheets. Not published.

(a) Dolores River from mouth to point near Colorado-Utah State line, 22 miles (9DK), showing area within Dewey reservoir site. Plan and profile by United States Geological Survey and United States Bureau of Reclamation, 1941-45. Scale, 1:24,000. Contour interval, 20 feet on land, 5 feet on water. Plan on sheets 4 and 10, profile on sheet 14, 1941-45 survey of Colorado River.

(a) Green River from Green River, Utah, in sec. 15, T. $21 \mathrm{~S}$, R. $16 \mathrm{E}$, to Green River, Wyo., 279 miles in Utah, 65 miles in Wyoming, 42 miles in Colorado (9AK, 9BA, 9BJ). Plan and profile by United States Bureau of Reclamation and United States Geological Survey in cooperation with Utah Power \& Light Co., 1904, 1913-14, 1918, 1922. Scale, 1:31,680. Contour interval, 20 feet on land, 5 feet on water. Topography to $20-400$ feet. Published in 16 sheets (10 flan, 6 profile), by United States Geological Survey, 1924.

(a) Green River, Flaming Gorge dam site, about mile 313.5 above Green River, Utah, (9AK). Plan and two cross sections by United States Bureau of Reclamation. Scale, $1: 3,430$ (1.4 inches $=400$ feet), and $1: 13,600$ (1.06 inches $=1,200$ feet). Contour interval, 10 and 50 feet. Published in report, Problems of Imperial Valley and vicinity, by Sixty-seventh Congress, second session, Senate Document 142.

(a) Green River from Colorado-Utah State line to sec. 7, T. 6 S., R. 22 E., 46 miles (12BA). Plan and profile, 1909. Scale, 1:31,680. Topography not shown. Published in Water-Supply Paper 396.

(a) Green River from sec. 7, T. 6 S., R. 22 E., to sec. 32 , T. 9 S., R. 19 E., 54 miles (9BA, 9BJ). Plan and profile, 1913-14. Scale, 1:31,680. Contour interval, 25 feet on land, 5 feet on water. Little topography. Published in Water-Supply Paper 396.

(a) Green River from mouth to Gunnison Butte, about sec. 10, T. 20 S., R. 16 E., 128 miles (9BL, 9BJ). Plan and profile by United States Bureau of Reclamation, 1914. Scale, 1:31,680. Contour interval, 25 feet. Topography to 100200 feet. Published in Water-Supply Paper 396.

(b) Ashley Creek from south line of sec. 12, T. 3 S., R. 20 E., upstream 111/2 miles (9BA). Plan and profile, 1923-24. Scale, 1:31,680. Contour interval, 20 and 50 feet. Topography to $200-1,300$ feet. Shown on parts of 2 sheets, Duchesne River and tributaries 1925.

(c) Dry Fork from east line of sec. 16, T. 3 S., R. 20 E., upstream 15 miles (9BA). Plan and profile, 1923-24. Scale, 1:31,680. Contour interval, 20 and 100 feet. Topography to $80-800$ feet. Shown on parts of two sheets, Duchesne River and tributaries 1925.

(b) Duchesne River from mouth in sec. 32, T. 4 S., R. 3 E., to sec. 28 , T. 3 S., R. 1 W., 41 miles (9BD). Plan and profile, 1913-14. Scale, 1:48,000. Contour interval, 25 feet on land, 5 feet on water. Very little topography. Published in Water-Supply Paper 396. 
(b) Duchesne River from NE1/4 sec. 30 , T. 1 N., R. 8 W., to sec. 14 , T. 3 N., R.' 9 W., 15 miles (9BB). Plan and profile, 1923-24. Scale, 1:31,680. Contour interval, 20 feet. Topography to 200-1,100 feet. Shown on parts of two sheets, Duchesne River and tributaries 1925.

(b) Duchesne River.

Dam site A, just below mouth of Hades Creek, surveyed 1924. Scale, 1:3,168. Contour interval, 5 feet. Topography to 120 feet. Shown on part of one sheet, Duchesne River and tributaries 1925.

(c) Hades Creek from mouth in sec. 26, T. 2 N., R. 9 W., upstream 41/2 miles (9BB). Plan and profile, 1923-24. Scale, 1:31,680. Contour interval, 20 feet. Topography to 100-1,100 feet. Shown on parts of two sheets, Duchesne River and tributaries 1925.

(c) West Fork Duchesne River from mouth in sec. 19, T. 1 N., R. 8 W., to sec. 30, T. 1 N., R. 9 W., 61/2 miles (9BB). Plan and profile, 1923-24. Scale, 1: 31,680. Contour interval, 20 feet. Topography to 200-500 feet. Shown on parts of two sheets, Duchesne River and tributaries 1925.

(d) Wolf Creek from mouth in sec. 26, T. 1 N., R. 9 W., upstream 2 miles (9BB). Plan and profile 1923-24. Scale, 1:31,680. Contour interval, 20 feet. Topography to 200-300 feet. Shown on parts of two sheets, Duchesne River and tributaries 1925.

(c) Rock Creek from south line of sec. 9, T. 1 N., R. 6 W., to sec. 8, T. 3 N., R. $7 \mathrm{~W}$., 161/2 miles (9BB). Plan and profile, 1923-24. Scale, 1:31,680. Contour interval, 20 feet. Topography to $200-300$ feet. Shown on parts of two sheets, one showing dam site, Duchesne River and tributaries 1925.

Dam site B, in sec. 9, T. 1 N., R. $6 \mathrm{~W}$. Scale, $1: 3,168$. Contour interval, 5 feet. Topography to 150 feet.

(d) West Fork Rock Creek from mouth in sec. 5, T. 2 N., R. 7 W., upstream 21/2 miles (9BB). Plan and profile, 1923-24. Scale, 1:31,680. Contour interval, 20 and 100 feet. Topography to 100-600 feet. Shown on parts of two sheets, Duchesne River and tributaries 1925.

(c) Strawberry River, T. 3, 4 S., R. 5, 6 W. (9BB), Starvation reservoir site. Plan by United States Bureau of Reclamation, 1920. Scale, 1:6,000. Contourinterval, 10 feet. Topography to 150 feet. Not published.

(c) Strawberry River from sec. 14, T. 4 S., R. 8 W., to sec. 17, T. 4 S., R. 7 W. (9BB), Three Forks reservoir site. Plan by United States Bureau of Reclamation, 1920. Scale, $1: 6,000$. Contour interval, 10 feet. Not published.

(d) Lower Current Creek from sec. 27 , T. 3 S., R. 9 W., to sec. 30, T. 3 S., R. 8 W. (9BB), reservoir site. Plan by United States Bureau of Reclamation, 1920. Scale, 1:6,000. Contour interval, 10 feet. Not published.

(c) West Fork Lake Fork (head of Lake Fork) from forks in sec. 32, T. 1 N., R. 4 W., to sec. 9, T. 3 N., R. 6 W., 201/2 miles (9BC). Plan and profile, 1923-24. Scale, $1: 31,680$. Contour interval, 20 feet. Topography to $60-700$ feet. Shown. on parts of two sheets, Duchesne River and tributaries 1925.

(d) Spring Branch from mouth in sec. 13, T. 2 N., R. 6 W., to sec. 11, T. 2 N., R. 6 W., 2 miles (9BC). Plan and profile, 1923-24. Scale, 1:31,680. Contourinterval, 20 feet. Topography to 20-700 feet. Shown on parts of two sheets, Duchesne River and tributaries 1925.

(d) East Fork Lake Fork from forks in sec. 32, T. 1 N., R. 4 W., to sec. 10, T. 3 N., R. 5 W., 20 miles (9BC). Plan and profile, 1923-24. Scale, 1:31,680. Contour interval, 20 feet. Topography to $100-300$ feet. Shown on parts of two. sheets, Duchesne River and tributaries 1925.

(e) Swift Creek from mouth in sec. 4 , T. 2 N., R. 4 W., to sec. 33, T. 3 N., R. $4 \mathrm{~W} ., 11 / 2$ miles (9BC). Plan and profile, 1923-24. Scale, 1:31,680. Contour- 
interval, 100 feet. Topography to 20-600 feet. Shown on parts of two sheets, Duchesne River and tributaries 1925.

(c) Uinta River from mouth in sec. 17, T. 3 S., R. 2 E., to sec. 20 , T. 1 S., R. 1 E., 22 miles (9BE). Plan and profile, 1913-14. Scale, 1:48,000. Contour interval, 25 feet on land, 5 feet on water. Very little topography. Published in Water-Supply Paper 396.

(c) Uinta River from east line of sec. 5 , T. 1 N., R. 1 W., to north line of sec. 26, T. 4 N., R. 3 W. 20 miles (9BE). Plan and profile, 1923-24. Scale, 1:31,680. Contour interval, 100 feet on land, 20 feet on water. Topography to $20-400$ feet. Shown on parts of two sheets, Duchesne River and tributaries 1925.

(d) Pole Creek from mouth to north line of sec. 23, T. 2 N., R. 2 W., $2 \frac{1}{2}$ miles (9BE). Plan, 1923-24. Scale, 1:31,680. Contour interval, 20 feet. Topography to 20-100 feet. Shown on part of one sheet, Duchesne River and tributaries 1925.

(d) Whiterocks Creek from south line of sec. 19, T. 2 N., R. 1 E., to sec. 13, T. 4 N., R. 1 W., 13 miles (9BE). Plan and profile, 1923-24. Scale, 1:31,680. Contour interval, 100 feet. Topography to $200-600$ feet. Shown on parts of 2 sheets, Duchesne River and tributaries 1925.

(d) Deep Creek (9BE).

(e) Mosby Creek from point near south line of sec. 6, T. 3 S., R. 19 E., upstream 2 miles (9BE). Plan and profile, 1923-24. Scale, 1:31,630 Contour interval, 20 feet. Topography detailed on west side; very little on east side. Shown on parts of two sheets, Duchesne River and tributaries 1925.

(b) White River from mouth in sec. 4 , T. 9 S., R. 20 E., to sec. 1, T. 9 S., R. 1 E., 17 miles $(9 \mathrm{BH})$. Plan and profile, 1913-14. Scale, $1: 48,000$. Contour interval, 25 feet on land, 5 feet on water. Very little topography. Published in WaterSupply Paper 396.

(b) San Rafael River from mouth to Castle Dale in sec. 33, T. 18 S., R. 8 E., 121 miles (9BK). Plan and profile, 1925. Scale, 1:31,680. Contour interval, 25 feet on land, 5 feet on water. Topography detailed. Published in four sheets (two plan, two profile), 1926.

(b) San Rafael River from mouth in sec. 25, T. 23 S., R. 16 E., to sec. 4, T. 24 S., R. 16 E., 4 miles (9BK). Plan, 1914. Scale, 1: 31,680. Contour interval, 25 feet. Topography to 150 feet. Published in Water-Supply Paper 396 as part of 1913-14 survey of Green River from mouth to Gunnison Butte.

(c) Huntington Creek from Huntington, sec. 19, T. 17 S., R. 9 E., to sec. 30, T. 14 S., R. 7 E., 27 miles (9BK), showing dam site. Plan and profile, 1933. Scale, 1:31,680. Contour interval, 20 feet on land, 5 feet on water Topography detailed. Published in three sheets (one plan, one profile, and one showing Brockbank dam site), 1937.

Brockbank dam site, at mile 5.5 in sec. 9, T. 17 S., R. 8 E. Scale, $1: 2,400$. Contour interval, 10 feet. Topography to 110 feet.

(c) Buckhorn Wash from San Rafael River upstream 3 miles (9BK). Plan and profile, 1925. Scale, 1:31,680. Contour interval, 25 feet on land, 5 feet on water. Topography detailed. Shown on two sheets, 1925 survey of San Rafael River.

(a) San Juan River from sec. 36, T. 40 S., R. 23 E., to Colorado State line, 29 miles (9GH). Plan, 1939. Scale, 1:31,680. Contour interval, 20 feet on land, 5 feet on water. Topography detailed. In preparation.

(a) San Juan River from Chinle Creek to sec. 36, T. 40 S., R. 23 E., 24 miles (9GH). Plan by United States Bureau of Reclamation, 1914. Scale, 1:31,680. Contour interval, 50 feet. Topography generalized on assumed datum. In preparation for publication in one set with surveys on San Juan River by United States Geological Survey.

$772100-48-8$ 
(a) San Juan River from mouth to Chinle Creek, 133 miles (9GH). Plan and profile by United States Geological Survey in cooperation with Southern California Edison Company, 1921. Topography to 200-600 feet. Published in 5 sheets ( 3 plan, 2 profile), 1921 survey of Colorado River from Lees Ferry, Ariz., to mouth of Green River, by United States Geological Survey, 1922.

(b) Butler Wash from mouth upstream 3.5 miles (9GH). Shown on 1914 surrey of San Juan River by United States Bureau of Reclamation. In preparation.

(b) Comb Wash from mouth upstream 6 miles (9GH). Shown on 1914 survey of San Juan River by United States Bureau of Reclamation. In preparation.

(b) Cottonwood Wash from mouth upstream 5 miles (9GH). Shown on 1914 survey of San Juan River by United States Bureau of Reclamation. In preparation.

(b) Piute Creek from mouth to 3,900-foot contour, 6 miles (9GH). Shown on 1921 survey of Colorado River from Lees Ferry, Ariz., to mouth of Green River, published by United States Geological Survey, 1922.

(b) Wilson Creek from mouth to 3,900-foot contour, 2 miles (9GH). Shown on 1921 survey of Colorado River from Lees Ferry, Ariz., to mouth of Green River, published by United States Geological Survey, 1922.

For area in Utah covered by United States Geological Survey standard topographic maps see plate 1 .

\section{VERMONT}

St. Lawrence River Basin (4P).

(a) Lake Champlain (4PG).

(b) Winooski River from Richmond to line between Cabot and Marshfield Townships, 51 miles (4PG). Plan by United States Geological Survey in cooperation with State of Vermont, 1910. Scale, 1:24,000. Contour interval, 10 feet on land, 1 foot on water. Topography to about 20 feet. Includes plans of the following ponds: Mollys Pond, Cabot Township (4PG); Nelson Pond, Woodbury and Calais Townships (4PG) ; Niggerhead Pond, Marshfield Township (4PG); Peacham Pond, Peacham Township (4PG); Wheelock Pond, Calais Township (4PG). Contour interval, 5 and 10 feet. Topography to 10 feet. Published in Water-Supply Paper 424.

(c) Mad River from mouth to Mill Brook, 1 mile from Waitsfield, 15 miles (4PG). Plan by United States Geological Survey in cooperation with State of Vermont, 1910. Scale, 1:24,000. Contour interval 10 feet on land, 1 foot on water. Published in Water-Supply Paper 424.

(c) Waterbury River from mouth upstream 11 miles (4PG). Plan by United States Geological Survey in cooperation with State of Vermont, 1910. Scale 1:24,000. Contour interval, 10 feet on land, 1 foot on water. Topography to 20-30 feet. Published in Water-Supply Paper 424.

(c) Huntington River from mouth to Richmond electric-light plant, 2 miles (4PG). Plan by United States Geological Survey in cooperation with State of Vermont, 1910. Scale, 1:24,000. Contour interval, 10 feet on land, 1 foot on water. Topography to 10-50 feet. Published in Water-Supply Paper 424.

ConNeCTICUT RIVER (1G).

(a) Passumpsic River from mouth to Center Pond, Vt., 38 miles (1GC), and tributaries. Plan and profile, 1928. Scale, 1:24,000. Contour interval, 10 feet. Topography detailed. Published in three sheets (two plan, one profile), 1929.

(b) West Branch of Passumpsic River from mouth to West Burke, 8 miles (1GC). Plan and profile, 1928. Scale, 1:24,000. Contour interval, 10 feet. Topography detailed. Shown on parts of two sheets in set of four, 1928 survey of Passumpsic River and tributaries. 
(c) Calendar Brook from mouth upstream 21/2 miles (1GC). Plan and profile, 1928. Seale, 1:24,000. Contour interval, 10 feet. Topography detailed. Shown on parts of two sheets in set of four, 1928 survey of Passumpsic River and tributaries.

(b) Millers Run from mouth to Sheffield, 10 miles (1GC). Plan and profile, 1928. Scale, 1:24,000. Contour interval, 10 feet. Topography detailed. Shown on parts of two sheets in set of four, 1928 survey of Passumpsic River and tributaries.

(b) Moose River from mouth to Victory, 17 miles (1GC). Plan and profile, 1928. Scale, 1:24,000. Contour interval, 10 feet. Topography detailed. Shown on parts of two sheets in set of four, 1928 survey of Passumpsic River and tributaries.

(b) Kirby Brook from mouth upstream 2 miles (1GC). Plan and profile, 1928. Scale, 1:24,000. Contour interval, 10 feet. Topography detailed. Shown on parts of two sheets in set of four, 1928 survey of Passumpsic River and tributaries.

(c) Knapp Brook from mouth upstream 11/2 miles (1GC). Plan and profile, 1928. Scale, $1: 24,000$. Contour interval, 10 feet. Topography detailed. Shown on parts of two sheets in set of four, 1928 survey of Passumpsic River and tributaries.

(b) Sleepers River from mouth upstream 5 miles (1GO). Plan and profile, 1928. Scale, 1:24,000. Contour interval, 10 feet. Topography detailed. Shown on parts of two sheets in set of four, 1928 survey of Passumpsic River and tributaries.

(a) White River from point 3 miles above West Hartford to Royalton town line, 6 miles (1GS), including First Branch from South Tunbridge to Chelsea. Plan and profile, 1928. Scale, 1:24,000. Contour interval, 10 feet. Topography detailed. Published in one sheet.

(b) First Branch from South Tunbridge to Chelsea, 12 miles (1GS). Plan and profile, 1928. Scale $1: 24,000$. Contour interval, 10 feet. Topography detailed. Shown on one sheet, 1928 survey of White River.

For areas in Vermont covered by United States Geological Survey standard topographic maps see plate 1.

\section{VIRGINIA}

Potomac River from Great Falls upstream to Lock No. 10, 6 miles (1TC). Plan, 1910. Scale, 1:12,000. Contour intervals, 25 feet on land, 5 feet on water. Topography to 125 feet. Published in one sheet. Out of stock.

Pотомac RIver from Chain Bridge to Great Falls, 10 miles (1TC), showing area affected by proposed dam at Chain Bridge. Plan by Corps of Engineers, United States Army, 1920. Scale, 1:27,250. Contour interval, 10 feet. Topography to 100-150 feet. Published in report, Development of Great Falls for water power, by Sixty-sixth Congress, third session, in Senate Document 403.

Great Falls dam site. Scale, 1:10,800. Contour interval, 5 feet.

Potomac RIVer from Aqueduct Bridge to Cumberland, Md., 186 miles (1SB, 1SD, 1SE, 1SF, 1TA, 1TB, 1TC). Profile. Scale, 1 inch $=4$ miles. Published in Water-Supply Paper 192.

Ротомас Rrver from Aqueduct Bridge to Harpers Ferry, 59 miles (1TA, 1TB, 1TC). Profile by Corps of Enginers, United States Army. Scale, 1 inch $=4$ miles. Published in report, Development of Great Falls for water power, by Sixty-sixth Congress, third session, in Senate Document 403.

Dam site, just above mouth of South Branch. Scale, 1:6,600. Contour interval, 5 feet. Topography to 150 feet.

(a) South Fork Shenandoah River (head of Shenandoah River) from Port Republic to Riverton, 101 miles (1SH). Plan and profile, 1899. Scale, 1:63,360. 
Two sheets. Plan not published. Small-scale profile published in Twenty-second Annual Report of the Director, United States Geological Survey, Part IV.

(a) Shenandoah River from Harpers Ferry to Port Republic, 154 miles (1SK, 1.SH). Profile. Scale, 1 inch $=2$ miles. Published in report, Hydrography of Virginia, by Virginia Geological Survey in Geological series Bulletin 3, 1906.

(a) Shenandoah River, reservoïr site. Plan traced from United States Geological Survey topographic maps. Small-scale plan published in report, Development of Great Falls for water power, by Sixty-sixth Congress, thire seasion, in Senate Document 403.

Two dam sites. Lower one 11/2 miles below Bloomery, W. Va. Scale, 1: 6,600; contour interval, 5 feet; topography to 125 feet.

(b) North Fork Shenandoah River, reservoir site. Plan traced from United States Geological Survey topographic maps. Published in report, Development of Great Falls for water power, by Sixty-sixth Congress, third session, in Senate Documents 403.

Dam site, at Brock's Gap. Scale, 1:6,600; contour interval, 5 feet; topography to 225 feet.

JAMEs River from Richmond to Clifton Forge, 230 miles (2AB, 2AD, 2AE, 2AG, 2AH). Profile. Scale, 1 inch $=9$ miles. Published in Nineteenth Annual Report of the Director, United States Geological Survey, Part IV; also published, scale, 1 inch $=6$ miles, in report, Hydrography of Virginia, by Virginia Geological Survey, in Geological series Bulletin 3, 1906.

(a) North River from mouth to Lexington, 20 miles. Profile. Scale, $\mathbf{1}$ inch $=\mathbf{9}$ miles. Published in Nineteenth Annual Report of the Director, United States Geological Survey, Part IV; also published, scale, 1 inch $=6$ miles, in report, Hydrography of Virginia, by Virginia Geological Survey, in Geological series Bulletin 3, 1906.

ROANOKE RIVER from Roanoke, Va., to Weldon, N. C., 202 miles in Virginia, 32 miles in North Carolina $(2 \mathrm{CA}, 2 \mathrm{CB}, 2 \mathrm{CF})$. Plan and profile by United States Geological Survey, 1905. Scale, plan, $1: 24,000$; profile, 1 inch $=2$ miles. No topography. Published in 11 sheets, plan and profile on each, by United States Geological Survey. Section of river in Virginia shown on 10 sheets; section in North Carolina on 1 sheet. Out of stock. Also published, scale, $1 \mathrm{inch}=12$ miles, in report, Hydrography of Virginia, by Virginia Geological Survey, in Geological series Bulletin 3, 1906.

For areas in Virginia covered by United States Geological Survey standard topographic maps see plate 1 .

\section{WASHINGTON}

Columbia River from international boundary to Wenatchee, 283 miles (12E, 12F). Plan and profile by Corps of Engineers, United States Army, 1891. Scale, 1:24,000. Contour interval, 25 feet. Topography to 25-150. Not published.

Columbia Rrver from international boundary to Rock Island Rapids (12E, 12F). Plan, 1930. Scale, 1:31,680. Contour interval, 20 feet on land and 5 feet on water. Topography detailed, 10 sheets. Not published.

Columbra River (12FC). Grande Coulee dam site. Plan, 1920. Scale, 1: 10,700. Contour interval, 10 feet. Topography to 550 feet. Published in report on Columbia Basin project, by Columbia Basin Survey Commission, State of Washington, 1920.

Columara River from Foster Creek to Swakane Creek (12FE, 12FJ). Plan 1944 and 1945. Scale, 1: 24,000. Contour interval, 10 and 20 feet on land, 5 feet on water. Topography to 800 feet above sea level. Published in 11 sheets (9. plan, 2 profile), 1948. 
The following dam sites are surveyed on a scale of $1: 4,800$; contour interval, 10 feet. Topography to 800 feet above sea level.

Chelan dam site at mile 504.

Rocky Reach dam site at mile 476 .

Swakane Creek dam site at mile $\mathbf{4 7 5}$.

Columbia RIVer from Wenatchee to mouth of Snake River (12FM). Plan by Corps of Engineers, United States Army, 1909-10. Scale, 1: 12,000. Contour interval, 10 feet. Topography 0 to 100 feet. Topography evidently sketched. Twenty-one sheets. Not published.

Columbia RIVER from Rock Island Rapids to mouth of Snake River (12FM). Plan by United States Geological Survey and Corps of Engineers, United States Army. Scale, 1:31,680. Contour interval, 20 feet on land, 5 feet on water. Topography, detailed. Five sheets. Not published.

Columbia Rrver from Rock Island dam to Priest Rapids (12FM). Plan and profile, 1944-45. Scale, 1:24,000. Contour interval, 10 feet. Topography to 550 feet above sea level. Published in 11 sheets ( 9 plan, 2 profile), 1948.

Priest Rapids dam site at mile 397.5. Plan, 1945. Scale, $1: 4,800$. Contour interval, 5 feet. Topography to 550 feet above sea level.

Columbia River from Hood River to Quinton, Oreg., 431/2 miles (12MA, 12MG). Plan and profile, 1929. Scale, 1:31,680. Contour interval 10 feet on land, 5 feet on water. Topography to 50 feet. Three sheets ( 2 plan, 1 profile). Not published.

Columbia River from Vancouver to Stella, 50 miles (12NH). Plan, 1929 and 1930. Scale, 1:24,000. Contour interval, 2, 5, 10, and 25 feet. Topography detailed, showing wide adjacent area. Published in three sheets, 1938.

COLUMBIA RIVER has been surveyed from mouth to international boundary by the Corps of Engineers, United States Army. Inquiries should be addressed to the district office, Corps of Engineers, United States Army, Portland, Oreg.

(a) Pend Oreille River (formerly Clark Fork) from international boundary, Washington, to Albany Falls, Idaho, 75 miles (12DN, 12DM). Plan and profile, 1934. Scale, 1:31,680. Contour interval, 20 feet on land, 1 foot and 5 feet on water. Topography detailed. Published in five sheets (three plan, two profile), 1938.

(a) Pend Oreille River (formerly Clark Fork) from Priest River, Idaho, to international boundary, 72 miles in Washington, 7 miles in Idaho (12DM, 12DN). Plan and profile, 1912. Scale, 1:31,680. Contour interval, 25 feet on land, 5 feet on water. Topography to 25-300 feet. Published in Water-Supply Paper 346.

(a) Sheep Creek from mouth to international boundary, sec. 2 , T. 40 N., R. 38 E., 14 miles (12EA), and dam sites. Plan and profile, 1934. Scale, 1:31,680. Contour interval, 20 feet on land, 5 feet on water. Topography detailed. Damsite scale, 1: 4,800; contour interval, 10 feet. Published in two sheets (one plan, showing also dam sites, one profile), 1936.

Dam site No. 1 , at mile 3.9 in sec. 14 , T. 40 N., R. 39 E. Topography to 120 feet.

Dam site No. 2 , at mile 8.3 in sec. 19 , T. 40 N., R. 39 E. Topography to 110 feet.

(a) Hall Creek from mouth upstream to sec. 2, T. 32 N., R. 36 E., 4 miles (12ED). Plan and profile, 1929. Scale, 1:31,680. Contour interval, 20 feet. Topography detailed. Published in one sheet, showing also two dam sites on San Poil River, 1930.

(a) Spokane River from mouth in sec. 25, T. 28 N., R. 35 E., to sec. 10, T. 27 N., R. 39 E., 35 miles (12EK). Plan and profile, 1912. Scale, 1:31,680. Contour 
interval, 25 feet on land, 5 feet on water. Topography to $50-200$ feet. Published in Water-Supply Paper 377.

(a) Spokane River from Spokane, Washington, to Post Falls, Idaho. 291/2 miles (12EJ). Plan and profile by United States Geological Survey in cooperation with Washington State, 1938. Scale, 1:12,000. Contour interval 5 feet on land, 1 foot on water. Topography to 200 feet. Published in four sheets (three plan and one profile), 1943.

(a) San Poil River from south line of sec. 5, T. 30 N., R. 33 E., to sec. 25, T. 34 N., R. 32 E., 27 miles (12FB). Plan and profile by United States Geological Survey in cooperation with Office of Indian Affairs, 1913. Scale, 1:31,680. Contour interval, 10 feet. 'Topograpny detailed. Published in one sheet.

San Poil River, dam sites. Surveyed, 1929. Scale, 1:4,800. Contour interval 10 feet. Published in one sheet, showing also Hall Creek.

Iron Creek dam site, in sec. 30, T. 31 N., R. 33 E. Topography to 200 feet.

Devils Elbow dam site, in sec. 18, T. 32 N., R. 33 E. 'Topography to 200 feet.

(a) Nespelem River from mouth to sec. 36, T. 32 N., R. 30 E., 9 miles (12FC). Plan and profile, 1911, source not known. Scale, 1:31,680. Contour interval, 25 feet. Topography to about 200 feet. Not published.

(a) Okanogan River, mouth upstream 3 miles (12FD). Scale, 1:24,000, contour interval, 10 feet. Published with map of Columbia River.

(a) Okanogan River and Osoyoos Lake, from mouth of Similkameen River to international boundary (12FD). Plan by United States Geological Survey in cooperation with Washington State, 1940. Scale, 1:4,800. Contour interval, 2 feet and 10 feet. Topography of river and immediately adjacent areas from mouth of lake to Similkameen River. Topography to 930 feet above sea level around Osoyoos Lake. Published in four plan sheets, 1947.

(b) Similkameen River from mouth to international boundary, 24 miles (12FD), showing dam sites. Plan and profile, 1934. Scale, 1:31,680. Contour interval, 10 feet on 'and, 5 feet on water. Topography detailed. Dam-site scale, 1:4,800. Contour interval, 10 feet. Published in two sheets (one plan, one profile, showing also dam sites), 1938.

Shankers Bend dam site, at mile 7 in sec. 12 , T. 40 N., R. $26 \mathrm{E}$. Topography to 220 feet.

Dam site at mile 14.4 in sec. 13, T. 40 N., R. 25 E. Topography to 50 feet.

Dam site at mile 15.8 in sec. 26 , T. 40 N., R. 25 E. Topography to 50 feet.

(a) Methow River from mouth in sec. 36, T. 30 N., R. 23 E., to sec. 16, T. 31 N., R. 22 E., 21 miles (12FG). Plan and profile, 1912. Scale, 1:31,680. Contour interval, 25 feet on land, 5 feet on water. Topography to 50-200 feet. Published in Water-Supply Paper 376.

(a) Methow River mouth upstream 3 miles (12FG). Scale, 1:24,000. Contour interval, 20 feet. Topography to 800 feet above sea level. To be published with 1945 survey of Columbia River from Swakane Creek to Foster Creek.

(b) Chewack Creek from junction with Methow River in sec. 2, T. 34 N., R. $21 \mathrm{E}$., to Dog Creek, 31 miles (12FF). Plan and profile, 1934. Scale, 1:31,68U. Contour interval, 20 feet on land, 5 feet on water. Topography, detailed. Published in two sheets (one plan, one profile), 1937.

(b) Chewack Creek from mouth in sec. 2 , T. 34 N., R. 21 E., to sec. 2, T. 35 N., R. 21 E., 7 miles (12FF). Plan and profile, 1912. Scale, 1:31,680. Contour interval, 25 feet on land, 5 feet on water. Topography to 25-50 feet. Published in Water-Supply Paper 376. 
(c) Lake Creek from mouth in sec. 35 , T. 35 N., R. 21 E., to sec. 36 , T. 35 N., R. 21 E., 1 mile (12FF). Plan and profile, 1912. Scale, 1:31,680. Contour interval, 10 feet. Topography to about 100 feet. Published in Water-Supply Paper 376.

(d) Pearrygin Lake, 3 miles (12FF). Plan, 1912. Scale, 1:31,680. Contour interval, 10 feet. Topography to 100 feet. Published in Water-Supply Paper 376.

(a) Stehekin River (head of Chelan River) from mouth in sec. 36, T. 33 N., R. $17 \mathrm{E}$., to Bridge Creek, 17 miles $(12 \mathrm{FH})$. Plan and profile, 1912. Scale, 1:31,680. Contour interval, 25 feet on land, 5 feet on water. Topography to 25-100 feet. Published in Water-Supply Paper 376.

(b) Bridge Creek from mouth upstream 11 mile (12FH). Plan and profile, 1912. Scale, 1:31,680. Contour interval, 25 feet on land, 5 feet on water. Topography to 200 feet. Published in Water-Supply Paper 376.

(a) Chelan River from mouth in sec. 29 , T. 27 N., R. 23 E., to sec. 13, T. 27 N., R. 22 E., 5 miles (12FH). Plan and profile, 1912. Scale, 1:31,680. Contour interval, 25 feet on land, 5 feet on water. Topography to 100 feet. Published in Water-Supply Paper 376.

(b) Railroad Creek from mouth upstream 4 miles (12FH). Plan and profile, 1912. Scale, 1:31,680. Contour interval, 25 and 100 feet on land, 25 feet on water Topography to about 150 feet. Published in Water-Supply Paper 376.

(c) Domke Creek and Domke Lake from mouth to upper end of lake, 3 miles (12FH). Plan and profile, 1912. Scale 1:31,680. Contour interval 5, 10, 25 feet. Topography to about 150 feet. Published in Water-Supply Paper 376.

(a) Entiat River from mouth upstream 3 miles (12FK). Scale, 1:24,000. Contour interval, 20 feet. Published with 1945 survey of Columbia River.

(a) Wenatchee River and Wenatchee Lake from mouth in sec. 27, T. 23 N., R. 20 E., to Lake Creek, 74 miles (12FL). Plan and profile, 1911. Scale, 1:31,680. Contour interval, 25 feet on land, 5 feet on water. Topography to 25-150 feet. Published in Water-Supply Papers 368 and 486.

(b) White River from mouth in sec. 14, T. 27 N., R. 16 E., to Indian Creek, 20 miles (12FL). Plan and profi!e, 1911. Scale, 1:31,680. Contour interval, 10 feet for $151 / 2$ miles above mouth, 25 feet on land and 5 feet on water for remaining distance. Topography to about 100 feet. Published in Water-Supply Papers 368 and 486.

(c) North Fork White River from mouth upstream 1 mile (12FL). Plan and profile, 1911. Scale, 1:31,680. Contour interval, 10 feet. Topography to 100 feet. Published in Water-Supply Papers 368 and 486.

(b) Nason Creek from mouth in sec. 28 , T. 27 N., R. 17 E., to sec. 8 , T. 26 N., R. 17 E., 6 miles (12FL). Plan and profile; 1911. Scale, 1:31,680. Contour interval, 10 feet. Topography to 50 feet. Published in Water-Supply Papers 368 and 486.

(b) Chiwawa Creek from mouth in sec. 1, T. 26 N., R. 17 E., to point 4 miles above Rock Creek, 27 miles (12FL). Plan and profile, 1911-12. Scale, 1:31,680. Contour interval, 10 feet. Topography to 100 feet. Published in Water-Supply Papers 368 and 486.

(b) Icicle Creek from mouth in sec. 12, T. 24 N., R. 17 E., to point above Jack Creek, 19 miles (12FL). Plan and profile, 1912. Scale, 1:31,680. Contour interval, 25 feet on land, 5 feet on water. Topography to 25-150 feet. Published in Water-Supply Papers 368 and 486.

(a) Keechelus Lake, 4 miles (12FN). Map by United States Geological Survey, 1915 , based on previous survey by United States Bureau of Reclamation. Scale, 1:24,000. Contour interval, 10 feet. Topography to 70 feet. Published in Water-Supply Paper 369. 
(a) Yakima River from sec. 17, T. 12 N., R. 19 E., to sec. 15, T. 21 N., R. 12 E., 103 miles (12FN, 12FP). Plan and profile by United States Bureau of Reclamation and United States Geological Survey. Scale, 1:63,360. No topography. Published in Water-Supply Paper 369.

(b) Kachess Lake, 10 miles (12FN), includes also Little Kachess Lake and area in vicinity of outlet of lake. Map by United States Geological Survey, 1915, based on previous survey by United States Bureau of Reclamation. Scale, 1:24,000. Contour interval, 10 feet. Topography to 30 feet. Published in Water-Supply Paper 369.

(b) Cle Elum River from mouth in sec. 32, T. 20 N., R. 15 E., to Hyas Lake, 37 miles (12FN), including North Fork. Plan and profile, 1911. Scale, 1:31,680. Contour interval, 5, 10, 25 feet. Topography to 25-75 feet. Published in WaterSupply Paper 369 .

(c) Middle Fork Cle Elum River from mouth in sec. 4, T. 22 N., R. 14 E., to Waptus Lake, 10 miles (12FN). Plan and profile, 1911. Scale, 1:31,680. Contour interval, 5, 10, 25 feet. Topography to about 75 feet. Published in WaterSupply Paper 369 .

(d) Waptus Lake, Middle Fork Cle Elum River (12FN). Plan, 1911. Scale, $1: 31,680$. Contour interval, 10 feet. Topography to 60 feet. Published in Water-Supply Paper 369.

(c) West Fork Cle Elum River from mouth in sec. 16, T. 22 N., R. 14 E., upstream 9 miles (12F''). Plan and profile, 1911. Scale, 1:31,680. Contour interval, 5, 10, 25 feet. Topography to 75 feet. Published in Water-Supply Paper 369.

(c) Cle Elum Lake, 4 miles (12FN). Map by United States Geological Survey, 1915, based on previous survey by United States Bureau of Reclamation. Scale, 1:24,000. Contour interval, 10 feet. Topography to about 100 feet. Published in Water-Supply Paper 369.

(b) Naches River from sec. 35, T. 15 N., R. 16 E., to point above Bumping River, 38 miles (12FO). Plan and profile, 1910. Scale, 1:31,680. Contour interval, 25 feet on land, 5 feet on water. Topography to about 100 feet. Published in Water-Supply Paper 369.

(c) Bumping River from mouth to Bumping Lake, 16 miles (12FO). Plan and profile, 1910. Scale, 1:31,680. Contour interval, 25 feet on land, 5 feet on water. Topography to about 100 feet. Published in Water-Supply Paper 369.

(d) Bumping Lake, 3 miles (12FO). Map by United States Geological Survey, 1915, based on previous survey by United States Bureau of Reclamation. Scale, 1:24,000. Contour interval, 10 feet. Topography to 100 feet. Published in Water-Supply Paper 369.

(d.) American River from mouth to Copper Creek, 11 miles (12FO). Plan and profile, 1910. Scale, 1:31,680. Contour interval, 25 feet on land, 5 feet on water. Topography to 100 feet. Published in Water-Supply Paper 369.

(c) Tieton River from mouth in sec. 35, T. 15 N., R. 16 E., to sec. 6, T. 13 N., R. 14 E., 22 miles (12FO). Plan and profile, 1911. Scale, 1:31,680. Contour interval, 25 feet on land, 5 feet on water. Topography to 100 feet. Published in Water-Supply Paper 369.

(a) Tieton River, McAllister Meadows reservoir site (12FO). Map compiled by United States Geological Survey from previous surveys by United States Bureau of Reclamation, 1915. Published in Water-Supply Paper 369.

Dam site, in sec. 31, T. 14 N., R. 14 E. Scale, 1:24,000. Contour interval, 10 feet. Topography to 100 feet at dam site.

(a) Snake River from Lewiston, Idaho, to Washington-Oregon State line, 37 miles (12HR, 12HN). Plan and profile by United States Geological Survey, 1920. 
Scale, $1: 31,680$. Contour interval, 25 feet on land, 5 feet on water. Topography to 25-300 feet. Shown on part of 1920 survey of Snake River from Lewiston, Idaho, to Huntington, Oreg., 187 miles. See Idaho (p. 37).

(a) Walla Walla River (12MB). See Oregon (p. 88).

(b) Touchet River (12MB).

(c) East Fork Touchet River from confluence with South Fork at Dayton to mile $10(12 \mathrm{MB})$, and dam site. Plan and profile by the United States Geological Survey in cooperation with Washington State, 1941. Scale, 1:24,000. Contour interval, 20 feet. Topography to 150-200 feet. Published in three sheets (two plans, one of which shows dam site, one profile), 1946.

Wolf Creek dam site at Mile 4.1 in sec. 11, T. 9. N., R. 39 .E. Scale, 1:4,800. Contour interval, 5 feet on land, 1 foot on water. Topography to 200 feet.

(d) Wolf Creek from mouth to mile 5 (12MB). Plan and profile by the United States Geological Survey in cooperation with Washington State, 1941. Scale, $1: 24,000$. Contour interval, 20 feet. Topography to 200 feet. Shown on 1941 survey of East Fork Touchet River.

(a) Robinson Creek from mouth to mile 2 (12MB). Plan and profile by the United States Geological Survey in cooperation with Washington State, 1941. Scale, $1: 24,000$. Contour interval, 20 feet. Topography to 200 feet. Shown on 1941 survey of East Fork Touchet River.

(c) South Fork Touchet River from confluence with East Fork to confluence of Green Fork and Burnt Fork, 16/1/2 miles (12MB). Plan and profile by the United States Geological Survey in cooperation with Washington State, 1941. Scale, $1: 24,000$. Contour interval, 20 feet. Topography to 200 feet. Shown on 1941 survey of East Fork of Touchet River.

(a) Klickitat River from mouth in sec. 3, T. 2 N., R. 12 E., to sec. 5, T. 11 N., R. 13 E., 73 miles (12ML). Plan and profile by United States Geological Survey in cooperation with Washington State Geological Survey, 1909. Scale, 1:24,000. Contour interval, 50 feet. Topography to 350-500 feet; none on first 17 miles. Published in Water-Supply Paper 253.

(a) Klickitat River from point 3 miles downstream from Diamond Fork to point 3 miles upstream from Diamond Fork (12ML). Scale, $1: 24,000$. Contour interval 20 feet. Topography detailed. In preparation.

(b) Diamond Fork from mouth upstream 4 miles. Part of Klickitat River survey.

(b) West Fork Klickitat River from mouth in sec. 30, T. 9 N., R. 13 E., to sec. 9, T. 9 N., R. 12 E., 5 miles (12ML). Plan and profile, 1909. Scale, 1: 24,000. Contour interval, 50 feet. Topography to about 100 feet. Published in WaterSupply Paper 253.

(c) Fish Lake Stream from sec. 9 , T. 9 N., R. 12 E., to sec. 5, T. 9 N., R. 12 E., 2 miles (12ML). Plan and profile, 1909. Scale, 1:24,000. Contour interval, 50 feet. Topography to 100 feet. Published in Water-Supply Paper 253.

(b) Big Muddy Creek from mouth in sec. 3, T. 7 N., R. 12 E., upstream 2 miles (12ML). Plan and profile, 1909. Scale, 1:24,000. Contour interval, 50 feet. Topography to 300 feet. Published in Water-Supply Paper 253.

(b) Outlet Creek from mouth in sec. 11, T. 6 N., R. 12 E., to sec. 10, T. 6 N., R. 12 E., 1 mile (12ML). Plan, 1909. Scale, $1: 24,000$. Contour interval, 50 feet. Topography to about 300 feet. Published in Water-Supply Paper 253.

(a) White Salmon River from mouth in sec. 17, T. 3 N., R. 10 E., to T. 7 N., R. 10 E., 32 miles (12MM). Plan and profile by United States Geological Survey in cooperation with Washington State Geological Survey, 1909. Scale, 1:24,000. Contour interval, 20 feet. Topography to 100-200 feet. Published in WaterSupply Paper 253. 
(b) Trout Creek from mouth in sec. 24 , T. 6 N., R. 10 E., to sec. 15, T. 6 N., R. 10 E., 2 miles (12MM). Plan and profile, 1909. Scale, 1:24,000. Contour interval, 20 feet. Topography to 100 feet. Published in Water-Supply Paper 253.

(a) Little White Salmon River from mouth in sec. 35 , T. 3 N., R. 9 E., to sec. 26, T. 4 N., R. 9 E., 8 miles (12MG). Plan and profile by United States Geological Survey in cooperation with Washington State Geological Survey, 1909. Scale, 1:24,000. Contour interval, 100 feet. Topography to 100-1,000 feet. Published in Water-Supply Paper 253.

(a) Salmon Creek, Wash., from a point in sec. 4, T. 3 N., R. 3 E., to a point in sec. 10 , T. 3 N., R. $3 \mathrm{E}$. (12NJ), and dam site. Plan by the United States Geological Survey in cooperation with Washington State, 1943. Scale, 1:24,000. Contour interval, 20 feet. Topography to $\mathbf{5 4 0}$ feet above sea level. Published in one sheet, 1947.

Dam site in sec. 4, T. 3 N., R. 3 E. Scale, 1: 4,800 Contour interval 10 feet. Topography to 550 feet above sea level. Shown on 1943 survey of Salmon Creek.

(a) Lewis River from sec. 24 , T. 6 N., R. 2 E., to the falls, 51 miles (12NJ). Plan and profile by United States Geological Survey in cooperation with Washington State Geological Survey, 1909. Scale, 1:24,000. Contour interval, 20 feet. Topography to 200 feet. Published in Water-Supply Paper 253.

(a) Lewis River from mouth to mile 87 (12NJ), and dam sites. Surveyed by United States Geological Survey in cooperation with Inland Power and Light Company, 1928 and 1935. Scale, 1:31,680. Contour interval, 10 and 20 feet on land, 5 feet on water. Topography detailed. Dam-site scale, 1:4,800, contour interval 10 feet, except as noted. Published in 10 sheets (4 plan, 4 profile, 2 dam sites) by United States Geological Survey, 1939.

Yale dam site at mile 35.5, in sec. 32, T. 6 N., R. 4 E. Topography to 350 feet.

Cougar dam site at mile 45.8 , in sec. 25 , T. 7 N., R. 4 E. Topography to 200 feet.

Devils Backbone dam site, at mile 49.8 in sec. 27,28 , T. 7 N., R. 5 E. Topography to 460 feet.

Eagle Cliff dam site, at mile 61 in sec. 24,25 , T. 7 N., R. 6 E. Topography to 240 feet.

Cascade Gorge dam site, at mile 70.8 (unsurveyed area). Topography to 230 feet.

Quartz Creek dam site, at mile 76.4 (unsurveyed area). Contour interval 5 feet. Topography to 220 feet.

Island Camp dam site, at mile 82.2 (unsurveyed area). Topography to 300 feet.

(b) East Fork Lewis River from mouth to mile 21 in sec. 9, T. 4 N., R. 3 E. (12NJ), showing dam site. Shown on two sheets, 1928-35 survey of Lewis River.

Eddy Rock dam site, at mile 1.3 in sec. 32, T. 5 N., R. 1 E. Scale, $1: 4,800$. Contour interval, 10 feet. Topography to 190 feet.

(b) Muddy River from mouth to sec. 35, T. 8 N., R. 6 E., 7 miles (12NJ). Shown on 2 sheets, 1928-35 survey of Lewis River.

(b) Quartz Creek from mouth to mile 2 (12NJ). Shown on one sheet, 1928-35 survey of Lewis River.

(a) Cowlitz River from sec. 21, T: 12 N., R. 2 E., to sec. 31, T. 14 N., R. 10 E., 77 miles (12NK). Plan and profile by United States Geological Survey in cooperation with Washington State Geologlical Survey, 1910. Scale, 1:31,680. Contour interval, 5 feet. Very little topography. Published in Water-Supply Paper 313. 
(a) Cowlitz River from Kelso to sec. 25 , T. 12 N., R. 6 E., 97 miles (12NK) Surveyed by United States Geological Survey and Corps of Engineers, United Staates Army, 1927, 1935, and 1936. From Kelso to sec. 32, T. 12 N., R. 1 E., river mapped by Corps of Engineers, 1927 ; scale, 1:31,680, enlarged to 1:24,000 for publication in one set with later surveys by United States Geological Survey. Contour interval, 10 and 20 feet on land, 5 feet on water. Topography detailed. Dam-site scale, 1:2,400, except as noted; contour interval, 50 feet, except as noted. Published in 12 sheets ( 7 plan, 1 of which shows dam sites, 5 profile sheets ), 1943.

Mossy Rock dam site, in sec. 8, T. 12 N., R. 3 E. Topography to 340 feet.

Mayfield dam site, in sec. 20,29 , T. 12 N., R. 2 E. Topography to 200 feet.

Cowlitz Falls dam site, in sec. 6, T. 11 N., R. 6 E. Topography to 80 feet.

Shut-in dam site, in sec. 9, T. 12 N., R. 3 E. Scale, 1:4,800. Contour interval, 10 feet. Topography to 380 feet.

(b) Cispus River from sec. 31, T. 12 N., R. 6 E., to point near Lake Creek, 45 miles (12NK). Plan and profile by United States Geological Survey in cooperation with Washington State Geological Survey, 1910-11. Scale 1:31,680. Contour interval, 25 feet on land, 5 feet on water. Topography to 100-300 feet. Published in Water-Supply Paper 313.

$(\delta)$ Cispus River from mouth to East Canyon Creek, 31 miles (12NK). Shown on 1927-36 survey of Cowlitz River.

(c) Lake Creek from mouth to Walupt Lake, 2 miles (12NK). Plan and profile by United States Geological Survey in cooperation with Washington State Geological Survey, 1911. Scale, 1:31,680. Contour interval, 25 feet on land, 5 feet on water. Topography to about 200 feet. Published in Water-Supply Paper 313.

(d) Walupt Lake, 1 mile (12NK). Plan, 1911. Scale, 1:31,680. Contour interval, 25 feet. Topography to 50 feet. Published in Water-Supply Paper 313.

(c) Muddy Fork from mouth upstream 2 miles (12NK). Plan and profile, 1911. Scale, 1:31,680. Contour interval, 25 feet on land, 5 feet on water. Topogiraphy to about 200 feet. Published in Water-Supply Paper 313.

(b) Tilton River from junction with Cowlitz River to Morton, about 15 miles (12NK). Surveyed, 1939. Scale, 1:24,000. Contour interval, 20 feet on land, 5 feet on water. Topography detailed. Shown on 1927-36 survey of Cowlitz River.

(b) Toutle River from sec. 34, T. 10 N., R. 2 W., to Spirit Lake in sec. 15, T. 9 N., R. 5 E., 54 miles (12NK), including North Fork. Plan and profile by United States Geological Survey in cooperation with Washington State Geological Survey, 1909. Scale, 1:24,000. Contour interval, 20 feet. Topography to 20-200 feet. Published in Water-Supply Paper 253.

(b) Toutle River and tributaries from mouth to junction of North Fork and South Fork, 17 miles (12NK), showing also North Fork, South Fork, other tributaries, and dam site. Plan and profile by United States Geological Survey in cooperation with Corps of Engineers, United States Army, 1933-36. Topography detailed. Scale, 1:31,680. Contour interval, 10 and 20 feet on land, 5 feet on water. Published in five sheets (three plan, two profile) by the United States Geological Survey, 1939.

Silver Lake dam site, at mile 16.2 in sec. 19 , T. 10 N., R. 1 E. Scale, 1:4,800. Contour interval, 10 feet. Topography to 200 feet. 
(c) South Fork of Toutle River from see. 29, T. 10 N., R. 1 E., to sec. 28, T. 10 N., R. 1 E., 1 mile (12NK). Plan and profile by United States Geological Survey in cooperation with Washington State Geological Survey, 1909. Scale, 1:24,000. Contour interval, 20 feet. Topography to 20-200 feet. Published in Water-Supply Paper 253.

(c) South Fork Toutle River from mouth to mile 5 (12NK). Shown on one sheet, 1933-36 survey of Toutle River and tributaries.

(c) North Fork Toutle River from mouth to and including Spirit Lake, 41 miles (12NK), showing dam sites. Scale of dam sites, 1:4,800; contour interval, 10 feet. Shown on 1933-36 survey of Toutle River.

Spirit Lake dam site, at mile 55.2 in sec. 15, T. 9 N., R. 5 E. Topography to 60 feet.

Green River dam site, at mile 27.8 in sec. 8 , T. 10 N., R. 2 E. Topography to 200 feet.

(d) Green River to mile 6 (12NK). Shown on 1933-36 survey of Toutle River and tributaries.

(c) Outlet Creek from junction with Toutle River to Silver Lake, about 2 miles (12NK). Shown on 1 sheet, 1933-36 survey of Toutle River and tributaries.

(d) Silver Lake (12NK). Shown on one sheet, 1933-36 survey of Toutle River and tributaries.

CheHalis RIVer from Northern Pacific Railway bridge in sec. 7, T. 13 N., R. 3 W., to highway bridge in sec. 33, T. 13 N., R. 5 W., 20 miles (12OD). Surveyed by United States Geological Survey in cooperation with the State of Washington, 1940. Scale, 1:24,000. Contour interval, 10 feet on land, 5 feet on water. Topography detailed. Published in two sheets (one plan, one profile), 1942.

(a) South Fork Chehalis River from mouth in sec. 21, T. 13 N., R. 4 W., to point in sec. 12, T. 12 N., R. 4 W., 7 miles (12OD). Shown on 1940 survey of Chehalis River.

(a) Skookumchuck River from sec. 11, T. 15 N., R. 1 W., upstream to sec. 13, T. 15 N., R. 1 E., 9 miles (12OD), including also 4 miles on Johnson Creek and 3 miles on Thompson Creek. Surveyed by United States Geological Survey in cooperation with Washington State, 1939. Scale, 1:24,000. Contour interval, 20 feet on land, 5 feet on water. Topography detailed. Published on one sheet with North Fork Newaukum River, 1943.

Bloody Run dam site, on Skookumchuck River at junction with Bloody Run Creek. Scale, 1:4,800. Contour interval, 10 feet. Topography to 250 feet.

(a) Newaukum River (12OD).

(b) North Fork Newaukum River from mouth of Bear Creek upstream to sec. 20, T. 14 N., R. 1 E., 5 miles (12OD). Surveyed by United States Geological Survey in cooperation with State of Washington, 1939. Scale, 1:24,000. Contour interval, 20 feet. Topography detailed. Published on one sheet with Skookumchuck River, 1943.

(a) Satsop River from mouth to forks, 6 miles (12OD), showing also East Fork and West Fork. Plan and profile, 1934. Scale, 1:31,680. Contour interval, 20 feet on land, 5 feet on water. Topography detailed. Published in three sheets, 1937.

(b) West Fork Satsop River from mouth to Canyon Creek, sec. 22, T. 20 N., R. 7 W., 20 miles (12OD). Shown on 1934 survey of Satsop River.

(b) East Fork Satsop River from mouth to sec. 13, T. 20 N., R. 7 W., 19 miles (12OD). Shown on 1934 survey of Satsop River. 
(a) Wynoochee River from mouth in sec. 18 , T. 17 N., R. 7 W., upstream to sec. 24 , T. 23 N., R. 7 W., 57 miles (12OD). Reconnaissance survey. Scale, 1:31,680. Contour interval, 50 feet. One sheet. Not published.

HUMPTUliPs RIVER from point 1 mile above Deep Creek, sec. 15, T. 19 N., R. $11 \mathrm{~W}$., to forks in sec. 2 , T. 20 N., R. $10 \mathrm{~W}$., 17 miles (12OC), showing tributaries and dam sites. Plan and profile, 1934. Scale, 1:31,680. Contour interval, 20 feet on land, 5 feet on water. Topography detailed. Shown on two sheets (one plan, one profile) in set of five (two plan, two profile, one dam sites) covering Humptuilps River and tributaries, 1937.

(a) East Fork Humptulips River from mouth to sec. 33, T. 22 N., R. 8 W., 19 miles $(120 \mathrm{O})$, showing dam sites. Dam-sites scale, $1: 4,800$; contour interval, 10 feet. Shown on three sheets (two plan, one profile), 1934 survey of Humptulips River.

Dam site A-B, at mile 32.7 in sec. 7, T. 21 N., R. 8 W. Topography to 90 feet.

Dam site C-D, at miles 29.5 in sec. 24, T. 21 N., R. 9 W. Topography to 80 feet.

Dam site E-F, at mile 25.0 in sec. 34 , T. 21 N., R. 9 W., and sec. 4, T. 20 N., R. 9 W. Topography to 110 feet.

(a) West Fork Humptulips River from mouth to sec. 1, T. 22 N., R. 9 W., 24 miles (12OC). Shown on three sheets (two plan, one profile), 1934 survey of Humptulips River.

Dam site G-H, at mile 18.8 in sec. 23 , T. 22 N., R. 9 W. Scale, 1: 4,800. contour interval, 10 feet. Topography to 140 feet.

QUinaUlt RIVER from mouth to Rustler River, 54 miles (12OB), showing dam sites. Reconnaissance survey, 1929. Scale, 1. 31,680. Contour interval, 50 feet on land, 5 feet on water. Topography to 50-250 feet. Published in two sheets (one plan showing also dam site, one profile), 1930.

Quinault Lake dam site in sec. 25, T. 23 N., R. 10 W. (120A). Scale, 1:4,800. Contour interval, 10 feet. Topography to 60 feet.

(a) East Fork Quinault River from sec. 26, T. 24 N., R. 8 W., upstream 15 miles (12OB)). Plan and profile by United States Geological Survey in cooperation with State of Washington, 1934. Scale, 1:31,680. Contour interval, 20 feet on land, 5 feet on water. Topography detailed. Published in one sheet by United States Geological Survey, 1940.

QUEETS RIVER from ocean to point 2 miles above Saghalie Creek, 52 miles (120A), showing also dam site and Clearwater River. Plan and profile, 1931-33. Scale, 1:31,680. Contour interval, 10 and 20 feet on land, 5 feet on water. Topography detailed. Published in five sheets (three plan, two profile), 1935.

Fisher Rapids dam site, at mile 5 in sec. 36, T. 24 N., R. 13 W. Scale, 1:4,800. Contour interval, 10 feet. Topography to 90 feet.

(a) Clearwater River from mouth to Megordens in sec. 20, T. 25 N., R. 11 W., 21 miles (12OA), showing dam sites. Dam-site scale, 1:4,800; contour interval, 10 feet. Shown on two sheets, 1931-33 survey of Queets River.

Hunt Creek dam site, at mile 8 in sec. 6, T. 24 N., R. 12 W. Topography to 80 feet.

Elkhorn Creek dam site, at mile 10 in sec. 32 , T. 25 N., R. 12 W. Topography to 80 feet.

HoH RIVER from mouth to Glacier Creek, 51 miles (120A), showing other rivers, and dam sites. Plan and profile, 1928. Scale, 1:31,680. Contour interval, 50 feet on land, 5 feet on water. Topography to 100-200 feet. Shown on four sheets in set of five covering Quillayute, Bogachiel, and Hoh Rivers, 1929. 
Oxbow dam site, at mile 18.5 in sec. $27,28,33,34$, T. 27 N., R. 12 W.

Scale, 1:4,800. Contour interval, 10 feet. Topography to 175 feet.

(a) Glacier Creek from mouth to Blue and White Glacier, about 5 miles (120A). Plan and profile, 1928. Scale, 1:31,680. Contour interval, 100 feet on land, 50 feet on water. Topography detailed. Shown on one sheet in set of five. of 1928 survey of Hoh River.

(a) South Fork Hoh River from mouth to point 2 miles above boundary of Mount Olympus National Monument, 17 miles (120A). Plan and profile, 1928. Scale, $1: 31,680$. Contour interval, 50 feet on land, 5 feet on water. Topography to 100-200 feet. Shown on three sheets in set of five, 1928 survey of Hoh River.

QUIILAYUTE RIVER from mouth to junction of Bogachiel and Soleduck Rivers, 6 miles (12OA). Plan and profile, 1928. Scale, 1:31,680. Contour interval, 50 feet on land, 5 feet on water. Very little topography. Shown on two sheets in set of five of 1928 survey of Hoh River. Published, 1929.

(a) Soleduck River from mouth in sec. 20, T. 28 N., R. 14 W., to Seven Lakes Basin, T. 28 N., R. 8 W., 65 miles (12OA), including Lyre River. Plan and profile, 1927. Scale, 1:31,680. Contour interval, 50 feet. Topography detailed. Published in seven sheets (four plan, three profile), 1930.

(b) Nameless Creek from mouth to Lake No. 1, in sec. 19,20 , T. 28 N., R. 8 W., 3 miles (120A). Plan and profile, 1927. Scale, 1:31,680. Contour interval, 50 feet. Topography detailed. Shown on two sheets in set of seven of 1927 survey of Soleduck River.

(b) Canyon Creek from mouth to Deer Lake, 2 miles (120A). Shown on 1927 survey of Soleduck River.

(c) Deer Lake Reservoir site (12OA). Reconnaissance survey; plan, 1927. Shown on one sheet in set of seven of 1927 survey of Soleduck River.

Dam site, in sec. 13, T. 28 N., R. 9 W. Scale, 1:6;000. Contour interval, 10 feet. Topography to 60 feet.

(a) Bogachiel River from mouth to North Fork, 35 miles (120A). Plan and profile, 1928. Scale, $1: 31,680$. Contour interval, 50 feet on land, 5 feet on water. Topography to $100-200$ feet. Shown on two sheets in set of five of 1928 Survey of Hoh River. Published, 1929.

Ozette River. Dam site (120A), just below outlet of Ozette Lake. Plan and cross section, 1928. Published on one sheet in set of five, 1928 survey of Hoh River.

Nylund dam site, in sec. 30, T. 31 N., R. 15 W. Scale, 1:4,800. Contour interval 5 feet. Topography to 35 feet.

(a) Ozette Lake, Wash. (12OA). Map compiled from Bureau of Land Management township plats. Scale 1:63,360. No topography. Not published.

(a) Ozette Lake. Proposed tunnel location from Ozette Lake in sec. 12, T. 30 N., R. 16 W., and sec. 7, 8, 17, and 18, T. 30 N., R. 15 W., to Pacific Ocean. Survey, 1928. Scale, $1: 31,680$. Contour interval, 25 feet. Shown on one sheet in set of five, 1928 Survey of Hoh River.

LYRE RIVER from mouth to, and including, Crescent Lake, 15 miles (12PN). Plan and profile, 1927. Scale, 1:31,680. Contour interval, 50 feet. Topography detailed. Shown on two sheets in set of seven, 1927 survey of Soleduck River.

DUNGENESS RIVER from mouth upstream 25 miles (12PM). Reconnaissance survey, 1926. Scale, 1:31,680. Contour interval, 50 feet. Topography detailed. One sheet. Not published.

Dungeness RIver from a point in sec. 13 , T. 29 N., R. 4 W., to a point in unsurveyed sec. 5, T. 28 N., R. 3 W. (12PM). Plan and profile by the United States Geological Survey in cooperation with Washington State, 1945. Scale, 1:24,000. 
Contour interval, 20 feet. Topography detailed. Published in 1947 in one sheet showing plan and profile.

GREY Wolf RIver from mouth upstream 3 miles (12PM). Plan, 1945, by the United States Geological Survey in cooperation with Washington State. Scale, 1:24,000. Contour interval, 20 feet. Published with 1945 survey of Dungeness River.

Quildene River from mouth to Marmot Pass, 19 miles (12PM). Reconnaissance survey. Plan and profile, 1926. Scale, 1:31,680. Contour interval, 50 feet. Topography detailed. One sheet. Not published.

Dosewaluips RIVER from mouth to Deception Creek, 22 miles (12PM). Plan and profile, 1932. Scale, 1:31,680. Contour interval, 20 feet on land, 5 and 20 feet on water. Topography detailed. Published in two sheets (one plan, showing also dam site, one profle), 1938.

Rocky Brook dam site, about mile 3.2 in sec. 28 , T. 26 N., R. 2 W. Scale,

1:4,800. Contour interval, 10 feet. Topography to 250 feet.

DUCkabUsh River from mouth to mile 18 (12PM). Plan and profile, 1932. Scale, $1: 31,680$. Contour interval, 20 feet land, 5 and 20 feet on water. Topography detailed. Published in one sheet, in 1938.

Hamma Hamma River from mouth to mile 14 (12PM), showing dam site. Plan and profile, 1932 and 1936. Scale, 1:31,680. Contour interval, 20 feet. Topography detailed. Published in two sheets (one plan, showing also dam site, one profile) in 1938 .

Dam site, at mile 3.5 in sec. 16, T. 24 N., R. 3 W. Scale, 1:4,800. Contour interval, 10 feet. Topography to 110 feet.

(a) Jefferson Creek from Hamma Hamma River to Washington Creek, 3 miles (12PM). Plan and profile. Shown as part of 1932-36 survey of Hamma Hamma River.

(a) Lena Creek from Hamma Hamma River to East Fork, 2 miles (12PM). Plan and profile. Shown as part of 1932-36 survey of Hamma Hamma River.

Skokomish River from mouth to sec. 28, T. 23 N., R. 6 W., 33 miles (12PM), including South Fork. Plan and profile, 1925. Scale, 1:31,680. Contour interval, 50 feet. Topography to $200-300$ feet. Not published.

(a) North Fork Skokomish River (head of Skokomish River) from mouth to north line of T. 21 N., R. 4 W., 2 miles, and from Lake Cushman reservoir to south boundary of Olympic National Monument, 10 miles (12PM). Plan and profile, 1925. Scale, 1:31,680. Contour. interval, 50 feet. Topography to 200-300 feet. Not published.

Nisqually River and Nisqually Glacier from State Highway No. 5 erossing to point about 2 miles upstream (12PK), showing also lower end of glacier, immediately adjacent topography, and about $1 / 2$ mile of river below it. Surveyed by United States Geological Survey in cooperation with city of Tacoma, 1936. Scale, 1:4,800. Contour interval, 20 feet. Published in one sheet by United States Geological Survey, 1937.

Nisqually River from sec. 29 , T. 19 N., R. 1 E., to point 2 miles above Paradise River, 81 miles (12PK). Plan and profile by United States Geological Survey in cooperation with Washington State Geological Survey, 1910. Scale, 1:31,680. Contour interval, 5 and 100 feet. Very little topography. Published in WaterSupply Paper 313.

Puyallup RIver from sec. 6, T. 19 N., R. 5 E., to boundary of Mount Rainier National Park, 34 miles (12PH). Plan and profile by United States Geological Survey in cooperation with Washington State Geological Survey, 1910. Scale, $1: 31,680$. Contour interval, 5 and 100 feet. Topography to 5-500 feet. Published in Water-Supply Paper 313. 
(a) Puget Sound Power Co. canal from sec. 3, T. 16 N., R. 6 E., to sec. 4, T. 17 N., R. 5 E., 9 miles (12PH). Plan and Profile, 1910. Scale, 1:31,680. Contour interval, 5 and 100 feet. Topography to $100-500$ feet. Published in WaterSupply Paper 313.

(a) Carbon River from mouth in sec. 13, T. 19 N., R. 4 E., to Fairfax in sec. 35, T. 18 N., R. 6 E., 17 miles (12PH). Plan and profile by United States Geological Survey in cooperation with Washington State Geological Survey, 1910. Scale, 1: 31,680. Contour interval, 5 and 100 feet. Topography to 100-600 feet. Published in Water-Supply Paper 313.

SkaGIT RIvER from Concrete, in sec. 11, T. 35 N., R. 8 E., to international boundary, 80 miles (12PD, 12PC). Plan and profile, 1915. Scale, 1:31,680. Contour interval, 25 feet on land, 5 feet on water. Topography to 25-200 feet. Published in Water-Supply Paper 419.

SkAGit RIver from mouth to Sedro Woolley, 23 miles (12PD). Plan and profile by Corps of Engineers, United States Army, to accompany preliminary report on flood control. Profile for high and low water. Scale, 1:24,000. Contour interval, 50 feet. Very little topography. Three sheets. Not published.

(a) Carbon River from mouth of South Prairie Creek in sec. 27, T. 19 N., R. 5 E., upstream to point near west boundary of sec. 4 , T. 18 N., R. 6 E., 6 miles (12PH) and from highway bridge located 4 miles downstream from Fairfax to Rainier National Park, and dam sites. Surveyed by United States Geological Survey in cooperation with Washington State, 1939. Scale, 1:24,000. Contour interval, 20 feet. Topography detailed. In preparation.

Dam site in sec. 31 , T. 19 N., R. 6 E. Scale, 1:4,800. Contour interval, 10 feet. Topography to 300 feet. In preparation.

(a) White River from Buckley in sec. 35, T. 20 N., R. 6 E., to Inner Fork, 53 miles (12PJ). Plan and profile by United States Geological Survey in cooperation with Washington State Geological Survey, 1910. Scale, 1:31,680. Contour interval, 2 and 25 feet. Topography to 25-100 feet. Published in Water-Supply Paper 313.

DUWAMISH RIVER (12PG).

(a) Green River from sec. 18, T. 20 N., R. 11 E., to sec. 35, T. 20 N., R. 11 E., 6 miles and from sec. 10, T. 21 N., R. 7 E., to sec. 7, T. 20 N., R. 9 E., 9 miles (12PG), and dam sites. Plan by United States Geological Survey in cooperation with Washington State and city of Tacoma, 1940-43. Scale, 1:24,000. Contour interval, 20 feet on land, 5 feet on water. Topography detailed. Published in two sheets, 1947.

Weston Dam Site in sec. 28 , T. 20 N., R. 11 E. Scale 1:4,800. Contour interval, 10 feet on land, 1 foot on water surface. Topography to 200 feet. Eagle Gorge Dam Site. Scale, 1:4,800. Contour interval, 20 feet on land, 5 feet on water surface. Topography to 200 feet.

(a) Green River from sec. 26 , T. 21 N., R. 6 E., to sec. 22 , T. 20 N., R. 10 E., 34 miles (12PG). Plan and profile. Scale, 1:96,000. Contour interval, 100 feet. Topography to about 300 feet. Published in Water-Supply Paper 313.

(a) Green River from point 4 miles above mouth in sec. 22, T. 21 N., R. 5 E., to mile 9 in sec. 27 , T. 21 N., R. 6 E. (12PG), and dam sites. Plan and profile, 1936. Scale, 1:31,680. Contour interval, 20 feet on-land, 5 feet on water. Topography detailed. Dam-site scale, 1:4,800; contour interval, 10 feet. Published in one sheet, 1937.

Dam site No. 1, about mile 1:2 in sec. 26 , T. 21 N., R. 5 E. Topography to $\mathbf{1 3 0}$ feet.

Dam site No. 2 , about mile 2.5 in sec. 25 , T. 21 N., R. 5 E. Topography to 330 feet. 
(b) Smay Creek from mouth upstream 3.2 miles (12PG). Plan by United States Geological : Survey in cooperation with Washington State and City of Tacoma, 1940-43. Scale, 1:24,000. Contour interval, 20 feet on land, 5 feet on water. Topography to 0-300 feet. Shown on 1940-43 survey of Green River.

(b) North Fork Green River from mouth upstream, 3.5 miles (12PG). Plan by United States Geological Survey in cooperation with Washington State and City of Tacoma, 1940-43. Scale, 1:24,000. Contour interval, 20 feet on land, 5 feet on water. Topography to 100-200 feet. Shown on 1940-43 survey of Green River.

Cedar River from sec. 9, T. 22 N., R. 6 E., to sec. 12, T. 22 N., R. 8 E., 20 miles (12PG), with outline of Cedar Lake and flowage line of proposed reservoir along the 1,612-foot contour. Plan and profile. Scale, 1:96,000. Contour interval, 100 feet. Very little topography. Published in Water-Supply Paper 313.

SNoнomish RTVER (12PF).

(a) Skykomish River from sec. 6, T. 27 N., R. 9 E., to sec. 31, T. 26 N., R. 12 E., 29 miles (12PF), including South Fork. Plan and profile, 1913. Scale, 1:31,680. Contour interval, 25 feet on land, 5 feet on water. Very little topography. Published in Water-Supply Paper 366.

(b) Foss River from mouth in sec. 31, T. 26 N., R. 12 E., to Trout Lake, 8 miles (12PF), including West Fork. Plan and profile, 1913. Scale, 1:31,680. Contour interval, 25 feet on land, 5 feet on water. Topography to 25-100 feet. Published in Water-Supply Paper 366.

(c) East Fork Foss River from mouth to Alturas Lake, 3 miles (12PF). Plan and profile, 1913. Scale, 1:31,680. Contour interval, 25 feet on land, 5 feet on water. Topography to 25-100 feet. Published in Water-Supply Paper 366.

(b) Miller Creek from mouth in sec. 28, T. 26 N., R. 11 E., to Lake Dorothy, 12 miles (12PF), including East Fork. Plan and profile, 1913. Scale, 1:31,680. Contour interval, 25 feet on land, 5 feet on water. Topography to 50-100 feet. Published in Water-Supply Paper 366.

(c) West Fork Miller Creek from month upstream 2 miles (12PF). Plan and profile, 1913. Contour interval, 25 feet on land, 5 feet on water. Topography to 100 feet. Published in Water-Supply Paper 366.

(b) North Fork Skykomish River from mouth in sec. 19, T. 27 N., R. 10 E., to Troublesome Creek, in T. 28 N., R. 11 E., 12 miles (12PF'). Plan and profile, 1913. Scale, 1:31,680. Contour interval, 25 feet on land, 5 feet on water. Very little topography shown. Published in Water-Supply Paper 366.

(b) Sultan River from mouth to sec. 25, T. 29 N., R. 9 E., 23 miles (12PF). Surveyed from mouth to dam site in sec. 29 , T. 29 N., R. 9 E., by the United States Geological Survey in cooperation with Washington State, 1913; and from dam site upstream, showing reservoir site, by Washington Railroad \& Electric Co. Scale of both surveys, 1 : 31,680; contour interval, 10 and 25 feet on land, 5 feet on water. Topography for reservoir site shown to 200 feet at dam site. Very little topography is shown along river below dam site. Published in Water Supply Paper 366.

(c) Williamson Creek in sec. 24, T. 29 N., R. 9 E., 1 mile (12PF). Plan and profile, 1913. Scale, $1: 31,680$. Contour interval, 25 feet on land, 5 feet on water. Topography to 50-100 feet. Published in Water-Supply Paper 366.

(c) South Fork Sultan River from mouth, in sec. 28 , T. 29 N., R. 9 E., to sec. 34, T. 29 N., R. 9 E., 2 miles (12PF). Plan and profile, 1913. Scale, $1: 31,680$. Contour interval, 25 feet on land, 5 feet on water. Topography to 100 feet. Published in Water-Supply Paper 366.

(a) Snoqualmie River from sec. 15, T. 24 N., R. 7 E., to forks, in sec. 33, T. 24 N., R. 8 E., 8 miles (12PF). Plan and profile, 1911. Scale, 1:31,680. Con- 
tour interval, 25 feet on land, 5 feet on water. Topography to 25-600 feet. Published in Water-Supply Paper 366.

(b) North Fork Snoqualmie River from sec. 34, T. 24 N., R. 8 E., to sec. 15, T. 25 N., R. 9 E., 17 miles (12PF). Plan and profile, 1913. Scale, 1:31,680. Contour interval, 25 feet on land, 5 feet on water. Topography to 25-500 feet. Published in Water-Supply Paper 366.

(c) Calligan Creek from mouth, in sec. 31, T. 25 N., R. 9 E., to sec. 33, T. 25 N., R. 9 E., 3 miles (12PF), including Calligan Lake. Plan and profile, 1913. Scale, 1:31,680. Contour interval, 25 feet on land, 5 feet on water. Topography to about 100 feet. Published in Water-Supply Paper 366.

(c) Hancock Creek from mouth, in sec. 7, T. 24 N., R. 9 E., to sec. 15, T. 24 N., R. 9 E., 3 miles (12PF), including Hancock Lake. Plan and profile, 1911. Scale 1:31,680. Contour interval, 25 feet on land, 5 feet on water. Topography to 200-500 feet. Published in Water-Supply Paper 366 .

(b) Middle Fork Snoqualmie River from sec. 34, T. 24 N., R. 8 E., to sec. 22, T. 24 N., R. 10 E., 20 miles (12PF). Plan and profile, 1913. Scale, 1: 31,680. Contour interval, 25 feet on land, 5 feet on water. Very little topography. Published in Water-Supply Paper 366.

(b) South Fork Snoqualmie River from sec. 33, T. 24 N., R. 8 E., to sec. 8 , T. 22 N., R. 10 E., 19 miles (12PF). Plan and profile, 1911. Scale, 1:31,680. Contour interval, 25 feet on land, 5 feet on water. Topography to 25-300 feet. Published in Water-Supply Paper 366.

(b) Tokul Creek from mouth, in sec. 19 , T. 24 N., R. 8 E., to sec. 9 , T. 24 N., R. 8 E., 3 miles (12PF). Plan and profile, 1911. Scale, 1:31,680. Contour interval, 25 feet on land, 5 feet on water. Topography to 150-500 feet. Published in Water-Supply Paper 366.

(b) Tokul Creek from sec. 22, T. 25 N., R. 8 E., to mouth, about 3 miles (12PF), and dam site. Surveyed by United States Geological Survey, State of Washington and city of Seattle, 1939. Scale, 1:31,680. Contour interval, 20 feet on land and water. Topography detailed. Published on one sheet of 1937-38 Tolt River survey.

Tokul Creek dam site, sec. 21, 22, T. 25 N., R. 8 E. Scale, $1: 4,800$. Contour interval, 10 feet. Topography to 300 feet.

(b) Tolt River, about $1 / 2$ mile, just below junction of North Fork and South Fork (12PF), showing also North Fork, South Fork, and Forks dam site. Surveyed by United States Geological Survey, State of Washington and city of Seattle, 1937-38. Scale, 1:31,680. Contour interval, 20 feet on land and water. Topography detailed. Published in three sheets (two plan, one of which shows dam sites, one profile), 1941.

Forks dam site, just below junction of North Fork and South Fork.

Scale, $1: 4,800$. Contour interval, 10 feet. Topography to 300 feet. Shown on one sheet of 1937-38 Tolt River survey.

(c) North Fork Tolt River from mouth to sec. 10, T. 26 N., R. 9 E., 13 miles (12PF). Surveyed by United States Geological Survey, State of Washington and City of Seattle, 1937-38. Scale, 1:31,680. Contour interval, 20 feet on land and water. Topography detailed. Shown on one sheet of 1937-38 Tolt River Survey.

Dry Creek dam site, at mile 10 in sec. 8 , T. 26 N., R. 9 E. Scale, 1: 4,800.

Contour interval, 10 feet. Topography to 350 feet.

(a) South Fork Tolt River from mouth to sec. 26, T. 26 N., R. 9 E., 13 miles (12PF). Surveyed, 1937-38. Scale, 1:31,680. Contour interval, 20 feet. Topography detailed. Shown on one sheet in set of three of 1937-38 Tolt River survey. 
South Fork dam site, at mile 8.5 in sec. 32 , T. 26 N., R. 9 E. Scale, 1:4,800. Contour interval, 10 feet. Topography to 250 feet. Stilaguamish River (12PE).

(a) South Fork Stilaguamish River from mouth upstream 44 miles to Silverton (12PE). Plan and profile, 1925. Scale, 1:31,680. Contour interval, 25 feet on land, 5 feet on water. Published in two sheets (one plan, one profile).

(a) South Fork Stilaguamish River. Dam sites (12PE). Contour interval, 10 feet. Topography to 200 feet. Published in one sheet, showing Cavanaugh Lake reservoir site and miscellaneous reservoir and dam sites, 1926.

Jordan dam site, in sec. 20, 21, 22, T. 31 N., R. 6 E. Scale, $1: 15,810$.

Robe dam site, in sec. 11, T. 30 N., R. 7 E. Scale, $1: 4,800$.

(b) Canyon Creek (12PE). Proposed diversion of Canyon Creek into South Fork Stilaguamish River, showing 1,100-, 1,125- and 1,150-foot contours from Canyon Creek across divide to Robe reservoir site. Plan, 1925. Scale, 1:31,680. Shown on 1925 survey of Cavanaugh Lake and miscellaneous reservoir and dam sites.

(b) Canyon Creek from sec. 25, T. 31 N., R. 7 E., upstream 2 miles (12PE). Plan and profile, shown on 1925 survey of South Fork Stilaguamish River.

(a) North Fork Stilaguamish River from mouth to sec. 11, T. 32 N., R. 7 E., 19 miles (12PE). Plan and profile, 1925. Scale, 1:31,680. Contour interval, 25 feet on land, 5 feet on water. Topography to 200 feet. Shown on two sheets (one plan, one profile) of 1925 survey of South Fork Stilaguamish River.

Oso dam site, in sec. 25 , T. 32 N., R. 5 E. (12PE). Scale, 1: 15,840. Contour interval, 10 feet. Topography to 225 feet above sea level. Shown on 1925 survey of Cavanaugh Lake and miscellaneous reservoir and dam sites.

(a) Pilchuck Creek (12PE).

(b) Lake Creek from Cavanaugh Lake downstream 2 miles (12PE). Plan and profile, 1925. Scale, 1:15,840. Contour interval, 10 feet. Topography to 1,150 feet above sea level. Shown on 1925 survey of Cavanaugh Lake and miscellaneous reservoir and dam sites.

(a) Cavanaugh Lake, T. 33 N., R. 6 E. (12PE), showing Cavanaugh Lake Reservoir site. Plan, 1925. Scale, 1:31,680. Contour interval, 25 feet. Topography to 135 feet. Shown on one sheet, miscellaneous reservoir and dam sites on North and South Forks Stilaguamish River, published 1926.

Cavanaugh Lake dam site, in sec. 21, 22, T. 35 N., R. 6 E. Scale, 1:15,840. Contour interval, 10 feet. Topography to 200 feet.

Skagit River. Dam sites (12PD). Surveyed, 1936. Scale, 1:4,800. Contour interval, 10 feet. Topography to 250 feet. Published in one sheet showing dam sites only, 1938.

Faber dam site No. 1, in sec. 19, T. 35 N., R. 9 E. Faber dam site No. 2 , in sec. 33 , T. 35 N., R. 9 E.

(a) Beaver Creek from mouth upstream 8 miles (12PC). Plan and profile, 1915. Scale, 1:31,680. Contour interval, 25 feet on land, 5 feet on water. Topography to 150 feet. Published in Water-Supply Paper 419.

(a) Ruby Creek from mouth upstream 2 miles (12PC). Plan, 1915. Scale, $1: 31,680$. Contour interval, 25 feet on land, 5 feet on water. Topography to about 150 feet. Published in Water-Supply Paper 419.

(a) Cascade River from mouth in sec. 18, T. 35 N., R. 11 E., to sec. 34, T. 35 N., R. 12 E., 15 miles (12PC). Plan and profile, 1915. Scale, 1:31,680. Contour interval, 25 feet on land, 5 feet on water. Topography to 25-100 feet. Published in Water-Supply Paper 419.

(a) Sauk River from sec. 35, T. 35 N., R. 9 E., to sec. 9 , T. 30 N., R. 11 E. 41 miles (12PC). Plan and profile, 1915. Scale, 1:31,680. Contour interval, 25 
feet on land, 5 feet on water. Very little topography. Published in WaterSupply Paper 419.

(a) Sauk River from sec. 13, T. 34 N., R. 9 E., to Clear Creek, sec. 31, T. 32 N., R. 10 E., 21 miles (12PC), showing Sauk reservoir site and Suiattle River. Plan and profile, 1936. Scale, 1:24,000. Contour interval, 20 feet on land, 5 feet on water. Topography detailed. Published in four sheets (two plan, one profile, one showing Sauk River dam site), 1938.

Sauk River dam site, mile 1.1 in sec. 19,30, T. 34 N., R. 10 E. Scale, 1:4,800. Contour interval, 10 feet. Topography to 300 feet.

(b) North Fork Sauk River from mouth in sec. 9, T. 30 N., R. 11 E., upstream 3 miles (12PC). Plan and profile, 1915. Scale, 1:31,680. Contour interval, 25 feet on land, 5 feet on water. Topography to $25-75$ feet. Published in WaterSupply Paper 419.

(b) South Fork Sauk River from mouth in sec. 9, T. 30 N., R. 11 E., upstream 3 miles (12PC). Plan and profile by United States Geological Survey, 1915. Scale, 1:31,680. Contour interval, 25 feet on land, 5 feet on water. Topography to 25-50 feet. Published in Water-Supply Paper 419.

(b) Whitechuck River from mouth in sec. 14, T. 31 N., R. 10 E., to Camp Creek, 11 miles (12PC). Plan and profile, 1915. Scale, 1:31,680. Contour interval, 25 feet on land, 5 feet on water. Very little topography. Published in Water-Supply Paper 419.

(b) Suiattle River from mouth in sec. 20, T. 33 N., R. 10 E., to Milk Creek, 33 miles (12PC). Plan and profile, 1915. Scale, 1:31,680. Contour interval, 25 feet on land, 5 feet on water. Very little topography. Published in Water-Supply Paper 419.

(b) Suiattle River from mouth to mile 5, sec. 10, T. 33 N., R. 10 E. (12PC). Shown on two sheets (one plan, one profile), 1936 survey of Sauk River.

(a) Baker River from sec. 11, T 35 N., R. 8 E., to sec. 36 , T. 38 N., R. 9 E., 23 miles (12PD). Plan and profile, 1915. Scale, 1:31,680. Contour interval, 25 feet on land, 5 feet on water. Topography to 100-150 feet. Published in WaterSupply Paper 419.

Nooksack RIVER from Maple Falls in sec. 30, T. 40 N.. R. 6 E., to Ruth Creek, 25 miles (12PB), tributaries and dam sites. Plan and profile, 1931-34. Scale, 1:31,680. Contour interval, 20 feet on land, 5 feet on water. Topography detailed. Published in eight sheets (four plan, three profile, one dam site), in 1936.

NoOKsACK RIVER from mouth to Maple Falls, 53 miles (12PB), tributaries and dam sites. Surveyed by United States Geological Survey in cooperation with Washington State, 1938-39. Scale, 1:24,000. Contour interval, 5 and 10 feet on land, 5 feet on water. Topography detailed, showing wide area adjacent to river. Published in five sheets (three plan, two profile), 1947.

Dam site, at mile 16.4, T. 40 N., R. 8 E. Scale 1: 4,800. Contour interval, 10 feet. Topography to 400 feet. Shown on one sheet of 1931-34 survey.

Deming dam site near Deming in sec. 5, 6, T. 38 N., R. 5 E. (12PB). Surveyed by Corps of Engineers, United States Army, 1939. Scale 1:4,800. Contour interval, 10 feet. Topography to about 200 feet. Not published.

(a) Ruth Creek from mouth to mile 4 (12PB). Shown on two sheets (one plan, one profile), 1931-34 survey of Nooksack River.

(a) Swamp Creek from mouth to Twin Lakes, 5 miles (12PB). Shown on two sheets (one plan, one profile), 1931-34 survey of Nooksack River.

(a) Wells Creek from mouth to mile 5 (12PB). Shown on two sheets (one plan, one profile), 1931-34 survey of.Nooksack River.

Wells Creek dam site, at mile 2.2, T. 39 N., R. 8 E. Scale 1:4,800. Contour interval, 10 feet. Topography to 180 feet. 
(a) Glacier Creek from mouth to mile 5 in sec. 28, T. 39 N., R. 7 E. (12PB). Shown on two sheets (one plan, one profile), 1931-34 survey of Nooksack River.

(a) Canyon Creek from mouth to Falls Creek, 6 miles (12PR). Shown on two sheets (one plan, one profile), 1931-34 survey of Nooksack River.

(a) Middle Fork Nooksack River from sec. 13, T. 38 N., R. 5 E., to mile 12 (12PB). Shown on two sheets (one plan, one profile)', 1931-34 survey of Nooksack River.

(a) Middle Fork Nooksack River from mouth to Heislers Creek, about 5 miles (12PB). Shown on one sheet of 1938-39 survey of Nooksack River.

(a) South Fork Nooksack River from Saxon Bridge in sec. 21, T. 37 N., R. 5 E., to Wanlick Creek in sec. 2, T. 36 N., R. 7 E., 22 miles (12PB). Shown on two sheets (one plan, one profile), 1931-34 survey of Nooksack River.

(a) South Fork Nooksack River from mouth to Saxon Bridge, 12 miles (12PB). Shown on one sheet of 1938-39 survey of Nooksack River.

Edfro Creek dam site, at mile 2.7 in sec. 35 , T. 37 N., R. 5 E. Scale, 1: 4,800. Contour interval, 10 feet on land, 5 feet on water. Topography to 450 feet. Shown on one sheet of 1981-34 survey of Nooksack River.

Fraser River (Canada).

(a) Sumas River from a point in sec. 16, T. 40 N., R. 4 E., to a point in sec. 9 , T. 39 N., R. 4 E. (13). Shown in one sheet of 1938-39 survey of Nooksack River.

For areas in Washington covered by United States Geological Survey standard topographic maps see plate 1 .

\section{WEST VIRGINIA}

Potomac River (1S).

(a) Cacapon River from mouth upstream 25 miles (1SD), Edes Fort reservoir site. Plan by Corps of Engineers, United States Army, 1920. Scale, 1:171,000. Contour interval, 100 feet, with some 20 -foot auxiliary contours. Topography to 200 feet at dam site. Dam site scale, 1:6,600; contour interval, 20 feet. Published in report by Sixty-sixth Congress, third session, in Senate Document 403.

MISSISSIPPI RIVER (3).

(a) Ohio River from Cairo, Ill., to Pittsburgh, Pa., 967 miles (3N, 3M, 3J, 3G, 3E, 3C). Surveyed for navigation by Corps of Engineers, United States Army, at different dates. Maps filed in district offices of Corps of Engineers.

(b) Tygart River (head of Monongahela River) (3B).

(c) Buckhannon River from point 1 mile above Hall, and 8.2 miles above mouth, upstream 20 miles (3BA), reservoir site. Plan and profile developed from United States Geological Survey maps, 1910. Scale, 1:50,000. No topography. Published in report of Flood Commission of Pittsburgh, 1911.

(c) Teter Creek from point 1.2 miles above mouth, upstream $2 \frac{1}{2}$ miles (3BB), reservoir site. Plan and profile developed from United States Geological Survey maps, 1910. Scale, 1:50,000. No topography. Published in report of Flood Commission of Pittsburgh, 1911.

(c) Sandy Creek from point 2.1 miles above mouth, and 3 miles below Claude, upstream 6 miles (3BB), reservoir site. Plan and profile developed from United States Geological Survey maps, 1910. Scale:1:50,000. No topography. Published in report of Flood Commission of Pittsburgh, 1911.

(b) Monongahela River from Pittsburgh, Pa., to West Fork, W. Va., 128 miles (3BD, 3BH, 3BG). Plan and profile by Corps of Engineers, United States Army, 1906-07. Scale, 1:62,500. No topography. Table of elevations on plan sheet. Not published.

(c) Middle Fork River from point 4 miles below Barbour-Randolph County line upstream 8 miles, also a 3-mile section a few miles downstream (3BA), reservoir sites No. 1 and No. 2. Plan and profile developed from United Satates 
Geological Survey maps, 1910. Scale, 1:50,000. No topography. Published in report of Flood Commission of Pittsburgh, 1911.

(c) West Fork River from point 7.4 miles above Clarksburg to Weston, 29 miles (3BC), reservoir site. Plan and profile, 1910. Scale, 1:50,000. No topography. Published in report of Flood Commission of Pittsburgh, 1911.

(c) West Fork River from mouth to Clarksburg, 169 miles (3BC). Plan and profile by Corps of Engineers, United States Army. Scale, 1:25,340. Contour interval, 10 feet. Topography to 50 feet. Seven sheets, plan and profile on each. Not published.

(d) Elk Creek from point 2 miles below Quiet Dell and 6 miles from Clarksburg, upstream 10 miles (3BC), reservoir site. Plan and profile, 1910. Scale, $1: 50,000$. No topography. Published in report of Flood Commission of Pittsburgh, 1911.

(c) Cheat River from point 1 mile above Rowlesburg upstream 20 miles (3BE), reservoir site No. 2. Plan and profile, 1910. Scale, 1:50,000. No topography. Published in report of Flood Commission of Pittsburgh, 1911.

(c) Cheat River from Pennsylvania-IVest Virginia State line upstream 15 miles (3BF), reservoir site No. 1. Plan and profile, 1910. Scale, 1:50,000. No topography. Published in report of Flood Commission of Pittsburgh, 1911.

(d) Shavers Fork, from point 7.4 miles above Parsons, upstream 12 miles (3BE), reservoir sites No. 1 and No. 2. Plan and profile, 1910. Scale, 1:50,000. No topography. Published in report of Flood Commission of Pittsburgh, 1911.

For West Virginia area covered by United States Geological Survey standard topographic maps see plate 1.

\section{WISCONSIN}

Lake Michigan (4C, 4D).

(a) Peshtigo River from Peshtigo in sec. 30, T. 30 N., R. 23 E., to Copper Rapids in sec. 10, T. 35 N., R. 17 E., 82 miles (4CM). Plan and profile, 1906. Scale, 1: 24,000. Contour interval, 5 and 10 feet. Topography to 10-150 feet. Published in Water-Supply Paper 417.

(a) Fox River from mouth to Portage, 163 miles (4DC, 4DG). Profile by Corps of Engineers, United States Army, 1916-1920. Scale, 1 inch $=7.5$ miles. Plan from Lake Winnebago to Portage, 107 miles. Scale, survey 1: 4,800, scale, published map 1: 48,000. Contour interval 1, 2, 5, 10 feet. Topography varies. Published in report on Fox River, Sixty-seventh Congress, second session, House Document 146.

(b) Wolf River from mouth to Shiocton, 71 miles (4DE, 4DF). Profile compiled by Corps of Engineers, United States Army, 1916-1921. Scale, 1 inch $=7.5$ miles. Plan from mouth to Embarrass River, 46 miles. Survey scale 1:4,800, scale, published map 1:48,000. Contour interval, 1, 2, 5, 10 feet. Topography varies. Published in report on Fox River, Sixty-seventh Congress, second session, House Document 146.

MISSISSIPPI RIVER from source to mouth has been surveyed for navigation and flood control by the Mississippi River Commission at different dates and with varying topographic detail. For copies of maps apply to Mississippi River Commission, St. Louis, Mo.

MISSISSIPPI RIVER between Missouri River and Minneapolis. For report by Chief of Engineers, United States Army, see Seventy-second Congress, first session, House Document 137.

(a) St. Croix River from mouth to point 11 miles abpve Danbury, Wis., 131 miles (5CB, 5CC, 5CD). Surveyed by Corps of Engineers, United States Army, and Byllesby Engineering and Management Corporation, 1923, 1926. Scale, 
1:24,000. Contour interval, 5 feet. Very little topography. Published in six plan sheets by United States Geological Survey, 1929.

(a) Chippewa River from Flambeau River to Chippewa Reservoir, 63 miles (5CG). Plan and profile compiled by United States Geological Survey, 1925. Scale, 1:24,000. Contour interval, 5 feet. Topography detailed. Published in five sheets (four plan, one profile), 1929.

(a) Chippewa River from Chippewa Falls in sec. 6, T. 28 N., R. 8 W., to Flambeau in sec. 33, T. 33 N., R. 7 W., 45 miles (5CJ). Plan and profile, 1903. Scale, 1:24,000. Contour interval, 10 feet. Topography to 10-70 feet. Published in Water-Supply Paper 417.

(a) Chippewa River from mouth to Chippewa Falls, 63 miles (5CK, 5CM). Profile, 1903. Scale, 1: 63,360. Published in Water-Supply Paper 417.

(b) Flambeau River from mouth to Turtle River, T. 42 N., R. 2 E., 115 miles (5CH). Plan and profile, 1906. Scale, 1:24,000. Contour interval, 10 feet. Topography to 10-100 feet. Published in Water-Supply Paper 417.

(a) Black River from Black River Falls in sec. 22, T. 21 N., R. 4 W., to point near Owen in sec. 33, T. 29 N., R. 2 W., 63 miles (5CP, 5CR). Plan and profile, 1906. Scale, $1: 24,000$. Contour interval, 10 feet. Topography to about 50 feet. Published in Water-Supply Paper 417.

(a) Wisconsin River from mouth to Portage, 118 miles (5EG, 5EF). Profile by Corps of Engineers, United States Army, 1867. Scale, 1 inch=1/2 mile. Not published.

(a) Wisconsin River from Kilbourn in sec. 14, T. 13 N., R. 6 E., to Tomahawk in sec. 10, T. 34 N., R. 6 E., 194 miles (5EB, 5EC, 5ED, 5EE). Plan and profile, 1906. Scale, 1:24,000. Contour interval, 10 feet. Topography to 10-100 feet. Published in Water-Suply Paper 417.

(b) Eau Claire River from mouth to The Dells in sec. 7, T. 29 N., R. 10 E., 23 miles (5EB). Plan and profile, 1906. Scale, 1:24,000. Contour interval, 5 feet. Topography to about 50 feet. Published in Water-Supply Paper 417.

For areas in Wisconsin covered by United States Geological Survey standard topographic maps see plate 1.

\section{WYOMING}

MISSISSIPPI RIVER BASIN (6).

(a) Missouri River (6).

(b) Yellowstone River $(6 \mathbf{F}, 6 \mathbf{G})$.

(c) Big Horn River $(6 \mathrm{H})$.

(d) Wind River in sec. 20, 28, 29, 33, 34, T. 3 N., R. 1 E. (6HD).

Pilot Butte reservoir site not on any stream, but is a natural depression adjacent to Wind River. Plan by Arnold Co., filed in Carey Act department, Wyoming. Scale of published map, 1:32,000. Contour interval, 10 feet. Topography to 90 feet above bottom of reservoir. Published in report entitled "Wind River Project, Wyoming," Sixty-fourth Congress, Second session, House Document 1767.

(d) Wind River in sec. 17, 20, 29, T. 2 N., R. 2 E. (6HC). Lost Wells reservoir site is not on any creek but is adjacent to Wind River and reservoir would be filled by a canal. Plan by Arnold Co., filed in Carey Act department, Wyoming. Scale of published map, 1:32,000. Contour interval 10 feet. Topography to 40 feet above bottom of reservoir. Published in report entitled "Wind River Project, Wyoming," Sixty-fourth Congress, Second session, House Document 1767.

(e) Dinwoody Creek from sec. 10, T. 5 N.. R. 5 W., to sec. 10, T. 4 N., R. 6 W., 12 miles $(6 \mathrm{HC})$. Plan and profile by Office of Indian Affairs, 1911. Scale, 1: 4,800 . Little topography. Not published. 
(e) Dinwoody Creek from sec. 16, T. 5 N., R. 5 W., to sec. 1, T. 4 N., R. 6 W. $(6 \mathrm{HC})$, Dinwoody Lake reservoir site. Plan by Arnold Co., filed in Carey Act department, Wyoming. Scale of published map, 1:79,200. Contour interval, 10 feet. Topography to 40 feet, at dam sites. Published in report entitled "Wind River Project, Wyoming." Sixty-fourth Congress, second session, in House Document 1767.

(e) Bull Lake Creek from sec. 8, T. 3 N., R. 2 W., upstream 22 miles $(6 \mathrm{HO})$, showing Bull Lake, 3 miles of creek below lake and 13 miles above. Plan and profile by Office of Indian Affairs, 1911. Scale, 1:11,300. Topography shown in places. Not published.

(e) Bull Lake Creek from sec. 30, T. 3 N., R. 2 W., to sec. 6, T. 2 N., R. 3 W. (6HC). Bull Lake reservoir site. Plan by Arnold Co., filed in Carey Act department, Wyoming. Scale of published map, 1:79,200. Contour interval, 10 feet, Topography to 40 feet at dam site. Dam-site scale, 1:32,000; contour interval, 5 feet; topography to 50 feet. Published in report entitled "Wind River Project, Wyoming," Sixty-fourth Congress, second session, House Document 1767.

(e) Little Wind River (or South Fork) from mouth of North Fork to T. 2 S., R. 5 W., 33 miles $(6 \mathrm{HA})$. Plan and profile by Office of Indian Affairs. Scale, 1:4,800. Contour interval, 50 feet. Topography to 50-900 feet. Not published.

( $f$ ) North Fork Little Wind River from mouth in T. 1 S., R. 1 W., upstream 30 miles (6HA). Plan and profile by Office of Indian Affairs, 1911. Scale, 1:4,800. Contour interval, 50 feet. Topography to 50-100 feet. Not published.

$(g)$ Raft Lake (6HA). Small blueprint by Office of Indian Affairs. Scale, 1:9,600. Contour interval, 50 feet. Topography to 200 feet. Not published.

(d) Shoshone River from sec. 34, T. 52 N., R. 103 W., to sec. 7, T. 52 N., R. 102 W., 5 miles (6HL). Shoshone reservoir site. Plan, 1903. Scale, 1: 18,000. Contour interval, 10 feet. Topography detailed. Not published.

(e) Carter Creek from mouth to sec. 34, T. 52 N., R. 103 W., 5 miles ( $6 \mathrm{HL}$ ). Flan shown on 1903 survey of Shoshone reservoir site.

(e) North Fork Shoshone River from mouth in sec. 12, T. 52 N., R. 103 W., to sec. 18, T. 52 N., R. 103 W., 8 miles (6HL). Plan shown on 1903 survey of Shoshone reservoir site.

(c) Powder River from sec. 33, T. 43 S., R. 83 W., to north line of sec. 35, T. 56 N., R. 77 W., Wyoming, 211 miles (6GE). Plan by United States Geological Survey and United States Bureau of Reclamation 1945-46. Scale, 1:24,000. Contour interval 10 feet with occasional 5-foot contours shown by broken lines. Topography detailed. Published by United States Geological Survey in seven sheets, 1947.

(c) Powder River from north line of sec. 35 , T. 56 N., R. 72 W., sixth principal meridian, Wyo., to sec. 19, T. 9 S., R. 48 E., Principal meridian, Mont. (6GE). Moorhead Reservoir site. Plan by United States Geological Survey and United States Bureau of Reclamation, 1947. Scale, 1:12,000. Contour interval 10 feet with occasional 5-foot contours shown by broken lines. Topography detailed. In preparation.

(b) Little Missouri River from the mouth of North Fork in T. 57 N., R. 65 W., sixth principal meridian, to the Wyo.-Mont. line (6JC). This is part of a survey extending to a point below Marmarth, N. Dak. Plan by United States Geological Survey and United States Bureau of Reclamation, 1946-47. Scale, 1:24,000. Contour interval 10 feet. Topography detailed. In preparation.

(b) Platte River (6M).

(b) North Platte River (head of Platte River) from sec. 10, T. 26 N., R. 65 W., Wyoming, to sec. 20 , T. 19 N., R. 48 W., Nebraska, 45 miles in Wyoming and 75 miles in Nebraska (6N) showing North Platte irrigation project. Plan by United States Bureau of Reclamation, 1911. Scale, 1:31,680. Contour interval, 10 and 
20 feet. Topography detailed. Published in five sheets by United States Bureau of Reclamation.

(b) North Platte River from sec. 23 , T. 26 N., R. 84 W., to sec. 9, T. 26 N., R. 84 W. (6NF, 6NG), Pathfinder reservoir site. Plan by United States Bureau of Reclamation, 1910. Scale, 1:63,360. No contours except 5,850-foot, which is reservoir boundary. Part of reservoir within T. 29,30 N., R. $84,85 \mathrm{~W}$., surveyed at scale, $1: 31,680$. Not published.

(c) Encampment River from sec. 1 to sec. 36, T. 14 N., R. 84 W., 6 miles (6ND). Plan, 1923. Scale, 1:51,800. Contour interval, 50 feet. Topography to 50-300 feet. Not published.

(d) Government Creek from mouth in sec. 24, T. 14 N., R. 84 W., upstream 31/2 miles (6ND). Plan, 1923. Scale, 1:51,800. Contour interval, 50 feet. Topograyhy to 50-300 feet. Not published.

(d) North Fork Encampment River from mouth in sec. 12, T. 14 N., R. 84 W., upstream 61/2 miles (6ND). Plan, 1923. Scale, 1:51,800. Contour interval, 50 feet. Topography to $50-300$ feet. Not published.

(c) Sweetwater River (6NG). Before construction of Pathfinder reservoir, Sweetwater River entered North Platte River in sec. 28, T. 29 N., R. 84 W. Old location of river in reservoir shown on map of Pathfinder reservoir, 1910 survey of North Platte River.

(c) Sweetwater River from Pathfinder reservoir in sec. 5, T. 29 N., R. 85 W., to sec. 4, T. 28 N., R. 102 W., 207 miles (6NG). Plan and profile, 1923. Scale, 1:31,680. Contour interval, 50 feet. Topography to 150-300 feet. Dam-site scale, 1: 6,000, except No. 1 as noted, contour interval, 10 feet. Not published.

No. 1 dam site, in sec. $21,28,29$, T. 28 N., R. 100 W. Scale, 1:1,200. Topography to 150 feet.

No. 2 dam site, in sec. 10 , T. 28 N., R. 98 W. Topography to 150 feet.

No. 3 dam site, in sec. 12, T. 29 N., R. 96 W. Topography to 140 feet.

No. 4 dam site, in sec. 31, T. 30 N., R. 91 W. Topography to 220 feet.

No. 5 dam site, in sec. 5,6 , T. 29 N., R. 90 W. Topography to 240 feet.

No. 6 dam site, in sec. 12,13, T. 29 N., R. 89 W. Topography to 140 feet.

(c) Laramie River from sec. 4, T. 23 N., R. 70 W., to Fox Creek, sec. 2, T. 13 N., R. 77 W., 153 miles (6NL, 6NK). Plan and profile, 1934-35. Scale, 1:31,680. Contour interval, 10 and 20 feet on land, 5 and 20 feet on water. Adjacent topography extending 2 miles or more from river channel along much of course is shown. Published in 10 sheets ( 7 plan, 3 profile), 1939.

(c) Laramie River from mouth in sec. 27, T. 26 N., R. 64 W., to sec. 27, T. 26 N., R. 65 W., 7 miles (6NL), part of North Platte irrigation project. Surveyed by United States Bureau of Reclamation, 1911. Scale, 1:31,680. Contour interval, 20 feet. Topography detailed. Shown on one sheet of 1911 survey of North Platte River.

Colorado RIVER (9).

(a) Green River from sec. 13, T. 24 N., R. 112 W., to sec. 20 , T. 35 N., R. 111 W., 98 miles (9AA, 9AD). Plan and profile, 1909. Scale, 1:31,680. No topography. Published in Water-Supply Paper 396.

(a) Green River from State line to town of Green River, 65 miles (9AK, 9AD). Plan and profile by United States Bureau of Reclamation and United States Geological Survey, 1914. Scale, 1:31,680. Contour interval, 20 feet on land, 5 feet on water. Topography to $20-200$ feet. Published in four sheets (two plan, two profile) in set of sixteen (ten plan, six profile) showing Green River from Green River, Utah, to Green River, Wyo., by United States Geological Survey, 1924.

(b) Blacks Fork from mouth upstream, 28 miles (9AH, 9AJ). Plan and profile by United States Geological Survey and United States Bureau of Reclamation, 
1914. Scale, $1: 31,680$. Contour interval, 20 feet on land, 5 feet on water. Topography to 20-140 feet. Shown on parts of two sheets (one plan, one profile) of 1914 survey of Green River.

(b) Yampa River (9C).

(c) Little Snake River (9CC).

(d) Savery Creek from point 4 miles above mouth to sec. 16, T. 15 N., R. 88 W., 27 miles (9CC), and dam sites. Surveyed, 1986. Scale, 1:31,680. Contour interval, 20 feet on land, 5 feet on water. Topography detailed. Dam-site scale, 1: 4,800; contour interval, 10 feet. Published in two sheets (one plan, one dam sites), 1939.

Sandstone dam site, at mile 7.5 in sec. 2, T. 13 N., R. 89 W. Topography to 220 feet.

Savery dam site A, at mile 17.0 in sec. 2 , T. 14 N., R. 89 W. Topography to 180 feet.

Savery dam site B, at mile 16.4 in sec. 2 , T. 14 N., R. 89 W. Topography to 200 feet.

CoIUMBIA RIVER (12).

(a) Snake River and Jackson Lake from sec. 23 , T. 45 N., R. 114 W., to point about 10 miles above Jackson Lake, Wyo., 25 miles (12GA). Plan by United States Bureau of Reclamation, 1909 . Scale, $1: 63,360$. Contour interval, 10 feet. Topography to 50 feet. Not published.

(a) Snake River from Pine Creek, Idaho, to Horse Creek, Wyo., 36 miles in Idaho, 27 miles in Wyoming (12GB, 12GE). Plan and profile, 1931. Scale, $1: 31,680$. Contour interval, 20 feet on land, 5 feet on water. Topography detailed. Dam-site scale, 1:4,800; contour interval, 10 feet. Published in five sheets (three plan, one profile, one dam site), 1932.

Narrow dam site, at mile 40 above Pine Creek, Idaho. Topography to 270 feet.

Blind Canyon dam site, at mile 44.4 above Pine Creek, Idaho. Topography to 180 feet.

Station Creek dam site, at mile 48.3 above Pine Creek, Idaho. Topography to 180 feet.

Bailey Creek dam site, at mile 53.1 above Pine Creek, Idaho. Topography to $\mathbf{1 7 0}$ feet.

Johnny Counts Flat dam site, at mile 59.5 above Pine Creek, Idaho. Topography to 200 feet.

Great Salt Lake (10H).

(a) Bear River, Woodruff Narrows reservoir site, from sec. 31, T. 18 N., R. 120 W., to sec. 31 , T. 17 N., R. 120 W., 7 miles not including river bends (10HB). Plan. Scale, 1:68,500. Contour interval, 15 feet. Topography to 85 feet at dam site. Published in Water-Supply Paper 517.

(a) Bear River in Wyoming and Utah, from point 6 miles north of Cokeville, Wyo., to junction of Stillwater Fork, Utah; total channel length, 178 miles, of which mile 0 to mile 41, and mile 101 to mile 168, are in Wyoming, the remaining 70 miles in Utah $(10 \mathrm{HB})$, showing also tributaries and dam sites. Surveyed, 1934-38. Scale, 1:31,680. Contour interval, 10 and 20 feet on land, 5 feet on water. Topography for wide area adjacent to river. Dam-site scale, 1:4,800; contour interval, 10 feet. Published in 13 sheets 3 of which show dam sites, 1941.

Myers Narrows dam sites at mile 151.2 in sec. 6, T. 13 N., R. 119 W. Topography to 320 feet.

Woodruff Upper dam site, at mile 105.7 in sec 32, T. 18 N., R. 121 W. Topography to 200 feet.

Woodruff Lower dam site, at mile 103.1 in sec. 20 , T. 18 N., R. 121 W. Topography to 150 feet. 
(b) Yellow Creek in Wyoming and Utah, from mouth to mile 24, of which approximately 5 miles (mile 13 to mile 18) is in Utah (10HB). Shown on 1934-38 survey of Bear River.

(c) Coyote Creek to mile 5 (10HB). Shown on 1934-38 survey of Bear River. Coyote Creek dam site, in sec. 26, T. 14 N., R. 121 W. Scale, 1:4,800. Contour interval, 10 feet. 'Topography to 350 feet.

(b) Pleasant Valley Creek to mile 4 (10HB). Shown on 1934-38 survey of Bear River.

Crompton Reservoir dam site, in Pleasant Valley, sec. 9, T. 15 N., R. 120 W. Scale, 1:4,800. Contour interval, 10 feet. Topography to 140 feet. For areas in Wyoming covered by United States Geological Survey standard topographic maps see plate 1. 



\section{INDEX}

A

Alcovy River, Ga

Alder Creek reservoir site, Calif

Allegheny River, $\mathrm{Pa}$. South Fork of , Utah.

American River, CalifMiddle Fork of, Calif.

North Fork of, Calif

South Fork of, Calif.

American River, Wash.

Ammonoosuc River, N. H

Anderson Creek, Idaho.

Androscoggin River, Maine.

Apalachee River, $\mathrm{Ga}$.

Applegate River, Oreg

Ararat River, N. C

Arkansas River, Colo

South Fork of, Colo

Asay Creek, Utah.

Ash Creek, Calif.

Ashley Creek, Utah.

Attean Pond, Maine. ...............................

Aztec Creek, Utah

\section{B}

Backbone Creek, Calif.

Badger Creek, Oreg.

Baker River, Wash.

Baptism River, Minn

Bar Creek, Oreg.

Batten Kill, N. Y.

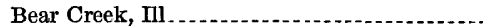

Bear River, Idaho.

Bear River, Utah

East Fork of, Utah

Bear River, Wyo.

Bear Valley Creek, Idaho ....................

Beaver Bay River, Minn

Beaver Creek, Ariz.

Beaver Creek, Colo

East Fork of, Colo

- non

West Fork of, Colo

Beaver Creek, Kans.

Beaver Creek, Oreg.

Beaver Creek, $\mathrm{Pa}$.

Beaver Creek, Utah.

Beaver Creek, Wash

Belmont Creek, Mont

Bennett Creek, Idaho

Big Butte Creek, Oreg

Big Creek, Idaho.

Big Fork River, Minn.

Big Hole River, Mont

Big Houston Pond, Maine
Page
Big Lost River, Idaho North Fork of, Idaho

Big Muddy Creek, Wash..................... 117

Big Muddy River, Ill _......... 49

Big Salmon Creek, Mont..................... 63

Big Salmon Lake, Mont.................... 63

Big Sandy Creek, Ala.......................... 4

Big Sandy River, Ariz.............. 9

Big Spring Creek, Mont_................... 61

Big Wood River, Idaho

Birch River, Minn....... 57

Black Brook, N. Y

Black Butte River, Calif.......... 20

Black Creek, Ariz.......................... 8

Black Creek, Oreg.

Black Lick Creek, Pa.

Black River, Ariz

Black River, N. Y.

Black River, Wis................. 131

Black Warrior River, Ala..................... 4

Blackfoot River, Mont................ 62

Blacks Fork, Wyo............................. 133, 134

Blacksmith Fork, Utah............... 105

Blue River, Colo.............................. 26

Blue River, Oreg

Bog River, N. Y. . .................. 75

Bogachiel River, Wash...................... 122

Bois d'Arc Creek, Tex........... 102

Boise River, Idaho ........................... 39

Middle Fork of, Idaho. ................ 39

North Fork of, Idaho

South Fork of, Idaho

Bonita Creek, Ariz ............... 10

Boreas River, N. Y . . . .

Brady Creek, Tex.

Brandreth Lake Branch, N. Y._........... 75

Brassua Lake, Maine............. $\quad 53$

Brazos River, Tex._......... 100

Breitenbush River, Oreg................... 93

Bridge Creek, Wash........................... 115

Briggs Creek, Oreg................. 83

Bright Angel Creek, Ariz.................. 8

Broad River, Ga........... 31

Middle Fork of, Ga $\mathrm{Ga}_{\ldots} \ldots \ldots \ldots \ldots$

North Fork of, Ga....... 31

Browns Creek, Calif ........................ 22

Brule River, Minn. ............... 56

Buckhannon River, W. Va....... 129

Buckhorn Wash, Utah....................... 109

Buffalo Creek, Pa.......... 96

Buffalo Fork White River, Ark ............. 11

Buffalo River, N. Y...... 74

Buffialo River, Tenn

Bull Lake Creek, Wyo...................... 132

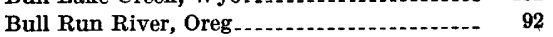


Bullfrog Creek, Utah.
Bumping Lake, Wash.
Bumping River, Wash.
Butler Wash, Utah.
Butte Creek, Calif
Buzzard Creek, Colo

\section{o}

Cacapon River, W. Va

Cache Creek, Calif

Cache La Poudre River, Colo

Cahaba River, Ala

Calapooya Creek, Oreg

Calendar Brook, Vt

Calligan Creek, Wash

Camas Creek, Idaho

Camas Creek, Mont.

Camas Creek, Oreg.

Camp Creek, Oreg.

Canisteo River, N. Y.

Cannon River, Minn

Canyon Creek, Calif

Canyon Creek, Idaho

Canyon Creek, Wash

Cape Fear River, N. C

Carberry Creek, Oreg

Carbon River, Wash

Carrizo Creek, Ariz.

Carson River, Calif

East Fork of, Calif

West Fork of, Calif

Carson River, Nev.

East Fork of, Nev.

West Fork of, Nev

Carter Creek, Wyo.

Cascade River, Minn.

Cascade River, Wash

Casselman River, $\mathrm{Pa}$

Catawba River, N. C

Catherine Creek, Oreg

Cattle Creek, Colo.

Cavanaugh Lake, Wash

Cedar River, N. Y

Cedar River, Wash

Chalk Creek, Colo

Chal': Creek, Utah.

South Fork of, Utah

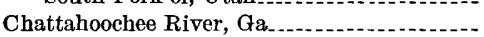

Chattooga River, $\mathrm{Ga}$

Chaugua Creek, S. C

Cheat River, W. Va.

Chehalis River, Wash.

South Fork of, Wash

Chelan River, Wash.

Chemung River, N. Y

Chenango River, N. $Y$

Chestatee River, Ga.

Chewack Creek, Wash.

Chewaucan River, Oreg

Chicago Creek, Colo

Chicopee River, Mass.

Chicorica Creek, N. Mex

Chippewa River, Wis.

Cimarron River, Kans

Cispus River, Wash.
Page

Page

Clackamas River, Oreg................... 94

Clarion River, $\mathrm{Pa}$

Clark Fork, Calif

Clark Fork, Idaho

Clark Fork, Mont

Cle Elum Lake, Wash....................... 116

Cle Elum River, Wash...................... 116

Middle Fork of, Wash................... 116

West Fork of, Wash................... 116

Clear Creek, Calif.......................... 17

Clear Creek, Colo.......... 23, 24

North Fork of, Colo.................... 24

South Fork of, Colo..................... 24

Clear Creek, Idaho_............................ 41

Clear Fork Brazos River, Tex.............. 100

Clear Fork Trinity River, Tex_.......- 100

Clearwater River, Idaho..................... $\quad 45$

Middle Fork of, Idaho.................. 45

North Fork of, Idaho

South Fork of, Idaho

Clearwater River, Mont_..................... 62

Clearwater River, Oreg

Clearwater River, Wash....................... 121

Cleveland Run reservoir site, Kans........... $\quad 50$

Cloquet River, Minn...................... 57

Coeur d' Alene River, Idaho ................. $\quad 37$

North Fork of, Idaho

Cold River, N. Y.

Collawash River, Oreg.

Collier Creek, Oreg. 83

Colorado River, Ariz.............. 5,6

Colorado River, Calif ........ 13

Colorado River, Colo................ 25

Colorado River, Nev..................... 65

Colorado River, Tex.......................... 101

Colorado River, Utah....................... 106

Columbia River, Wash ............. 112, 113

Comb Wash, Utah.............. 110

Connecticut River, Conn.................. 30

Coosa River, Ala............................... 4

Coosawattee River, Ga.................... 34

Cottonwood Creek, Colo....... 25

Cottonwood Creek, Mont.............. 62

Cottonwood Creek, Nev................... 67

Cottonwood Creek, Utah................ 104, 106

Cottonwood Wash, Ariz ................... 8

Cottonwood Wash, Utah............ 110

Coulter Creek, Colo

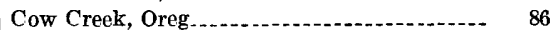

Cowhouse Creek, Tex...................... 101

Cowlitz River, Wash........................ 118, 119

Coyote Creek, Wyo............ 135

Crooked Creek, Pa_..................... 96

Crooked River, Oreg.

Cross River, Minn

Crow Creek, Ill.......... 47

Crow Creek, Mont.

Crow Wing River, Minn........ 58

Crystal River, Colo $\ldots$

Current River, Mo_..... 59,60

Cussawago Creek, $\mathrm{Pa}_{\ldots} \ldots$

Cuthand Creek, Tex. 102

Dead River, Maine

South Branch of, Maine.......... 53 
Page

Deadwood River, Idaho

Deep Creek, Idaho

Deep Creek, Oreg

Deep River, N. C.

Deer Creek, Calif

North Fork of, Calif.

Deer Creek, Idaho.

Deer Creek, Oreg

Deerfield River, Mass.

Delaware, surveys in.

Delaware River, N. Y

West Branch of, N. Y

Deschutes River, Oreg.

East Fork of, Oreg

West Fork of, Oreg.

Devil Creek, Colo

Devil Creek, Idaho

Devil Tract River, Minn.

Diamond Creek, Utah

Diamond Fork, Wash

Dinwoody Creek, Wyo _.................. 131, 132

District of Columbia, surveys of ............

Doe River, Tenn

Dolores River, Colo.

Dolores River, Utah

Dosewallips River, Wash

Dry Creek, Mont..............................

Dry Fork, Utah.

Duchesne River, Utah.

West Fork of, Utah.

Duckabush River, Wash.

Dungeness River, Wash

Dutch Creek, Calif.

Dutcher Creek, Oreg.

Dutton Creek, Calif.

\section{$\mathbf{E}$}

Eagle River, Colo.

East Canyon Creek, Utah

East Fork Coquille River, Oreg ........... 84

East Fork Lake Fork, Utah.

East Fork Touchet River, Wash............ 117

East River, Colo . ...................................

East Sandy Creek, $\mathrm{Pa}$

East Twin Creek, Mont

Eau Claire River, Wis.

Echo Lake reservoir site, Calif..

Eklutna Creek, Alaska

Eklutna Lake, Alaska..

Elk Creek, Calif

Elk Creek, Oreg.

Elk Creek, Tenn

Elk Creek, W. Va

Elkin River, N. C

Embarrass River, Ill North Fork of, Ill

Emigrant Oreek, Oreg

Encampment River, Wyo North Fork of, Wyo

Entiat River, Wash.

Ephraim Creek, Utah.

Escalante River, Utah

Etowah River, $\mathrm{Ga}_{\text {. }}$

Evans Creek, Oreg

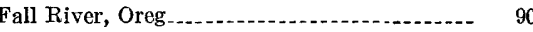

First Branch, Vt ....................... 111

Fish Creek, N. Y........... 73

Fish Creek, Oreg........................... 85, 86

Fish Lake Stream, Wash $\ldots \ldots \ldots \ldots \ldots \ldots \ldots$

Fisher River, N. C...... 76, 77

Fishing Brook, N. Y.

Flagstaff Lake, Maine....................... 53

Flambeau River, Wis.................... 131

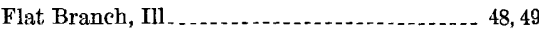

Flathead Lake, Mont . ..................... 62

Flathead River, Mont.............. 62, 63

Middle Fork of, Mont.................... 63

South Fork of, Mont.................... 63

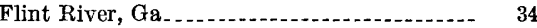

Florida, surveys in.

Fordyce Creek, Calif .

Foss River, Wash. ............. 125

East Fork of, Wash .................... 125

Foster Creek, Oreg

Fourmile Creek, Utah...................... 106

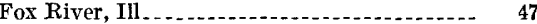

Fox River, Wis.................... 130

Fremont River, Utah . . . . .

French Creek, $\mathrm{Pa}$

North Branch of, $\mathrm{Pa}$. . . .

Frying Pan Creek, Colo................... 26

\section{G}

Gales Creek, Oreg.

Gallinas River, N. Mex.... 70

Gasconade River, Mo_.................... 59

Genesee River, N. Y ......... 74

Geneva Creek, Colo............................. 23

Gerla Creek, Calif.......................... 19

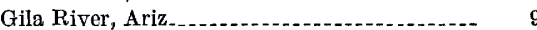

Gila River, N. Mex....................... 70

East Fork of, N. Mex. ............. 70

West Fork of, N. Mex................. 70

Glacier Creek, Wash...................... 122, 129

Gold Creek, Mont.......... 62

Gooseberry River, Minn ................. 57

Gorge Creek, Mont ....................... 63

Government Creek, Wyo_................ 133

Grand Lake, Maine........................ 51

Grande Ronde River, Oreg ............ 88

Grape Creek, Colo _.................... 25

Grave Creek, Oreg .

Green River, Colo

Green River, Utah . . . .

Green River, Wash

North Fork of, Wash................. 125

Green River, Wyo............................ 133

Grey Wolf River, Wash............. 123

Gunnison River, Colo .................... 26,27

H

Hades Creek, Utah......................... 108

Halfmoon Creek, Colo

Hall Creek, Va.

Halls Creek, Utah........................ 106

Hamma Hamma River, Wash............. 123

Hancock Creek, Wash..................... 126

Hanks Creek, Nev . . ........................ 66

Hans Creek, N. Y ...... 73 
Hansen Creek, Utah.
Harpeth River, Tenn
Havasu Creek, Ariz
Hawaii, surveys in
Heenan Creek, Calif
Henrys Fork, Idaho
Henrys Lake, Idaho
Highland Creek, Calif.
Hiwassee River, Ga.
Hiwassee River, N. C.
Hobble Creek, Utah.
Hoh River, Wash.
$\quad$ South Fork of, Wash

Holeb Pond, Maine.

Hood River, Oreg

East Fork of, Oreg.

Middle Fork of, Oreg.

West Fork of, Oreg

Hoosic River, N. Y.

Horse Creek, Oreg

Houston Stream, Maine.

Hudson River, Ga

Hudson River, N. Y.

Humptulips River, Wash.

East Fork of, Wash

West Fork of, Wash.

Huntington Creek, Utah.

Huntington River, Vt.

\section{I}

Icicle Creek, Wash

nllinois River, Ill

Illinois River, Oreg

East Fork of, Oreg

Imnaha River, Oreg.

Creek, Nev

Indigo Creek, Oreg

Jackson Creek, Oreg

James Creek, Colo

James River, Va.

Jefferson Creek, Wash

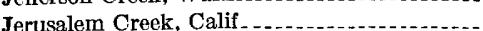

Jessup River, N. Y

Jim Ned Creek, Tex.

John Day River, Oreg

Johnson Creek, Idaho

Josephine Creek, Ore

Judith River, Mont

Jump-off Joe Creek, Oreg

Juniata River, $\mathbf{P a}$

\section{$\mathbf{K}$}

Kachess Lake, Wash

Kaibito Creek, Ariz

Kanab Creek, Ariz

Kane Creek, Utah..

Kankakee River, Ill

Kaskaskia River, IlI

Kawishiwi River, Minn

Keechelus Lake, Wash

Kennebago Lake, Maine

Kennebago River, Maine

Page

Kennebec River, Maine.................. $\quad 52$

Kenyetto Creek, N. Y . . . . .

Keowee River, S. C $\ldots \ldots \ldots$

Kern River, Calif . ........................ 12

South Fork of, Calif. 12

Kickapoo Creek, Ill.

Kings River, Calif........................ 14

Middle Fork of, Calif . ........ 14

South Fork of, Calif.................. 14

Kinzua Creek, $\mathrm{Pa}$

Kirby Brook, Vt $\mathrm{V}_{\ldots} \ldots$

Kirkland Creek, Ariz

Klamath River, Calif $\ldots . . . . . . . . . .21$

Klamath River, Oreg

Klickitat River, Wash

West Fork of, Wash ................. 117

Klondyke Creek, Oreg . ...................... 83

Knapp Brook, Vt $\ldots \ldots \ldots \ldots$

Kootenai River, Idaho _................. 35

Kootenai River, Mont...................... 61

Kunjamuk Creek, N. Y ............. 72

\section{L}

Lake Branch, Oreg-................ 91

Lake Creek, Colo . . . . . . . .

Lake Creek, Oreg

Lake Creek, Wash . . ............ 115, 119, 127

Lake Fork Gunnison River, Colo . ........... 27

Lake Mead, Ariz

La Moine River, Ill . . .

Lampasas River, Tex

Laramie River, Wyo_......................... 133

Last Chance Creek, Utah.

Laurel Hill Creek, Pa. ................... 97

Lawson Creek, Oreg ..................... 83, 84

Lefthand Creek, Colo........................ 24

Lena Creek, Wash. ...................... 123

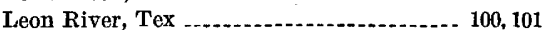

Leroux Wash, Ariz

Lewis Fork, N. C........................ 76

South Fork of, N. C............ 76

West Fork of, N. C................... 76

Lewis River, Wash

East Fork of, Wash . . .

Lick Creek, Ill ............................. 48

Little Bitterroot River, Mont .............. 64

Little Browns Creek, Calif................... 22

Little Butte Creek, Oreg.................... 81

South Fork of, Oreg...................... 81

Little Colorado River, Ar1z.................. $\quad 7,8$

Little Cottonwood Creek, Utah............. 103

Little Fork River, Minu..... ............... 58

Little Humboldt River, Nev .................. 67

North Fork of, Nev...

South Fork of, Nev

Little Kennebago Lake, Maine_............ $\quad 54$

Little Missouri River, Mont ............... 61

Little Missouri River, N. Dak _............ 78

Little Missouri River, S. Dak _.............. 98

Little Missouri River, Wyo. .................. 132

Little River, Ga ....

Little River, S. C. . .

Little Salmon Crouk, Mont............... 63

Little Salmon River, Idaho..................... 44

Little Sandy Creek, $\mathbf{P a} \ldots$

Iittle Smoky Creek, Idaho................... 40 
Little Snake Kiver, Colo

Middle F'ork of, Colo

North Fork of, Colo

Little Spencer Stream, Maine.

Little Tonawanda Creek, N. Y

Little Tupper Lake Branch, N. Y

Little Wabash River, Ill

Little White Salmon River, Wash

Little Wind River, Wyo

North Fork of, Wyo

Lochsa Fork, Idaho.

Logan River, Utah.

Lolo Creek, Idaho

Long Crane Creek, S. C

Long Pond, Maine.

Loon Creek, Idaho

Loon Lake, Oreg.

Lost Creek, Idaho

Lost Creek, Oreg

Lost Creek, Utah

Lower Current Creek, Utah

Lower Red Lake, Minn

Lower Richardson Lake, Maine.

Lower Roach Pond, Maine

Loyalhanna Creek, $\mathrm{Pa}$

Luckiamute River, Oreg

Lyre River, Wash

McCloud River, Calif.

McKenzie River, Oreg..

South Fork of, Oreg.

Mackinaw River, Ill

McNeil Creek, Oreg.

Mad River, N. H.

Mad River, Vt

Madison River, Mont

Mahoning Creek, $\mathrm{Pa}$

Malheur River, Oreg

Middle Fork of, Oreg

North Fork of, Oreg

Manitou River, Minn.

Mann Creek, Idaho

Manti Creek, Utah

Marble Creek, Idaho

Martins Creek, Nev.

Marys River, Nev.

Mattawamkeag River, Maine.

Mayfield Creek, N. Y

Medicine Lodge Creek, Idaho

Methow River, Wash

Metolius River, Oreg

Michigan, surveys in

Middle Boulder Creek, Colo

Middle Concho River, Tex

Middle Fork Eel River, Calif.

Middle Fork Feather River, Calif

Middle Fork River, W. Va.

Middle Fork Willamette River, Oreg

North Fork of, Oreg

Middle Roach Pond, Maine

Middle St. Vrain Creek, Colo

Middle Santiam River, Oreg.

Middle Sulphur River, Tex.

$$
772100-48-10
$$

Page 104 72 21 Mill Creek, Oreg . . . . . . . Mill Creek, Utah ............................. 104 Mille Lacs Lake, Minn ................. . 58 Miller Creek, Wash . . . . . . . . . . 125

West Fork of, Wash $\ldots$

Millers Run, Vt............ 111 Milligan Creek, Nev . . . Minam River, Oreg.................... 88 Minerva Stream, N. Y.................. $\quad 72$ Minnesota River, Minn ................... 58 Mission Creek, Idaho .................... 46 Mission Creek, Mont................... 64 Mississinewa River, Ind ... Mississippi River, Ark ................. 11 Mississippi River, Ill........ 46 Mississippi River, Iowa. ............ 49 Mississippi River, La...................... 50 Mississippi River, Minn . . . . . . . . . . . . . 58 Mississippi River, Miss . . _ _ _ Mississippi River, Mo Mississippi River, Wis . . . _ _ _ _ 130 Missouri River, Iowa Missouri River, Kans _. . . . . Missouri River, Mo . $\ldots \ldots \ldots$ Missouri River, Mont ................... 60 Missouri River, Nebr. . . . . Missouri River, N. Dak ................ 77 Missouri River, S. Dak.................... 98 Mitchell River, N. C Mojave River, Calif .................. 12 Mokelumne River, Calif . . . . . . . . . . 15 Moki Creek, Utah. Molalla River, Oreg ..................... 94 Monongahela River, $\mathrm{Pa} \ldots$ Monongahela River, W. Va_._..._._... 129 Monture Creek, Mont Monument Brook, Maine .................. 51 Moose Pond, Maine Moose River, Maine Moose River, Vt . . . ...................... 111 Moosehead Lake, Maine. . . . . Mooselookmeguntic Lake, Maine. . . ....... 54 Mora River, N. Mex ................... 68 Morrison Creek, Colo . . . . Mosby Creek, Utah................... 109 Moyie River, Idaho ........ 36 Muddy Fork, Wash .................... 119 Muddy River, Nev . . . . . . . . Muddy River, Wash

Mulberry River, Ga..................... 33 Mule Creek, Oreg . . Musselshell River, Mont................. 61

$\mathbf{N}$

Naches River, Wash. .............. 116

Nameless Creek, Wash...................... 122

Napias Creek, Idaho ................ 44

Nashu? River, Mass ......................... 56 North Branch of, Mass ................... 56

South Branch of, Mass ............ 56

Nason Creek, Wash .

Navajo Creek, Ariz 
Navajo River, Colo

Nehalem River, Oreg

Neil Creek, Oreg.

Nespelem River, Wash.

Nevada Creek, Mont.

New Jersey, surveys in.

Niagara River, N. Y.

Nisqually River, Wash.

Nolichucky River, Tenn.

Nooksack River, Wash

Middle Fork of, Wash.

South Fork of, Wash.

North Fork Bosque River, Tex.

North Fork Coauille River, Oreg-

North Fork Humboldt River, Nev.

North Fork Newaukum River, Wash

North Fork North Fork Sun River, Mont... -

North Fork Stilaguamish River, Wash

North Lake, Maine.

North Platte River, Nebr. ......................

North Platte River, Wyo . . . . . ........... 132, 133

North River, Va............. 112

North St. Vrain Creek, Colo . . . ........... 24

North Santiam River, Oreg . . . . .

North Sulphur River, Tex _.............. 102

Notteley River, Ga.............................

Nottely River, N. C...........................

Nueces River, Tex.

o

Obed River, Tenn

O'Brien Creek, Calif.

Ocmulgee River, $\mathrm{Ga}$

Oconee River, $\mathrm{Ga}$

Middle Fork of, $\mathrm{Ga}$

Ogden River, Utah.

Ohio River, Ill.

Ohio River, Ind.

Ohio River, $\mathrm{Ky}$

Ohio River, Ohio

Ohio River, $\mathrm{Pa}$.

Ohio River, W. Va

Okanogan River, Wash.

Oklahoma, surveys in

Oregon Gulch, Calif.

Orofino Creek, Idaho.

Oswegatchie River, N. Y

East Branch of, N. Y

West Branch of, N. Y

Otter Creek, Utah

Ottertail Lake, Minn.

Ottertail River, Minn.

Ouachita River, Ark.

Outlet Creek, Wash.

Owyhee River, Oreg.

rage

30

Ozette Lake, Wash.

Ozette River, Wash.

\section{$\mathbf{P}$}

Pack River, Idaho

Pahranagat Valley, Nev

Paint Creek, Tex

Pamelia Creek, Oreg

Panther Creek, Idaho

Paradox Creek, N. Y

Paria River, Ariz
Passumpic River, Vt $\ldots \ldots \ldots$

West Branch of, vt

Paulina Creek, Oreg

Payette River, Idaho . . . . . . . . . . . . . . . ..... 40

Middle Fork of, Idaho ................ 41

North Fork of, Idaho ................... 4 .

South Fork of, Idaho.................. 40

Payson Creek, Utah...................... 102

Pearl River, Miss ....................... 59

Pearrygin Lake, Wash. . . . . . .

Pecan Bayou, Tex..................... 101

Pecos River, N. Mex

Pemigewasset River, N. H $\ldots$

Pend Oreille Lake, Idaho .... . . . . . . . . . . . . . 36

Pend Oreille River, Idaho .... . . . . . . . . . 36

Pend Oreille River, Wash

Penobscot River, Maine.................... 51

East Branch of, Maine .............. 52

West Branch of, Maine

Peshtigo River, Wis.................. 130

Piedra River, Colo ........................ 29

Pigeon River, Minn

Pilot Creek, Calif ........................ 19

Pine Creek, Idaho

Pine River, N. Mex........................ 71

Piney River, Tenn ......... 99

Piscataquis River, Maine. . . . . . . . . . . . 52

Pistol Creek, Idaho

Pit River, Calif . . . . .

South Fork of, Calif............... 16

Piute Creek, Utah.

6 Pleasant Creek, Utah. . . . .

Pleasant Iake, N. Y . .

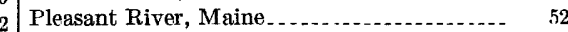

Pleasant Valley Creek, Calif................. 13

Pleasant Valley Creek, Wyo

Pole Creek, Utah

Poorman Creek, Calif . . .

Poplar River, Minn ..................... 56

Post Creek, Mont_............ 64

Potlatch Creek, Idaho

Potomac River, Va

Powder River, Mont. . . . 61

Powder River, W yo . . . . . . .

Prairie River, Minn

Priest River, Idaho

Lower West Fork of, Idaho ............ 37

Provo River, Utah. ..................... 103

North Fork of, Utah.............. 103

South Fork of, Utah................ 103

Puget Sound Power Co. canal, Wash........ 124

Putah Creek, Calif ...................... 20

Puyallup River, Wash .................... 123

\section{Q}

Quaboag River, Mass ....................... 55

Quartz Creek, Wash

Queets River, Wash ...................... 121

Quilcene River, Wash ...................... 123

Quillayute River, Wash................... 122

Quinault River, Wash ....................... 121

East Fork of, Wash................. 121

Quinn River, Nev ........................ 67

\section{$\mathbf{R}$}

Raft Lake, Wyo ........................ 132

Railroad Creek, Wash...................... 115

Rangeley Lake, Maine ..................... 54 
Rapid River, Maine.

Raquette River, N. Y

Raystown Branch Juniata River, Pa.

Red Blanket Creek, Oreg

Red Lake River, Minn.

Red River, La.

Red River, Minn.

Red River, S. Dak

Red River, Tex..

Red River of th

Red Rock River, Mont.

Reese River, Nev

Reeves Creek, Oreg

Relief Creek, Calif

East Fork of, Calif

Republican River, Nebr

Rhode Island, surveys in

Righthand Fork, Utah.

Rio Blanco, Colo

Rio Chama, N. Mex

Rio Grande, N. Mex.

Rio Penasco, N. Mex

Rio Puerco, Ariz

Rio Puerco, N. Mex

Roane Creek, Tenn

Roanoke River, N. C

Roanoke River, Va.

Roaring Fork, Colo

Roaring River, N. C

Robinson Creek, Wash

Rock Creek, Oreg

Rock Creek, Utah

West Fork of, Utah

Rock River, N. Y...

Rogue River, Oreg.

Middle Fork of, Oreg.

South Fork of, Oreg.

Root River, Minn.

Roseau River, Minn

Round Valley Creek, Utah

Row River, Oreg

Rubicon River, Calif.

Little South Fork of, Calif

Ruby Creek, Wash

Ruby River, Mont

Rum River, Minn

Rush Creek, Calif .

Rush Creek, Idaho

Ruth Creek, Wash

\section{S}

Sabine River, Tex

Sacandaga Lake, N. Y.

Sacandaga Reservoir, N. Y

Sacandaga River, N. Y

East Branch of, N. Y.

West Branch of, N. Y

Saco River, Maine

Sacramento River, Calif

St. Croix River, Maine

St. Croix River, Wis

St. Francis River, Maine

St. John River, Maine

Southwest Branch of, Maine..............

St. Lawrence River, N. Y

St. Louis River, Minn

Salado Creek, Tex.
Page 105 Salmon Creek, Oreg. ...................... 92 Salmon Creek, Wash ...................... 118 Salmon River, Calif . North Fork of, Calif................... 21 South Fork of, Calif ................. 21

Salmon River, Idaho ...................... 42, 43 Middle Fork of, Idaho .............. 44 South Fork of, Idaho .............. 44 East Fork of, Idaho .

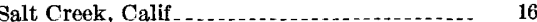

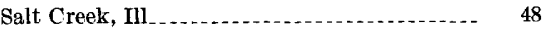
Salt Creek, Oreg . Salt Creek, Utah. ......................... 102 Salt River, Ariz . . ........... 10 Salton Sea, Calif...................... 13 Sandy Creek, W. Va . ................... 129 Sandy River, Maine . . . . . . Sandy River, Oreg . . . . San Francisco River, Ariz ............... 9 San Francisco River, N. Mex.............. 71 Sangamon River, Ill....................... . 47, 48 South Fork of, Ill _.

San Joaquin River, Calif . . . . . . . . . . . . . . 13, 14 North Fork of, Calif................. 14 Middle Fork of, Calif . . . . . . . . 14 South Fork of, Calif $\ldots . . . \ldots \ldots \ldots \ldots$

San Juan River, Colo . . . . . . . . . . . .

San Juan River, N. Mex. . ................. 71

San Juan River, Utah. $\ldots \ldots \ldots \ldots$. $\ldots 9,110$

San Miguel River, Colo . . . _ _............. 27, 28

San Poil River, Wash. ................... 114

San Rafael River, Utah . . .

San Saba River, Tex . _.................... 101

Santa Maria River, Ariz................. 9

Sapinero Creek, Colo

Satsop River, Wash....................... 120

East Fork of, Wash . .

West Fork of, Wash................. 120

Sauk River, Wash...................... 127, 128 North Fork of, Wash . ................. 128

South Fork of, Wash................ 128

Savannah River, Ga...................... 31

Savery Creek, Wyo......... 134

Schoodic Stream, Maine................. 52

Schroon River, N. Y . . . . .

Branch of, N. Y

Scott River, Calif . ....................... 21

Sebec Lake, Ma!ne .

Sebec River, Maine............. 52

Secesh River, Idaho

Selway River, Idaho

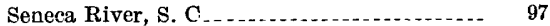

Sevenmile Creek, Utah...... 106

Sevier River, Utah ...................... 105

East Fork of, Utah. ................ 105

Shasta Costa Creek, Oreg . . . . . . . . . . . . . 82,83

Shavers Fork, W. Va................... 130

Sheep Creek, Va.................. 113

Shenandoah River, Va..................... 112

North Fork of, Va. ................. 112

South Fork of, Va................. 111

Shenango River, $\mathrm{Pa} \ldots$

Shinumo Creek, Ariz

Shitike Creek, Oreg.

Shoshone River, Wyo................. 132

North Fork of, Wyo................... 132 
Page

Siletz River, Oreg

North Fork of, Oreg

South Fork of, Oreg

Silver Creek, Calif.

Silver Creek, Idaho

Silver Creek, Oreg

Silver Lake, Maine.

Silver Lake, Wash

Silver Lake reservoir site, Calif ........... 20

Silvies River, Oreg....................... . 78,79

Similkameen River, Wash .................. 114

Sixth Water Creek, Utah ............... 103

'Skagit River, Wash . . . . . . . . . . . . . .... 124,127

Skillet Fork, Ill ........................ 47

Skokomish River, Wash

North Fork of, Wash $\ldots \ldots \ldots \ldots \ldots$

Skookumchuck River, Wash............... 120

Skyhomish River, Wash. .................... 125

North Fork of, Wash .............. 125

Slate River, Colo ......................... 27

Slater Creek, Colo $\ldots \ldots \ldots \ldots \ldots . . .29$

Sleepers River, Vt.......................... 111

Smay Creek, Wash....................... 125

Smith and Morehouse Creek, Utah.......... 104

Smith Creek, Nev........................... 67

Smith Fork, Utah........................ 106

Smoky Creek, Idaho ..................... 40

Snake River, Idaho ...................... 37,38

Snake River, Oreg ................... 87

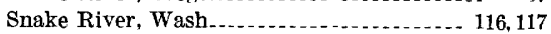

Snake River, Wyo ..................... 134

Snataquin Creek, Utah

Snoqualmie River, Wash $\ldots . . . . . . . . . . .125,126$

Middle Fork of, Wash $\ldots . . . \ldots \ldots \ldots \ldots \ldots . . . . . .126$

North Fork of, Wash ................... 126

South Fork of, Wash .................... $\quad 126$

Soddy Creek, Tenn . . . . . . . . . . . . .

Soldier Creek, Calif . . . . . . . . . . . . . . . 22

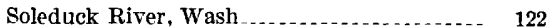

Soque River, Ga.........

Souris River, N. Dak ..................... 78

South Boulder Creek, Colo................... 24

South Branch Moose River, N. Y ........... 74

South Concho River, Tex .................. 101

South Fork Bosque River, Tex ......... 100

South Fork Coquille River, Oreg.........

South Fork Humboldt River, Nev

South Fork River, N. C

South Fork Smith River, Calif .............

South Fork Stilaguamish River, Wash ......

South Fork Touchet River, Wash

South Mahogany Fork Little Cottonwood Creek, Utah.

South Platte River, Colo

North Fork of, Colo

South River, Ga

South St. Vrain Creek, Colo.

South Santiam River, Oreg _............... 93,94

South Sulphur River, Tex ......... 102

South Yamhill River, Oreg ................... 94

Spednik Lake, Maine

Spencer Ponds, Maine

Spencer Stream, Maine................... 53

Spokane River, Wash. .................... 113, 114

Spoon Creek, Ill ................................

Spoon River, Ill ..................................

Spotted Bear River, Mont
Spring Branch, ¿tah................... 108

Spring Creek, Ill . . . . . . . . . . . 48

Spring Creek, Tex....... 101

Spring Lake, Maine....................... 53

Squaw Creek, Calif ....................... 16

Stanislaus River, Calif $\ldots \ldots \ldots \ldots$

Middle Fork of, Calif .......... 15

North Fork of, Calif $\ldots$

South Fork of, Calif $\ldots \ldots \ldots$

Steamboat Creek, Oreg

Stehekin River, Wash ................... 115

Stevens Creek, S. C . . . . . . .

Still Creek, Oreg . . . . .

Stillwater Fork, Utah....................... 105

Stollsteimer Creek, Colo _...

Straight River, Minn ..................... 58

Strawberry River, Utah ................... 108

Strong River, Miss .......................... 59

Stuart Fork Trinity River, Calif. . ........... 23

East Fork of, Calif . . . . . . . . . . . . . . . 23

Sturgeon River, Minn

Sucker Brook, N. Y

Sugar Creek, Ill . .

Suiattle River, Wash........................ 128

Sulphur River, Tex $\ldots \ldots \ldots$

Sultan River, Wash..................... 125

South Fork of, Wash ................ 125

Sumas River, Wash..................... 129

Susquehanna River, N. Y............... 73

Susquehanna River, $\mathrm{Pa} \ldots \ldots \ldots$

West Branch of, $\mathrm{Pa}$

Swamp Creek, Wash. ..................... 128

Swan River, Mont

Sweetwater River, Wyo ................. 133

Swift Creek, Utah $\ldots 108,109$

Swift River, Mass........................... 55

\section{$\mathrm{T}$}

Tallapoosa River, Ala $\ldots . . . . . . . . . . . . . .44$

Tallapoosa River, Ga........................ 34

Tallulah River, Ga........... 31

Tapeats Creek, Ariz $\ldots \ldots \ldots$

Taunton River, Mass . . .

Taylor Creek, Oreg

Taylor River, Colo........................ 27

Temperance River, Minn . . . . . . . . . .

Tennessee Fork, Colo .................... 25

Tennessee River, Ala....................... 4

Tennessee River, Ky ........................ 50

Tennessee River, N. C . ..................... 77

Tennessee River. Tenn .................... 99

Tepee Creek, Idabo

Teter Creek, W. Va

Thirteenth Brook, N. Y ................... 72

Thompson River, Colo $\ldots \ldots \ldots \ldots \ldots . . . . . . . .24$

Tieton River, Wash....................... 116

Tilton River, Wash. . . .

Tionesta River, $\mathrm{Pa}$

Toccoa River, Ga $\ldots$

Tokul Creek, Wash. . . . .

Tolt River, Wash

North Fork of, Wash ............. 126

South Fork of, Wash.................... 126

Tombigbee River, Miss . .................. 59

Toutle River, Wash....................... 119

North Fork of, Wash $\ldots \ldots \ldots$

South Fork of, Wash................... 120 
Towaliga River, Ga

Trachyte Creek, Utah

Trail Creek, Oreg.

Trinity River, Calif

East Fork of, Calif

Trinity River, Tex

West Fork of, Tex

Troublesome Creek, Colo _............ 25, 26 East Fork of, Colo

Trout Brook, N. Y . . . . .

Trout Creek, Wash . . . .

Tugaloo River, Ga $\ldots \ldots \ldots$. 31

Tuolumne River, Calif

Turkey Creek, S. C

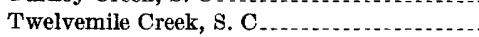

Twin Lakes reservoir site, Calif . ............

Twomile Creek, Utah.

Tyndall Creek, Idaho.....

$\mathrm{U}$

Uinta River, Utah.

Umatilla River, Oreg.

Umbagog Lake, Maine

Umpqua River, Oreg.

North Umpqua River, Oreg

South Umpqua River, Oreg.

Union Creek, Mont.

Union River, Maine

Unnamed Creek, Calif

Upper Red Lake, Minn

Upper Richardson Lake, Maine

Valley Creek, Idaho

Verde River, Ariz.

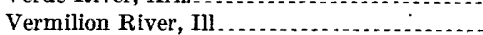

Vermilion River, Minn

Virgin River, Nev.

Vly Creek, N. Y.

Wahweap Creek, Ariz

Wahweap Creek, Utah.

Walla Walla River, Oreg

North Fork of, Oreg.

South Fork of, Oreg

Wallowa River, Oreg.

Walupt Lake, Wash

Waptus Lake, Wash

Ware River, Mass

Warm Creek, Idaho.

Warm Creek, Utah

Warm Spring Creek, Mont

Warm Springs Creek, Idaho.

Warm Springs River, Oreg

Watauga River, Tenn

Waterbury River, Vt.................... 110

Weaver Creek, Calif

South Fork of, Utah

Weiser River, Idaho

East Fork of, Idaho .

Middle Fork of, Idaho

West Fork of, Idaho.

Wells Creek, Wash.

Wenatchee River, Wash. . . . . .

West Camas Creek, Idaho

West Canyon Creek, Ariz ............... 7

West Canyon Creek, Utah.............. 107

West Carry Pond, Maine $\ldots \ldots$

West Fork Lake Fork, Utah _........... 108

West Fork River, W. Va.

West Twin Creek, Mont .................. 62

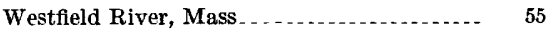

East Branch of, Mass .................. 55

West Branch of, Mass ................ 55

White River, Ariz .................... 10

East Fork of, Ariz ...... 10,11

North Fork of, Ariz . . . . . . . 10

White River, Ark. ............. 11

Buffalo Fork of, Ark................. 11

North Fork of, Ark.................. 12

White River, Mont . . .

White River, Oreg . . . . . . .

White River, Utah . . . . . . . . . . . . . . . . 109

White River, Vt. . . . . . . . . . 111

White River, Wash . . . . . . . . . . . . . . . 115, 124

North Fork of, Wash

White Salmon River, Wash . . . . . . . . . 117

Whitechuck River, Wash $\ldots \ldots \ldots \ldots$

Whiterocks Creek, Utah . . . . . . . . . . . . . 109

Whitewater Creek, Oreg . . . . . . . . . . . . . 93

Wild Rice River, Minn . . ................. 57

Willamina Creek, Oreg .............. 34

Willard Creek, Utah. . . . . . . . . . . 105

Williams Creek, Calif . . .

Williams River, Ariz ............. 8

Williamson Creek, Wash

Willow Creek, N. Mex . . . . . . . .

Wilson Creek, Utah

Wind River, Wyo

Winooski River, Vt. . . . . . . . . ........... 110

Wisconsin River, Wis . . .

Wolf Creek, Calif.

Wolf Creek, Utah. .................... 108

Wolf Creek, Wash

Wolf River, Wis........................... 130

Wood Pond, Maine.

Woods Creek, Calif........................ 14

Wynoochee River, Wash .................. 121

\section{$\mathbf{Y}^{\cdot}$}

Yaak River, Mont ...

Yadkin River, N. C ........................ 76

Yakima River, Wash ...................... 116

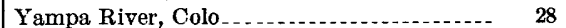

Yellow Creek, Utah.................... 105

Yellow Creek, Wyo........................ 135

Yellow River, Ga......................... 32

Youghiogheny River, Md_.............. 54,55

Youghiogheny River, $\mathrm{Pa} \ldots \ldots \ldots$

Yuba River, Calif ....................... 17

Middle Fork of, Calif............... 18

North Fork of, Calif

South Fork of, Calif ................... 18

\section{$\mathrm{Z}$}

Zealand River, N. H. . . . .

Zigzag River, Oreg ................... 91, 92

Zumbro River, Minn......... 58,59

Zuni River, Ariz . . . . . 8 


